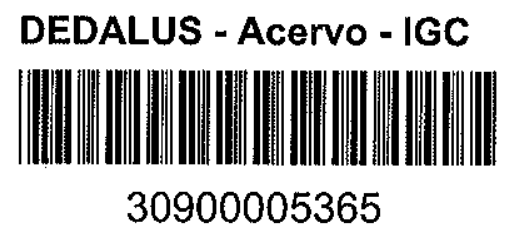

\title{
ALTERAÇÃO INTEMPÉRICA DAS ROCHAS ULTRABÁSICAS DE SANTA FÉ (GO) E GENESE DO DEPÓSITO NIQUELÍFERO
}

Tese de Doutoramento apresentada ao Instituto de Geociências da Universidade de São Paulo.

Orientador :

Prof. Dr. Adolpho José Melfi 
Para a realização deste trabalho, devo ao Prof. Melfi a orientação na escolha do tema e o apoio irrestrito em todas as etapas da investigação. Os conhecimentos cientĩficos por ele transmitidos constituiram para mim aprendizagem essen cial; foram fundamentais tanto para a concepção desta pesquisa, como em todos os momentos do seu desenrolar. Sua afetuosa dedicação e ajuda desinteressada são motivos do meu profundo agradecimento.

A presença constante do Dr. Trescases, sempre a tento ăs minhas dificuldades e paciente com as minhas inquietações, foi fator decisivo na elaboração desta tese. Trabalhando no campo, no laboratōrio e ao microscōpio, discutindo e confrontando idēias, ele me introduziu nas sutilezas do método cientïfico e me desvendou seus mistērios. Por sua extrema generosidade, sinto-me imensamente reconhecida.

Os diretores da Mineradora Montita Ltda. facili taram-me o acesso à ārea e gentilmente cederam os relatōrios da empresa para consulta.

0 Prof. Aledir foi responsāvel pelo meu primeiro contato com a região. Sem seu amāvel apoio, minha inicia ção na ārea teria sido muito mais difícil.

0 trabalho de campo só se tornou possivel graças à empenhada colaboração do Dr. Wackermann na seleção dos perfis mais adequados à amostragem. Devo-lhe tambēm a inestimā vel ajuda nas primeiras interpretações dos dados, que me serviram de guia para o enunciado das principais hipóteses.

0 Sr. Vitor, morador de Santa Fë e funcionärio da Mineradora, cooperou, com incansāvel disposição, na abertura de picadas, na indicação de sĩtios mais favorāveis à cole 
ta de amostras e no seu transporte.

Dna. Melany executou o cuidadoso trabalho de confecção das lāminas delgadas. O Mãrio, a Neide, a Cleide, - Nelson, a Anālia e o Andrē, tēcnicos de laboratōrio do Instituto de Geociēncias, foram muito dedicados na execução dos procedimentos analiticos.

0 levantamento bibliogräfico dependeu da per manente boa vontade da Ruth, da Dulce e da Dna. Antonieta, na localização dos tỉtulos que me interessavam.

Os serviços de datilografia pela claudete, de senho pela Itacy e impressão pelo Sr. Jaime permitiram mate rializar minhas idëias.

As ilustrações fotogräficas, devo-as ao Prof. Marcos Aurēlio, que me ensinou a operar o equipamento apropriado, e ao Jaime, a quem coube a delicada tarefa de revelar e ampliar os negativos.

Quero prestar especial agradecimento ao Prof. Leinz, que, sempre que passava pela minha sala, não deixava de me dizer uma palavra de estimulo e simpatia.

Muitos outros, talvez sem o. saber, contri buiram de alguma forma para o sucesso deste empreendimento. Foram os amigos, meus pais, o Pedro, meus alunos, as crianças e os colegas, que, enriquecendo o universo das minhas relações, tornaram a vida mais gratificante nestes quatro a nos.

0 apoio financeiro, imprescindivel para a realização deste projeto, foi concedido pela Fundação de Amparo ä Pesquisa do Estado de São Paulo e pelo Conselho Na cional do Desenvolvimento Cientifico e Tecnolōgico. 
INDICE

INTRODUÇAOO

CAPITULO I - 0 MEIO FISICO

1. Situação Geogräfica

2. 0 Quadro Geolögico

A. Geologia Regionar 6

B. Geologia Local

C. Caracterização Petrogräfica e Quĩmica das Rochas do Complexo

D. 0 Fenômeno da Serpentinização

3. CTima

A. Pluviosidade

B. Temperatura

C. Evaporação

4. Relevo

A. Aspectos Gerais: compartimentação regional e geo morfogènese

B. Relevo Local: caracterização topogräfica e evolu ção

5. Vegetação

CAPITULO II - ESTUDO MINERALOGICO E GEOQUIMICO DOS PERFIS DE ALTERAÇAO

1. Os Perfis Estudados

A. Topossequências XV e E6 e E10

$B$. Topossequências XXVII e WA

C. Perfis Pe e Py

D. Perfis G e C 
A. Os Fácies de Alteração sobre Dunito

a. 0 perfil completo

b. A composição e a estrutura dos horizontes de alte ração

b. 1. Descrição macroscōpica

b.2. Distribuição granulomëtrica

c. Caracterização mineralōgica dos fäcies de alteração

c.1. Rocha fresca: dunito serpentinizado

c.2. Rocha dura

c.3. Saprolito grosso

c.4. Laterita amarela

c.5. Laterita vermelha

c.6. Materiais ricos em $\mathrm{Ni}$ : um resumo

B. A Alteração do Peridotito e do Piroxenito

a. 0 perfil sobre peridotito

b. 0 perfil sobre piroxenito

C. Distribuição Espacial dos Fäcies de Alteração

D. As Filiações Mineralögicas

3. A Evolução Quĩmica

A. Dados Ponderais

a. A evolução dos dunitos

a.1. Topossequências $X V$ e E6

a.2. Topossequências XXVII, W4 e perfil G

a.2.1. Evolução geral dos elementos químicos durante a a teração

a.2.2. Distribuição dos elementos quimicos nos minerais 
a.2.2.1. Anālises quĩmica dos minerais 104

a.2.2.2. Ataques quimicos parciais 108

a.2.2.3. Anālises quỉmicas das fraçōes granulomētricas 115

b. A evolução das rochas portadoras de piroxênio 118

b.1. Perfis sobre peridotito: Pe e slow4 118

b.2. Perfil sobre piroxenito: Py 121

c. Um perfil extremamente silicificado (perfil c) 123

d. Composição quĩmica da crosta ferruginosa 125

e. Conclusões 126

B. Dados Volumétricos 133

a. Perdas e ganhos no perfil de alteração 133

a.1. Sobre dunito 133

a.2. Sobre peridotito e piroxenito 143

b. Perdas e ganhos na topossequência 149

c. Conclusões 154

CAPITULO III - A EVOLUÇAO GEOQUIMICA AO NIVEL DA PAISAGEM E A GENESE DA JAZIDA DE NIQUEL.

CAPITULO IV - IMPORTANCIA ECONÖMICA DA JAZIDA DE SANTA FE E COMPARAÇAO COM OUTRAS JAZIDAS DO MUNDO

1. A Jazida de Santa Fë

2. Comparação com Outras Jazidas de Nĩquel 165

A. As Jazidas Brasileiras 167

B. Jazidas no Resto do Mundo 172

CONCLUSOES

176

BIBLIOGRAFIA

APENDICE I - DADOS BRUTOS

APENDICE II - TECNICAS ANALITICAS 
TABELAS

Tabela 1 - Composição modal mëdia dos principais tipos 1itolögicos de Santa Fē (\% vol.).

Tabela 2 - Composição quĩmica mëdia dos principais tipos litolögicos de Santa $\mathrm{Fe}$ (\% peso).

Tabela 3 - Dados meteorolōgicos de Goiās e Aragarças: valo res mëdios mensais (1971-1975).

Tabela 4 - Dados meteorolögicos de Goiās e Aragarças: valo res mëdios anuais (1971-1975).

Tabela 5 - Avaliação semi-quantitativa dos minerais presen tes nos fäcies de alteração sobre dunito serpen tinizado.

Tabela 6 - Avaliação semi-quantitativa dos minerais presen tes nos fäcies de alteração sobre piroxenito.

Tabela 7 - Composição quĩmica mëdia (\% em peso de metal) dos fäcies de alteração sobre dunito. Dados das topossequencias XV e E6.

Tabela 8 - Composição quïmica mëdia (\% em peso do öxido) dos fäcies de alteração sobre dunito. Dados da topossequēncias XXVII e W4 e do perfil G.

Tabela 9 - Taxas de concentração dos värios oxidos em rela ção à rocha fresca.

Tabela 10 - Cālculo da composição química do dunito serpentinizado, a partir de seus constituintes.

Tabela 11 - Taxas de concentraçäo dos värios öxidos em relação à rocha fresca hipotētica. 
Tabela 12 - Composiçäo quĩmica (\% em peso) e förmula estrü tural dos minerais hipögenos.

Tabela 13 - Composição química (\% em peso) e razões molecu lares dos produtos da alteração.

Tabela 14 - Proporção dos cōxidos amorfos e mal cristaliza dos, em relação à sua quantidade total na amos tra.

Tabela 15 - Anālise quîmica das frações granulomëtricas (\% em peso).

Tabela 16 - Composição quỉmica dos fācies de alteração sobre peridotito (\% em peso).

Tabela 17 - Composição quĩmica de amostras provenientes do perfil py (\% em peso).

Tabela 18A- Composição quĩmica (\% em peso) das amostras do perfil $C$.

Tabela 18B- Teores em $\mathrm{Fe}_{2} \mathrm{O}_{3}$, MgO e NiO na fração laterïtica das amostras do perfil C (\% em peso).

Tabela 18C-Composição quĩmica (\% em peso) da crosta ferru ginosa.

Tabela 19 - Repartição dos elementos quimicos entre os minerais.

Tabela 20 - Balanço geoquĩmico para as amostras das topossequências XXVII e W4 (cālculo isovolume:\% da quantidade inicial do óxido).

Tabela 21A- Balanço geoquỉmico para o boxwork silicoso(cā culo isovolume:\% da quantidade inicial do öxido). 
Tabela 21B- Balanço geoquĩmico para a amostra 118 em relação à amostra 111 (cālculo isovolume: \% da quantidade do óxido em relação à amostra 111).

Tabela 22 - Balanço geoquĩmico para o perfil G (cālculo isovolume: \% da quantidade inicial do ōxido).

Tabela 23 - Balanço geoquímico para o perfil sobre piraxenito (cālculo isovolume: \% da quantidade. inicial do $\bar{x} \times i d o)$.

Tabela 24 - Balanço geoquímico para os perfis sobre peridoti to (cảlculo isovolume:\% da quantidade de öxido no fäcies menos alterado).

Tabela 25 - Balanço geoquỉmico da $\mathrm{SiO}_{2}$, $\mathrm{MgO}$ e $\mathrm{NiO}$, por setor da topossequência (cālculo isovolume:\% da quanti dade inicial do ōxido).

Tabela 26 - As jazidas de $\mathrm{Ni}$ do Brasil 


\section{FIGURAS}

Figura 1 .. Mapa geólōgico regional do sudoeste de Goiās

Figura 2 - Mapa geolōgico do distrito de Santa Fē (GO). Localização dos perfis estudados.

Figura 3 - Dados meteorolögicos: valores mēdios (1971 1975).

Figura 4 - A evolução do relevo.

Figura 5 - 0 perfil de alteração sobre dunito.

Figura 6 - Evolução da distribuição granulomētrica durante a alteração (amostras da topossequên cia W4).

Figura $7 A$ - Difratogramas de raios $X$ da serpentina:

Figura 7B - Diagramas de ATD da serpentina.

Figura 8 - Difratogramas de raios $x$ dos veios que cortam a rocha.

Figura 9 - Diagrama de ATD e difratogramas de raios $X$ da fração < 0,062 mm da amostra 9 (SG).

Figura 10 - Difratogramas de raios $X$ da vermiculita em grandes placas encontrada em veios.

Figura 11 - Diagramas de ATD e difratograma de raios $X$ da goethita.

Figura 12 - Difratogramas de raios $X$ de-amostras de garnierita. 
Figura 13 - Diagramas de ATD de amostras do perfil sobre piroxenito.

Figura 14 - Distribuição dos fācies de alteração.Linha E10.

Figura 15 - Distribuição dos fācies de alteração.Linha E6.

Figura 16 - Distribuição dos fãcies de alteração.Linha XV.

Figura 17 - Distribuição dos fäcies de alteração. Linha XXVII.

Figura 18 - Distribuição dos fācies de alteração.Linha W4.

Figura 19 - Filiações mineralögicas.

Figura 20 - Diagramas de ATD, mostrando o desaparecimento da serpentina e o aparecimento da goethita.

Figura 21 - Evoluçäo dos veios.

Figura 22 - Relação entre $i$ e densidade aparente.

Figura 23 - Variação dos teores mëdios com profundidades mëdias.Topossequências XV e E6.

Figura 24 - Coeficientes de correlação Pearson entre os teores de $\mathrm{Mg}, \mathrm{Fe}, \mathrm{Cr}, \mathrm{Co}, \mathrm{Cu}, \mathrm{Si}, \mathrm{Al}$ e $\mathrm{Ni}$ (284 amostras).

Figura 25A- Representação gräfica dos coeficientes de cor relação do $\mathrm{Mg}, \mathrm{Fe}, \mathrm{Cr}, \mathrm{Co}, \mathrm{Cu}, \mathrm{Si}, \mathrm{A} T$ e Ni, em função dos coeficientes de correlação do $\mathrm{Fe}$ e do Si.

Figura 25B- Representação gräfica dos coeficientes de cor relação do $\mathrm{Ni}$ com o Fe e Si nos diferentes fá cies de alteração. 
Figura 26 - Curvas de isoniquel. Linha E6.

Figura 27 - Curvas de isonĩquel. Linha XV.

Figura 28 - Curvas de isoniquel. Linha XXVII.

Figura 29 - Curvas de isonĩquel. Linha W4.

Figura 30 - Curvas de extração. Mētodo Segalen. Minerais de nĩque 1 .

Figura 31 - Curvas de extração. Mētodo Segalen. Vermiculi tas niqueliferas.

Figura 32 - Curvas de extração. Mētodo Segalen. SG e LA.

Figura 33 - Curvas de extração. Mētodo Segalen. Lateritas vermelhas.

Figura 34 - Variação dos teores absolutos de $\mathrm{SiO}_{2}, \mathrm{MgO}$ e $\mathrm{NiO}$, em função da densidade aparente.

Figura 35 - Variação dos teores absolutos de $\mathrm{Cr}_{2} \mathrm{O}_{3}$ e $\mathrm{Fe}_{2} \mathrm{O}_{3}$, em função da densidade aparente.

Figura 36 - Variação dos teores absolutos de $\mathrm{Al}_{2} \mathrm{O}_{3}$ e $\mathrm{CoO}$, em função da densidade aparente.

Figura 37 - Evolução dos elementos solūveis na alteração dos dunitos serpentinizados.

Figura 38 - Evolução dos elementos solūveis na alteração dos peridotitos e piroxenitos.

Figura 39 - Balanço do Nio por setor da topossequēncia (călcu 10 isovolume: g NiO/100 c C).

Figura 40 - Composição do minērio de $N i$ de Santa Fé. 
Figura A - Distribuição dos fãcies de alteração nos diferentes perfis da topossequência XXVII.

Figura B - Distribuição dos fäcies de alteração nos diferentes perfis da topossequência $W 4$.

Figura C - Distribuição dos fäcies de alteração nos diferentes perfis de poços esparsos.

Figura D - Histograma da distribuição granulomētrica das amostras da topossequência $\mathbf{W} 4$.

Figura E - Organograma dos trabalhos de laboratōrio. 
DOCUMENTAÇAO FOTOGRAFICA

Foto 1 - Visão geral do maciço ultrabāsico.

Foto 2 - Serra do Tira-Pressa, intensamente silicificada.

Foto 3 - Olivina ocupando o centro do reticulado de ser pentina. Veios de carbonato. Nicōis cruzados. Au mento aproximado: 110 vezes.

Foto 4 - Cristais de cromita circundados por vermiculitaclorita. Nicóis cruzados. Aumento aproximado: 90 vezes.

Foto 5 - Magnetita entre as bandas de serpentina. Nicóis paralelos. Aumento aproximado:90 vezes.

Foto 6 - Veio. de quartzo, mais bem cristalizado quando livre de ferro. Nicóis cruzados. Aumento aproximado: 110 vezes.

Foto 8 - Serpentina placóide (II), ocupando o centro do reticulo. Fe depositado no contato da serpentina I e da serpentina II. Nicōis cruzados. Aumento a proximado:220 vezes.

Foto 7 - Fantasma de olivina, preenchido por quartzo mi crocristalino. Nicōis cruzados. Aumento aproxima do: 90 vezes.

Foto 9 - Fantasma de olivina, preenchido por amorfos fer ruginosos. Nicōis cruzados. Aumento aproximado: 110 vezes. 
Os deuses não revelaram, no inĩcio, todas as coisas para nös;

com o correr do tempo, entretanto,

pela pesquisa, podemos saber mais acerca das coisas.

Contudo, a verdade certa, nenhum homem a conheceu, nem chegarä a conhecer, nem os deuses,

nem mesmo acerca das coisas que menciono.

Pois, ainda que, por acaso, viesse a dizer

a verdade final, ele pröprio não o saberia:

pois tudo não passa de uma teia urdida de pressupostos.

Xenöfanes, sēculo VI A.C. 


\section{INTRODUÇAO}

0 estudo da alteração supērgena das rochas ultrabäsicas apresenta um grande interesse, tanto do ponto de vista acadêmico, como no que diz respeito a suas aplica ções prāticas.

No dominio dos conhecimentos fundamentais, vi sa esclarecer os mecanismos que regem o comportamento geoquĩmico e cristaloquímico dos elementos, no decorrer do pro cesso de meteorização. Quase desprovidas de Al, em contraste com a grande maioria dos materiais crustais, as rochas ultrabāsicas colocam, quando de sua alteração, problemas es pecîficos. Não existe paralelismo absoluto com a evolução habitual das rochas aluminossilicatadas, processo controlado essencialmente pela solubilidade da sijlica e das bases, sendo o Al utilizado como elemento de referencia, por ser o menos mobilizável e por constituir-se o principal formador dos minerais de neogēnese. No caso das rochas ultrabāsicas, - Si e o Mg, seus principais constituintes, são, ambos, möveis, e serā a velocidade de eliminação de um em relação ao outro que determinarä os diferentes tipos de evolução.

No campo das aplicações, esse estudo apresen ta interesse econômico relativo à formação de minérios. As rochas ultrabāsicas possuem teores relativamente elevados em certos elementos menores, tais como $\mathrm{Ni}, \mathrm{Cr}$ e $\mathrm{Co}$. Os processos superficiais são capazes, sob certas condiçöes, de provocar concentração desses elementos, favorecendo, assim, o desenvolvimento de verdadeiras jazidas supergennicas. A in vestigação das variāveis envolvidas neste fenômeno poderă fornecer guias para a prospecção mineira.

o objetivo do presente trabalho é o de tra- 
çar a caracterização mineralögica e geoquïmica das rochas ultrabāsicas de Santa $F \bar{e}$ e de seus produtos de alteração, in vestigar os fatores determinantes de sua evolução sob condi ções superficiais e, finalmente, reconstituir os eventos que levaram à formação da jazida de $\mathrm{Ni}$.

Este estudo foi muito beneficiado pelos trabalhos anteriores concernentes ä alteração de rochas sob clima tropical, desenvolvidos principalmente nos ültimos vinte anos. Entre eles, estão os que, baseados em observações de campo e anälises mineralögicas e quỉmicas, estabele ceram as linhas gerais de evolução para os diferentes tipos de rochas (Bonifas 1959, Tardy 1969, Melfi $\xi$ Levi 1971, Levi $\xi$ Melfi 1972, Cerri 1974, Trescases 1975, Wackermann 1975, Pion 1979 etc). Outros tipos de abordagem, como sinteses experimentais (Hēnin $\xi$ Robichet 1953, Cailiēre et a.t. 1956; Hēnin $\xi$ Caillère 1963, Perruchot 1971 etc) e altera ção de rochas e minerais in vitro (Pedro 1964, Pedro $\xi$ Bitar 1966, Hypolito 1972, Delmas 1972 etc), permitiram precisar as condições físico-quïmicas que regulam as transformações e as neogêneses. 0 uso de modelos estatĩsticos (Wackermann 1975) e o cālculo dos equilibrios termodinämicos relativos à fase solūvel da alteração (Fritz $\xi$ Tardy 1973, Trescases 1975, Wackermann 1975 etc) aprofundaram 0 entendimento dos mecanismos da alteração supērgena.

A metodologia experimental, consagrada a par tir de 1964, quando da apresentação da tese de doutoramento de G.Pedro, intitulada "Contribuição ao estudo experimental da alteração geoquĩmica das rochas cristalinas", trouxe sub sĩdios valiosos à compreensão dos sistemas complexos estuda dos. Atravēs desta metodologia, é possĩvel, dentro de certos limites, controlar as variāveis, testar hipöteses e estabelecer, enfim, um quadro de referēncia para a anälise dos fenómenos da alteração. Os limites dessa abordagem estão, principalmente, na dificuldade de transposição dos resultados, obtidos através de modelos necessariamente simpli- 
ficados, às situações da natureza, em ambiente aberto, de mültiplas variāveis e interações complexas.

Por outro lado, os mētodos clāssicos das ciēncias naturais, fundamentados na observação, deparam- se com outro tipo de dificuldade: como compreender a gênese de um processo impossivel de ser observado em seu transcurso? o pesquisador tem acesso apenas a produtos jä evoluidos que sō conservam imperfeitamente: os vestīgios das etapas que marcaram sua histöria, e dos fatores que os engendraram. E necessärio todo um trabalho criativo de elaboração de hipoteses, de confronto delas com a realidade e de consequente reelaboração, num movimento de vai-e-vem, atē que a apreensão dos fenōmenos pareça atingida e que a teoria dê conta dos fatos observados.

A investigação do processo de alteração das rochas ultrabäsicas de Santa Fë foj realizada atravēs da me todologia acima descrita. Os resultados desse trabalho são expostos em 4 capitulos e resumidos numa 1 istagem das principais conclusões obtidas.

No primeiro capitulo, são analisados diversos aspectos do meio físico, considerados relevantes para o estudo da alteração supërgena: a natureza da rocha, o clima a que ela estā submetida atualmente, a conformação e a evolução do relevo e a repartição da vegetação.

- segundo capitulo trata das caracterizações mineralögica: e geoquĩmica dos produtos de alteração, mane $\underline{i}$ ras complementares de descrevê-los. Os dados mineralögicos dão uma idëia das transformações sofridas pelos materiais e informam, numa primeira aproximação, as variações na composição quĩmica; os dados quĩmicos, detalhando o comportamento dos elementos, sō assumem seu significado mais profundo no contexto mineralögico. Neste capītulo, descrições e interpretações andam juntas, terminando por compor um quadro 
explicativo das filiações mineralógicas e do destino dos e lementos químicos durante o processo de alteração.

O terceiro capitulo è consagrado a um ensajo interpretativo dos ferōmenos de alteração, ao nĩvel da paisagem, levando em conta a dimensão temporal. E, assim, contada a histöria evolutiva das rochas ultrabäsicas, desde a época de seu afloramento na superfĩcie atē os dias atuais. Trata-se de uma integração dos dados e interpretações contidas nos capittulos I e II; ë no contexto dessa sintese que se discute a gënese da jazida de Ni.

No quarto capitulo è avaliada a importância econōmica da jazida e são traçadas comparações com outras jazidas similares, brasileiras e estrangeiras.

Sob o tîtulo "Conclusões", destacam-se as principais lições tiradas deste estudo.

A lista de referēncias bibliogräficas diz respeito apenas aos artigos e livros citados explicitamente ao longo do texto.

A fim de tornar mais leve a leitura e, ao mesmo tempo, fornecer aos interessados maiores detalhes so bre as amostras estudadas e sobre as tēcnicas analjticas, são apresentados, à parte, os apēndices I e II.

Um documentārio fotogräfico, apresentando a $\underline{\underline{s}}$ pectos da paisagem e de lâminas delgadas complementa este trabatho. 


\section{- MEIO FISICO}

0 conhecimento dos diferentes aspectos. do meio fisico tem interesse no contexto deste trabalho, na me dida em que são suas características especificas que contro 1 am a dinâmica do processo da alteração supērgena. Assim, $\bar{e}$ - clima que determina a maior ou menor agressividade das so luções percolantes, sendo que as maiores temperaturas e a maior disponibilidade de äguas favorecem o mais räpido ataque das rochas. A vegetação tem um papel de destaque no modelado do relevo, controlando, em parte, a intensidade do avanço da frente de erosão em relação à frente de alteração. Sua influência direta sobre a evolução dos horizontes mais superficiais, por intermëdio dos ācidos hümicos, ē, muitas vezes, considerävel. As rochas são a matēria-prima do processo. Sua natureza mineralögica e química e sua textura de terminam, em grande parte, os rumos que a alteração pode to mar. As estruturas que apresentam, reflexo dos esforços tec tōnicos a que foram submetidas, facilitarão ou não a perco1 ação das äguas meteōricas. Enfim, as formas do relevo, pro dutos finais da interação morfogēnese-pedogēnese, tēm tam bēm um papel no processo de alteração meteōrica. Esta dä-se diferentemente em cada compartimento topogräfico, seguindo uma certa tendência em flancos suaves com drenagem intensa, distinta da seguida em baixadas mal drenadas.

Isto posto, passar-se- $\bar{a}$ à caracterização detalhada do meio físico da região em estudo. 


\section{Situação Geogrāfica}

A região de Santa Fé situa-se no sudoeste do Estado de Goiäs, na região geogräfica conhecida como Centro oeste brasileiro.

0 complexo ultramä́fico, balizado pelas coordenadas $51015^{\prime} \mathrm{W}$ e $15040^{\prime} \mathrm{S}$, dista $3 \mathrm{~km}$ a NW da cidade de Santa Fë, municipio de Juçara. Tem forma elipsoidal, com o eixo maior na direção NS e o menor na direção EW, medindo respectivamente 9,5 e $6,5 \mathrm{~km}$. E formado de morrotes esparsos ou agrupados, de altitude variāvel em torno de $550 \mathrm{~m}$, po dendo alcançar ate $650 \mathrm{~m}$, distribuĩdos por uma superfície aplainada a altitudes de 420 a $450 \mathrm{~m}$, com suave declive para $N$, em direção ao rio Araguaia.

0 acesso à ārea ē feito a partir de Goiānia, pela rodovia estadual asfaltada GO-4 atē Goiäs Velho, num percurso de cerca de $150 \mathrm{~km}$. Desta cidade a Santa Fé, são mais $130 \mathrm{~km}$ em estrada não pavimentada,passando por Juçara, sede do municīpio. Internamente o maciço ē recortado por pequenas estradas abertas pela Montita Mineradora Ltda., con cessionäria da ārea, e tangenciado a leste pela rodovia estadual G0-28 que liga Santa Fé a Britänia.

\section{Quadro Geológico}

\section{A. Geologia Regional}

Na região centro-oeste brasileira, podem ser distinguidas quatro unidades tectōnicas de idade prē- cambriana, quais sejam: Prē-Cambriano indiferenciado ou Comple xo Basal, Sistema de Dobramentos Araxā, Sistema de Dobramen tos Paraguai-Araguaia e Sistema de Dobramentos Brasilia (A] meida 1967). Os limites setentrionais da Bacia do Paranā a- 
tingem os estados de Mato-Grosso e Goiās, sendo a ī represen tados pelas Formações Furnas (D), Ponta-Grossa (D) e Aquidauana (C). Ao sul de Goiās, ocorrem rochas alcalinas e ultrabāsicas de idade cretäcea, pertencentes ã Formação Iporā (Guimarães et $a z$. 1968). Formações detrîtico-lateriticas terciārias e quaternärias recobrem extensas regiões aplaina das e planicies aluviais.

As unidades acima mencionadas e suas relações são mostradas na figura 1 , esboço simplificado das folhas Goiās e Goiānia da carta do Brasil ao milionēsimo (Schobbenhaus Fo et al. 1975). Da memöria explicativa que acompanha o mapa, foram resumidas as considerações que se seguem.

As rochas agrupadas sob o nome de Prë- Cambriano indiferenciado constituem um antigo craton metamorfi zado, representado por gnaisses, migmatitos, quartzitos, mi ca-xistos, eruptivas diversas, metabasitos e meta-conglomerados. São orientadas predominantemente na direção NE, resultado do ültimo processo que afetou a região. Intrusivos nestas rochas são os trēs grandes complexos ultrabāsicos de Niquelândia, Canabrava e Barro Alto, alēm de värios pequenos corpos. (Angeiras 1968 e Thayer 1972). 0 padrão geocronolögico é complexo, mostrando idades desde $4000 \mathrm{~m} . \mathrm{a}$. para as ultrabāsicas, atē rochas afetadas pelo ciclo Transamazōnico (2000 m.a.).

Sobre o complexo basal arrasado, depositaram se os sedimentos do Grupo Araxă, durante o ciclo Uruaçuano (900 a $1300 \mathrm{~m} . \mathrm{a}$.$) , conforme Almeida 1971. São rochas sedi-$ mentares do fãcies ep'idoto-anfibolito, de direção geral NS e $N E-S W$.

Durante o ciclo Brasiliano, apōs longo perīo do erosivo que dissecou a cadeia orogēnica do ciclo uruaçua no, processou-se a sedimentação do grupo Bambuĩ (570 a $62 \overline{0}$ 


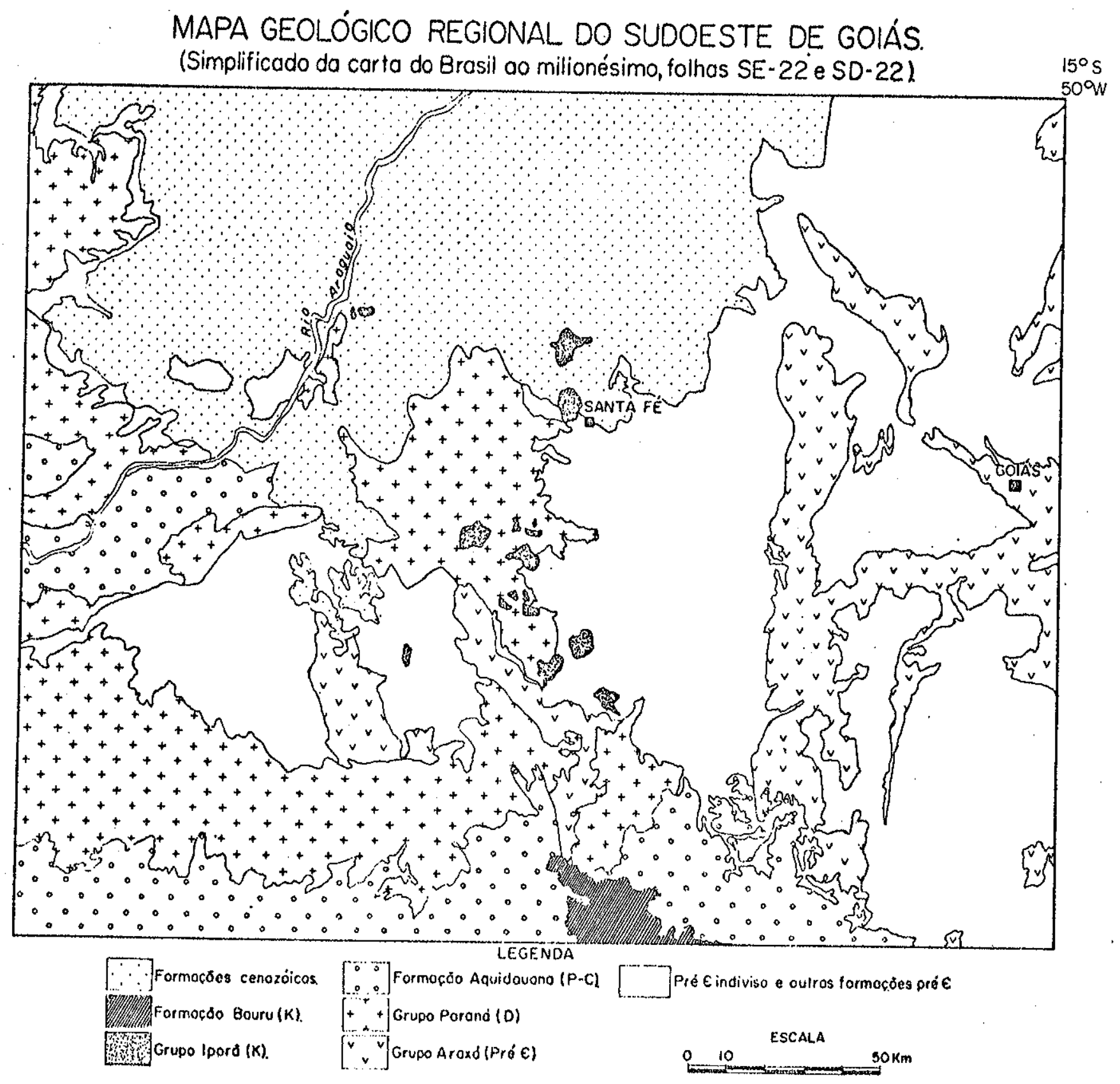

Fig. I 
m.a.), com pelitos e psamitos associados a calcārios e dolo. mitos, posteriormente metamorfizados ao nĩvel do fäcies xis to-verde (Marini et az. 1974). Tambēm durante este ciclo, num estägio mais precoce $(620$ a $900 \mathrm{m.a.})$, depositaram- se os sedimentos miogeossinclinais dos Grupos Cuiabā e Tocantins, constituindo a faixa de dobramentos Paraguai-Araguaia (A1meida 1971).

No Paleozöico, apös um longo período de ero são que aplainou a superficie das unidades anteriores, iniciou-se a deposição dos sedimentos da Bacia do Paranā. Na região considerada, afloram os sedimentos arenosos da Forma ção Furnas, os siltitos e folhelhos da Formação Ponta-Grossa e os sedimentos continentais neocarbonifferos da Formação Aquidauana.

No Cretäceo superior, relacionados provavel mente à reativação Wealdeniana, ocorreram intrusões de carā ter ultrabāsico-alcalino, que constituem o Grupo Iporā (Gui marães et $a z$. 1968, Lindenmayer $\xi$ Lindenmayer 1971). Entre estas destacam-se os maciços de Santa Fē (Barbour 1976), ser ra Agua Branca (Justo 1973), Morro do Engenho (Chaban $\xi$ San tós 1973) e Iporä (Pena $\xi$ Figueiredo 1973 e Danni 1974).

Sobre uma superfície aplainada do Prë- Cambriano indiferenciado dos Grupos Araxä e Tocantins, e sobre os sedimentos paleozöicos, depositaram-se as coberturas cenozöicas, não sō ao longo dos cursos d'ägua, mas tambëm nos interflüvios. Os depōsitos cenozöicos mais recentes são constituidos por aluviões marginais dos grandes rios.

\section{B. Geologia Local}

0 maciço ultramäfico de Santa $F \bar{e}$ compõe- se de um domo predominantemente dunitico, intrusivo em gnaisses regionais, parcialmente recobertos por sedimentos ter- 
ciärios, atravessando uma sequência de arenitos devonianos. Datações K-Ar em rochas do maciço acusam uma idade em torno de $80 \mathrm{m.a}$. (Barbour et az. 1979). De acordo com esses auto res, os gnaisses regionais apresentam idade $\mathrm{Rb}-\mathrm{Sr}$ de 467 m.a., sendo, portanto, relacionados ao ciclo Brasiliano.

O corpo intrusivo è de natureza ultramāficoalcalina e tem forma ovalada com o eixo maior na direção NS, medindo aproximadamente $9,5 \mathrm{~km}$, e o menor na direção EW, com cerca de $6,5 \mathrm{~km}$. Trata-se de um domo zonado de nūcleo duñ̄tico, envolvido por camadas descontinuas e concêntricas de peridotitos e piroxenitos. Os dunitos são as rochas mais abundantes, constituindo mais de $2 / 3$ da ārea aflorante. 0 pe ridotito ocorre em faixas descontinuas a N, E, W e SE, sempre em contato com os dunitos. Os piroxenitos formam uma faixa mais continua e longa a NW, e faixas estreitas e descontinuas na borda $E$, em contato com o peridotito ou direta mente com o dunito (figura 2). Nos furos de sondagem aparecem niveis interestratificados de peridotito e piroxenito.

Rochas alcalinas encontram-se registradas co mo pequenos corpos, ocorrendo ora no limite $N$ do dunito,prō ximas ao contato com peridotitos e piroxenitos (missourito), ora a SE do corpo intrusivo, no contato com 0 embasamento. Foram ainda registradas ocorrências de missourito e essexito a menos de $2 \mathrm{~km}$ do complexo (Souza 1978), bem como de lampröfiros e fonōlitos (Barbour 1976).

Nos contatos hä sinais evidentes de metamorfismo, representados por halos que vão desde albita-epidoto hornfels até feldspato-cordierita-hornfels (Lessa sọ et az. 1971). Localmente, nos gnaisses encaixantes, podem ocorrer variedades alcalinas de anfibōlio, indicando metassomatismo ligado à intrusão (Barbour et az. 1979).

Do ponto de vista de sua estrutura, o maciço constitui um domo zonado e, segundo Barbour 1976, três sis.- 


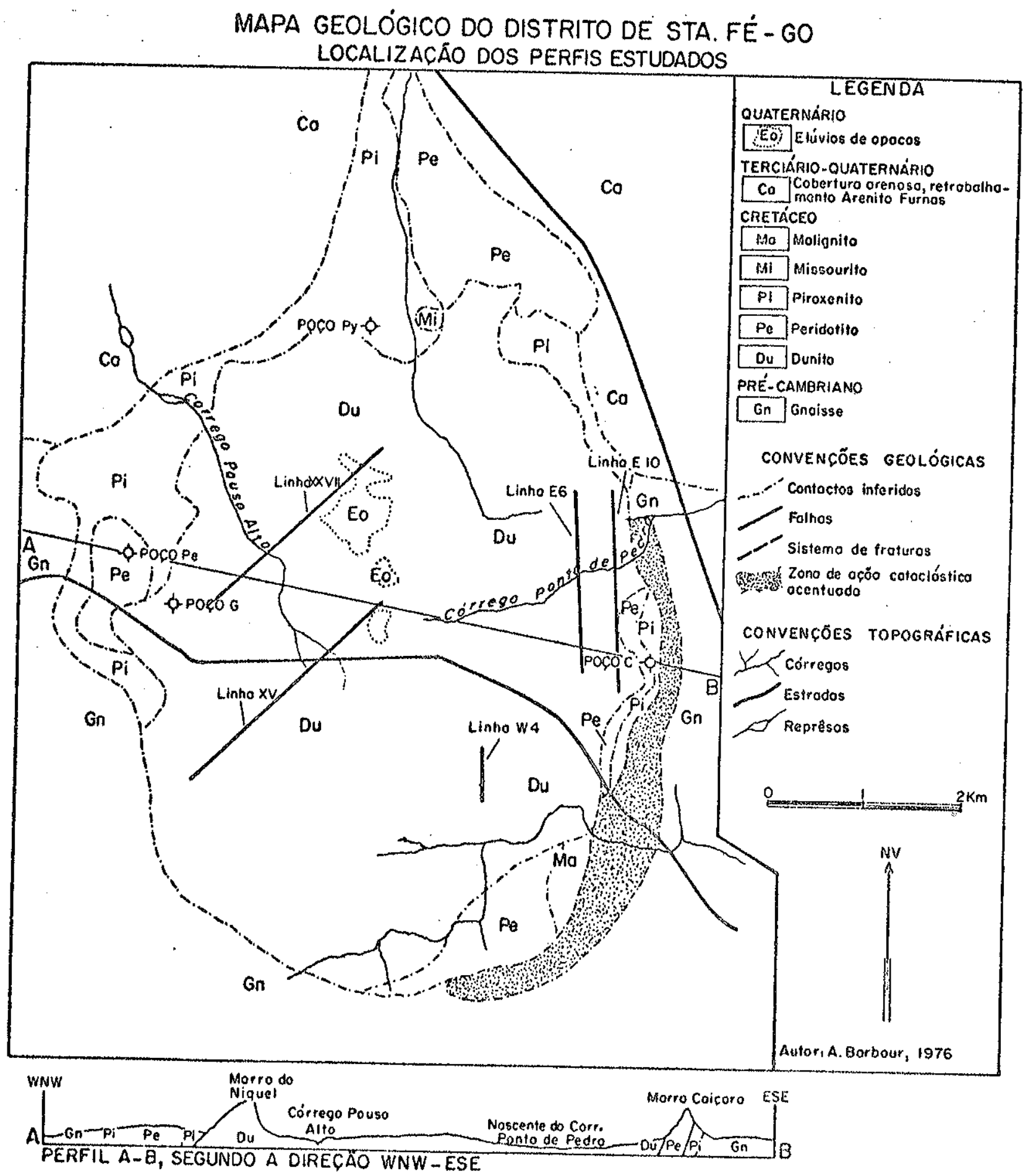

Fig. 2 
temas de fraturamento podem ser evidenciados:

- sistema de fraturas paralelas ao contato, de pequena extensão, responsāvel pelo escalonamento dos mor ros perifēricos. Deve ter sido originado pelos esforços da época da intrusão;

- sistema de grandes fraturas e falhas na di reção NE, originadas durante ou apōs a intrusão;

- sistema de microfraturamento de atitude ho rizontal a sub-horizontal, relacionado ao processo de serpentinização.

0 conjunto de caracteristicas acima descritas coloca o corpo ultramäfico de Santa Fë como pertencente à associação dunito-piroxenito-sienito alcalino, na tipologia esboçada por Berbert 1970.

Todo o maciço è afetado por transformações mineralögicas tardias que levaram à serpentinização generalizada e à existência de faixas de alteração hidrotermal compostas principalmente por vermiculita e opacos, conforme o que foi descrito por Barbour 1976.

C. Caracterização Petrogräfica e Quỉmica das Rochas do Complexo

Os tipos petrogräficos presentes no maciço estão representados, segundo Souza 1978, por uma associação ultramäfica normal, largamente dominante, e por uma associa ção mäfica e ultramäfico-alcalina de expressão localizada. Esta ültima compõe-se de missouritos, essexitos, malignitos e fonölitos.

A associação dominante é constituída de duni 
tos, peridotitos (wehrlitos), e clinopiroxenitos. 0s dunitos, de granulação fina a mëdia, são formados essencialmente por olivina, irregularmente serpentinizada. Secundariamente ocorrem clinopiroxênio, opacos, carbonatos e palhetas micāceas de natureza vermiculĩtica. 0 padrão textural ē definido por um reticulado poliēdrico de serpentina fibrosa constituida por duas bandas justapostas, onde lamelas do mi neral se dispöem normalmente às paredes e cujos centros são ocupados ou por cristais remanescentes de olivina magnesiana, ou por serpentina tabular. Opacos idiomörficos octaēdri cos constituijos por cromita distribuem-se irregularmente por toda a rocha. Muitas vezes em torno destes, ou raramente espalhado, ocorre um mineral micäceo do tipo vermiculita ou clorita. Opacos xenomorfos de granulação mais fina (magnetita) dispõem-se entre as bandas de serpentina. Finas e descontinuas vênulas de carbonato e brucita não são raras e ocorrem disseminadas pelo serpentinito. 0 talco, muito escasso, apresenta-se como finas e incipientes lamelas associadas à serpentina, olivina ou piroxênio.

Os peridotitos são texturalmente hipidiomörficos, de granulação mēdia a grosseira, compostos de olivina magnesiana e diopsidio principalmente, e por opacos, flo gopita e carbonatos como acessorios. Nestas rochas, a quantidade de opacos idiomörficos $\vec{e}$ maior que nos dunitos e o grau de serpentinização è menor, dado que este fenōmeno incide principalmente sobre as olivinas, cuja quantidade è me nor.

Os clinopiroxenitos são rochas hipidiomörficas a xenomörficas, de granulaçäo mēdia a grosseira, onde os grăos de diopsidio atingem mais de $85 \%$ do total. 0 restante $\bar{e}$ composto por opacos, flogopita e titanita.

Os três tipos 1itolögicos apresentam-se frequentemente recortados por veios brancos que atingem espessuras de atē alguns milimetros, compostos principalmente. 
- por carbonatos de Mg e Ca, associados ou não a brucita, e por serpentina bem cristalizada.

Do ponto de vista quïmico, as rochas ultramä ficas de Santa $F \bar{e}$ são rochas magnesianas a calcio-magnesianas da sequência sifêmica (Pedro $\xi$ Delmas 1973), cuja carac terĩstica principal $\bar{e}$ a grande pobreza em älcalis e em alumina. Os dunitos e peridotitos são rochas ultrabäsicas, sen do que o piroxenito classifica-se como bäsica. 0s trēs tipos, entretanto, são ultramāficos, dada a predomināncia absoluta de minerais mäficos.

As tabelas 1 e 2 mostram dados de composição modal e quimica dos principais tipos litológicos de Santa Fe.

D. O Fenômeno da Serpentinização

As rochas peridotīticas, ao serem levadas a niveis mais superficiais da crosta, sofrem geralmente trans formações mineralögicas de retromorfose: serpentinização. Es se fenōmeno ē generalizado no complexo de Santa $F \bar{e}$, onde ob serva-se a olivina sempre invadida pela serpentina, numa proporção que pode ultrapassar $90 \%$, situando-se em mēdia em torno de $60 \%($ tab. 1$)$.

A serpentinizaçäo è uma reação de hidratação, acompanhada de uma oxidação parcial do Fe. Produz-se geralmente em profundidade, provavelmente durante a mise-en-place, sob ação de āguas ascendentes de origem magmätica ou de origem meteōrica, esta mobilizada dos sedimentos.

Pode ser explicada atravës de uma reação entre olivina e ăgua, a volume constante (Turner $\xi$ Verhoogen 1960): 
TABELA 1

COMPOSIÇAO MODAL MEDIA DOS PRINCIPAIS TIPOS LITOLOGICOS DE SANTA FE (\% VOL.)

$\begin{array}{lccr} & \text { dunito }(1) & \text { peridotito }(2) & \text { piroxenito } \\ \text { clinopiroxēnio } & 0,6 & 43,4 & 89,0 \\ \text { olivina } & 29,6 & 35,9 & 1,6 \\ \text { Olivina serpentinizada } & 62,5 & 14,1 & - \\ \text { minerais micäceos } & 0,5 & 1,7 & 1,0 \\ \text { carbonatos } & 2,3 & 0,7 & 0,8 \\ \text { opacos } & 2,3 & 4,2 & 2,4\end{array}$

(1) - mëdia de 7 anālises (Souza 1978)

(2) - média de 6 anātises (Souza 1978)

(3) - mēdia de 4 anālises (Souza 1978) 


\section{TABELA 2}

COMPOSIÇAO QUTMICA MEDIA DOS PRINCIPAIS TIPOS LITOLOGICOS DE SANTA FE (\% EM PESO)

\begin{tabular}{|c|c|c|c|c|c|}
\hline & dunito & peridot & tito & piroxen & ito \\
\hline $\mathrm{SiO}_{2}$ & 36,34 (1) & 44,47 & $(3)$ & 50,57 & (4) \\
\hline $\mathrm{TiO}_{2}$ & $0,10(1)$ & 1,50 & (3) & 1,74 & (4) \\
\hline $\mathrm{Al}_{2} \mathrm{O}_{3}$ & 0,16 (1) & 1,20 & (3) & 1,93 & (4) \\
\hline $\mathrm{FeO*}$ & $13,15(1)$ & 13,53 & (3) & 6,93 & (4) \\
\hline $\mathrm{MnO}_{2}$ & 0,22 (1) & 0,19 & (3) & 0,11 & (4) \\
\hline $\mathrm{MgO}$ & $41,10(1)$ & 24,27 & (3) & 16.17 & (4) \\
\hline $\mathrm{CaO}$ & $1,50(1)$ & 13,05 & $(3)$ & 20,54 & (4) \\
\hline $\mathrm{Na}_{2} \mathrm{O}$ & 0,02 (1) & 0,14 & (3) & 0,33 & (4) \\
\hline $\mathrm{K}_{2} \mathrm{O}$ & 0,05 (1) & 0,15 & (3) & 0,12 & (4) \\
\hline $\mathrm{P}_{2} \mathrm{O}_{5}$ & $0,01 \quad(1)$ & 0,03 & (3) & 0,03 & (4) \\
\hline $\mathrm{H}_{2} \mathrm{O}^{+}$ & 7,35 (1) & 1,69 & (3) & 1,55 & (4) \\
\hline NiO & $0,23 \quad(2)$ & - & & 0,06 & (5) \\
\hline $\mathrm{COO}$ & $0,020(2)$ & - & & 0,011 & (5) \\
\hline $\mathrm{Cr}_{2} \mathrm{O}_{3}$ & 0,35 (2) & - & & 0,11 & (5) \\
\hline CuO & $0,003(2)$ & - & & 0,005 & (5) \\
\hline (1) mëdia de & 2 anālises & (Souza 1978) & & & \\
\hline (2) mëdia de & 3 anälises & (Lab.de Geoq & quĩmica, IGUSP) & & \\
\hline (3) mēdia de & 4 anälises & (Souza 1978) & & & \\
\hline (4) mëdia de & 2 anālises & (Souza 1978) & & & \\
\hline (5) mëdia de & $\begin{array}{l}2 \text { anäìses } \\
\text { computado cont }\end{array}$ & $\begin{array}{l}\text { (Lab.de Geoq } \\
{ }_{0} \text { Feo }\end{array}$ & quĩnica, IGUSP) & & \\
\hline
\end{tabular}



$5 \mathrm{Mg}_{2} \mathrm{SiO}_{4}+4 \mathrm{H}_{2} \mathrm{O} \longrightarrow 2 \mathrm{Mg}_{3} \mathrm{Si}_{2} \mathrm{O}_{5}(\mathrm{OH})_{4}+4 \mathrm{MgO}+\mathrm{SiO}_{2}$ $700 \mathrm{~g} \quad 72 \mathrm{~g} \quad 160 \mathrm{~g} \quad 60 \mathrm{~g}$ $219 \mathrm{cc}$
$220 \mathrm{cc}$

Neste caso hā evacuação de Si e Mg em solução, o que poderā levar à deposição de filões de quartzo e calcedónia e de mi nerais magnesianos. 0 Fe contido na olivina transforma-se em magnetita.

E possivel imaginar serpentinização sem modi ficação quĩmica do conjunto, mas com aumento considerāvel de volume e formação de brucita:

$2 \mathrm{Mg}_{2} \mathrm{SiO}_{4}+3 \mathrm{H}_{2} \mathrm{O} \longrightarrow \mathrm{Mg}_{3} \mathrm{Si}_{2} \mathrm{O}_{5}(\mathrm{OH})_{4}+\mathrm{Mg}(\mathrm{OH})_{2}$
$280 \mathrm{~g}$
$54 \mathrm{~g}$
$276 \mathrm{~g}$
$58 \mathrm{~g}$
$87,6 \mathrm{cc}$
$110 \mathrm{cc}$
$24,6 \mathrm{cc}$

0 destino do $\mathrm{Fe} \bar{e}$ o mesmo que no caso anterior, mas, propor cionalmente à quantidade de olivina de partida, forma-se me nos magnetita. Porisso, em situações intermediārias, com menor aumento de volume, a magnetita e a brucita aparecerão em correlação negativa (De Waal 1971, apud Trescases 1975).

Em Santa Fē, a ausência quase total de bruci ta na rocha fresca exclui a possibilidade de uma generaliza da transformação estritamente isoquỉmica. Mais plausivel $\overline{\bar{e}}$ a hipōtese de que houve pelo menos uma certa remoção de sijlica e magnésia em solução, corroborada pela existēncia de filões de vermiculita que teriam sido formados a partir de tas soluções.

Associada ao fenōmeno de serpentinização, po de ocorrer formação de talco, a partir da serpentina, basica mente por 2 mecanismos(C1ark 1978): 
a) adição de sîtica

$$
\mathrm{Mg}_{3} \mathrm{Si}_{2} \mathrm{O}_{5}(\mathrm{OH})_{4}+2 \mathrm{SiO}_{2} \longrightarrow \mathrm{Mg}_{3} \mathrm{Si}_{4} \mathrm{O}_{10}(\mathrm{OH})_{2}+\mathrm{H}_{2} \mathrm{O}
$$

b) remoção de magnésia

$$
2 \mathrm{Mg}_{3} \mathrm{Si}_{2} \mathrm{O}_{5}(\mathrm{OH})_{4}+\mathrm{H}_{2} \mathrm{O} \longrightarrow \mathrm{Mg}_{3} \mathrm{Si}_{4} \mathrm{O}_{10}(\mathrm{OH})_{2}+3 \mathrm{MgO}+3 \mathrm{H}_{2} \mathrm{O}+\mathrm{xH}_{2} \mathrm{O}
$$

Outras transformações da serpentina podem le var ao aparecimento de talco, carbonato e sîlica (Clark 1978):

a') $2 \mathrm{Mg}_{3} \mathrm{Si}_{2} \mathrm{O}_{5}(\mathrm{OH})_{4}+3 \mathrm{CO}_{2} \longrightarrow \mathrm{Mg}_{3} \mathrm{Si}_{4}{ }_{10}(\mathrm{OH})_{2}+3 \mathrm{MgCO}_{3}+3 \mathrm{H}_{2} \mathrm{O}$

b') $\mathrm{Mg}_{3} \mathrm{Si}_{2} \mathrm{O}_{5}(\mathrm{OH})_{4}+3 \mathrm{CO}_{2} \longrightarrow 3 \mathrm{MgCO}_{3}+2 \mathrm{SiO}_{2}+2 \mathrm{H}_{2} \mathrm{O}$

c') $\mathrm{Mg}_{3} \mathrm{Si}_{4} \mathrm{O}_{10}(\mathrm{OH})_{2}+3 \mathrm{CO}_{2}+3 \mathrm{H}_{2} \mathrm{O} \longrightarrow 3 \mathrm{MgCO}_{3}+4 \mathrm{SiO}_{2}+4 \mathrm{H}_{2} \mathrm{O}$

No maciço estudado, parece não ocorrer silicificaçăo hipögena, pois não foram encontrados vestigios desse processo na rocha fresca. Porisso as $2 \bar{u} 1$ timas equações não parecem descrever adequadamente o que se passa. 0 talco e os carbonatos encontrados nas rochas de Santa Fë de vem ter sido originados segundo o descrito por equações do tipo a, b ou a'.

As crostas silicosas existentes em Santa $F \bar{e}$, bem como as silicificações locais, estão asșociadas a fenômenos supërgenos e constituirão objeto de estudo em capitu10 à parte.

Em Santa Fè, ainda associada à serpentinização, cabe mencionar, a nĩvel microscōpico, a formação de pa Thetas micāceas envolvendo os grãos de cromita. Parecemter sido formadas por reação de borda entre a serpentina e a cromita. Suas caracteristicas ópticas e seu comportamento 
aos raios $x$ indicam que deve tratar-se de vermiculita-clorita.

\section{Clima}

$\mathrm{Na}$ regiäo centro-oeste brasileira, a rede de estações meteorolögicas ē muito pouco densa. Entretanto, prō ximo a Santa $\overrightarrow{F e}$ existem duas estações, uma situada a $110 \mathrm{~km}$ a leste (Goiās), e outra, a $120 \mathrm{~km}$ a oeste (Aragarças), ambas mantidas pelo Departamento de Meteorologia do Ministērio da Agricultura. 0 s dados que puderam ser obtidos dizem respeito a temperatura, pluviosidade e evaporação e concernem apenas ao perĩodo de 1971 a 1975, Em setembro de 1973, a CPRM insta lou um pluviōmetro na cidade de Santa $F \bar{e}$ e executou medidas mensais ate dezembro de 1975. Como Santa Fe encontra-se numa posição geogrä́fica intermediāria entre as duas estações acima mencionadas, aproximadamente a mesma latitude e a uma altitude tambëm intermediäria, a anălise dos dados meteorolo gicos relativos a Goiās e Aragarças servirä para bem caracte rizar o clima a $\mathbb{i}$ reinante.

De modo geral, pode-se afirmar que a região de Santa $F \bar{e}$ situa-se numa provĩncia climätica classificada como tipo Aw de Koeppen, correspondendo a savana tropical de inverno seco (abril a setembro), e verão chuvoso (outubro a março). Majs de $80 \%$ da precipitação anual cai no verão, sendo comum nesta ēpoca as trovoadas e os fortes aguaceiros. Na estação seca, a estiagem e bastante rigorosa, havendo pouca ou nenhuma chuva nos meses de junho e julho. Quanto ao regime tērmico, a ärea apresenta clima quente, com temperaturas mēdias mensais sempre superiores a $200 \mathrm{C}$.

Estas são caracterīsticas gerais, välidas para uma grande parte do Centro-0este brasileiro (Galvão 1960). A anălise dos dados referentes a Goiäs e Aragarças, resumidos nas tabelas 3 e 4 e figura 3 , apesar de relativos a um 
TABELA 3

DADOS METEOROLOGICOS DE GOIAS E ARAGARÇAS: VALORES MEOIOS MENSAIS (1971 - 1975)

\begin{tabular}{|c|c|c|c|c|c|c|}
\hline $\begin{array}{c}\text { Precipit taçäo } \\
\qquad(m m)\end{array}$ & $\begin{array}{l}\text { Temp. mäxima } \\
\text { mëdia }(D C)\end{array}$ & $\begin{array}{l}\text { Temp.mintma } \\
\text { mëdia }(8 C)\end{array}$ & $\begin{array}{c}\text { Temp.mäxima } \\
\text { absoluta. }(9 \mathrm{C})\end{array}$ & $\begin{array}{l}\text { Temp.minnima } \\
\text { absoiuta }(Q C)\end{array}$ & $\begin{array}{l}\text { Amplitude } \\
\text { tërmica (QC) }\end{array}$ & $\begin{array}{l}\text { Temp.mēdi } \\
\quad(\mathrm{OC})\end{array}$ \\
\hline 246,8 & 30,9 & 21,4 & 34,4 & 19,3 & 15,1 & 25,3 \\
\hline 153,8 & 30,9 & 21,5 & 34,4 & 19,9 & 14,4 & 25,2 \\
\hline 235.7 & 31,0 & 21,4 & 34.1 & 19.9 & 14.2 & 25,2 \\
\hline 90.8 & 30,4 & 20,3 & 33,3 & 16,5 & 16,8 & 24,6 \\
\hline 17.8 & 30,8 & 17.9 & 32,8 & 12,3 & 19.8 & 23,3 \\
\hline 0,0 & 31,3 & 15,9 & 33,5 & 11,5 & 22,0 & 22,7 \\
\hline 4.3 & 31,1 & 14,3 & 33,8 & 9,2 & 24.6 & 21,3 \\
\hline 24.0 & 33,8 & 16,3 & 36,1 & 12,3 & 23,8 & 24,3 \\
\hline 24,8 & 33,9 & 19,8 & 37,1 & 14,2 & 23,0 & 26,2 \\
\hline 181,1 & 32,1 & 21,3 & 36.6 & 18,4 & 18,2 & 25,7 \\
\hline 214.4 & 30,9 & 21,6 & 34,0 & 19,9 & 13,9 & 25,2 \\
\hline 284.6 & 30,4 & 21,4 & 34,0 & 19,8 & 14,2 & 24,9 \\
\hline
\end{tabular}

ARAGARÇAS

\begin{tabular}{|c|c|c|c|c|c|c|}
\hline $\begin{array}{c}\text { Precipitação } \\
\text { (mm) }\end{array}$ & $\begin{array}{l}\text { Temp.mäxima } \\
\text { mëdia (QC) }\end{array}$ & $\begin{array}{l}\text { Temp.minima } \\
\text { médta (QC) }\end{array}$ & $\begin{array}{l}\text { Temp.mäxima } \\
\text { absoluta (PC) }\end{array}$ & $\begin{array}{l}\text { remp.mintma } \\
\text { absoluta }(Q C)\end{array}$ & $\begin{array}{c}\text { Amplitude } \\
\text { tërmica (QC) }\end{array}$ & $\begin{array}{c}\text { Temp.média } \\
\text { (PC) }\end{array}$ \\
\hline
\end{tabular}

\begin{tabular}{|c|c|c|c|c|c|c|c|}
\hline $\mathrm{J}$ & 175,2 & 31,7 & 20,7 & 35,4 & 18,8 & 16,4 & 25,4 \\
\hline$F$ & 223,5 & 31,5 & 20,6 & 35,2 & 18,7 & 16,5 & 24,8 \\
\hline$M$ & 219,0 & $37, ?$ & 20,9 & 34.8 & 19.5 & 15.4 & 24.8 \\
\hline A & 125,2 & 31,7 & 20,2 & 34,3 & 17,3 & 17,0 & 24,6 \\
\hline$M$ & 36,8 & 31,9 & 18,7 & 33.8 & 14,5 & 17.7 & 23,8 \\
\hline J & 1,2 & 32,2 & 18,1 & 33,8 & 14,5 & 19,4 & 23,3 \\
\hline $\mathbf{J}$ & 1.7 & 31,9 & 17,6 & 34,5 & 10,9 & 22,4 & 22,9 \\
\hline A & 8.2 & 34,6 & 17,1 & 36,7 & 15.1 & 20,4 & 25,1 \\
\hline S & 24,0 & 35,2 & 19,1 & 38,0 & 17,6 & 18,4 & 27,1 \\
\hline 0 & 145,2 & 32,4 & 27.8 & 37,0 & 18,8 & 18,2 & 25.5 \\
\hline$N$ & 228,6 & 31.0 & 20,8 & 34,4 & 18,9 & 15,6 & 24,9 \\
\hline D & 282,8 & 30,8 & 20,7 & 34,6 & 19,1 & 15.5 & 24.7 \\
\hline
\end{tabular}

GOIXS 
TABELA 4

DADOS METEOROLOGICOS DE GOIAS E ARAGARÇAS:

VALORES MEDIOS ANUAIS (1971 - 1975)

Inverno: abril a setembro

verão: outubro a março

Aragarças

Precipitação anual mëdia (mm)

Evaporação anual mëdia (mm)

Temperatura mëdia anual (OC)

Temperatura mäxima abs. (OC)

Temperatura mínima abs. (OC)

Precipitação mêdia (mm)

Evaporação média (mm)

Temperatura média

(QC)

Amplitude tërmica mëdia $(O C)$
1478,1

1471,4

1334

1250

24,5

24,7

38,3

39,4

4,0

5,4

$I-161,7$

$v-1316,4$

197,1

1274,3

$I-843,8$

$v-490,6$

825,5

424,4

I - 23,7

$V-25,3$

24,5

25,0

$I-21,7$

$v-15,0$

16,3 

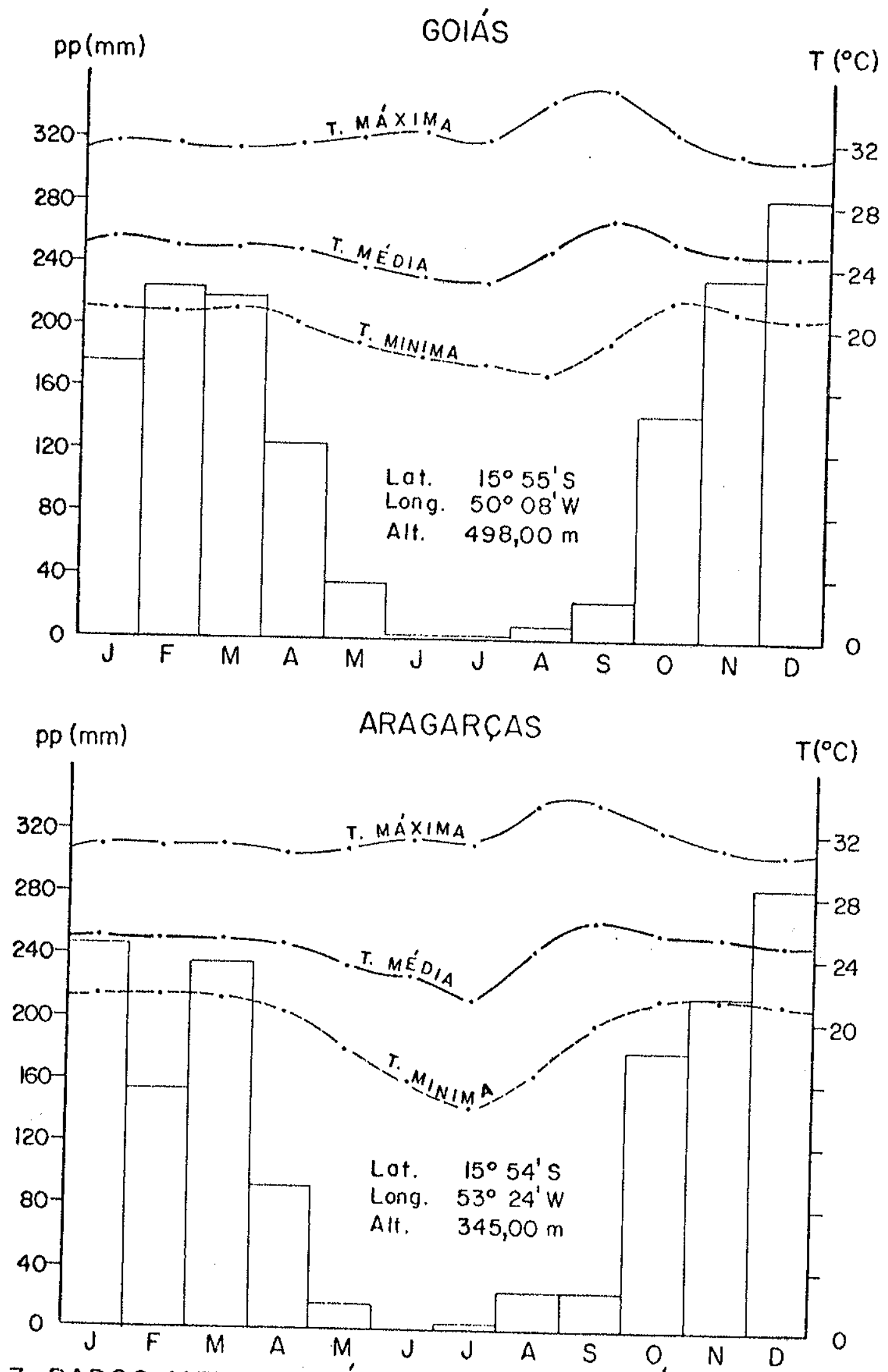

Fig.3-DADOS METEOROLÓGICOS: VALORES MÉDIOS (1971-1975) 
curto período de anos, permitirā melhor precisar as flutua ções dos parámetros meteorolögicos da região estudada.

A. Pluviosidade

A precipitação anual mëdia ē de cerca de $1500 \mathrm{~mm}$, dos quais mais de $85 \%$ concentram-se no verão. A pre cipitação mëdia nesta estação chega a mais de $1300 \mathrm{~mm} e$, no inverno, não passa de $200 \mathrm{~mm}$. 0 mês mais chuvoso, estatisticamente, $\vec{e}$ dezembro, com uma mëdia de $285 \mathrm{~mm}$, apresentando um māximo de $426 \mathrm{~mm}$ e um mīnimo de $153 \mathrm{~mm}$, para o perĩodo considerado. 0 mẽs mais seco é junho, quando, geralmente, a precipitação é nula, tendo, no entanto, alcançado $6,7 \mathrm{~mm}$ no ano de 1975.

Na maior parte das vêzes, a precipitação diä ria não ultrapassa $20 \mathrm{~mm}$, sendo raras as chuvas que atingem mais de $100 \mathrm{~mm}$. Excepcionalmente, durante as grandes tempestades, a lämina d'ägua que cai pode ser enorme, chegando a mais de $150 \mathrm{~mm}$ em 24 horas.

0 pluviómetro de Santa $\mathrm{Fe}$ acusou $2074 \mathrm{~mm}$ de chuva para o ano de 1974 e $1277 \mathrm{~mm}$ para 1975, o que indica grandes variações com relação à mëdia anual.

\section{B. Temperatura}

A temperatura mēdia anual è de cerca de 2509 , com um mäximo absoluto de 39,400 e um minimo absoluto de 4,0. $\mathrm{C}$. As temperaturas médias mensais, sempre superiores a 210 C, não variam mais de 50̣C, o que caracteriza um regime de isotermia. 0 mês mais frio do ano ẽ julho, com temperatu ra mēdia de aproximadamente $22 \% \mathrm{C}$, e no mês mais quente, setembro, a temperatura mëdia chega a cerca de 2700 .

No inverno, a temperatura mëdia $\overline{\mathrm{e}}$ de $240 \mathrm{C}$ e 
no verão de 250 C. Portanto, as temperaturas mëdias não permi tem a distinção entre as duas estaçöes, sendo que a grande diferença entre elas reside na variação da amplitude tërmica mäxima no decorrer do mës. Assim, nos meses de verão, a variação entre a temperatura mīnima e a māxima ē, em mēdia, de $160 \mathrm{C}$, enquanto que, no inverno, chega a quase $220 \mathrm{C}$.

Um refinamento da classificação de Koeppen coloca o clima da região de Santa Fë na categoria Awgi, o que significa clima ümido tropical (A), de inverno seco (w), com o mès mais quente anterior ao solstício de verão (g) e com regime de isotermia (i).

C. Evaporação

Evaporam-se anualmente, em mëdia, cerca de $1300 \mathrm{~mm}$ de ägua. Essa evaporação tambëm distribui-se irregularmente durante os 12 meses, sendo maior no inverno (2/3) e menor no verão $(1 / 3)$.

A evaporação è uma grandeza inversamente pro porcional à umidade do ar. Assim, nos meses de verão, a umi dade do ar è maior e nos meses de inverno è menor. Isto $\overline{\bar{e}}$ devido ao fato de no inverno chover bem menos que no verăo, para temperaturas mëdias muito pröximas entre as duas estações.

As rochas ultrabäsicas de Santa Fë estão,por tanto, no presente, submetidas à ação de um clima ümido e quente, caracterizado por pluviosidade abundante a major parte do ano, e por uma temperatura mëdia sempre superior a 210 C. Isto não quer dizer que os produtos da alteração meteōrica reflitam apenas estas condições. Antes, testemunham toda uma histöria evolutiva que se desenrolou, em parte,sob a ação de paleoclimas diferentes. 
4. Relevo

A. Aspectos Gerais: compartimentação regional e geomorfó gēnese

A região de Santa $F \vec{e}$ pertence à unidade morfoestrutural do Sudoeste goiano denominada "Depressäo de Araguaia" (Moreira 1977). Trata-se de uma extensa ārea de sedimentação cenozōica, com altitudes mëdias em torno de 300 a $400 \mathrm{~m}$. Sob o aspecto morfolōgico, ē uma vasta superfície aplainada, formada por rochas prē-cambrianas mascaradas por uma acumulação cenozöica, responsävel por uma fisionomia de terraços ou platôs escalonados em diversos nîveis, re lacionados às diferentes fases de deposição,e, ainda, por uma planīcie aluvionar quaternāria, tambēm escalonada.

Esta peneplanïcie limita-se a leste com o ma ciço goiano que, modelado em rochas do embasamento, sofreu sucessivos ciclos de denudação que acabaram por liquidar as velhas estruturas prê-cambrianas. Na região de santa $\mathrm{Fe}$, o maciço goiano apresenta-se arrasado, com altitudes de 280 a $500 \mathrm{~m}$, emergindo, apenas, como relevos residuais, os quart zitos do grupo Araxā (Serra Dourada, 800 a $850 \mathrm{~m}$ ). Para oeste, o Prë-Cambriano $\vec{e}$ fossilizado pela sedimentação holocénico-pleistocēnica do rio Araguaia, em altitudes inferiores a $200 \mathrm{~m}$.

0 terceiro elemento morfoestrutural presente, limite sul da depressão do Araguaia, $\overrightarrow{\mathrm{e}}$ a borda setentrional da bacia do Paranä. Estudada, entre outros, por Almeida 1948 e Ab'Saber e Costa Jr. 1948, è composta por sedimentos devonianos e permo-carboniferos e e marcada por um vasto alinhamento de cuestas esculpidas nas formações paleozōi cas. As frentes das cuestas voltam-se para o exterior da ba cia e o reverso constitui o planalto mesozöico do rio Verdé, retalhado pelos afluentes do Paranaiba. 0 planalto paleozói co do Bonito, na depressão periférica, com altitudes de 600 
a $800 \mathrm{~m}$, extende-se atê 0 alto da Serra Negra, formada por falhas que marcam o fim dos afloramentos da bacia. 0 planalto do Bonito ou da Caiapōnia ē recortado por rios, em sua maior parte, tributärios do Araguaia, havendo, no entanto, exceções, como o rio claro, que atravessa a Tinha de cuestas e desägua no Paranaïba.

Baseado no trabaiho de King 1957, Braun, em 1971, mostrou que no Centro-0este brasileiro, a leste de Brasilia, predominam os remanescentes da superficie sul-americana, cuja fase de agradação deu-se no Terciārio inferior. 0 prolongado periodo erosivo deste ciclo teria corta do os sedimentos Bauru e Serra Negra, nivelando indistintamente rochas da mais variada dureza e exumando as rochas alcalinas cretäceas. Os solos da extensa planicie sul-americana sofreram uma profunda e generalizada laterização.

Com o soerguimento do continente, no fim do 01 igoceno, iniciou-se o ciclo velhas, desmantelando a anti ga superficie e desenvolvendo uma nova, embutida nos inter valos rebaixados dos restos da anterior. Formaram-se, então, amplas äreas planas, condicionadas aos talvegues das principais drenagens, como no caso do interflūvio Tocantins-Araguaia, dominado pelo suave relevo da superficie ve Thas.Esta, produto de um ciclo que não chegou à maturidade, vem sendo desnudada, dando origem a paisagens do tipo das planicies aluviais quaternärias mais baixas do rio Araguaia.

B. Relevo Local: caracterização topogräfica e evolução

0 maciço de Santa $F \vec{e}$ destaca-se na paisagem atravës de testemunhos de erosäo, constituĩdos por uma dezena de morrotes espalhados a norte, e por um espigão contīnuo a sul, conhecido como Serra do Tira-Pressa. Os morro tes, de altitudes variāveis de 500 a $570 \mathrm{~m}$, possuem cumes mais ou menos ponteagudos, onde aflora a rocha quase 
fresca. A Serra do Tira-Pressa, intensamente silicificada, $\bar{e}$, de modo geral, mais elevada, apresentando pequenos platōs alçados a altitudes de ate $650 \mathrm{~m}$. Os morrotes e a serra emergem de uma superficie arrasada que merguiha suavemente para NW, em direção ao rio Araguaia, recortada pela drenagem atua 1.

A figura 4 esquematiza a evolução do relevo na ärea de Santa $F \bar{e}$. A intrusão ultramäfica deu-se no cretāceo superior, tendo sido exumada por ocasião da peneplani zação generalizada do ciclo sul-americano, no Terciärio inferior. Durante um periodo de estabilidade, sob a influência de um clima provavelmente mais seco que o atual (Moreira 1977), foi intemperizada. Na base dos perfis de alteração então formados, desenvolveram-se irregularmente considerä veis espessuras de material silicificado. Posteriormente, em clima mais ümido, sofreu laterização.

Com o inicio de um novo ciclo geomörfico, Ve Thas, no Terciārio superior, a superficie Sul-americana foi desmantelada, restando apenas relevos residuais silicificados. Na fase de agradação do ciclo Velhas, jā no Quaternärio, formou-se uma nova superfïcie embutida nos restos da primeira. A laterização voltou a atuar, formando espessos perfis e couraças ferruginosas sobre a superficie velhas, e implantando-se, de maneira incipiente, por debaixo dos cumes silicificados. A atual fase erosiva vem degradando a su perficie Velhas, que se encontra toda entalhada pela drenagem. Parte do relevo residual sut-americano foi erodido, o perfil do solo decapitado, restando morrotes e encostas onde aflora a rocha quase fresca. Outra parte, decerto mais intensamente silicificada, permaneceu, formando a serra do Tira-Pressa. Cobrindo a superfície Velhas em curso de degra dação, encontram-se a couraça ferruginosa mais ou menos des mantelada e restos silicificados provenientes dos topos.

Assim, a superfície da qual emergem os morro. 


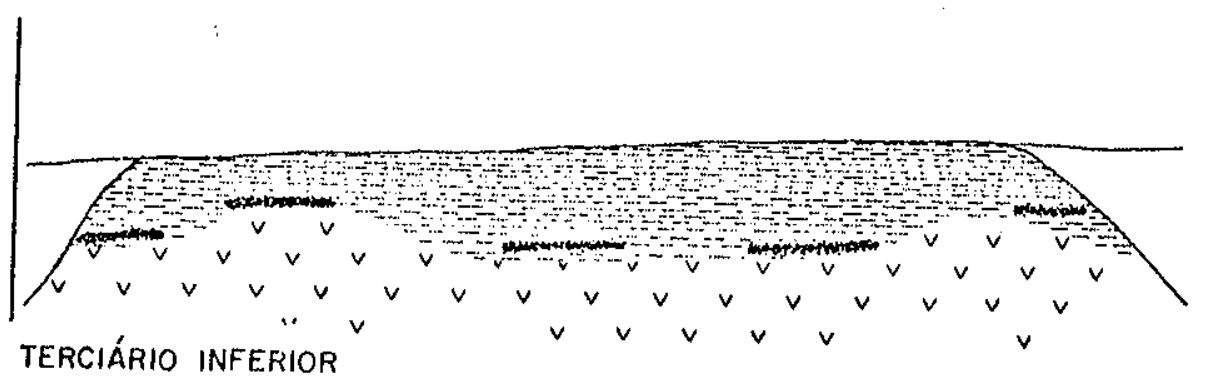

TERCIÁRIO INFERIOR

Agrodoço do superfície Sul - Americano.

Exumacóo dos ultrabósicos.

Loterizoço e silicificaçóo.

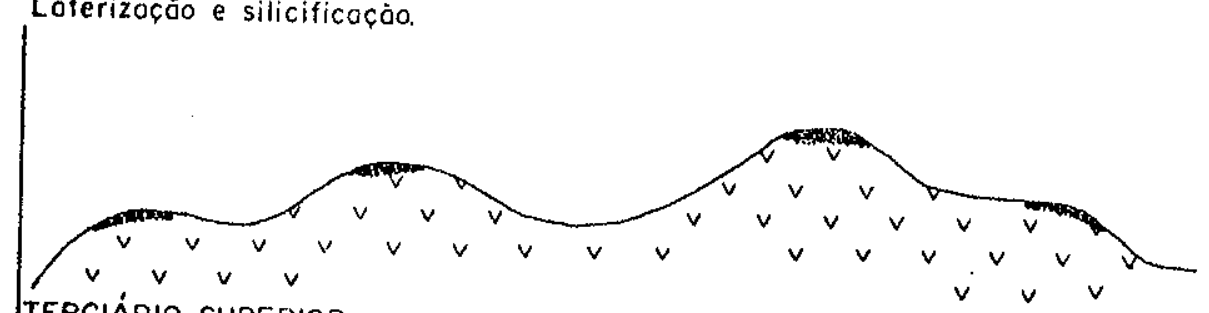

ITERCIÁRIO SUPERIOR

Início do ciclo Velhos.

Desmontelamento da superfície Sul-Americono.

Formoçỏo de relevos sustentodos pela silicificoçó.

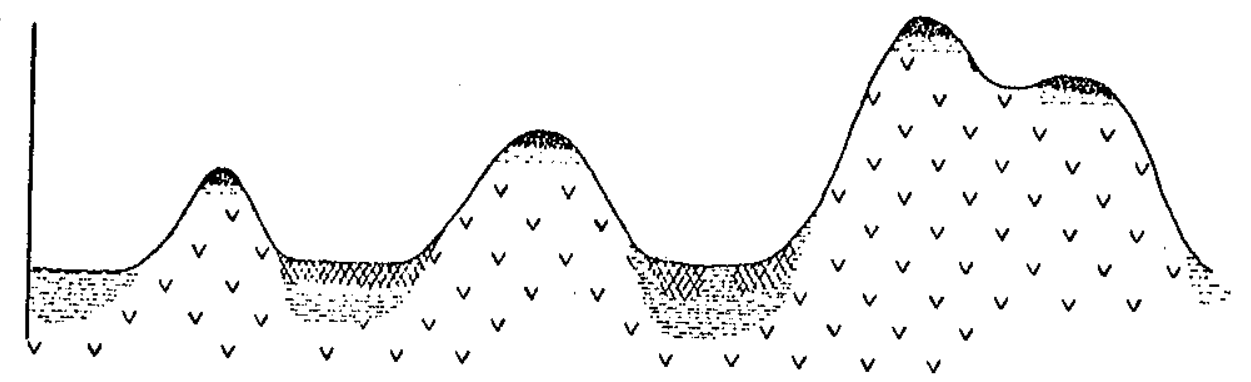

QUATERNÁRIO INFERIOR

Agrodoçōo do superficie Velhos

Loterizoçóo e encouraçomento

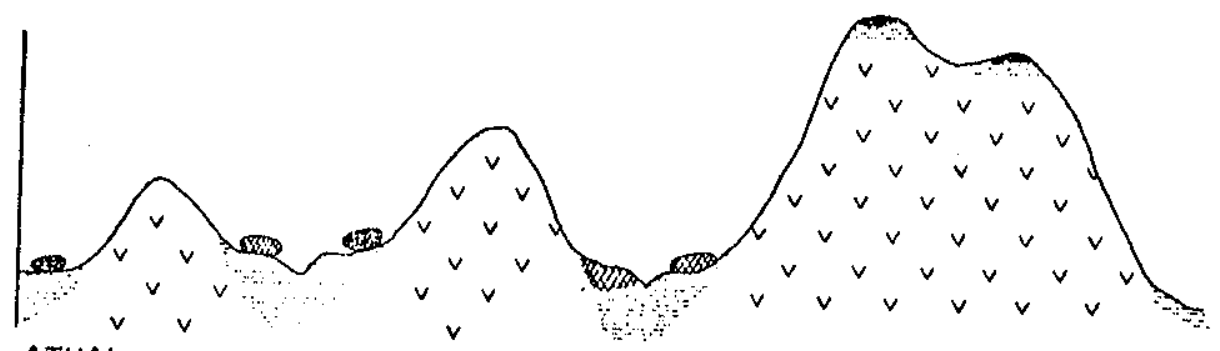

AT.UAL

Erosőo de olguns picos silicificodos (morrotes).

Permanéncio de outros (Tirn Presso)

Entolhomento do superficie Velhos: desmantelamento das couroças.

\section{LEGENDA}

\begin{tabular}{|c|c|}
\hline$\left[\begin{array}{ll}v & v \\
2 & v\end{array}\right]$ & $\begin{array}{l}\text { Serpentinito } \\
\text { Materiol silicificodo }\end{array}$ \\
\hline
\end{tabular}

Fig. 4 - A EVOLUCĀO DO RELEVO 
tes do maciço de Santa $F \vec{e}$ tem sua origem relacionada ao ci clo Velhas. 0 relevo residual corresponde a restos disseca dos da superficie Sul-americana, da mesma forma que outros testemunhos existentes na ārea, a altitudes semelhantes, tais como a Serra de São João, Lambari, Santa Rita e Agua Branca (Lessa Sọ et $a l, 1971$ ). Esta ültima emerge da pajsagem ao norte de Santa $F \bar{e}$ como uma mesa de topo plano, co berta por uma espessa camada de silexito.

\section{Vegetação}

Segundo as obras de caräter geral sobre a vegetação do Centro-0este brasileiro, como, por exemplo, Kuhlmann 1960, esta região pertence ao dominio fitogeogra fico do cerrado. Sua fisionomia $\bar{e}$ variävel, surgindo ora com ärvores de 8 a $10 \mathrm{~m}$ de altura, pröximas umas das outras, com aspecto de floresta, ora com arbustos de 2 a $3 \mathrm{~m}$ de altura, muito espaçados entre si. Apesar dessas variações, è caracterīstica comum às ärvores do cerrado possuirem troncos e galhos retorcidos, folhas grandes e coriāceas e raizes profundas, atingindo, às vêzes, mais de $20 \mathrm{~m}$. De altura bem menor que este estrato arbustivo, um estrato herbäceo, formado geralmente por graminneas de 30 a $50 \mathrm{~cm}$ de altura, cobre todo o solo.

Assim, na região de Santa Fë, o cerrado domina a paisagem, sendo adensado apenas ao longo do cursos d'água, constituindo as matas-galerias. Aî, por causa da umidade mais constante, a vegetação e favorecida, desenvol vem-se ärvores de porte mëdio, e as ervas são mais cerradas e exuberantes.

Não foi notada nenhuma diferença significativa na vegetação que cresce sobre as rochas ultrabāsicas serpentinizadas. Entretanto, os teores anormalmente eleva 
dos de $\mathrm{Mg}, \mathrm{Ni}$ e $\mathrm{Co}$ e a pobreza em $\mathrm{Al}$, Ca e nos macronutrien tes $N, P$ e $K$ nos solos que sobre elas se desenvolvem pode riam causar diferenciação nos vegetais conduzindo ao aparecimento de formas adaptativas (Brooks 1972).

Sö um estudo fitogeogräfico e biogeoquïmico de detalhe traria informações a respeito deste problema, o que estā alēm dos objetivos deste trabalho. 
CAPITULO II

ESTUdO MINERALOGICO E GEOQUIMICO DOS PERFIS DE ALTERAÇAO

\section{Os Perfís Estudados}

Foram estudadas dezenas de perfis de alteração sobre dunito, peridotito e piroxenito, a maior parte dos quais alinhados segundo o plano de amostragem estabelecido pela Montita Mineradora Ltda., em sua fase de pesquisa da jazida. Com relação a alguns, reconstruiu-se a distribui ção espacial dos fācies de alteração, a partir das descrições de campo efetuadas pelo geōlogo da Mineradora, por ela gentilmente cedidas (topossequencias XV, E6 e E10). Acompanharam estas descrições dados quĩmicos das amostras re tiradas dos poços dispostos segundo as topossequências XV E6.

Outros perfis foram cuidadosamente seleciona dos, descritos, amostrados e estudados em pormenor, tanto do ponto de vista mineralógico como geoquímico. E o caso dos perfis sobre as toposseqliências XXVII e W4, bem como os dos poços denominados Pe, Py, G e C. A escolha obedeceu ao critērio da procura de perfis dispostos segundo topossequén cias (XXVII e W4), sobre litologias distintas (poços Pe e Py) e, finalmente, perfis que evidenciassem peculiaridades no processo de alteração (poços G e C). A localização dos poços no maciço ultrabásico consta da figura 2 .

Além das amostras dos diversos horizontes de perfis de alteração, foram tambëm coletadas amostras esparsas de materiais que despertaram interesse especial, tais como blocos de howwork silicoso, veios de vermiculita, con- 
centrações de garnierita, etc. Foram ainda estudadas amostras de rocha fresca ou quase fresca, provenientes de furos de sondagem.

A. Topossequẽncias XV, E6 e E10

As topossequēncias XV, E6 e E10, todas sobre dunito, cortam o maciço em regiões de baixada (declives mäximos de 3/100), nas direções aproximadas de NE-SW,NS e NS, respectivamente. A toposseqüencia $x V$, situada na porção cen tro-oeste, com $2700 \mathrm{~m}$ de comprimento, abrange 25 poços de profundidade variävel entre 2 e $20 \mathrm{~m}$, distanciados entre si por cerca de $100 \mathrm{~m}$. As toposseqüéncias paralelas E6 e E10, prōximas ao limite leste do maciço, medem cerca de $2000 \mathrm{~m}$ ca da uma, compreendendo, com espaçamento regular, 15 poços de 3,5 a $13 \mathrm{~m}$ de profundidade e 17 poços de 4,5 a $11 \mathrm{~m}$ de profun didade, respectivamente.

\section{B. Topossequēncias XXVII e W4}

A topossequência XXVII, de $2200 m$ de extensão, corta o maciço em sua porção centro-oeste, na direção NE-SW. Localiza-se no nūcleo do maciço, em pleno domīnio du nitico, e atravessa topografia bastante acidentada, sendo 0 desnīvel mäximo de $100 \mathrm{~m}$. Foram estudados perfis de altera ção em 13 poços de profundidade variāvel entre 1 e 4,5m, si tuados em diferentes posições topogräficas, a saber:

- topo (cumes ou pequenos platôs)

- encosta (declives da ordem de 30/100)

- sopé (declives da ordem de 8/100 a 5/100)

- baixada (declives da ordem de 3/100)

A toposseqüência W4, com direção NS e locali 
zada na porção SE do maciço, mede $450 \mathrm{~m}$ e abrange 4 perfis, dos quais 3 sobre dunito ( $S 8,511$ e $S 12+50)$ e um sobre peri dotito (S10). Situa-se ao pe do morro do Tira-Pressa e sua declividade mëdia $\vec{e}$ de 5/100. Os perfis variam em profundidade de 6 a $10 \mathrm{~m}$.

\section{Perfis Pe e Py}

São perfis descritos em poços situados nas bordas do maciço, sobre os anēis de peridotito e piroxenito. 0 perfil Pe, numa mancha peridotitica a oeste, tem $3,4 \mathrm{~m}$ de profundidade. O perfil Py, no limite $N$, atinge $10 \mathrm{~m}$.

D. Perfis G e C

O perfil G foi escolhido por ser especialmen te rico em $\mathrm{Ni}$, cujos minerais, de um verde brilhante, mancham toda a rocha e os materiais alterados. Situa-se sobre dunito, no alto de um morro, conhecido como Morro do Nĩquel, e atinge $6,2 \mathrm{~m}$ de profundidade.

0 perfil C localiza-se na encosta de um morrote extremamente silicificado, na borda leste do maciço. Chega a $9 \mathrm{~m}$ de profundidade, e atravessa material quase que totalmente composto por calcedónia e quartzo.

\section{A Evolução Mineralögica}

A. Os Fäcies de Alteração sobre Dunito

a. 0 perfil completo

Apesar de não se poder falar em perfil-tipo, jă que a disposição, bem como a espessura dos diferentes fá 
cies de alteração,varia muito,em função principalmente da posição topogrāfica do perfil, cabe considerar o que seria um perfil completo. Este, apesar de ser uma entidade teöri ca, estā presente, de fato, em sĭtios favorāveis ao seu de senvolvimento e preservação.

Assim, o perfil de alteração dos dunitos dé Santa $F \vec{e}$ consta, a partir de sua base, dos seguintes horizontes (figura 5 ):

- rocha fresca $(R)$ : dunito serpentinizado;

- rocha dura (RD): rocha coesa, mostrando, ao microscōpio, os primeiros siriais de alteração supërgena;

- saprolito grosso (SG): material rochoso mais alterado que o anterior, de estrutura conservada, mas de coesão reduzida;

- Taterita* amarela (LA): material saprolitico amarelado de textura mais fina que o $S G$, friävel, porëm conservando a estrutura da rocha;

- laterita vermelha (LV): solo vermelho com frequentes con creções ooliticas e pisoliticas, localmente soldadas em crosta.

A rocha fresca, de densidade em torno de 2,8, variando com o grau de serpentinização, nunca foi encontrada em poços. Aparece em amostras de furos de sondagem, a profundidades superiores a $20 \mathrm{~m}$. A rocha dura (dens $\underline{i}$ dade aparente entre 1,7 e 2,5$)$ ocorre atē uns $5 \mathrm{~m}$ de profundidade, em mëdia, passando gradualmente, a partir da $\vec{i}, a$ saprolito grosseiro. A espessura deste horizonte, cuja den sidade varia de 1,8 a 1,3 , pode chegar a 3 ou $4 \mathrm{~m}$. As faixas de laterita amarela, estreitas e descontinuas, alcan-

* Neste caso,laterita ē um termo de campo e não corresponde rigorosamente a laterita sensu strictu. 


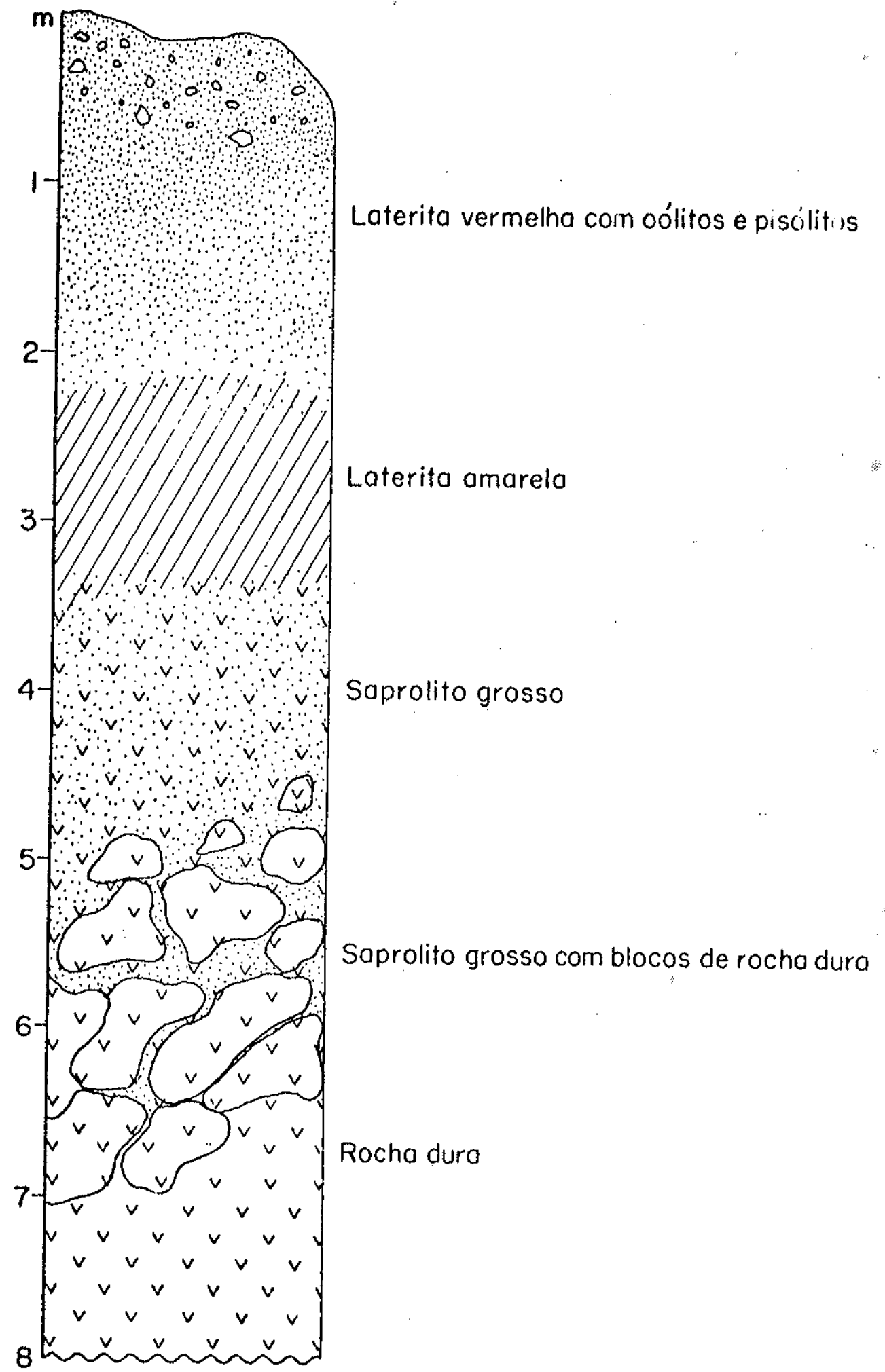

Fig. 5 - PERFIL DE ALTERAÇÃO SOBRE DUNITO 
çam, no mäximo,2m. E um material poroso, de densidade ao re dor de 1,2. Uma camada de laterita vermelha, de espessura variāvel de 0,5 a $4 \mathrm{~m}$, está presente no topo de todos os perfis.

b. A composição e a estrutura dos horizontes de alteração b.1. Descrição macroscōpica

A rocha fresca è um dunito serpentinizado, fraturado, de cor que varia de preto a verde escuro, cortado, com muita frequência, por veios milimëtricos de um mate rial de cor branca ou amarelada. Os primeiros sinais de alteração começam a aparecer ao longo das diāclases, onde a rocha perde um pouco de seu brilho. Com o decorrer do processo, ela pode assumir uma cor mais acinzentada, embora, na maior parte das vezes, a distinção entre a rocha fresca e a chamada "rocha dura" sō possa ser feita ao microscōpio.

Cortando a rocha dura e ocupando suas fraturas, aparecem depōsitos de alguns milimetros de espessura, chegando atë $2 \mathrm{~cm}$, de um material verde mais ou menos argiloso e rico em $\mathrm{Ni}$, cuja denominação de campo ē "garnierita".E tambëm a partir deste horizonte que começam a aparecer os vejos de quartzo.

0 saprolito grosseiro ainda guarda o aspecto de rocha, porēm jă $\vec{e}$ mais friāvel, deixando-se esmagar pelas mãos. Conserva perfeitamente a estrutura do material original, mas muda de cor, tornando-se marron amarelado, sem britho. A alteração prosseguindo, as bordas dos blocos de saprolito grosseiro vão passando a um material mais poroso e mais claro. Assim, em direção ao topo do perfil, encontram-se cada vez menos blocos de saprolito, de tamanho pro gressivamente menor, mergulhados num material pulverulento amarelo. Quando hä predominio deste material, caracteriza- 
se o horizonte de laterita amarela. Este $\bar{e}$ um material sapro lïtico fino, sem coesão, embora nele ainda se possa reconhecer a estrutura da rocha. 0 nível de laterita amarela ē, em geral, pouco espesso, podendo, muitas vezes, não existir. E no topo do horizonte de saprolito grosseiro e na transição para laterita amarela que aparecem as maiores concentrações de $\mathrm{Ni}$ do perfil.

Por fim, uma laterita vermelha, de espessura variävel entre menos de $50 \mathrm{~cm}$ nos topos ate 3 a $4 \mathrm{~m}$ nas baixadas, representa o $\bar{u} 1$ timo horizonte do perfil. Neia, o volume do material original não è mais conservado, havendo compactação e possĩvel remanejamento. 0 material é pulverulento, comportando, na maioria das vezes, concreções sub-milimetricas de alta suscetibilidade magnētica. São os oōlitos e pisö litos, que, quando cimentados, formam crostas.

\section{b.2. Distribuição granulomëtrica}

As amostras da topossequēncia w4 foram submetidas a anälise granulomētrica em 4 frações: $\phi>2 \mathrm{~mm}, 2 \mathrm{~mm}>\phi>$ $0,25 \mathrm{~mm}, 0,25 \mathrm{~mm}>\phi>0,062 \mathrm{~mm}$ e $\phi<0,062 \mathrm{~mm}$. 0s resultados estão apresentados na figura 6 .

Admite-se geralmente que o intemperismo tem como efeito a diminuição da granulometria do material, levan do, assim, a uma concentração de finos nos fäcies mais alterados. De fato, isto ocorre na passagem $R D \rightarrow S G \rightarrow L A$, sendo que, a partir do $S G$, as frações mais grossas deixam de predo minar, e a laterita amarela fica enriquecida em finos. Esta tendência é, entretanto, revertida, quando se passa para a laterita vermelha. Isto pode ser explicado pelo concrecionamento, frequente nesse horizonte.

A figura 6 resume os dados da distribuição granulomëtrica em um diagrama triangular, cujos vërtices säo 


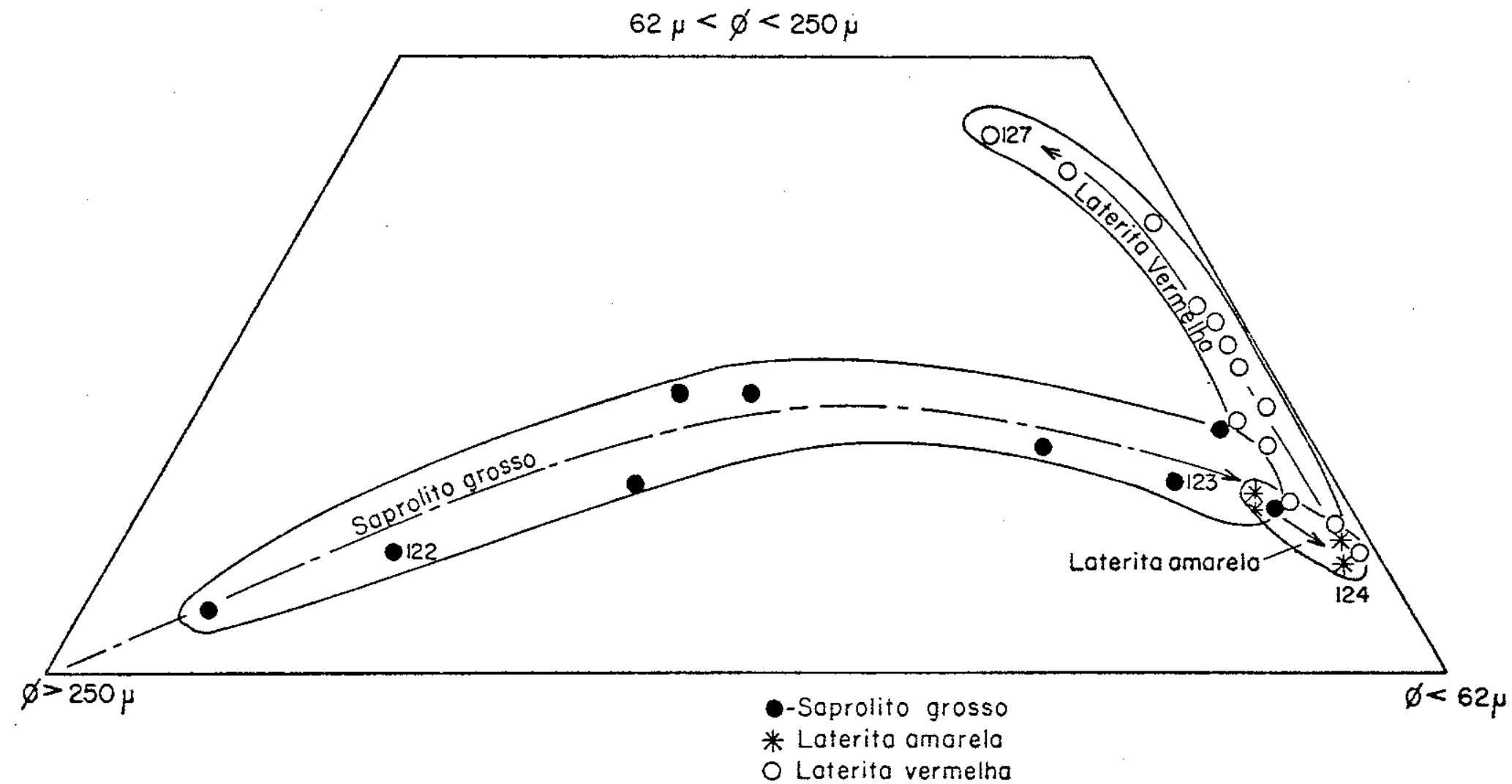

Fig. 6 -EVOLUÇÃO DA DISTRIBUICÃO GRANULOMÉTRICA DURANTE A ALTERACĀO

(Amostras da topossequencio W4) 
ocupados, respectivamente, por $100 \%$ da fração mais grosseira (soma de $\phi>2 \mathrm{~mm}$ e $0,25<\phi<2 \mathrm{~mm}$ ), $100 \%$ da fração intermediäria $(0,062<\phi<0,25 \mathrm{~mm})$ e $100 \%$ da fração fina $(\phi<0,062)$. A linha que mostra a tendēncia geral de evolução de RD para $S G$ indica que, no decorrer do processo, as partículas de tamanho major vão dando lugar, simultaneamente, aos finos e às de tamanho intermediārio. Estas, no entanto, nunca chegam a predominar, sendo a tendëncia da LA unicamente em direção aos finos. Isto è reflexo de uma inicial permanēncia de alguns silicatos primärios no fäcies $S G$ e de seu quase total desaparecimento no estāgio seguinte (LA). Nesta figura,fica evidente a evoluçăo da LV a partir de particulas fi nas, no sentido da aglutinação em concreções de tamanho intermediärio e grosseiro. Ausentes nesse diagrama, porëm pre sentes em certos trechos de baixada,estäo as carapaças de Fe, intensamente cimentadas, o que significa um retorno na evolução granulomëtrica ao polo @ $250 \mathrm{~mm}$.

Os mesmos traços gerais na evolução do tamanho das particulas de material proveniente da alteração das rochas ultrabäsicas jä haviam sido constatados por Zeissink 1969 e Trescases 1975 .

c. Caracterização mineralógica dos fảcies de alteração

Para a realização deste estudo, foram utiliza das as tēcnicas de difração de raios $x$, anālise termo-diferencial, exame ao microscōpio polarizante e à lupa binocular, cujos detalhes estão descritos no Apêndice II. o material analisado foi sempre a amostra total e, quando possivel e conveniente, certas frações granulomëtricas e/ou mine ralögicas foram tambëm investigadas. A tabela 5 resume a composição mineralōgica de cada fäcies de alteração.

c.1. Rocha fresca: dunito serpentinizado

Jä caracterizada a rocha do ponto de vista 


\section{TABELA 5}

AVALIAÇAOO SEMI-QUANTITATIVA DOS MINERAIS PRESENTES NOS FACIES DE ALTERACAO SOBRE DUNITO SERPENTINIZADO

$R \quad$ RD $\quad S G \quad L A \quad L V$

\begin{tabular}{|c|c|c|c|c|c|}
\hline olivina & ++ & + & $(+)$ & - & - \\
\hline piroxênio & $(+)$ & $(+)$ & - & - & - \\
\hline cromita & + & + & + & + & $+t$ \\
\hline carbonato & + & $(+)$ & - & - & - \\
\hline brucita & $(+)$ & - & - & - & - \\
\hline vermi-clorita & + & + & + & + & $+(+)$ \\
\hline magnetita & + & + & + & + & ++ \\
\hline serp I & $+t+$ & $++t$ & $+t$ & + & - \\
\hline serp II & + & + & $(+)$ & - & - \\
\hline esmectita & - & $(+)$ & + & $(+)$ & - \\
\hline goethita & - & - & $(+)$ & + & $(+)$ \\
\hline hematita & - & - & - & - & + \\
\hline quartzo & - & + & + & + & $+t$ \\
\hline "talco" $10 R$ & - & + & + & - & - \\
\hline
\end{tabular}

+++ abundante

+ frequente

$+\quad$ escasso

(+) traços

- ausente 
textural, modal e quīmico no capitulo I, passar-se-āa à descriçăo pormenorizada de cada componente mineralögico. os 3 primeiros minerais descritos têm sua gênese relacionada à intrusão da ultrabāsica,e os demais ao processo de serpenti nização hipögeno.

\section{Olivina}

Os cristais de olivina apresentam-se como grãos anedrais de granulação mëdia, intensamente fraturados; com clivagem (100) bem preservada. São opticamente positivos, o que indica seu caräter magnesiano. Constituem um resĩduo do processo de serpentinização e porisso encontram-se intimamente associados a seus produtos. Assim, os cristais de olivina ocupam sempre o centro de um reticulado poliëdri co de serpentina; o contato entre esses dois minerais dä-se muitas vezes atravess de uma fina camada de carbonato.

\section{Piroxënio}

ocorrendo em quantidades muito reduzidas, ou totalmente ausentes, os piroxënios tambēm podem encontrar se parcialmente serpentinizados. São monoclínicos, de cor castanho clara, bem clivados, com extinção a 450. Pertencem à sërie diopsîdio-salita.

\section{Cromita}

A cromita ocorre como pequenos cristais octaëdricos, eudrais a sub-eudrais, distribuidos aleatoriamen te pela rocha. Algumas vēzes mostram fraturas preenchidas por serpentina. Nos contatos cromita-serpentina, $\vec{e}$ comum o desenvolvimento de um mineral micáceo de caracteristicas in termediārias entre vermiculita e clorita. 


\section{Serpentina}

0 reticulo poliēdrico de serpentina, forma de ocorrencia mais comum deste mineral, tem um aspecto cam racterístico: é formado por duas faixas contīguas, onde os cristais do mineral dispõem-se perpendicularmente às paredes. E comum que entre essas duas bandas de serpentina ins talem-se opacos xenomorfos de magnetita ou vēnulas de carbo nato. A serpentina tambēm pode ocorrer de forma placóide, 음 cupando o lugar dos antigos nücleos de olivina, ou em plages, finamente cristalizada, associada ou não a carbonatos. $\mathrm{Na}$ hipötese destas duas variedades terem sido formadas em duas gerações sucessivas, receberão a denominação, respecti vamente, de serpentina I e II. Ocorre ainda serpentina bem cristalizada em veios, em associaçăo a carbonatos e brucita (serpentina III).

Os estudos öpticos näo são conclusivos na identificação do tipo de serpentina. Tambēm não o são os exa mes dos difratogramas de rocha fresca, à luz dos critërios de Whittaker $\xi$ Zussman 1956 e Brown 1961. As reflexöes caracterĩsticas das serpentinas de Santa Fé correspondem a distâncias interplanares de $7,25 \AA, 4,55 \AA, 3,63 \AA$, e 2,48 (fig. 7A). Faust $\xi$ Fahey 1962 mostraram que è possivel distinguir entre antigorita e o par crisotila-lizardita, por meio da anālise tërmica diferencial. Segundo os seus crite-rios, trata-se de üttima alternativa, como jā foi indicado por Barbour 1976. Pode-se dizer, portanto,que os principais minerais de serpentina aqui presentes são a crisotila e a lizardita, caracterizadas por um forte pico endotērmico no intervalo 670-6900 C, um exotērmico entre 800 e $8200 \mathrm{C}$, e um pico fraco e largo a baixas temperaturas, da ordem de $120.0 \mathrm{C}$ (fig.7B).

Magnetita

Entre os opacos, estā presente a magnetita, 


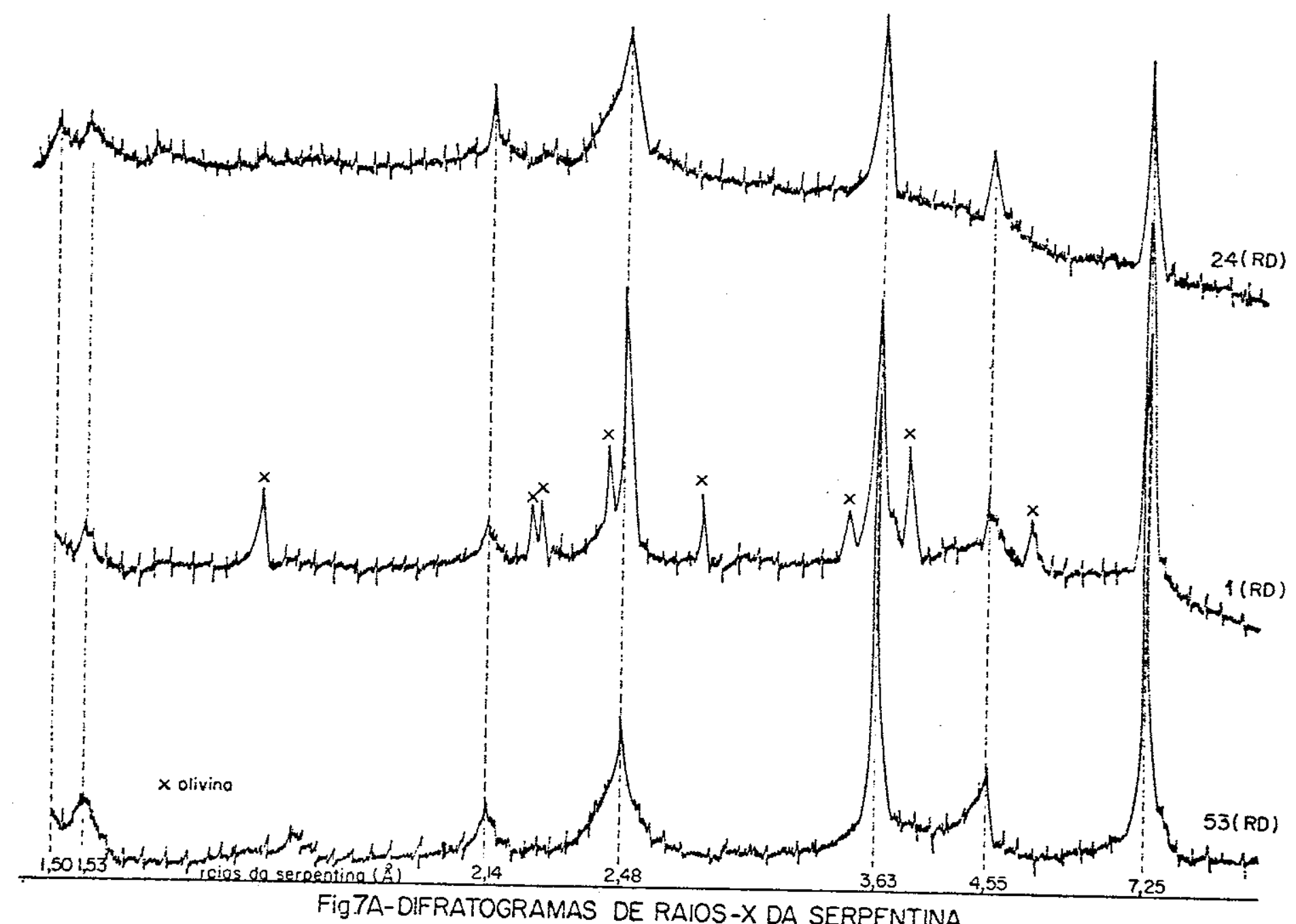




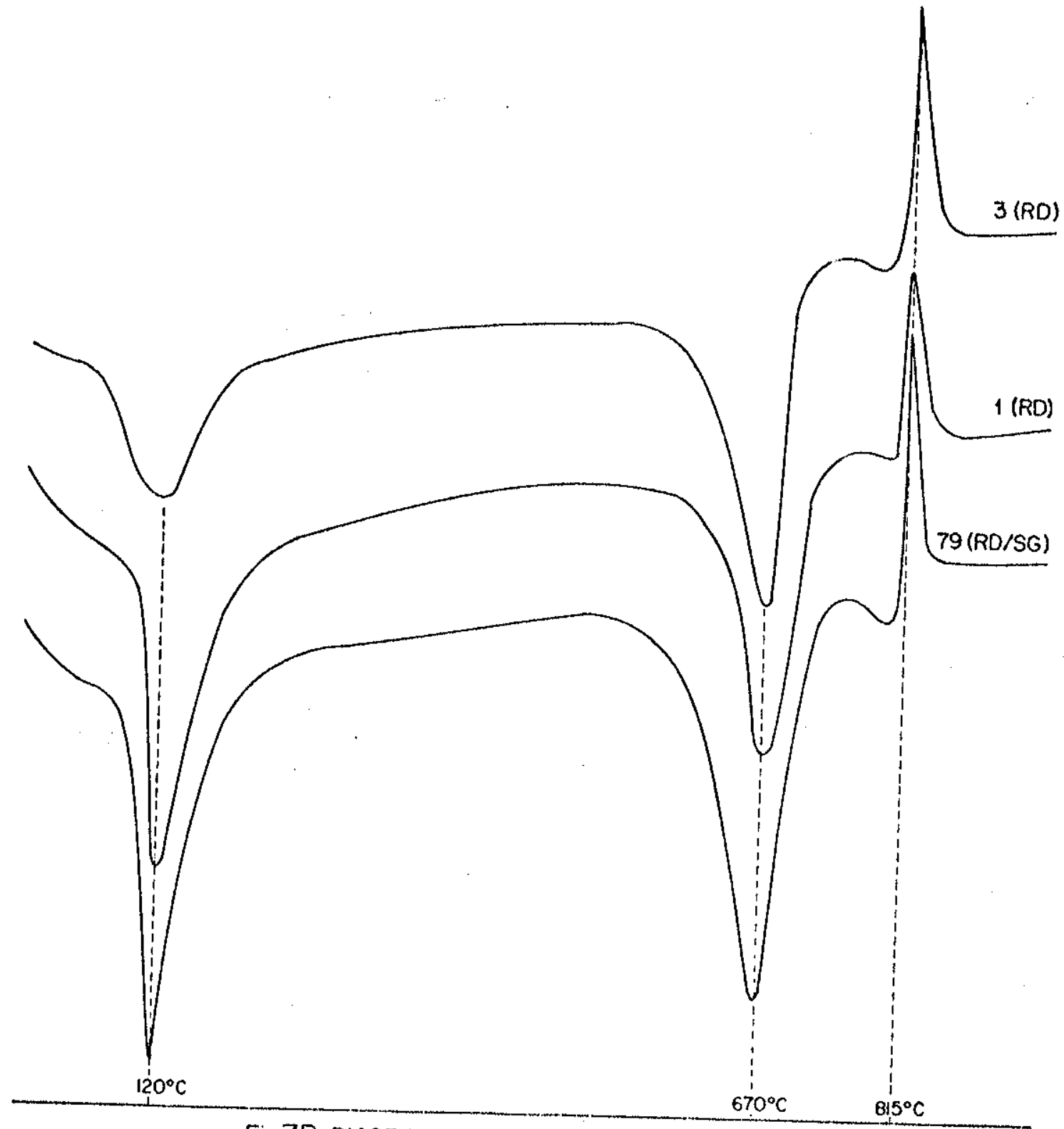

Fig.7B-DIAGRAMAS DE ATD DA SERPENTINA 
que se distingue da cromita por se apresentar xenomorfa,em grãos menores, distribuida em cordões entre os pacotes de serpentina. Sua gênese relaciona-se ao processo de serpentinização, como jă foi discutido no capĩtulo I.

\section{Mineral micäceo}

Associado aos cristais de cromita, espalhados aleatoriamente na rocha ou concentrados em veios, exis te um mineral que, em geral, assume aspecto tipico de vermiculita (pardo, pleocrōico, padrão difratomētrico caracte rĩstico), mas, que, às vēzes parece clorita (esverdeado e comportando-se aos raios $x$ com manutenção do pico a $14 \AA$, quando aquecido a 550 Q C). Quando em cristais bem desenvol vidos, geralmente associado a veios, trata-se de um mineral interestratificado de clorita e vermiculita, com predo minância do ültimo termo, e apresenta expansibilidade (Rosenburg 1972).

No caso de ocorrência disseminada na rocha ou em volta de cristais de cromita, as evidências ópticas indicam predominância ora de vermiculita, ora de clorita.A origem deste mineral deve ser relacionada ao processo de serpentinização. Soluções hidrotermais a ele relacionadas formaram,em fraturas da rocha,grandes placas de vermiculita-clorita. Essas soluções devem tambëm ter sido capazes de transformar uma mica original, provavelmente do tipo flogopita, em vermiculita-clorita. A associação caracterīs tica mineral micāceo-cromita parece resultar de uma reaçăo de borda entre a cromita original e a serpentina em vias de formaçăo.

\section{Carbonatos}

Os carbonatos formam vênulas milimëtricas, cortando indistintamente olivina, serpentina e opacos, ou 
agregados finamente cristalizados associados com serpentina. Nas vênulas, ocorrem como prismas curtos e finos, normais às paredes das fissuras. Associam-se à serpentina, crescendo en tre as faixas contĩguas, interpondo-se entre ela e a olivina, ou disseminando-se nas plages de serpentina mal cristali $z a d a$. Aos raios $x$, os carbonatos mostram picos de magnesita ou dolomita.

Alēm de ser recortada por vënulas milimētricas e submilimëtricas, a rocha fresca ē frequentemente atravessada por veios mais espessos de atē $1 \mathrm{~cm}$, cuja composição e serpentina III, carbonatos e raramente brucita (amostras F $35 / 18$ e F $27 / 18$ da figura 8 ).

\section{c.2. Rocha dura}

A rocha dura è um material marron, coeso, mas sem o brilho da rocha fresca. Ao microscópio, mostra os primeiros sinais de alteração supērgena, que se revelam pelo ata que da olivina. As bordas dos cristais dissolvem-se, deixando buracos preenchidos ou năo por uma mistura amorfa ou cripto cristalina de cor castanha, que, pelo menos parcialmente, de ve ser composta de uma argila expansiva do grupo das esmecti tas. às vêzes, o quartzo microcristalino toma o lugar da oli vina desaparecida.

0 piroxēnio, quando presente, permanece inalterado. A cromita pode mostrar as primeiras evidéncias de corrosão nas bordas, deixando buracos que testemunham sua forma original.

Em lâmina delgada, uma feição característica do iñ̃cio da alteração ē a coloração amarela generalizada as sumida pelo retīculo da serpentina I. Isto è devido à absorção de hidrōxidos de Fe provenientes da oxidação da magnetita ou da olivina hidrolisada. 


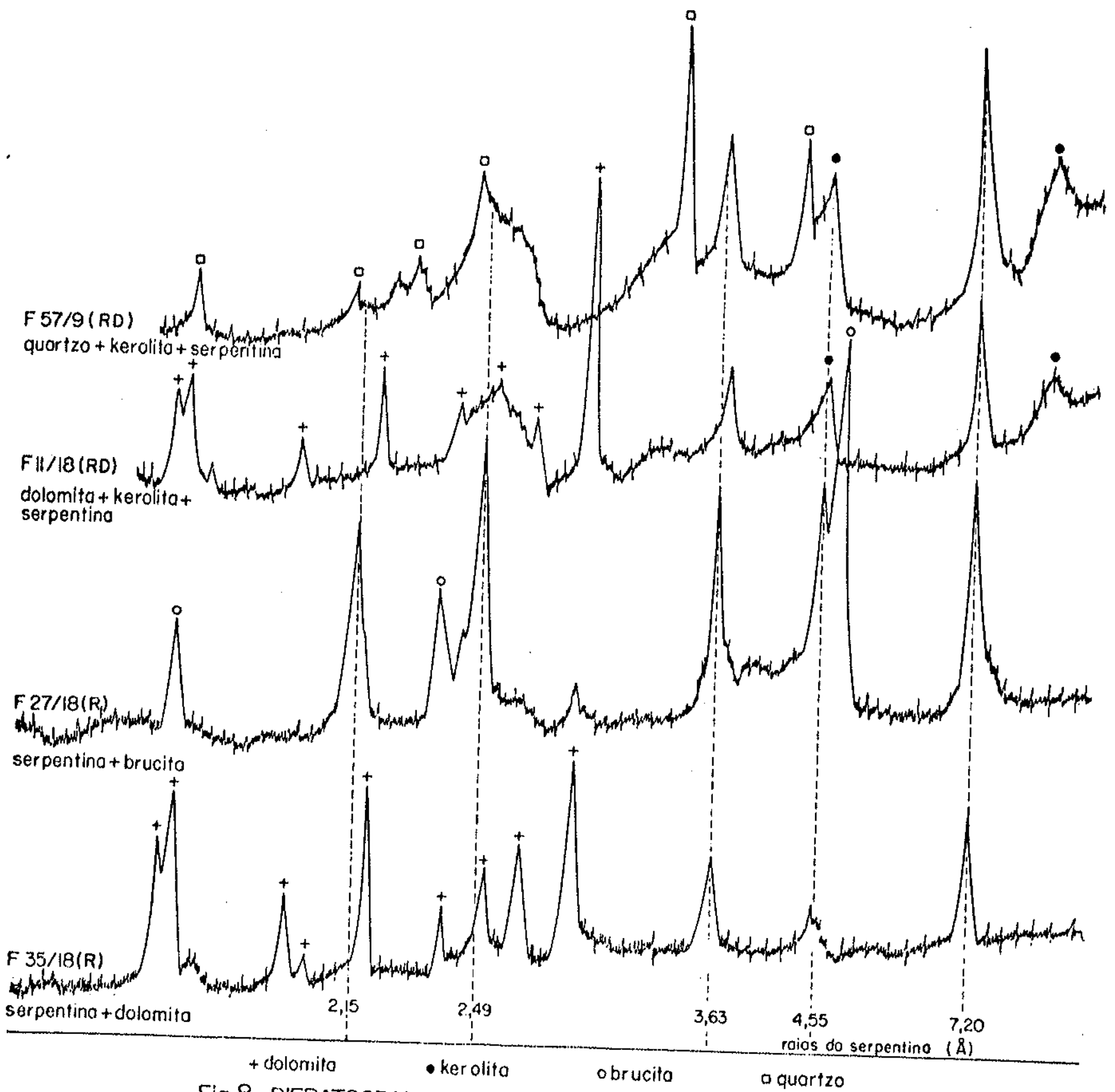

Fig.8 - DIFRATOGRAMAS DE RAIOS - X DO MATERIAL DOS VEIOS QUE CORTAM A ROCHA 
As orlas de material amorfo ferruginoso não se encontram apenas ao redor da olivina, como jä descrito, mas são tambēm muito comuns em volta da serpentina placōide (II) do centro do retĩculo, ou misturado a ela. Trata se de uma zona preferencial de acumulação de Fe devido à descontinuidade da passagem serpentina I-serpentina II.

Os carbonatos começam a sofrer dissolução que sö se completarā no estägio seguinte, permanecendo na rocha dura residualmente, com a mesma disposição original jä descrita. 0 mineral micäceo continua intacto.

\section{Esmectita}

Aparece em pequena quantidade, como produto da alteração da olivina. Sua natureza ë difícil de ser pre cisada; pois não permite separaçăo. A formação de esmectítas pela alteraçăo de olivina ē o processo dominante em climas pouco agressivos, como, por exemplo, no depösito de Asbestos (Canadä), descrito por De Kimpe G Ziska 1973.0cor re tambēm, em menor escala, sob clima tropical, na Nova Cá lodônia (Trescases 1975, Besset 1978), em Bornēo (Eswaram $\xi$ Sys 1972), na Indonësia (Kuhnel et al. 1978), etc.

\section{Quartzo}

Produto de neoformação a partir das. soluções provenientes da hidrōlise da olivina, este mineral de posita-se nas cavidades por ela deixadas e em vēnulas, cortando a rocha. Trata-se de quartzo finamente cristalizado ou de calcedōnia. Quando impregnado por Fe, a granulaçăo diminui sensivelmente, devido ao efeito inibidor do Fe com relação à cristalizaçäo da sîlica. Raramente apresenta tons esverdeados, devido à presença de $\mathrm{Ni}$ (crisoprāsio). Acumulação supērgena de quartzo por alteração de rochas uTtrabäsicas foi descrita em värios maciços do mundo, como, 
por exemplo, na Costa do Marfim(Nahon 1979), na Austrālia (Matheson 1967) e na Etiōpia (Clark 1978).

\section{Veios preenchendo fissuras}

Com o inäcio da alteraçäo meteōrica, desaparecem dos veios os traços de brucita, a serpentina III conserva-se e começam a aparecer as neoformações: quartzo e ke rolita, mineral da familia do talco, porëm mais hidratado, com distāncia interplanar característica de 10 \& aproximada mente. O carbonato conservause inicialmente, para desaparecer logo em seguida.

os veios cortando a rocha dura são,portanto, compostos de misturas de serpentina, carbonato, kerolita e quartzo, em diferentes proporções (amostras F 57/9 e F 11/18 da figura 8), dependendo do estägio de evolução em que se encontram (vide "Filiações mineralögicas"). Podem ou não ser enriquecidos em $\mathrm{Ni}$ e, neste caso, assumem cor verde caracteristica, como nas amostras 107-ve e Al-ve.

\section{c.3. Saprolito grosso}

Material ainda com certa coesão, o saprolito grosso $\vec{e}$ de cor amarelada, representando um estägio mais adiantado no processo de alteração. Neste, praticamente, não existe mais olivina, que ja foi totalmente hidrolisada, de $\mathfrak{j}$ xando os mesmos residuos descritos para a "rocha dura", porëm em maior quantidade. Assim, os amorfos ferruginosos são mais abundantes, ocupando a maior parte dos antigos nūcleos de olivina. A partir desta fase de alteração, este material amorfo começa a se cristalizar em goethita.

E neste horizonte que a esmectita aparece em maior quantidade, e de onde foi separada para anälise. 0 di 
fratograma e o diagrama de ATD da figura 9 parecem indicar que a fração fina da amostra 9 (saprolito grosso) contēm uma mistura de serpentina e esmectita, com predominância desta ūitima. O diagrama de ATD apresenta um pico endotērmico a $8450 \mathrm{C}$, caracteristica da esmectita da sërie trioctaēdrica (Chantret et al. 1971, Mackenzie 1957).

0 piroxentio e o mineral micäceo continuam $\underline{i}$ natingidos pelo processo de alteração. A corrosão que ataca a cromita continua, e a magnetita vai se tornando progressivamente avermelhada. Os carbonatos são completamente solubilizados.

No saprolito grosso, a serpentina, apesar de cada vez mais fortemente colorida, ainda permanece inal terada. Os veios brancos, que preenchem as fraturas, perma necem e são sujeitos à mesma desagregação que atinge a rocha.

Goethita

Mineral originado da cristalização dos produtos amorfos ferruginosos, a goethita começa a aparecer nesta fase da alteração, atingindo seus maiores teores no horizonte de laterita amarela.

Niveis enriquecidos em $\mathrm{Ni}$

No topo do saprolito grosso, ja na passagem para laterita amarela, as anālises quïmicas das amostras totais evidenciam um enriquecimento em $N i$. Como não foi de tectado neste horizonte de enriquecimento nenhum minera especial portador de $\mathrm{Ni}$, colocam-se algumas alternativas: 0 $\mathrm{Ni}$ pode estar no reticulo da goethita, associado aos amorfos, ou à serpentina em vias de alteração. A resposta a es sas questões somente serä possîvel aposs um pormenorizado 


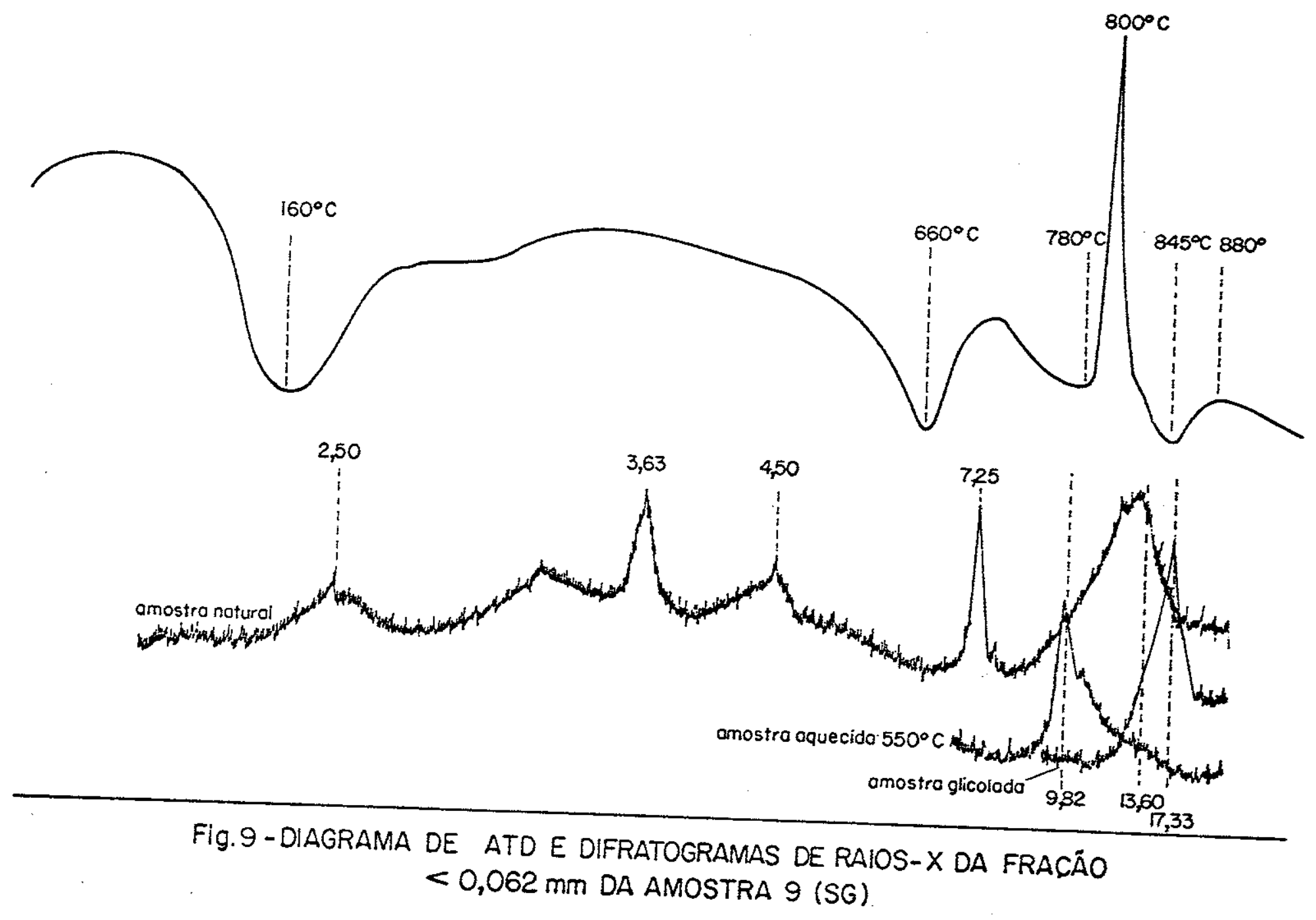


estudo quĩmico (vïde "A evolução quĩmica").

\section{c.4. Laterita amarela}

Trata-se de um material de cor marron amarelada, poroso, que ainda conserva o volume do material inicial, mas que foi profundamente destituído de sua massa. Lo calmente pode encontrar-se compactado.

Dentre os silicatos primärios, restam apenas um pouco de serpentina totalmente impregnada por Fe e os mi nerais micāceos, que mostram uma evolução incipiente para esmectita de natureza não determinada. Isto ê claramente evidenciado pelos difratogramas das fraçöes mais finas dos veios de vermiculita (fig.10), conforme jä havia sido obser vado em micas de piroxenito (01iveira $\xi$ Melfi 1978). Por ou tro lado, a esmectita formada nos primeiros estägios da alteração tende a desaparecer neste horizonte.

A cromita, por estar mais corroida, apresenta-se em grăos cada vez menores. Nesta altura, não ē mais possivel acompanhar o destino da magnetita.

A laterita amarela ē o dominio, por excelência, da goethita, que encontra condições de cristalizar- se à medida que os amorfos sofrem dessilicificação, diminuindo, desta forma, o efeito inibidor que a sïlica tem na cristali zação dos produtos ferruginosos amorfos (Melfi 1971). Este mineral não apresenta boa cristalinidade, o que ē evidencia do pelo seu comportamento à anālise térmica diferencial (fig.11). Picos endotērmicos entre 300 e $3200 \mathrm{C}$ revelam baj xo grau de organização atômica, segundo Mackenzie 1957. Por esse motivo, suas raias caracterĩsticas não são bem nĩtidas nos difratogramas (fig.11). Contudo, e possivel identificar - pico mais importante (130); este aparece sempre correspon dendo a um espaçamento entre 2,69 a $2,70 \AA$, o que indica um 


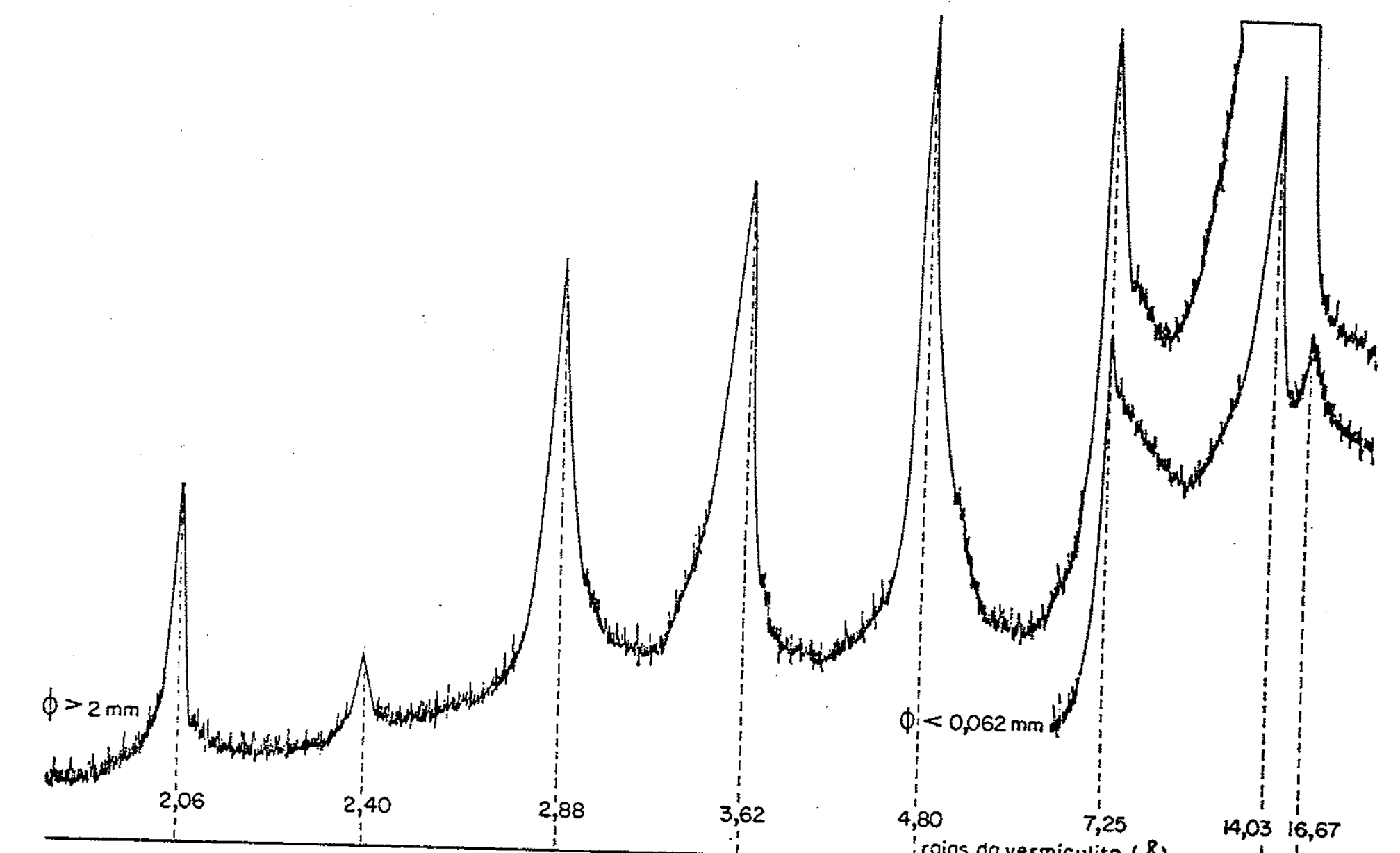

Fig.IO-DIFRATOGRAMAS DE RAIOSX PARA A VERMICULITA EM GRANDES PLACAS, ENCONTRADA EM VEIOS 

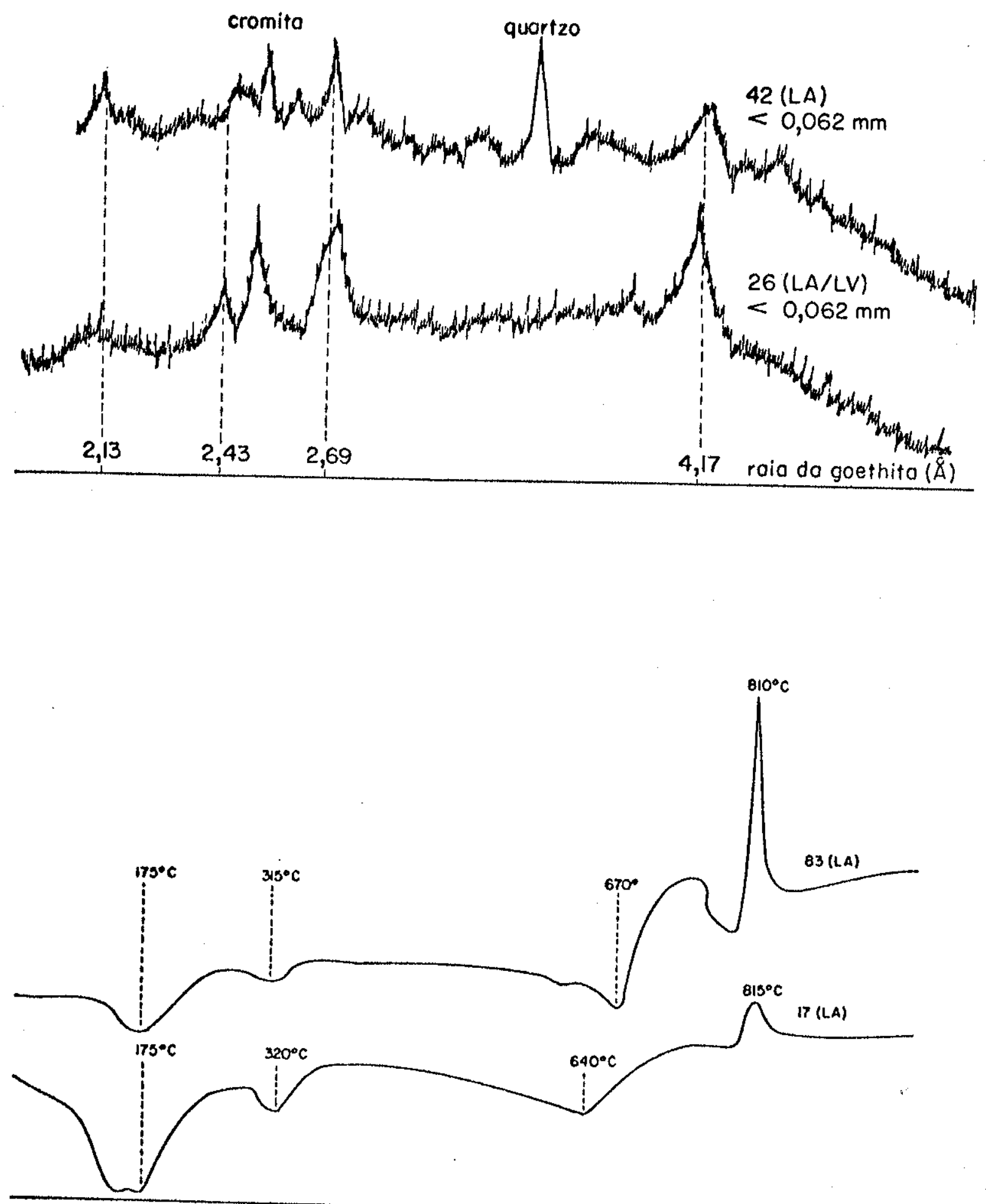

Fig.ll -OAGRAMAS DE ATD E DIFRATOGRAMA DE RAIOS-X PARA A GOETHITA 
teor inferior a $4 \%$ de $A 100 H$ na molëcula de goethita, segun do Thiel 1963, apud Zeissink 1969). O baixo grau de organi zação atômica pode ser devido à incorporação do Ni, AT e Cr pela goethita, o que deforma seu reticulo cristalino (Kuhnel et a. 1974).

Misturadas à laterita amarela, podem ser en contradas placas ou fragmentos de quartzo e calcedōnia, re presentando os veios que cortavam o saprolito grosso e a rocha.

\section{c.5. Laterita vermelha}

E o material que representa o estägio final da alteração. Aï praticamente nada mais resta dos silica tos, sendo um horizonte essencialmente constituído por ōxi dos e hidrōxidos de Fe e por uma pequena quantidade de amorfos. Apenas os minerais micāceos, ligeiramente evoluĩdos, subsistem, apresentando um enriquecimento relativo.

0s grãos de cromita, parcialmente corroidos, recobrem-se de hidröxidos de Fe, constituindo os ȫlitos e pisōlitos. Grãos de quartzo tambëm exercem o papel de nücleos de concreções. Solos pisolitticos recobrindo rochas ultrabäsicas foram descritos por Smith $\xi$ Green 1961 em $\mathrm{Pa}-$ pua, Nova Guinē,e por Jurkovic 1963 na Venezuela.

Na laterita vermelha, a goethita evolui para hematita, mineral de difícil caracterização aos raios $x$. Sua presença, sugerida nos difratogramas, é confirmada pe1 a grande quantidade de Fe neste horizonte, baixa perda ao fogo e quantidade minnima de amorfos (vide "A evolução química"). A anälise tērmica diferencial da LV mostra o desaparecimento do pico endotérmico característico da goethita.

Essa tendēncia de evolução, tendo como ter- 
mo final a hematita, foi constatada tambëm nos produtos de alteração das rochas ultrabäsicas na Nova Caledōnia (Besset 1978), na Africa Ocidental (BTot et a.l. 1976, Leprun 1979) e na Indonēsia (Kuhnel et al. 1978).

c.6. Materiais ricos em Ni: um resumo

A natureza dos materiais que mostram enriquecimento em $\mathrm{Ni} \overline{\mathrm{e}}$, em Santa $\mathrm{F} \overline{\mathrm{e}}$, bastante variada. Podem ser agrupados em tres tipos, quais sejam, saprolito mais ou menos alterado, veios de garnierita cortando a rocha du ra e bolsões ou veios de vermiculita alterada.

Nos materiais que constituem a maior parte do minërio, o $\mathrm{Ni}$ não se encontra como mineral niquelifero individualizado, mas parece associado aos materiais em estado amorfo e à serpentina, nos nïveis menos alterados, ou à goethita, nos niveis mais alterados. Evidencias de ordem química corroboram esta hipōtese e serão discutidas adiante. Cabe acrescentar que as concentrações de $\mathrm{Ni}$ extendem se desde o saprolito grosseiro ate a laterita vermelha, atingindo os mäximos teores no topo do saprolito grosseiro.

Sob o nome genērico "garnierita", são geralmente descritos os materiais de cor verde caracteristica, compostos de silicatos de Mg e Ni hidratados (Faust 1966, Brindley $\xi$ Hang 1973, Hang $\xi$ Brindley 1973, Uyeda et al. 1973). Em Santa Fé, veios verdes, de espessura variāvel de frações de milīmetros a alguns centimetros, cortam a rocha dura e são constituidos por uma mistura de serpentina, quartzo e talco hidratado. Essa mistura tambēm pode ocorrer ocupando as cavidades do boxwork. Uma avaliação semiquantitativa permite constatar que,quanto maior o teor em talco hidratado, maior o teor em $\mathrm{Ni}$, o que indica a associaçăo do $\mathrm{Ni}$ com este mineral. Trata-se de uma sērie isomörfica de filossilicatos trioctaëdricos magnesianos e ni- 
quelïferos, de estrutura 2:1, com espaçamento basal de cer ca de $10 \AA$ e que näo apresentam expansão quando tratados ao etileno-glicol (fig.12). Maksimovic 1966 e Brindley $\xi$ Marksimovic 1974 propöem para os membros extremos desta sērie os nomes kerolita (Mg) e pimelita (Ni), respectivamente. Brindley $\xi$ Hang 1973 sugerem que o maior conteūdo em ägua destes minerais tipo talco corresponda a uma compo sição de talco monohidratado de förmula téörica $\mathrm{Mg}_{3} \mathrm{Si}_{4} \mathrm{O}_{10}$ $(\mathrm{OH})_{2} \cdot \mathrm{H}_{2} \mathrm{O}$. A a ăgua adicional deve ocupar posições interfoliares como o $K$ nas muscovitas, aumentando o espaçamento basal de 9,3 \& para 10 \&. 0 fato de esta água não formar camadas completas deve ser a explicação para a dificuldade desses minerais em apresentar qualquer expansão. Brindley 1978 retomou este assunto e verificou que esta āgua pode ser retirada a temperaturas inferiores a $3000 \mathrm{C}$ e, a partir disso, reformulou suas idēias sobre a forma de inserção desta molēcula no retículo da kerolita. Os detalhes desse estudo deverão ser apresentados por Brindley num prōximo trabalho que se encontra em fase de elaboração.

Uma outra forma de ocorrência de materiais enriquecidos em $\mathrm{Ni}$ são os bolsões de vermiculita finamente dividida. Esse material, de origem hipōgena, relacionada ã serpentinização, funciona como uma armadilha para o Ni,que ë adsorvido a partir de soluçōes percolantes. A forma de inserção do $N i$ no retĩculo do cristal de vermiculita será discutida no capitulo que trata da evolução química.

As formas de concentração de $\mathrm{Ni}$ acima descritas apresentam paralelos em outras jazidas do mundo. Avias 1978, fazendo um resumo da evolução das idēias sobre a gênese e natureza dos minērios de $\mathrm{Ni}$ lateriticos, afirma que è comum que a serpentina hipögena possa servir de arma ditha para o Ni, retendo-o adsorvido na superfície ou em suas fissuras, como foi mostrado por Trescases 1975. E 0 mesmo caso das serpentinas ricas em $\mathrm{Ni}$ de Liberdade (MG), descritas por Esson $\xi$ Santos 1978. Besset $\xi$ Coudray 1978 


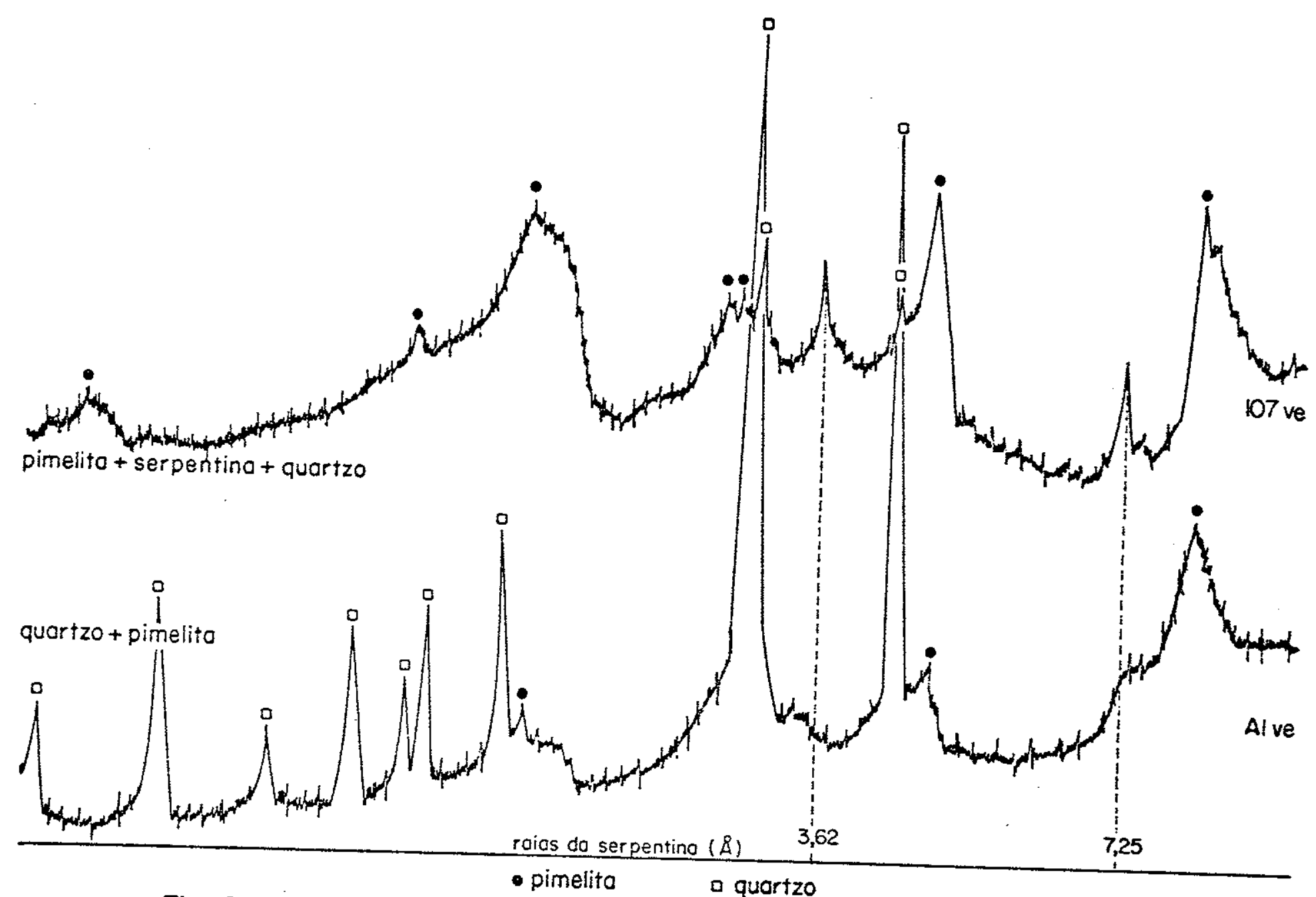

Fig.I2-DIFRATOGRAMAS DE RAIOS -X PARA AMOSTRAS DE GARNIERITA 
chamam a atenção para o fato de que na Nova Caledōnia uma parte do $\mathrm{Ni}$ fica associada aos amorfos silico-ferruginosos.

Um dos autores que mais estudaram o problema da localização do $\mathrm{Ni}$ na zona limonĩtica dos perfis de alteração foi Schelimann 1976 e 1978. Nestes trabalhos,ele demonstra que $90 \%$ do $\mathrm{Ni}$ contido nos horizontes ferruginosos dos muitos perfis estudados estä ocupando posições no retīculo da goethita. Serve de base a esta afirmação,entre outros argumentos, o fato de que, submetida a goethita niquelifera à lixiviação com äcido fraco, ocorre dissolução conjunta do $\mathrm{Ni}$ e do Fe. Outra linha de suporte a essa hipötese diz respeito à possibilidade de sīntese, no laboratörio, de goethi ta niquelifera.

Quanto ă composiçăo das garnieritas são muitos os exemplos de minerais da sërie kerolita-pimelita: Nova Caledōnia (Trescases 1975), Liberdade (Esson $\xi$ Santos 1978), Morro do Nĩquel (Trescases $\xi 01$ iveira 1978), Iugosla via (Marksimovic 1966), Oregon (Brindley $\xi$ Hang 1973) etc. Souza et al. 1973, num trabalho sobre caracterização minera lögica de argilas niqueliferas brasileiras, não mencionaram a presença destes minerais em Niquelândia e Jacupiranga.

A vermiculita niquelifera de Santa $F \bar{e}$ parece assemelhar-se ä descrita por Ross $\xi$ Earl 1926 e Ross et az. 1928 na Carolina do Norte. Neste caso, a vermiculita, ao al terar-se, incorpora o $\mathrm{Ni}$ proveniente da dissolução da olivi na. No segundo trabalho citado, os autores mencionam a possibilidade experimental de obtenção de vermiculita niquelĩfera, fazendo mergulhar vermiculita numa solução contendo
$\mathrm{Ni}$.

B. A Alteraçăo do Peridotito e do Piroxenito

0 perfil de alteração sobre peridotito e pi- 
roxenito compõe-se basicamente dos mesmos fäcies que ocorrem sobre dunito, sendo que, no entanto, os produtos de alteração assumem cores mais claras e são mais argilosos, ã medida que as rochas apresentam maior conteüdo em piroxẽnio. Assim, o peridotito alterado $\bar{e}$ verde amarelado e possui maior porcentagem de finos que o dunito serpentinizado alte rado. O piroxenito decompöe-se numa massa verde clara bastante argilosa. A distribuição dos minerais pelos diferentes fäcies de alteração sobre piroxenito consta da tabela 6.

\section{a. O perfil sobre peridotito}

0 perfil estudado apresenta $3 \mathrm{~m}$ de profundida de, e não atinge a rocha dura. 0 fäcies menos alterado encontrado no fundo deste poço è o saprolito grosseiro, composto por piroxēnio, olivina e serpentina em quantidades su bordinadas, mineral micāceo, esmectitas e opacos, sendo estes mais abundantes que nos dunitos alterados. 0 piroxënio apresenta-se, neste horizonte, ainda bem fresco e brithante, embora, ao longo de suas fraturas e em suas bordas, jā come cem a aparecer sinais de alteração, representados por um ma terial argiloso verde claro, identificado como um filossili cato 2:1 da familia das esmectitas. A olivina ē rara e aparece como restos de cristais bastante corrojdos; sua existência ē também atestada por fantasmas que guardam sua anti ga forma, preenchidos por material ferruginoso. Formando um reticulado caracterïstico, geralmente vazio no centro, ocor rem restos de serpentina. 0 mineral micáceo apresenta, tal como nos dunitos, caracteristicas intermediärias entre vermiculita e clorita. Os opacos, em sua maioria xenomorfos, compõem-se por magnetita, ilmenita e alguma cromita. A esmec tita compete com o piroxênio em abundância neste horizonte, inserindo-se entre os grãos dos cristais acima descritos.os carbonatos, presentes no peridotito fresco, não existem no saprolito grosso. 
TABELA 6

AVALIAÇAO SEMI-QUNNTITATIVA DOS MINERAIS PRESENTES NOS FACIES DE AITERACAO SOBRE PIROXENITO

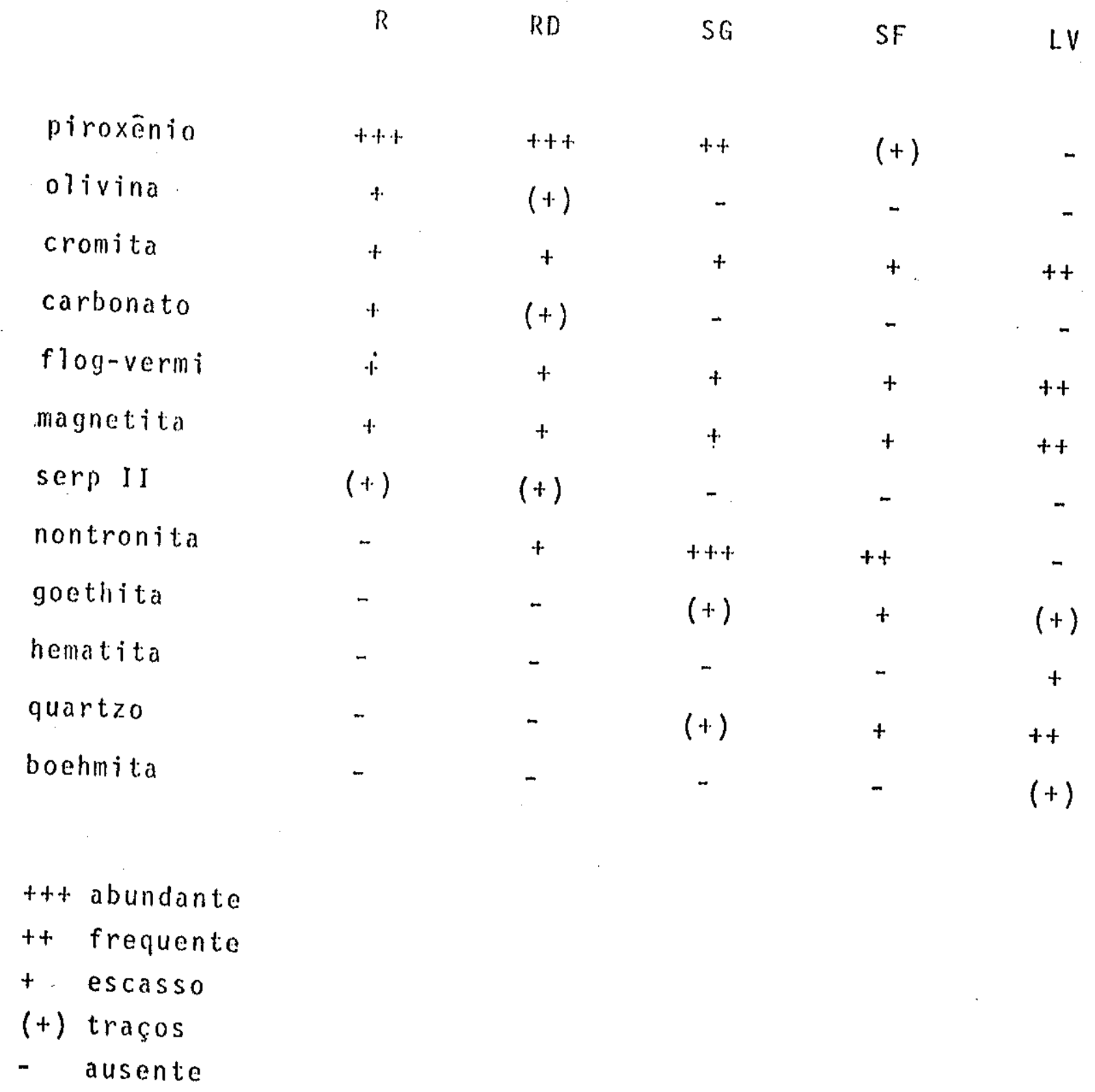


Sobre o saprolito grosso, numa transiçäo con tinua, segue-se $1,5 \mathrm{~m}$ de material saprolitico fino de cor $a$ marela, mais ou menos avermelhada. Nele a olivina e a serpentina estão totalmente ausentes, restando um pouco de piroxênio, mineral micäceo e opacos. A esmectita tambēm parece diminuir em quantidade, dando lugar à goethita. o quartzo aparece em proporção reduzida.

No topo do perfi1, uma camada de mais ou menos um metro de laterita vermelha com sejxos de canga repre senta o material final da alteração. Neste horizonte, os ūnicos minerais hipögenos que subsistem são os opacos, mergulhados numa matriz composta por ōxidos e hidrōxidos de Fe mais ou menos bem cristalizados.

\section{b. O perfil sobre piroxenito}

0 perfil sobre piroxenito, apesar da profundidade de quase $10 \mathrm{~m}$, tambēm não alcança a rocha dura. Os pri meiros $4 \mathrm{~m}$ a partir do fundo são constituĩdos por um material saprolitico de cor verde clara, bastante argiloso e que conserva a estrutura da rocha original. Seu conteūdo mi neralögico consiste em restos de piroxēnio,mineral micáceo, alguns opacos e muita esmectita. Aqui as "micas" são produtos intermediārios da sërie trioctaëdrica flogopita- hidrobiotita-vermiculita, apresentando características quimicas e estruturais entre os dois extremos. A esmectita pertence à sērie dioctaēdrica (nontronita), e, assim como as "micas", foram estudadas do ponto de vista quĩmico e por microscopia eletrônica por 01 iveira $\xi$ Melfi 1978.

Com a alteração, em direção ao topo do perfil, esse material verde vaj dando lugar a um saprolito ama relado que constitui um horizonte de aproximadamente $2 \mathrm{~m}$ de espessura, de estrutura conservada. Neste horizonte, quase todo o piroxēnio ja desapareceu e a nontronita vai diminuin do, dando lugar ao aparecimento da goethita. As micas perma 
necem intactas e aparecem os primeiros sinais de quartzo.

Uma camada de $4 m$ de laterita vermelha, par cialmente remanejada, completa o perfil de alteração. E formada por uma matriz ferruginosa composta por goethita, hematita e algum Fe amorfo, onde estão imersos os cristais de quartzo, provavelmente de origem coluvionar, e "micas " herdadas de rocha fresca. Estas, ligeiramente evoluidas em direção ao polo vermiculita, apresentam, quando examinadas ao microscōpio eletrônico, lamelas encurvadas e preenchidas de maneira incipiente por um mineral de estrutura tip ca de esmectita (01iveira $\xi$ Melfi 1978). Os diagramas de ATD referentes aos värios estägios de alteração do piroxenito estão representados na fig 13. As curvas referentes às amostras 93 e 97 não são tĩpicas de nontronita, embora apresentem alguns de seus picos caracteristicos (1800C e 8550 C). As amostras de LV, 100 e 102 , mostram picos da goe thita ( $\approx 3200 \mathrm{C})$ e um par de picos a 565 e $9200 \mathrm{C}$ que podem corresponder à formação de um ōxido de AT hidratado, a boehmita (Mackenzie 1957 ).

C. Distribuição Espacial dos Fäcies de Alteração

A estrutura, composição quïmica e mineralögica dos fäcies de alteração em cada sitio topogräfico são condicionadas, entre outros fatores, pela histöria morfoclimätica, e sō podem ser inteiramente compreendidas à 1 uz do conhecimento da gēnese do relevo. Antes de partir para uma interpretação da distribuição espacial dos fäcies de alteração, tratar-se-ā, neste item, de descrever a natureza dos materiais em cada segmento da paisagem.

Nas parte mais altas do relevo, representadas pelos topos da Serra do Tira-pressa e dos morrotes esparsos, afloram dois tipos de materiais:

- dunito quase fresco, recoberto por uma ca 


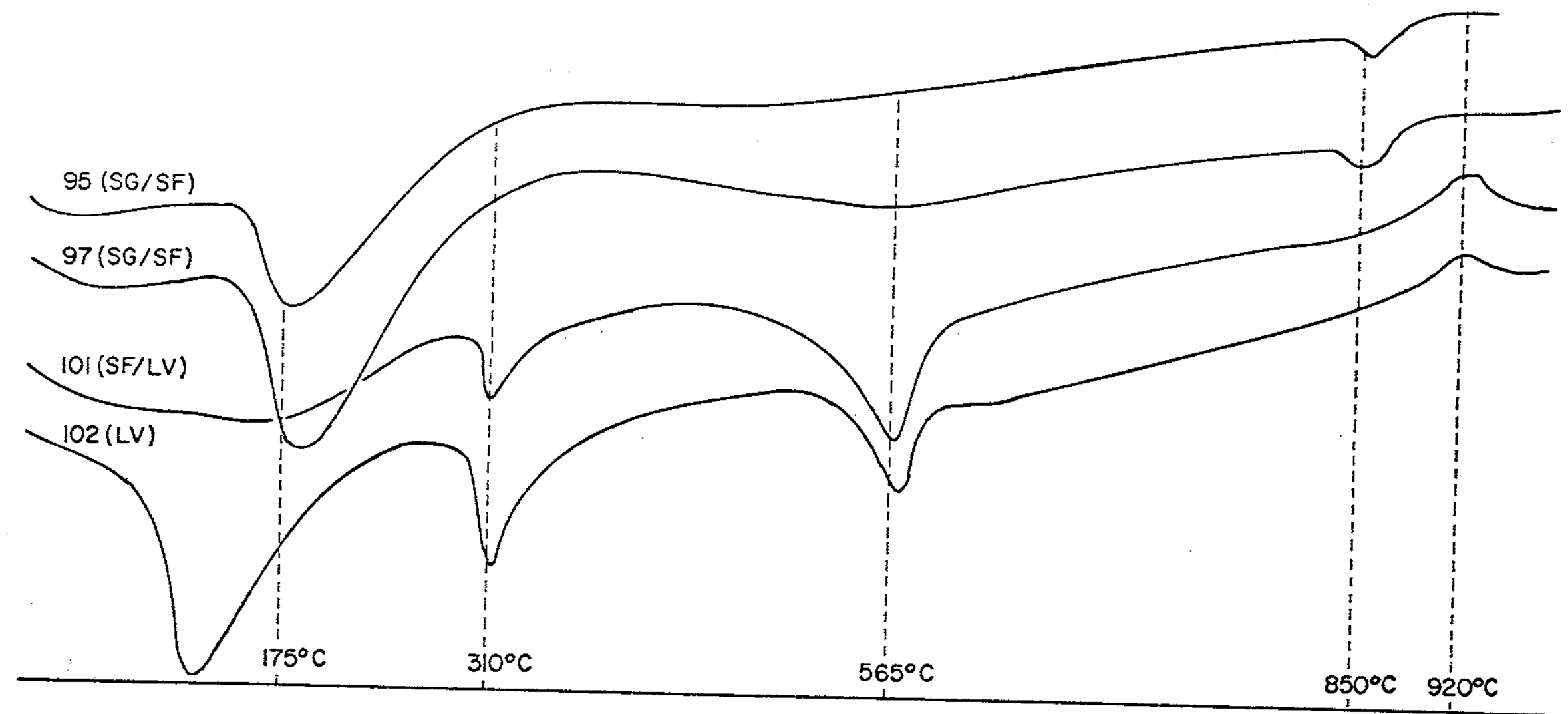

Fig. 13 - DIAGRAMAS DE ATD PARA AMOSTRAS DO PERFIL SOBRE PIROXENITO 
mada de menos de meio metro de espessura de laterita vermeIha;

- crostas silicificadas que podem atingir atē $15 \mathrm{~m}$ de espessura, constituidas de silijca de grau de cris talinidade variado (quartzo, calcedónia e opala), mais ou menos impregnado por Fe. Muitas vezes ocorrem estruturadas em boxwork, com vestigios de rocha saprolitizada ou laterizada no interior de suas celas; outras vezes, formam veios ou placas dispostas segundo a estrutura da rocha dunitica 0 riginal, esta parcial ou totalmente desaparecida. As silici ficações ocorrem em larga escala nos topos do Tira-Pressa, ao sul, e no alto do morro do Caiçara, no limite leste do maciço, formando uma placa de proteção que protege estes cu mes da erosão. Nos outros morrotes predomina a rocha quase fresca, podendo ocorrer silicificação incipiente.

Nas encostas e nos sopēs dos morros, começa a aparecer um perfil mais completo, com as passagens RD-SGLA-LV mais bem caracterizadas. A camada de laterita vermeTha $\vec{e}$ continua e apresenta espessura crescente em direção às partes mais baixas, enquanto que os niveis de laterita a marela, apresentando, de modo geral, este mesmo comportamen to, podem desaparecer em certos trechos.

As baixadas, que ocupam a maior parte da ärea do maciço, são caracterizadas por apresentarem um perfil de alteração mais desenvolvido, onde a laterita vermeTha e a laterita amarela chegam a atingir 5 e $3 \mathrm{~m}$, respectivamente. Sotoposto a estas camadas, segue-se um nỉvel de sa prolito grosso de 2 a $3 m$ que passa gradualmente à rocha dura. Feição característica das baixadas ē a existēncia generalizada de concreções ferruginosas ooliticas e pisoliticas, localmente soldadas, formando crostas. Estas concreções, ma terial formador da laterita vermelha em muitos trechos das baixadas, foram estudadas por Barbour 1976. Este autor descreve os oôlitos como de forma arredondada, de tamanho pre- 
dominante entre 32 e 115 mesh, com nücleos de magnetita,cro mita, quartzo ou fragmentos de outras concreções, envolvidos por goethita ou por hematita. Os pisölitos, de dimensões maiores $(1-10 \mathrm{~mm})$, têm constituição mineralögica semeThante, porēm com um grau maior de hidratação. Nas zonas mais baixas, de convergēncia de āguas superficiais e de nîvel freatico raso, formaram-se crostas continuas de espessura decimētrica, compostas pelos oölitos e pisōlitos acima descritos, cimentado por material ferruginoso. Como material rolado ou coluvionar, ocorrem nas baixadas fragmentos das crostas silicificadas com cörtex ferruginoso, erodidas
das partes altas do relevo. As figuras $14,15,16,17$ e 18 mostram a distri
buição dos fäcies de alteraçäo ao longo de 5 topossequën
cias distribuĩdas pelo macico. cias distribuidas pelo maciço.

D. As Filiaçöes Mineralögicas

A figura 19 resume a hipōtese explicativa a respeito da gênese e do destino de cada mineral.

A rocha original, de natureza dunitica, sofrendo retromorfose na ēpoca da mise-en-place, transformouse num dunito serpentinizado, cuja paragënese jä foi discutida no capitulo I. São, portanto, minerais constituintes da rocha fresca, matëria-prima para a alteraçäo supërgena, a olivina, a serpentina do reticulo (I), a serpentina micro-. cristalina que ocupa o centro do reticulo (II), mineral micäceo tipo vermiculita-clorita, carbonatos e brucita, ale dos opacos magnetita e cromita.

Logo nos primeiros estägios da alteração meteörica, a olivina pode sofrer hidrölise, deixando em seu lugar vazios ou um resíduo da dissolução de cor castanha, sem caracteristicas opticas definidas, interpretados como 


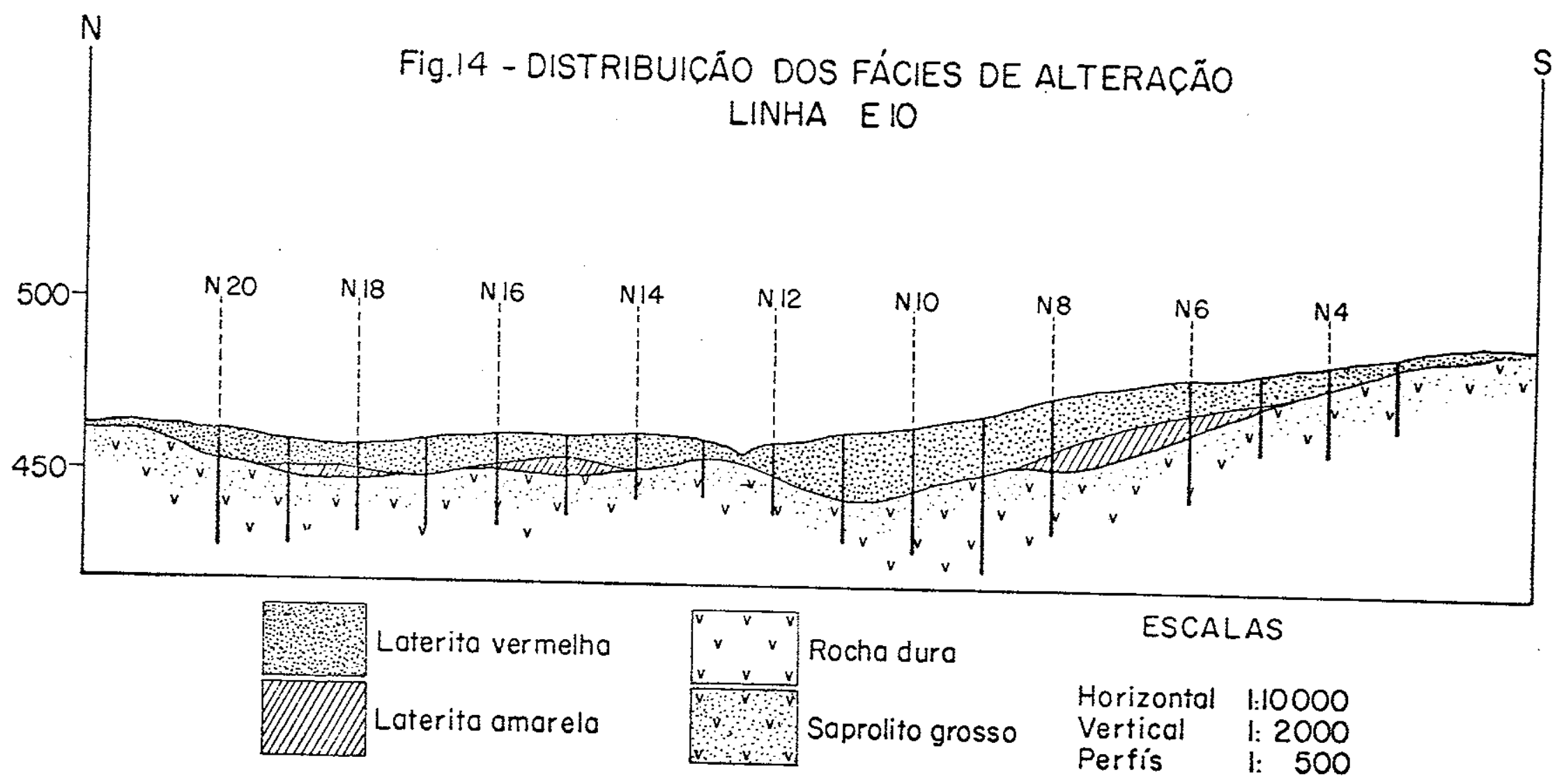




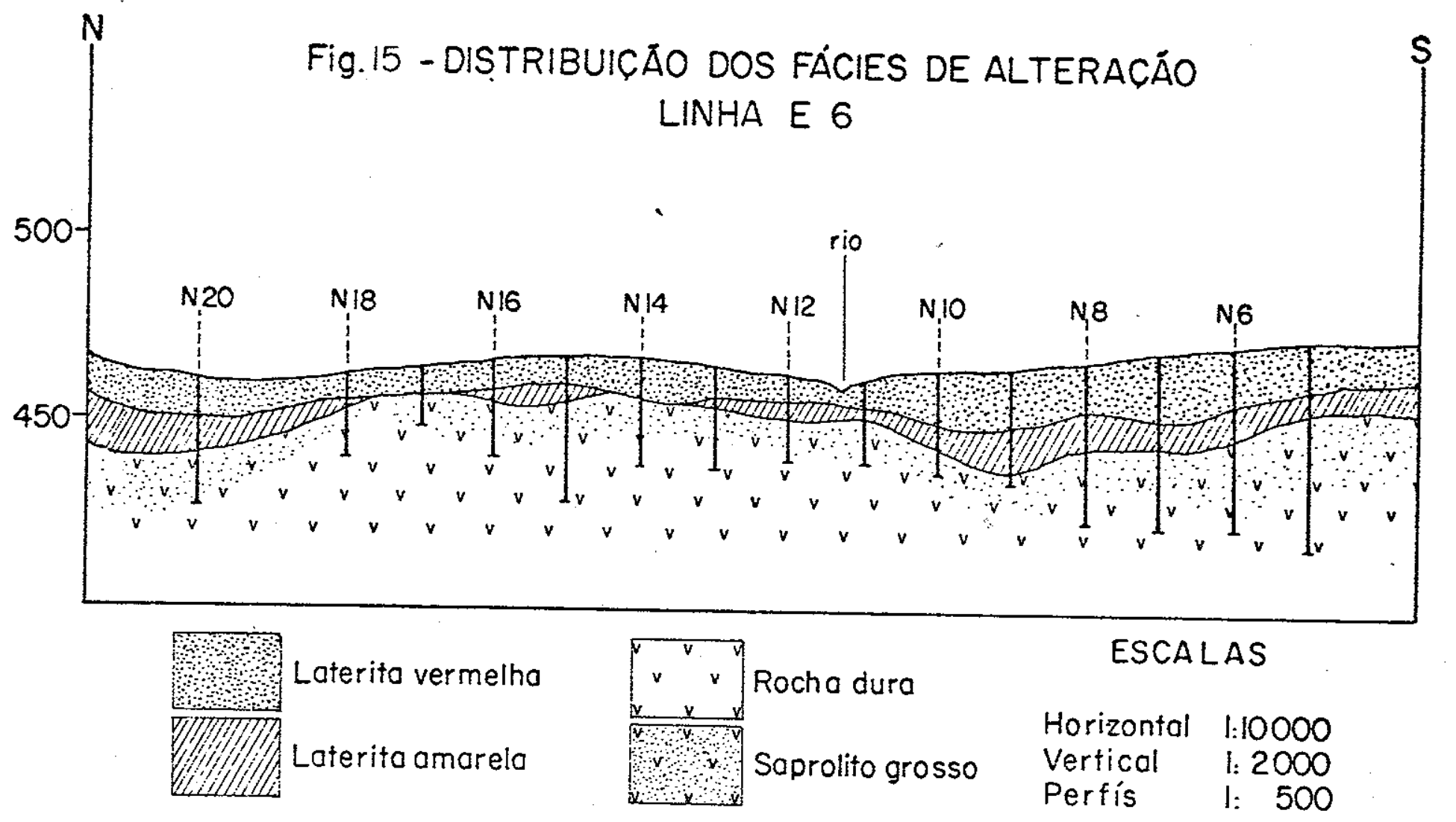




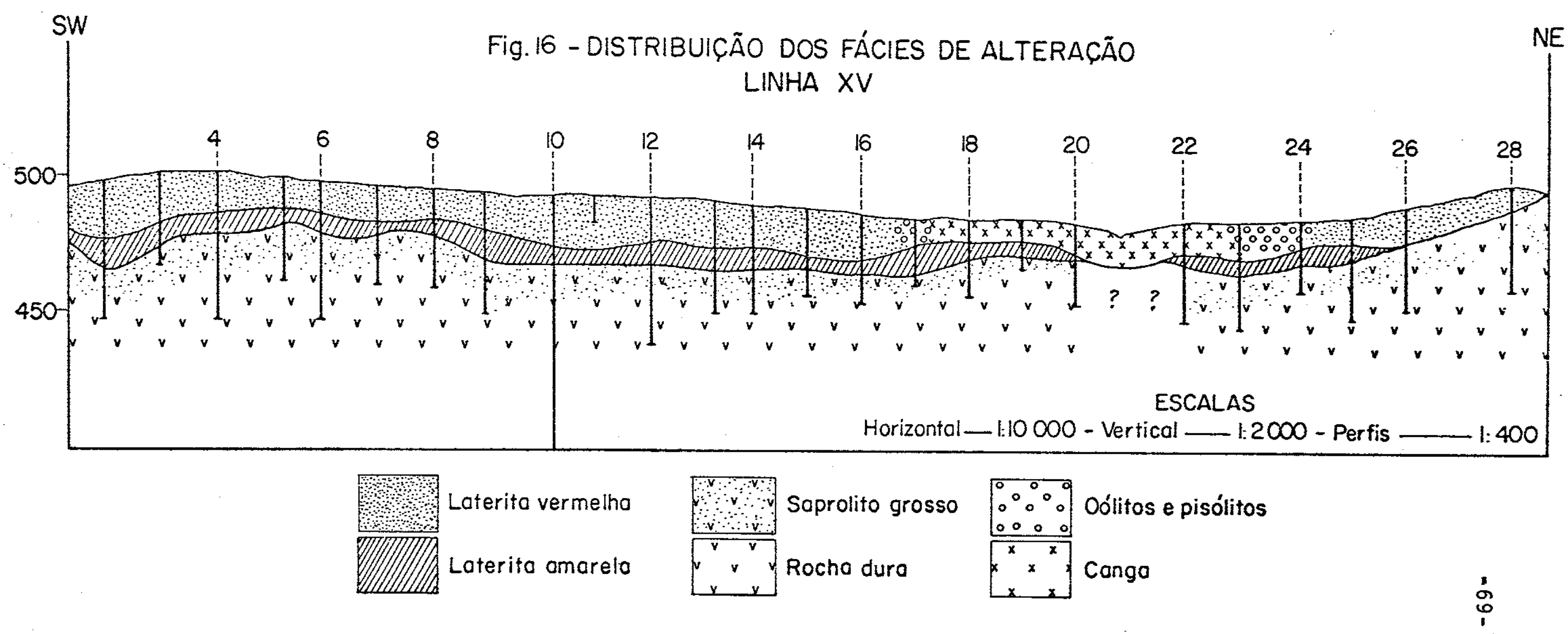




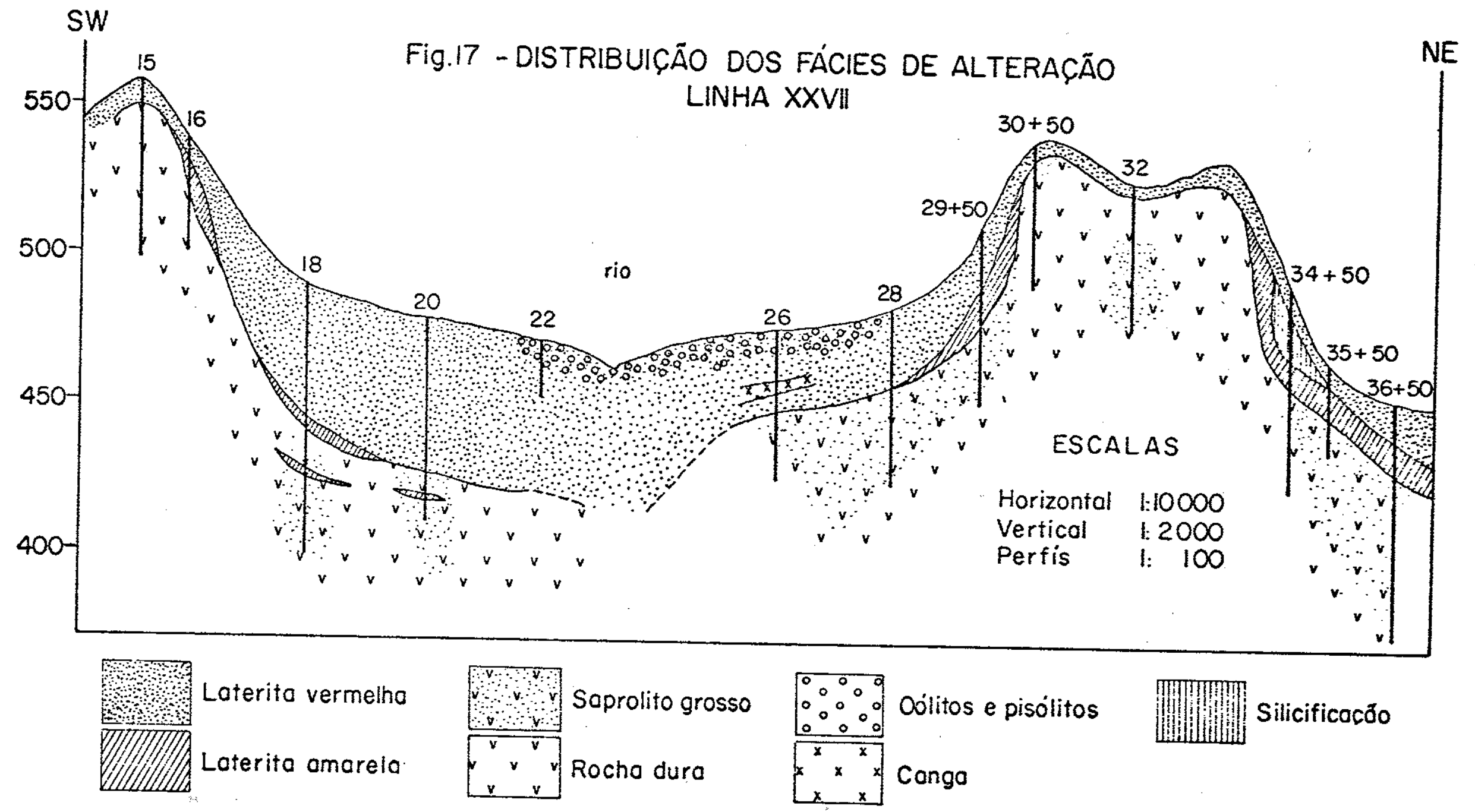




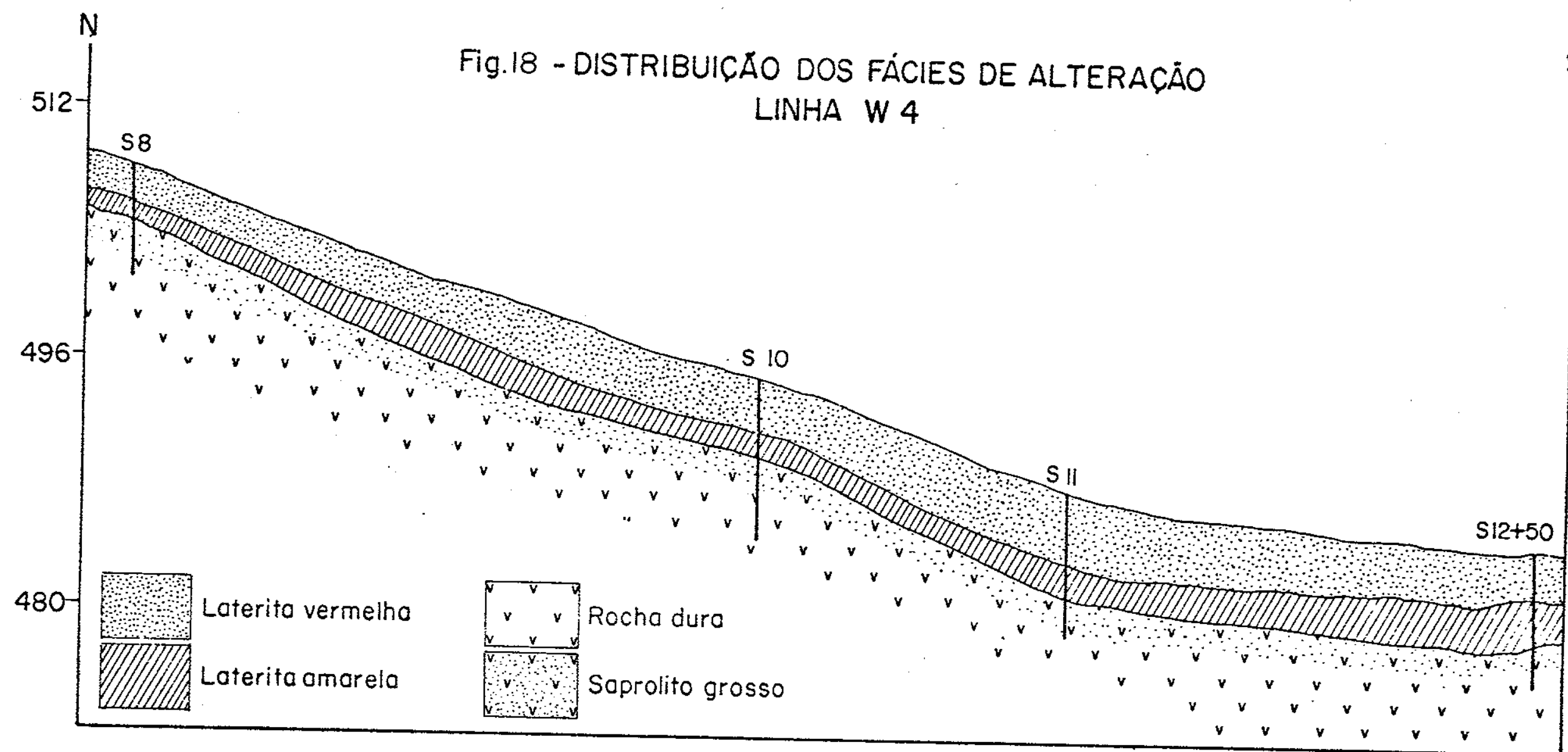

Horizontal_t: 2000 - Vertical_LCALAS 
FIGURA 19

FILIACOES MIMERALOGICAS

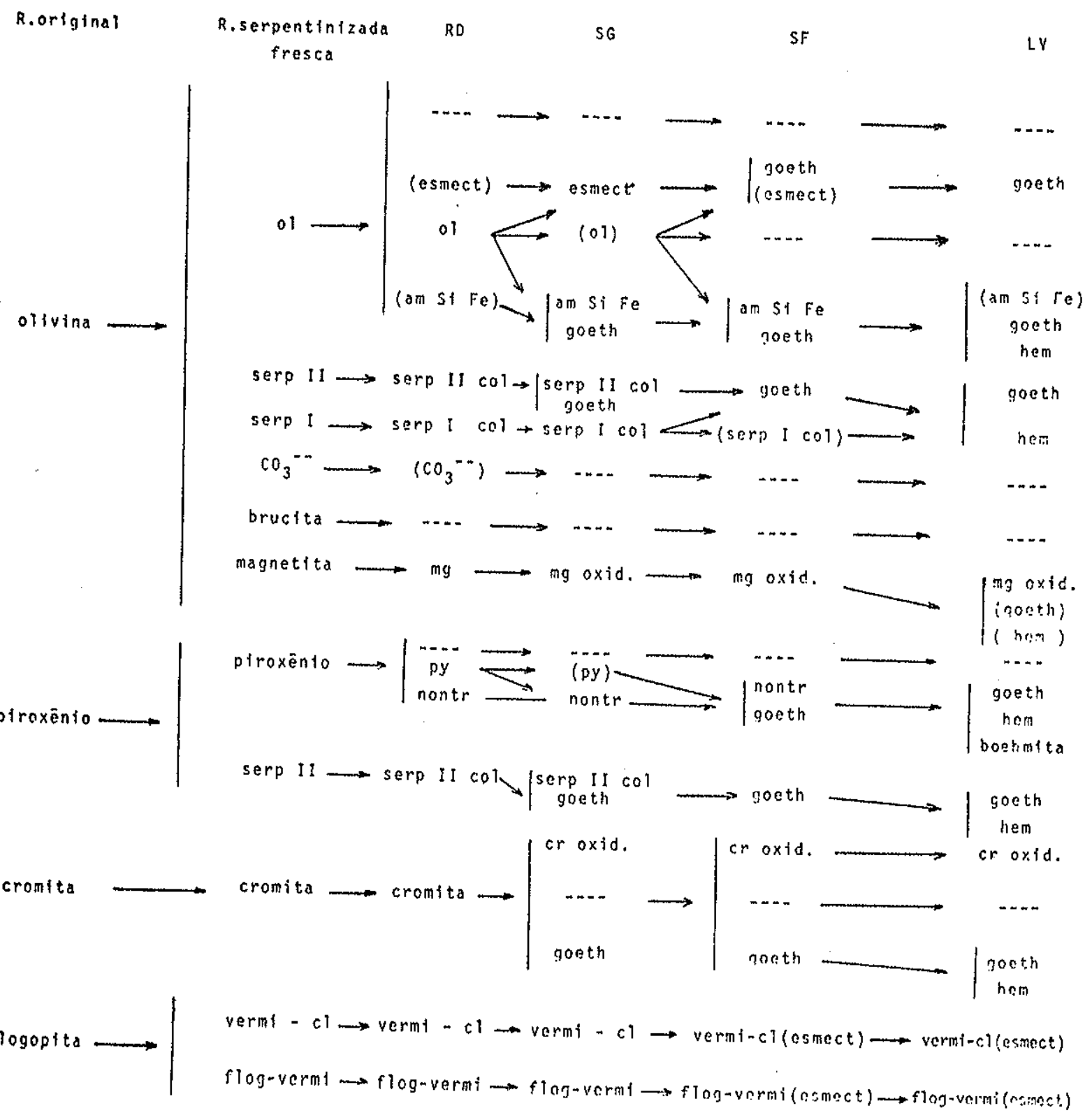


morfos de Si e Fe (Trescases 1975, Melfi 1974). Provavelmen te associado a esse material, existe um outro produto da evolução da olivina, a esmectita, cuja natureza não foi pos sĩvel precisar. Este filossilicato tem vida curta, alterando-se logo em seguida para goethita. Os amorfos de $\mathrm{Si}$ e $\mathrm{Fe}$ sofrem dessilicificação e o resīduo cristaliza-se em goeth ta. A tendéncia final da evolução è em direção ao termo fer ruginoso menos hidratado, a hematita.

A serpentina resiste mais à alteração que a olivina, sendo que a variedade menos bem cristalizada (serp. II) altera-se primeiro, transformando-se numa massa amorfa de cor castanho avermelhada. O Fe liberado pela hidrölise da olivina colore a serpentina I desde cedo de amarelo e ela permanece mais ou menos inalterada, mantendo o arcabouço da rocha até estägios bem evolǘdos, representados pela laterita amarela. A anāilise dos diagramas de ATD do material cada vez mais alterado mostra que o desaparecimento da serpentina da-se concomitantemente com o aparecimento da goethita, indicando que este üitimo mineral seja seu produto de evolução (fig 20). Ao microscōpio,observam-se as fibras de serpentina descolando-se uma das outras e sendo invadidas por material ferruginoso. A tendência final $\vec{e}$, assim como para a olivina, em direção à hematita.

Os carbonatos e a brucita sofrem dissolução logo nas primeiras fases do processo de alteração meteórica, sendo que o hidrōxido $\bar{e}$ mais prontamente levado em solução que os carbonatos.

Dentre os opacos, $\overline{\mathrm{e}}$ a magnetita que mostra os primeiros sinais de oxidação, assumindo, desde cedo, tons avermelhados, enquanto a cromita continua preta. Devido ao caräter idiomōrfico dos grãos de cromita, ē facil identificar sinais de corrosão. Isto acontece logo no inicio da a iteração, e o material dissolvido acaba cristalizando-se em goethita. A literatura refere alteração de cromita em maghe 


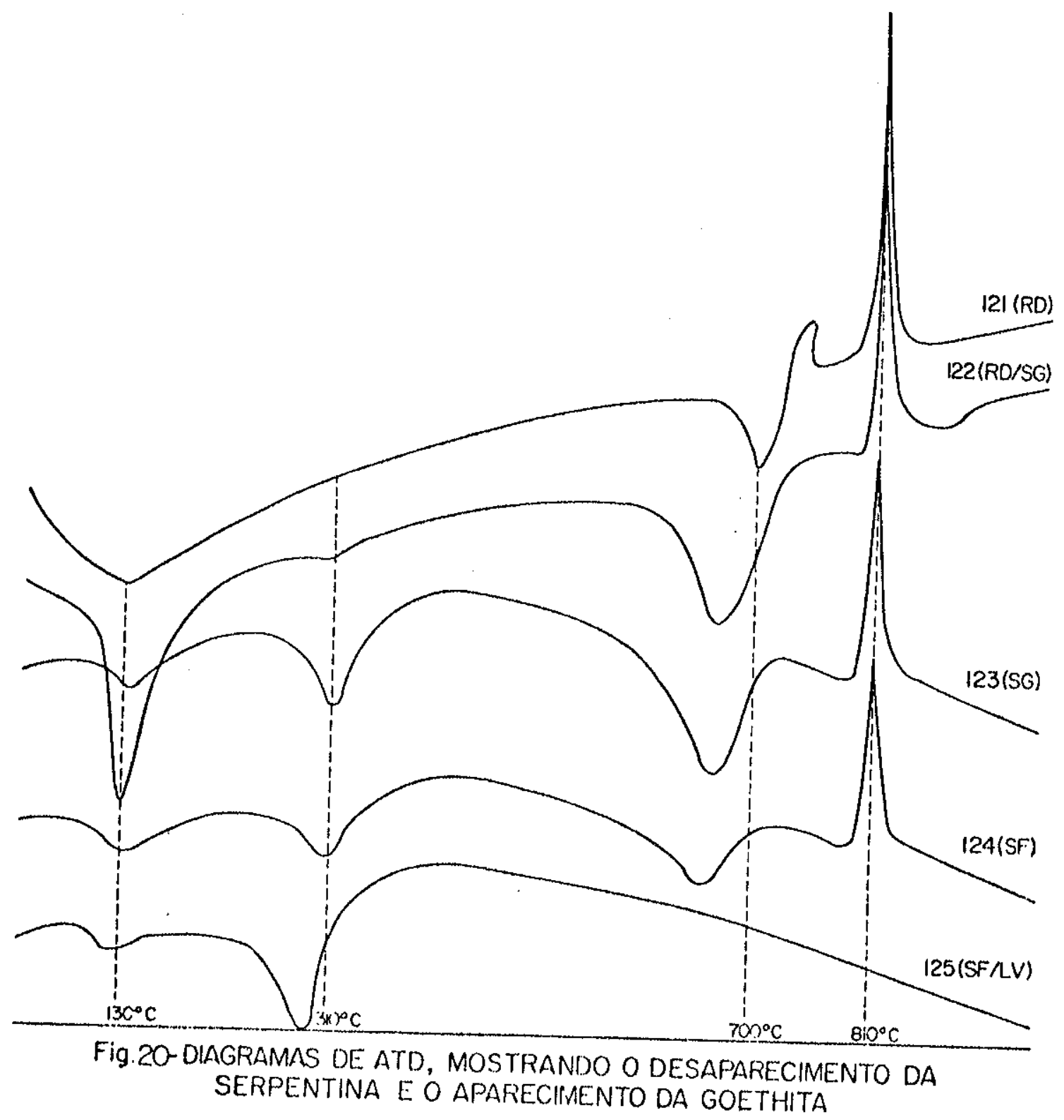


mita (Miller 1953 e Tex 1955) o que não foi constatado aqui, devido talvez à dificuldade de identificaçăo deste mineral aos raios $x$. Os grãos de cromita, corroïdos ou não, terminam tambēm por sofrer oxidação, revestindo-se de uma camada avermelhada de goethita e hematita, o que dificulta o prosseguimento do processo. Assim, tanto a magnetita como a cro mita resistem, atē certo ponto, à alteraçäo, e são encontrá das no solo como minerais residuais; às vezes formam os nücleos das concreçöes ooliticas e pisoliticas.

0 mineral micäceo do tipo vermiculita-clorita, alëm de aparecer disperso por toda a rocha, apresenta um modo de ocorrência particular, qual seja, em intima asso ciação com a cromita. Neste caso, parece resultar de uma reação de borda cromita-serpentina, levando a um filossilicato, possivelmente enriquecido em $\mathrm{Cr}$. Tanto neste caso como no outro, a vermiculita-clorita comporta-se como um mine ral resistente à alteraçäo, concentrando-se residualmente nos materiais mais evoluidos e sofrendo ligeira transformação em esmectita. Este filossilicato 2:1 insere-se por entre as palhetas da vermiculita-clorita, näo destruindo sua estrutura, o que sugere sua gēnese por transformação. A ver miculita-clorita pode ser encontrada como nūcleo das concre ções ferruginosas.

Preenchendo as fissuras submilimëtricas a mi limetricas da rocha dura, ocorrem dois minerais formados por neogēnese a partir de soluções: os filossilicatos da se rie pimelita-kerolita e o quartzo. A kerolita forma-se na base do perfil a partir de soluções ricas em Si e $\mathrm{Mg}$, prove nientes da hidrölise, da olivina e pode ser muito rica em $\mathrm{Ni}$, sendo o principal constituinte da garnierita. Como este mineral se forma por precipitaçäo a partir de soluçöes descendentes, e como o $\mathrm{Mg} \bar{e}$ mais solüvel que o $\mathrm{Ni}$, hä uma tendēncia preferencial de formaçäo de kerolita (Mg) nos horizontes mais inferiores e pimelita (Ni) nos niveis superiores da rocha pouco alterada. Um zoneamento deste tipo foi 
descrito por Maksimovic 1966, na Iugoslävia. No decorrer do processo de alteração, a kerolita-pimelita acaba por dissol ver-se. 0 quartzo, originado de precipitaçäo, forma-se tambëm na base do perfil, um pouco mais tarde, quando da dessi licificação dos amorfos de Si e Fe.Instala-se nas diäclases do serpentinito e permanece residualmente at $\vec{e}$ os niveis mais alterados. Quando o processo de silicificação atua intensamente, forma-se o que se descreveu como boxwork, ou se ja, um reticulado de quartzo e calcedónia, rëplica da estrú tura original do serpentinito, cujos poros säo preenchidos por materiat lateritico. os demais minerais que ocorrem nos veios ou fissuras, quais sejam, a serpentina, a brucita e os carbonatos, säo interpretados como residuais, de origem hipögena.

A evoluçăo dos veios estā resumida na figura 21. A hipotese explicativa das filiaçöes mineralögicas nos veios $\vec{e}$ corroborada pelas seguintes evidências:

- carbonatos e brucita sö säo encontrados na rocha fresca ou quase fresca (são hipögenos);

- näo existe quartzo, nem "talco" $10 \AA$ na rocha fresca (säo supërgenos);

- existem veios de carbonatos, brucita e serpentina III na rocha fresca (a hipotese da serpentina dos veios ser supërgena $\overline{\mathrm{e}}$ uma hipötese supërflua);

- hā uma correlaçäo negativa entre a quantida de de kerolita e carbonatos nos vejos (á medida que a rocha se altera, o carbonato se dissolve e forma-se a kerolita);

- năo existe a associaçäo carbonatos-quartzo (o quartzo $\vec{e}$ formado tardiamente).

Nos piroxenitos, a alteração supērgena ten- 
FIGURA 21

EVOLUŞAO DOS VEIOS

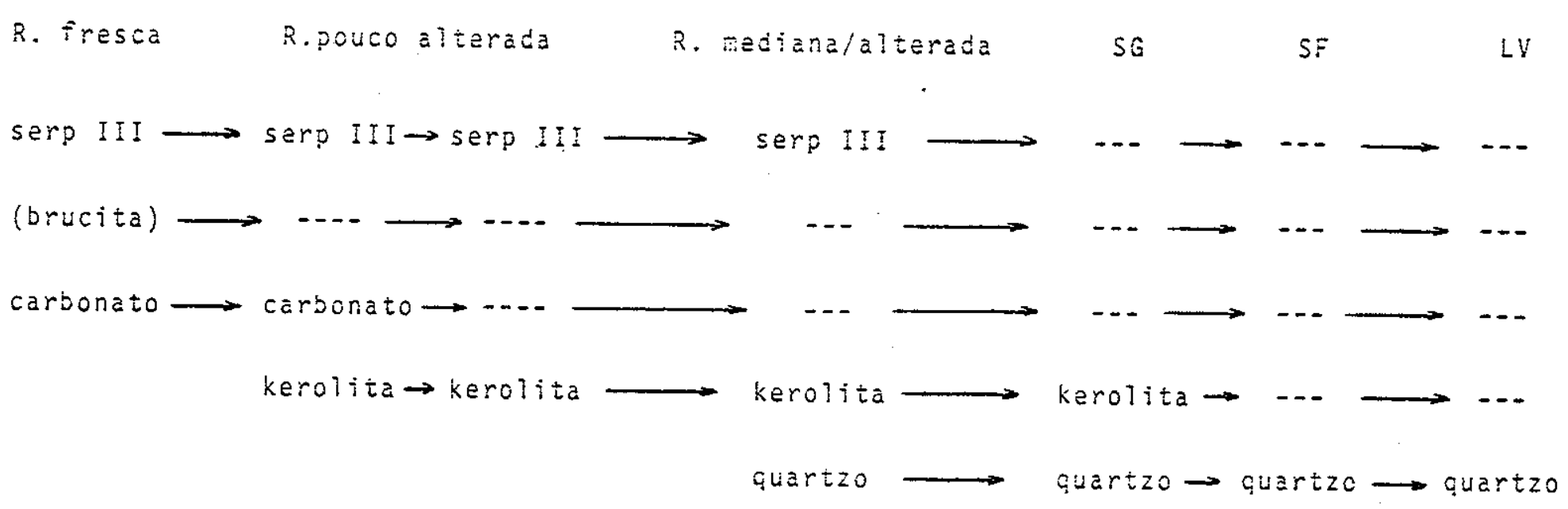


de, num primeiro estăgio, à formação de esmectita rica em. Fe, por nęogênese a partir do piroxênio. Esse mineral acaba evoluindo em direção a materiais ferruginosos (goethita e hematita) e aluminosos (boehmita). A serpentina presente nos piroxenitos segue o mesmo destino que no serpentinito.o mineral micäceo da sërie flogopita-vermiculita comporta- se como residual, evoluindo ligeiramente, por transformação,pa ra esmectita (01iveira $\xi$ Melfi 1978).

\section{A Evoluçăo Quimica}

Neste item serão analisados e interpretados os dados químicos, expressos seja como porcentagens ponderais, seja como porcentagens volumëtricas. o primeiro tipo de apresentação ē o convencional num laboratōrio quïmico e, no estudo da alteraçăo, esses dados podem ser usados para a avaliação da evolução de cada elemento quĩmico durante o processo, bem como de suas evoluções comparadas, atravës dos cālculos das taxas de concentração. A anälise dos coefi cientes de correlaçäo entre pares de elementos revela as se melhanças e divergencias de comportamento. 0s dados volume-tricos, obtidos atraves dos dados ponderais e das medidas de densidade aparente, exprimem quantidades absolutas por unidade de volume. Sua interpretação informa a respeito das perdas e ganhos reais de uma amostra com relação a outra, a partir do que se pode estabelecer a mobilidade absoluta de cada elemento, tanto vertical como lateralmente. 0 produto final da interpretação dos dados volumëtricos $\bar{e} \quad 0$ balanço geoquímico ao nîvel da paisagem.

\section{A. Dados Ponderais}

os dados quimicos ponderais analisados neste trabalho provëm de 2 fontes:

- dados fornecidos pela Montita Mineradora 
Ltda., referentes a 286 amostras, dispostas em perfis sobre. as topossequēncias XV e E6, analisadas para 8 elementos ( $\mathrm{Mg}$, $\mathrm{Fe}, \mathrm{Cr}, \mathrm{Co}, \mathrm{Cu}, \mathrm{Si}, \mathrm{Al}, \mathrm{Ni}$ );

- dados obtidos em amostras coletadas durante duas campanhas de campo, somando mais de uma centena de dunitos serpentinizados e seus produtos de alteraçäo e cerca de 50 amostras de peridotito e piroxenitos alterados, as sociações minerais em veios e crostas ferruginosas ou silicificadas.

A respeito da primeira fonte de dados existem indeterminaçöes de diversas naturezas, a começar pela tëcnica de coleta de amostra. Por ter sido efetuada visando o aproveitamento econōmico da jazida, a amostagem não levou em conta a heterogeneidade do material, resultando que a maior parte das amostras corresponde a um setor de $1 \mathrm{~m}$ do perfil e algumas representam ate $5 \mathrm{~m}$. São, na maior parte das vezes, constituĩdas de misturas de diferentes fācies de alteração. A descrição que se tem delas, quando foi possível obtê-la, e sumäria e insuficiente para fins de caracterizaçäo mineralögica. Com relaçăo aos mëtodos analīticos, a penas se sabe que os teores foram dosados por absorção atõmica, mas näo foi possĩvel obter informaçōes quanto à precisão e exatidäo dos resultados. Como agravante desta situa ção de falta de controle de qualidade dos dados analiticos, hä o fato de näo ter sido dosada a perda ao fogo,que, nestas rochas, atinge valores que podem ultrapassar $10 \%$. Isto impede a verificaçăo da soma a 100\%, critērio imprescindī vel na avaliaçäo da qualidade de uma anälise. No entanto, pesar de todos estes inconvenientes, o grande nümero de anälises disponiveis $\vec{e}$ adequado a um tratamento estatistico, que permitira evidenciar os traços gerais do comportamento dos elementos químicos durante o processo de alteração.

Os dados provenientes da segunda fonte, ao conträrio, correspondem a amostras coletadas cuidadosamente, 
representando fäcies de alteração individualizados; foram descritas minuciosamente do ponto de vista macro e microsco pico e contam com anălise mineralögica detalhada. No caso de conservarem a estrutura original da rocha, a densidade aparente foi determinada. Os mëtodos de anälise química a que foram submetidas (descritos no Apêndice II) foram rigo rosamente testados e mostraram-se adequados. Efetuaram- se anälises sobre amostra total, frações granulomëtricas, amor fos extraidos e sobre frações mineralogicas selecionadas. Fo ram dosados $\mathrm{H}_{2} \mathrm{O}^{+}, \mathrm{SiO}_{2}, \mathrm{Fe}_{2} \mathrm{O}_{3}, \mathrm{MgO} \mathrm{Al}_{2} \mathrm{O}_{3}, \mathrm{Cr}_{2} \mathrm{O}_{3}, \mathrm{CoO}$, CuO, $\mathrm{NiO}$ e, em alguns casos, $\mathrm{MnO}_{2}$ e CaO. O método analitico utilizado permitiu separar a sîlica do quartzo da sílica amorfa e constituinte dos silicatos.

Diante desse quadro de heterogeneidade de da dos, impunha-se a utilizaçäo de um critërio objetivo que permitisse dividir o conjunto de 284 amostras fornecidas pe 1 a Montita Mineradora Ltda. em grupos que correspondessem, aproximadamente aos fäcies de alteraçäo, caracterizados macroscopicamente para as 150 amostras coletadas. Esse criterio deveria basear-se essencialmente em dados quimicos e exprimir o estädio de alteração do material.

Dado que a densidade aparente da amostra $\vec{e}$ um parāmetro que reflete o grau de alteraçäo de maneira mui to sensivel, procurou-se relacionar esta variāvel com um îndice de alteraçăo, calculävel a partir das anälises quĩmi cas. Foi selecionado o indice $i=\left(\mathrm{A}_{2} \mathrm{O}_{3}+\mathrm{Fe}_{2} \mathrm{O}_{3}\right) / \mathrm{MgO}$, definido por Wackermann 1975, e adaptado a rochas com baixo teor em $\mathrm{Na}$ e $\mathrm{Ti}$.

A figura 22 mostra a variaçáo de log $i$ com a densidade aparente de cerca de 70 amostras do segundo gru po. Para as amostras classificadas como rocha dura e saprolito grosseiro, a relaçäo $\log i=f(D A) \vec{e}$ linear e segue a equação $\log i=-0,30 \mathrm{DA}+0,15$. Para a laterita amarela a re lação, tambëm Tinear, è da forma $\log i=-3,23 \mathrm{DA}+3,84$. As 


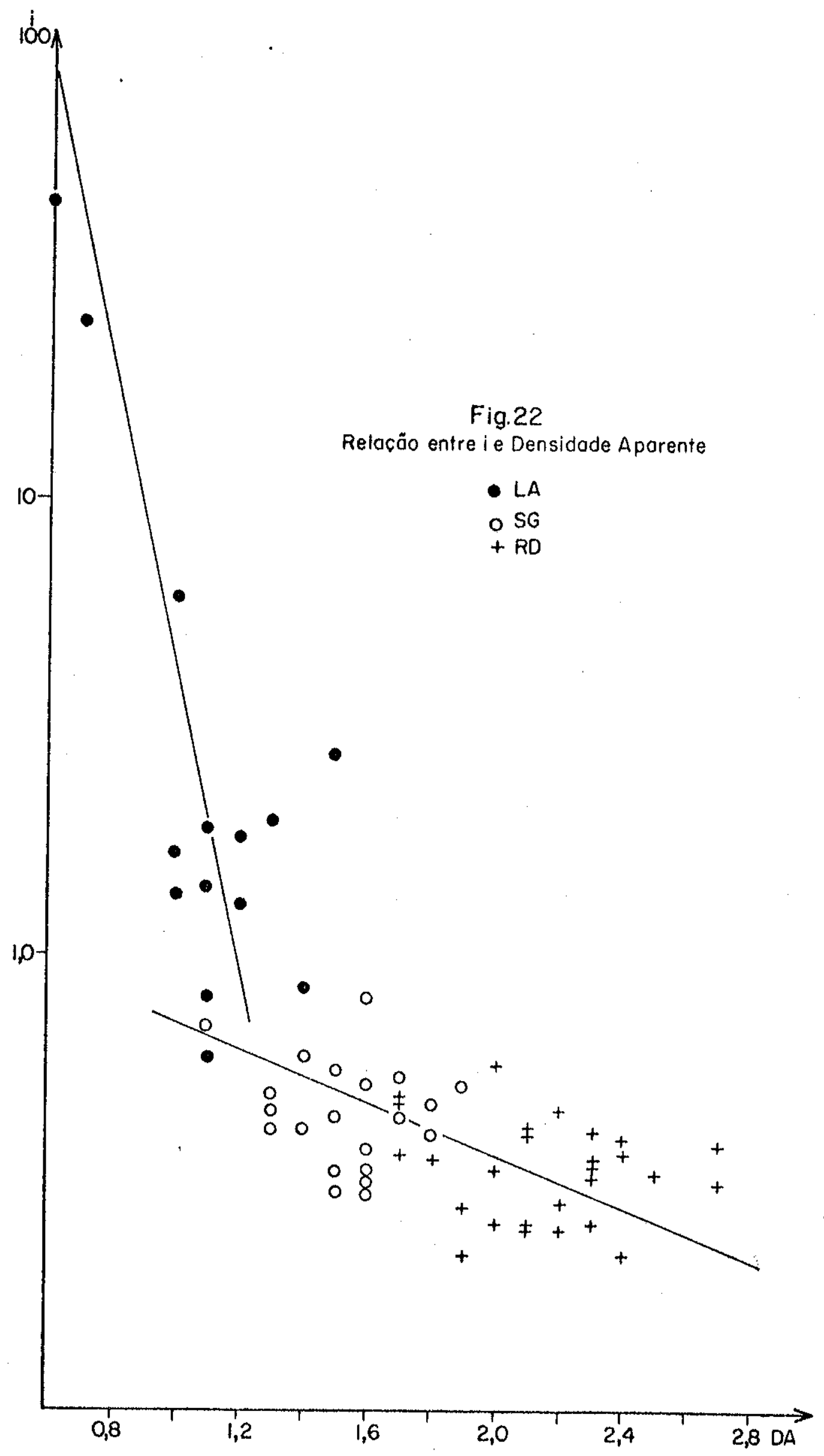


amostras agrupadas em torno da reta de maior coeficiente an gular, correspondendo aos valores de $i$ mais baixos, representam uma primeira fase de alteração, incipiente, que se dă com a conservação da serpentina. o outro segmento de reta corresponde a uma alteração mais profunda, com dissolução de serpentina.

A partir da anālise da figura 22, levando-se em conta que as lateritas vermelhas tipicas apresentam geralmente valores de $i$ maiores que 20 , decidiu-se considerar:

$$
\begin{aligned}
& \text { RD } i \leqslant 0,4 \\
& \text { SG } 0,4<i \leqslant 1,0 \\
& \text { LA } 1,0<i \leqslant 20 \\
& \text { LV } i>20
\end{aligned}
$$

Estabelecidos estes limites, foi possivel pas sar ao estudo dos dados quimicos fornecidos pela Mineradora, afim de caracterizar, quanto à composição química, os diferentes fäcies de alteração.

a. A evolução dos dunitos

\section{a.1. Topossequēncias XV e E6}

Os diferentes fäcies de alteração apresentam composição quỉmica mëdia constante da tabela 7. Estes valores estão representados na figura 23 , em função da profundi dade mëdia de amostragem de cada fäcies. Percebe-se claramente que os elementos dosados podem ser classificados em 2 grupos:

rados $(\mathrm{Cu}, \mathrm{Al}, \mathrm{Cr}, \mathrm{Co}, \mathrm{Fe})$;

- os que se concentram nos fäcies mais alte-

- os que diminuem de teor nos fäcies mais al 
TABELA 7

COMPOSIÇAO QUIMICA MEDIA (: EM PESO DO METAL) DOS FACIES DE ALTERAÇA SOBRE DUNITO. DADOS DAS TOPOSSEQUEICIAS XV E EG

\begin{tabular}{|c|c|c|c|c|c|c|c|c|}
\hline & & $R D$ & & $S G$ & & LA & & LV \\
\hline $\mathrm{Mg}$ & 19,8 & $(2,1)^{*}$ & 17,0 & $(2,9)$ & 6,4 & $(3,9)$ & $i, 2$ & $(0,4)$ \\
\hline $\mathrm{Fe}$ & 7,2 & $(1,4)$ & 10,6 & $(2,4)$ & 25,7 & $(1], 5)$ & 45,6 & $(6,4)$ \\
\hline $\mathrm{Cr}$ & 0,6 & $(0,3)$ & 0,4 & $(0,4)$ & 1,5 & $(7,4)$ & 3,0 & $(1,1)$ \\
\hline $\begin{array}{l}\text { Co } \\
\text { (ppin) }\end{array}$ & 158 & $(62)$ & 184 & $(61)$ & 443 & $(224)$ & 828 & $(265$ \\
\hline $\begin{array}{c}\text { Cu } \\
\text { (ppm) }\end{array}$ & 8 & $\left(\begin{array}{l}5\end{array}\right)$ & 25 & $(79)$ & 52 & $(33)$ & 59 & 117 \\
\hline$S i$ & 21,5 & $(2,3)$ & 20,8 & $(3,1)$ & 17,3 & $(7,9)$ & 7,3 & $(4,7)$ \\
\hline Al & 0,3 & $(0,7)$ & 2,0 & $(i, \overline{0})$ & 3,8 & $(2,6)$ & 6,0 & $(2,9)$ \\
\hline $\mathrm{Ni}$ & 0,97 & $(0,67)$ & 0,88 & $(0,65)$ & 1,38 & $0,73)$ & 0,70 & $(0,3)$ \\
\hline$i$ & 0,33 & $(0,07)$ & 0,69 & $(0,10)$ & 7,05 & $(5,75)$ & 45,50 & $(25,80)$ \\
\hline $\begin{array}{l}\text { profund. } \\
\text { mëdia (m) }\end{array}$ & 5,5 & & 5,0 & & 4,2 & & 1,7 & \\
\hline
\end{tabular}

* Dados entre parēnteses = desvio padrão 

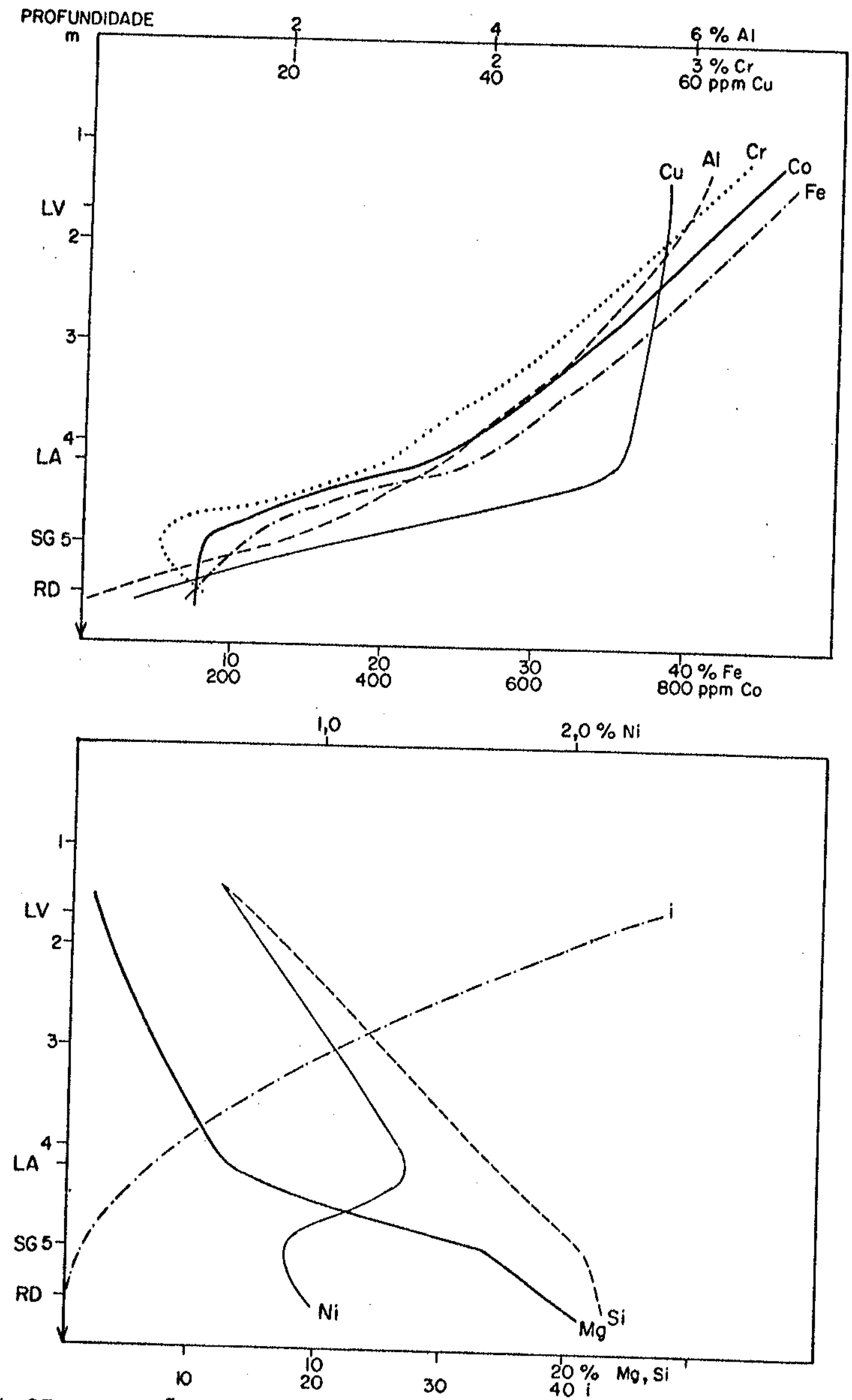

Fig.23 - VARIACÃO DOS TEORES MÉDIOS COM PROFUNDIDADES MÉDIAS TOPOSSEQUENNCIAS XV \& EG 
terados (Si, Mg).

O Ni apresenta um comportamento especial, atin gindo teores māximos em horizontes intermediārios do perfi] de alteração.

Dentre os elementos cujo teor aumenta nos horizontes mais superficiais, tem-se um comportamento bastante semelhante para o $\mathrm{Al}, \mathrm{Cr}$, $\mathrm{Co}$ e Fe. O Cu segue aproximadamente a mesma tendēncia de enriquecimento contīnuo atē o nível de LA para, a partir da $\bar{i}$, manter-se praticamente constante. Quanto aos elementos eliminados do perfil, o $\mathrm{Mg}$ o $\overline{\mathrm{e}}$ mais prontamente e em maior intensidade que o si.

Com a finalidade de quantificar a noção de se melhança ou diferença no comportamento quïmico dos elementos durante o processo de alteração, foram calculados os coefi cientes de correlação Pearson entre cada par dos 8 elementos dosados, atravēs do programa PEARSON CORR do conjunto SPSS, implantado no Centro de Computação Eletrōnica da USP. OS vaTores obtidos são indicados na figura 24.

Os valores assumidos pelo coeficiente Pearson situam-se entre -1 e +1 , permitindo testar o desvio com rela ção à hipötese nula de ausēncia de correlação linear entre $x$ e y (caso de $r=0)$, a um dado nîvel de significância.

No que concerne os elementos maiores, Si, $\mathrm{Fe}$ e $\mathrm{Mg}$, os coeficientes de correlação positivos ou negativos podem mostrar-se elevados apenas devido ao fato de serem expressos em porcentagens ponderais de soma constante (Chayes 1960). Porisso ē indispensāvel escolher um nīvel de significāncia elevado, affim de diminuir a influência desses efeitos de cālculo. Assim, a hipötese nula de independência de $x$ com relação a y serā rejeitada para uma probabilidade de 0,001. A ceitando esse limite, percebe-se na figura 24 o comportamento contrastante de 4 grupos de elementos: 
FIGURA 24

COEFICIENTES DE CORRELAÇAO PEARSON ENTRE OS TEORES DE Mg, $\mathrm{Fe}, \mathrm{Cr}, \mathrm{Co}, \mathrm{Cu}, \dot{\mathrm{Si}}, \mathrm{Al}$ e $\mathrm{Ni}$ (284 amostras)

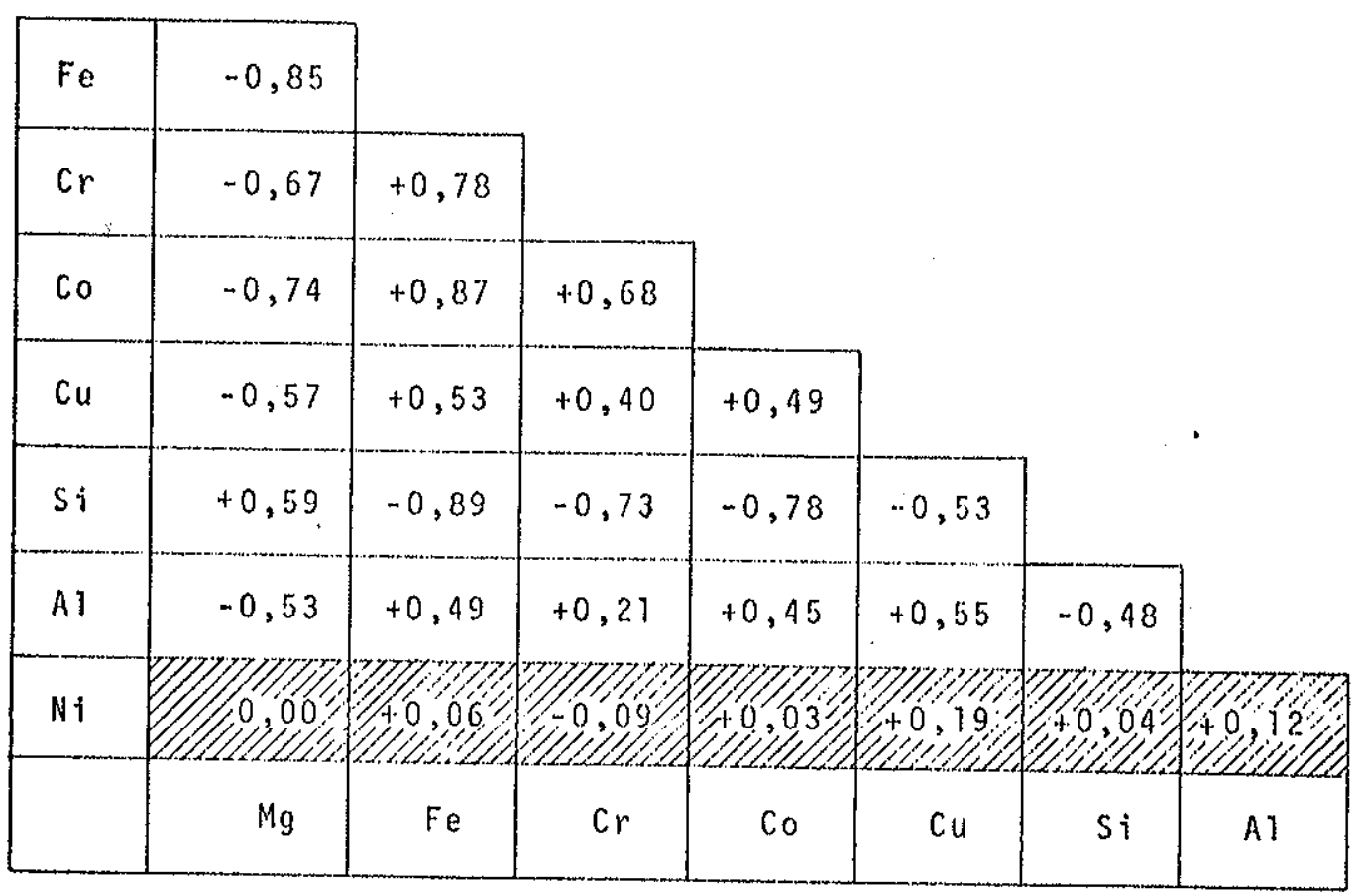

Rejeiçäo da hipötese Ho (não existe correlação linear entre os pares) para uma probabilidade de 0,001

Aceitação da hipötese Ho para probabilidade de 0,001 
- Co, Cr e Fe,tomados 2 a 2, apresentam fortes correlações positivas entre si, e fortes correlações negativas com o Si e o $\mathrm{Mg}$;

- Cu e Al apresentam correlação positiva näo muito alta entre si, e correlação negativa e não muito alta com Si e Mg;

- Si e Mg apresentam entre si correlação po sitiva e correlações negativas com o $\mathrm{Cu}, \mathrm{Al}, \mathrm{Cr}, \mathrm{Co}$ e Fe;

- 0 Ni não apresenta correlações significativas com nenhum outro elemento.

A figura $25 \mathrm{~A}$ relaciona os coeficientes de correlaçăo dos 8 elementos em função dos coeficientes de correlação do $\mathrm{Fe}$ edo Si, elementos que apresentam entre si o coeficiente de correlação negativo mais alto em valor absoluto. Nesta figura surge, com maior clareza ainda, os 4 grupos de elementos acima mencionados.

A fim de detalhar o estudo do comportamento do $\mathrm{Ni}$, foram calculados seus coeficientes de correlação com o Fe e o Si em cada subconjunto representativo de cada fäcies de alteração. Os resultados constam da figura 25B e, de modo geral, confirmam sua tendência para o enriqueci mento da rocha dura atê a laterita amarela e o. posterior empobrecimento em direção aos nïveis mais alterados. E inte ressante notar que, no inicio do processo (RD), o $\mathrm{Ni}$ comporta-se como um elemento do grupo de $\mathrm{Fe}, \mathrm{Cr}$ e $\mathrm{Co}$, concentran do-se,portanto, à medida que a alteração aumenta.Na LV esta tendência inverte-se,e o $\mathrm{Ni}$ mostra correlação positiva com os elementos solüveis. Neste caso, quanto menos evoluida a $L V$, mais $\mathrm{Ni}$ ela contëm. Nos fācies intermediärios (SG e LA), as correlações são fracas e é justamente nestes horizontes que se encontram os maiores teores de $\mathrm{Ni}$ de todo o perfil de alteração. 


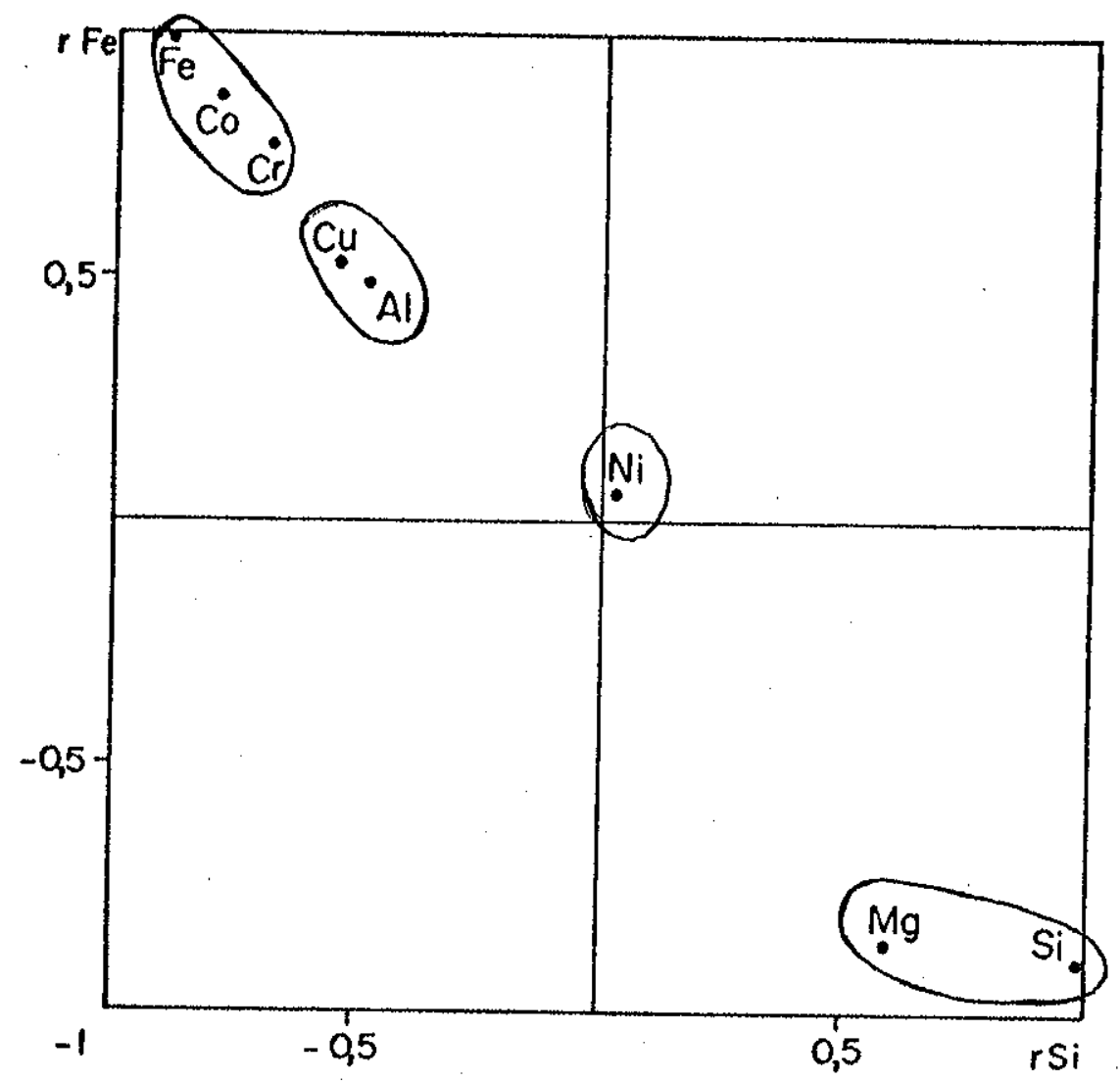

Fig 25ARepresentaçāo gráfico dos coeficientes de correlação do $\mathrm{Mg}$, $\mathrm{Fe}, \mathrm{Cr}, \mathrm{Co}, \mathrm{Cu}, \mathrm{Si}, \mathrm{Al}$ e $\mathrm{Ni}$ em função dos coeficientes de correlação do Fe e do Si. 


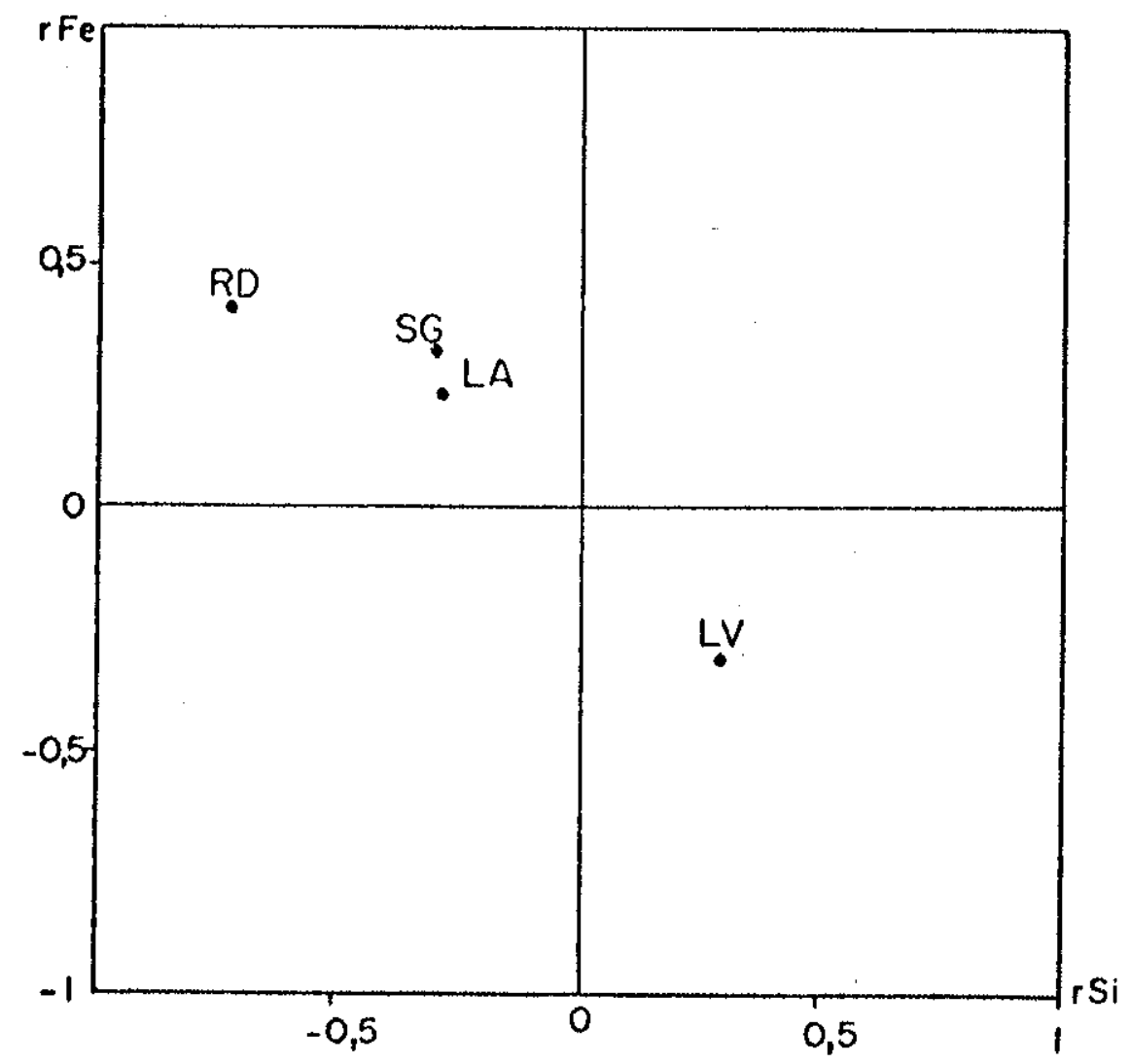

Fig25B Representoção gráfica dos coeficientes de correlação do Ni, com o $\mathrm{Fe}$ e $\mathrm{Si}$ nos diferentes fócies de alteroção. 
a.2. Topossequencias XXVII, W4 e perfil G

a.2.1. Evolução geral dos elementos químicos durante a a 1 teração

0 resultado das anālises quĩmicas de 104 amostras de dunito serpentinizado e de seus produtos de alte ração consta do Apēndice I. Na tabela 8 tem-se os valores mëdios de cada oxido em cada horizonte, respeitando-se aqui o criterrio assumido para o tratamento das amostras cedidas pela Mineradora, quanto aos intervalos de variação do indice de alteração em cada fäcies. Neste caso, a representação dos teores em função da profundidade mëdia de cada horizonte não faz sentido porque, ao conträrio dos dados das topos sequências XV e E6,que se locializam inteiramente na planicie, as topossequencias aqui consideradas dispõem-se cortan do os vārios segmentos da paisagem e, como jā se viu anteriormente, a distribuição dos fäcies de alteração varia em. função do sïtio topogräfico.

A tabela 8 apresenta, de modo geral, valores semelhantes aos da tabela 7 , levando-se em conta os fatores multiplicativos de passagem do metal ao óxido correspondente; Cabe apenas assinalar que,para as topossequencias XV e E6,os valores de $\mathrm{SiO}_{2}$ e de $\mathrm{Al}_{2}{ }_{2}{ }_{3}$ são mais altos, e os de CuO mais baixos que para as topossequencias XXVII, WA e perfil G. Isto se deve,talvez, a uma composição mais peridotïtica para as rochas da topossequência E6, localizada próximo à borda do maciço. Os valores de NiO na rocha dura, apresentados na tabela 8 ,são muito baixos porque, neste caso, trata-se de amostras de rocha excluídos os veios de garnierita, que foram analisados separadamente.

Confirmando as tendências $j \bar{a}$ assinaladas, per cebe-se novamente a existência de um grupo de elementos residuais, cujo teor aumenta durante o processo de alteração 


\section{TABELA 8}

COMPOSIÇAO QUIMICA MEDIA (\% EM PESSO DO OXIDO) DOS FACIES DE ALTERAÇAO SOBRE DUNITO. DADOS DAS TOPOSSEQUENCTAS XXVII, W4 E DO PERFIL G

RD

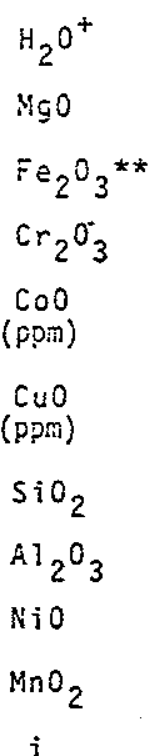

$\mathrm{SiO}_{2} / \mathrm{MgO}$

$\mathrm{SiO}_{2} / \mathrm{Fe}_{2} \mathrm{O}_{3}$ $\mathrm{MnO}_{2} / \mathrm{COO}$$$
0,20
$$$$
1,23
$$$$
3,94
$$$$
8,3
$$

SG

$$
\begin{aligned}
& 12,8 \\
& 3 \hat{3}, 4 \quad(3,4) * \\
& 10,4(2,1) \\
& 0,44(0,2)
\end{aligned}
$$$$
240(92)
$$$$
38 \text { (3) }
$$$$
41,0(3,5)
$$$$
0,5(0,3)
$$$$
0,33(0,07)
$$$$
0,33(0,07)
$$

$$
\begin{aligned}
& 12,2 \\
& 28,3(4,5) \\
& 15,5(2,3) \\
& 0,64(0,4)
\end{aligned}
$$$$
284 \quad(59)
$$$$
49 \quad(58)
$$$$
40,8(6,4)
$$$$
0,7(0,9)
$$$$
0,91(0,70)
$$$$
0,28
$$$$
0,60(0,12)
$$$$
7,44
$$$$
2,63
$$$$
9,8
$$

LA

$$
\begin{array}{r}
8,9 \\
.9,9(7,0) \\
39,0(.13,8) \\
4,10(3,2)
\end{array}
$$$$
630
$$$$
\text { (274) }
$$$$
93(41)
$$$$
32,9(14,9)
$$$$
2,4(1,6)
$$$$
1,40(0,67)
$$$$
0,44
$$$$
7,5(6,0)
$$$$
3,32
$$$$
0,84
$$$$
7,0
$$

LV

$$
\begin{array}{rrr}
5,2 & \\
1,6 & (0,5) \\
70,8 & (3,9) \\
6,20 & (1,9) \\
1451 & (1087) \\
106 & (34) \\
10,1 & (2,5) \\
3,5 & (1,4) \\
1,19 & (10,5) \\
1,01 & \\
50,9 & (17,0) \\
6,31 & \\
0,14 & \\
7,0 &
\end{array}
$$

** Fe total computado como $\mathrm{Fe}^{3+}$ 
(Fe, Cr, Co, Cu e Al), e de um grupo de elementos solūveis, de teor decrescente ( $\mathrm{Si}$ e $\mathrm{Mg}$ ). $\mathrm{O} \mathrm{Mn}$, dosado nestas amostras, segue o comportamento dos residuais. 0 teor em $\mathrm{H}_{2} \mathrm{O}^{+}$ permanece mais ou menos constante na passagem RD-SG, para diminuir em seguida. O Ni mostra um enriquecimento nos pri meiros estāgios, seguido de uma Tigeira diminuição na LV. $\bar{A}$ dosagem do $\mathrm{Ca} 0$, feita em algumas poucas amostras, indica teores sempre baixos (inferiores a $0,5 \%$ ) e muito variāveis.

0 estudo comparativo do comportamento dos elementos durante a alteração pode ser facilitado pelo uso do parâmetro "taxa de concentração", razão entre o teor num nivel dado e o teor na rocha fresca. Os aumentos de teor são caracterizados por valores da taxa de concentração superiores a 1 e as diminuições, por valores inferiores a 1 .

A tabela 9 mostra estes călculos para as amostras das topossequencias XXVII, W4 e do perfil $G$, tomando como referencia a anālise do dunito serpentinizado constante da tabela 2. De novo, as mesmas tendências apare cem: taxas inferiores a 1 para $0 \mathrm{MgO}$ e $\mathrm{SiO}_{2}$ e superiores a 1 para os demais componentes.

Entretanto, esta referēncia, mëdia de 2 anä lises de rocha fresca, não parece ser bem representativa dos dunitos serpentinizados de Santa Fé, principalmente por seu alto teor em $\mathrm{FeO}(13,15 \%)$, baixo teor em $\mathrm{SiO}_{2}$ $(36,34 \%)$ e baixissimo teor em $\mathrm{Al}_{2} \mathrm{O}_{3}(0,16 \%)$. As rochas qua se frescas das topossequências XXVII e W4 indicam sempre teores bem mais baixos em $\mathrm{Fe}$, elemento que sō pode tender à concentração relativa, devido à sua notória estabilidade no meio considerado.

Em vista disso, decidiu-se calcutar a compo sição quỉmica de uma rocha fresca mëdia hipotética, partin do da anālise quỉmica de seus principais componentes.Admi- 


\section{TABELA 9}

TAXAS DE CONCENTRAÇAO DOS VARIOS OXIDOS EM RELAÇAOO A ROCHA FRESCA

$\begin{array}{lllll}R & R D & S G & L A & L V\end{array}$

$\begin{array}{cccccc}\mathrm{H}_{2} \mathrm{O}^{+} & 1,00 & 1,73 & 1,65 & 1,20 & 0,70 \\ \mathrm{MgO} & 1,00 & 0,81 & 0,69 & 0,24 & 0,04 \\ \mathrm{Fe}_{2} \mathrm{O}_{3} & 1,00 & 0,71 & 1,06 & 2,68 & 4,86 \\ \mathrm{Cr}_{2} \mathrm{O}_{3} & 1,00 & 1,26 & 1,83 & 11,71 & 17,70 \\ \mathrm{CoO} & 1,00 & 1,20 & 1,42 & 3,15 & 7,26 \\ \mathrm{CuO} & 1,00 & 1,27 & 1,63 & 3,10 & 3,53 \\ \mathrm{SiO}_{2} & 1,00 & 1,13 & 1,12 & 0,91 & 0,28 \\ \mathrm{Al}_{2}{ }^{0} 3 & 1,00 & 3,13 & 4,38 & 15,00 & 21,90 \\ \mathrm{NiO} & 1,00 & 1,43 & 3,96 & 6,09 & 5,17 \\ \mathrm{MnO}_{2} & 1,00 & 1,00 & 1,27 & 2,00 & 4,59\end{array}$


tiu-se que o processo de serpentinização respeitou cerca de um terço da olivina, e deu-se com certa perda de Mgo,premis sas compatīveis com as anäises modais e com as considerações sobre a serpentinização, constantes do capittulo I. Na tabela 10 estão os dados de partida e a composição calculada. Para o $\mathrm{Cr}, \mathrm{Co}, \mathrm{Cu}$ e $\mathrm{Ni}$ foram mantidos os dados originais da tabela 2 e, para o Al, recalculou-se seu teor, assumindo uma taxa de enriquecimento idêntica à do Fe, na passa gem rocha fresca-rocha dura.

A tabela 11 mostra as taxas de concentração recalculadas em função dos novos valores. No inĩcio da alte ração, os 5 elementos residuais, $\mathrm{Fe}, \mathrm{Cr}, \mathrm{Co}, \mathrm{Cu}$ e Al, apresentam, todos, taxas de concentração da mesma ordem de gran deza. $0 \mathrm{Fe}, \mathrm{Al}$ e Co mantëm comportamento semelhante at $\vec{e} \quad 0$ fim, enquanto que o $C u$ conserva na $L V$ a mesma taxa que na LA. O Cr é o elemento relativamente mais enriquecido, e o $\mathrm{Ni} \overline{\mathrm{e}}$ o ünico que apresenta a maior taxa de enriquecimento na $L A$.

A descrição do comportamento quĩmico dos elementos durante a alteração vem corroborar e detalhar as conclusões sobre a evolução mineralögica.

Em resumo, quanto aos elementos maiores ( $\mathrm{Si}$, $\mathrm{Mg}$ e $\mathrm{Fe}$ ), o decrëscimo dos teores de $\mathrm{Si}$ e $\mathrm{Mg}$ e o acrëscimo dos teores de Fe reflete a destruição dos silicatos hipögenos (olivina e serpentina) e a concomitante formação dos oxidos e hidrōxidos de Fe. 0 Mg parte em solução sob forma de $\mathrm{Mg}(\mathrm{OH})_{2}$ altamente solüvel e a sĩlica è evacuada tambēm em solução, como $\mathrm{H}_{4} \mathrm{SiO}_{4}$ (Krauskopf 1956, Pickering 1962).

A razão $\mathrm{SiO}_{2} / \mathrm{MgO}$, calculada para os diferentes fácies de alteração (tabela 8), mostra que a destruiçăo dos silicatos é violenta a partir de LA e que ocorre por evacuação praticamente completa do $\mathrm{Mg}$ e parcial do Si.os teo res de $\mathrm{SiO}_{2}$ na rocha dura e $S G$, 1 igeiramente mais altos que 
TABELA 10

CALCULO DA COMPOSICAO QUTHICA DO DUNITO SERPENTINIZADO, A PARTIR DE SEUS CONSTITUINTES

\begin{tabular}{|c|c|c|c|c|c|c|c|}
\hline & $\mathrm{H}_{2} \mathrm{O}^{+}$ & $\mathrm{SiO}_{2}$ & MgO & $\mathrm{FeO}$ & Densidade & \%volume & \%massa \\
\hline 0livina & - & 40,6 & 45,1 & 10,7 & 3,30 & 35 & 42,1 \\
\hline Serpentina & 14,0 & 40,8 & 36,5 & 6,4 & 2,45 & 62 & 55,3 \\
\hline Bructta & 30.88 & - & 69.1 & - & 2,40 & 3 & 2,6 \\
\hline
\end{tabular}

$\begin{array}{lcccc} & \mathrm{H}_{2} \mathrm{O}^{+} & \mathrm{SiO}_{2} & \mathrm{MgO} & \mathrm{FeO} \\ \text { Olivina } & - & 17,09 & 20,00 & 3,54 \\ \text { Serpentina } & 7,74 & 22,56 & 20,18 & 4,50 \\ \text { Erucita } & 0,80 & \ldots & 1,80 & -\end{array}$

Contribuição de cada constituinte ä rocha hipotẽtica

\begin{tabular}{|c|c|c|c|c|c|c|c|c|c|c|c|}
\hline densidade & $\mathrm{H}_{2} \mathrm{O}^{+}$ & $\mathrm{SHO}_{2}$ & $\mathrm{MgO}$ & $\mathrm{Fe}_{2} \mathrm{O}_{3}^{*}$ & $\mathrm{Cr}_{2} \mathrm{O}_{3}$ & $\mathrm{Al}_{2} \mathrm{O}_{3}$ & $\mathrm{HnO}_{2}$ & NiO & $\mathrm{COO}$ & CuO & Total \\
\hline 2,75 & 8.54 & 39,65 & 41,98 & 8,91 & 0,35 & 0.42 & 0,22 & 0,23 & 0,020 & $0,003$. & 100,30 \\
\hline
\end{tabular}

* Fe0 calculado como $\mathrm{Fe}_{2} \mathrm{O}_{3}$ 
TABELA 11

TAXAS DE CONCENTRAÇAO DOS VARIOS OXIDOS

EM RELAÇAO A ROCHA FRESCA HIPOTETICA

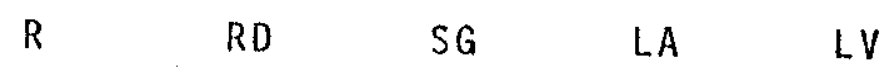

$\begin{array}{cccccc}\mathrm{H}_{2} \mathrm{O}^{+} & 1,00 & 1,50 & 1,43 & 1,04 & 0,61 \\ \mathrm{Mg} 0 & 1,00 & 0,80 & 0,77 & 0,24 & 0,04 \\ \mathrm{Fe}_{2} \mathrm{O}_{3} & 1,00 & 1,16 & 1,74 & 4,40 & 7,94 \\ \mathrm{Cr}_{2} \mathrm{O}_{3} & 1,00 & 1,26 & 1,83 & 11,70 & 17,70 \\ \mathrm{Co0} & 1,00 & 1,20 & 1,42 & 3,15 & 7,26 \\ \mathrm{CuO} & 1,00 & 1,27 & 1,63 & 3,10 & 3,53 \\ \mathrm{SiO}_{2} & 1,00 & 1,03 & 1,03 & 0,83 & 0,25 \\ \mathrm{Al}_{2} \mathrm{O}_{3} & 1,00 & 1,20 & 1,70 & 5,70 & 8,30 \\ \mathrm{NiO} & 1,00 & 1,43 & 3,96 & 6,09 & 5,17 \\ \mathrm{MnO}_{2} & 1,00 & 1,00 & 1,30 & 2,00 & 4,60\end{array}$


na rocha fresca, podem refletir o fenōmeno de silicificação que ocorre nos primeiros estāgios da alteração. 0 comportamento do $\mathrm{Fe}_{2} \mathrm{O}_{3}$ em relação à $\mathrm{SiO}_{2}$ è evidenciado pelo cālculo das razões $\mathrm{SiO}_{2} / \mathrm{Fe}_{2} \mathrm{O}_{3}$ (tabela 8 ), que evoluem decrescendo, no inicio lentamente, e bruscamente a partir da LA.

0 estudo experimental da alteração de serpen tinitos (Pedro $\xi$ Bittar 1966) mostrou que, nas mais variadas situações de $\mathrm{pH}$ e de temperatura, a razão $\mathrm{SiO}_{2} / \mathrm{R}_{2} \mathrm{O}_{3}(\mathrm{R}=$ $\Sigma$ cátions trivalentes) decresce da rocha fresca para os pro dutos de alteração. A razão $\mathrm{SiO}_{2} / \mathrm{MgO}$, entretanto, mostra com portamento variāvel, dependendo das condições de drenagem e de pH. Para drenagem intensa, em meio neutro ou ligeiramente ācido, a razão $\mathrm{SiO}_{2} / \mathrm{MgO}$ decresce do material fresco para - material alterado, e o conträrio ocorre em meio äcido. Pa ra condições de drenagem dificultadas, a alteração se dá com aumento da razão $\mathrm{SiO}_{2} / \mathrm{MgO}$.

A alteração das rochas de Santa $F \vec{e}$, levando a um decrēscimo da razão $\mathrm{SiO}_{2} / \mathrm{Fe}_{2} \mathrm{O}_{3}$ e um aumento da razão $\mathrm{SiO}_{2} / \mathrm{MgO}$ da rocha fresca aos horizontes mais alterados, pode ser interpretada à luz do modelo experimental. Teriam es sas rochas evoluĩdo sob condições de drenagem não muito intensas, pois que a hipōtese de um meio de acidez elevada não è compatĩvel com a situação real.

0 teor de àgua de constituição $\left(\mathrm{H}_{2} \mathrm{O}^{+}\right)$mantëm se aproximadamente constante no inicio da alteração, para de pois diminuir. E que, logo nos primeiros estägios, 4 diferentes fatores entram em jogo:

- a dissolução da olivina, que faz com que o teor em serpentina e, portanto, em ägua, aumente relativamente;

- formação residual de amorfos mais ou menos

hidratados; 
- destruição da serpentina, correspondendo à queda de teores em $\mathrm{H}_{2} \mathrm{O}^{+}$;

$\mathrm{H}_{2} \mathrm{O}^{+}$.

- cristalização da goethita com alto teor em

Tudo isto acontece mais ou menos ao mesmo tempo, sendo que os 2 primeiros fatores se dão no mesmo sentido e predominam no inicio, e os 2 ūttimos são antagōnicos e predominam no fim. No material jä bem evolü̈do (LV), ocorre a desidratação da goethita e formação de hematita, com consequente redução em $\mathrm{H}_{2} \mathrm{O}^{+}$.

Os demais elementos quimicos dosados sofrem um processo de enriquecimento durante a alteração. 0 mais fortemente concentrado ē o cr,principalmente a partir do ni vel de LA. Seu aumento relativo deve ser atribuĩdo à concentração residual de cromita. 0 Al, contido principalmente nas vermiculitas, talvez na cromita, e, em pequena quantidade,na goethita, deve sua concentração à acumulação residual dos 2 primeiros minerais e à neoformação do terceiro. 0 Mn e o co, geralmente associados por afinidade geoquïmica, têm taxas de concentração intermediārias. A razão $\mathrm{MnO}_{2} / \mathrm{COO}$ decresce com a alteração, o que sugere perda relativa do primeiro elemento com relação ao segundo. $0 \mathrm{Cu}$, embora sendo elemento de al ta solubilidade, apresenta enriquecimento nas partes superio res do perfil. Sua vinculação mineralógica ē desconhecida.

A evolução do Ni è a mais complexa. De valo res bastante baixos na rocha fresca e na rocha pouco alterada (sem considerar os veios de garnierita), atinge teores de cerca de $1 \%$ no SG e $1,5 \%$ na $L A$, para decrescer 1 igeiramente na LV. Parece ter comportamento bastante independente dos ou tros elementos, não apresentando correlações significativas com nenhum deles (figura 25A). Sua distribuição no espaço es tă representada nas figuras $26,27,28$ e 29. Comparando com as figuras $15,16,17$ e 18 , que mostram a repartição dos fácies de 


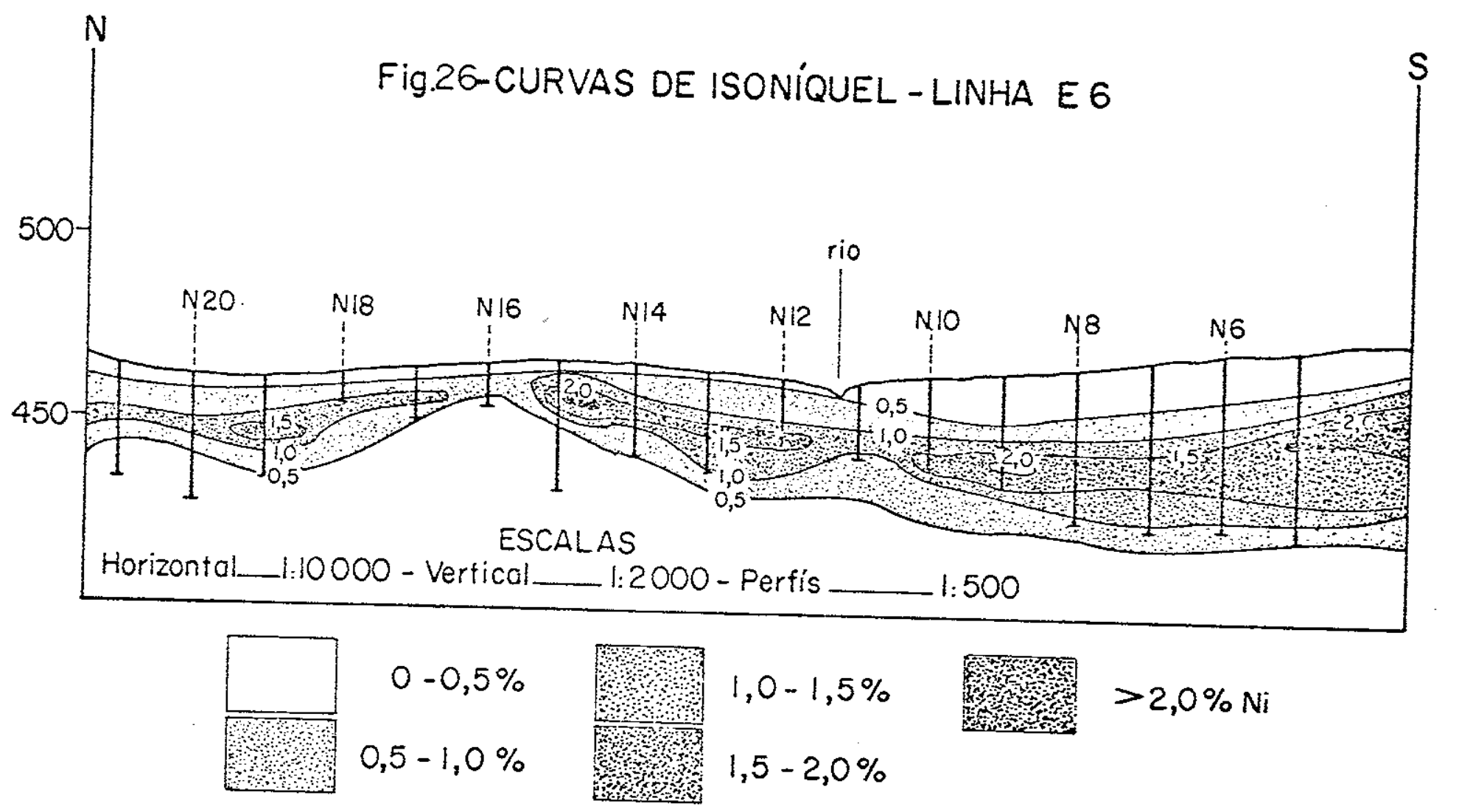




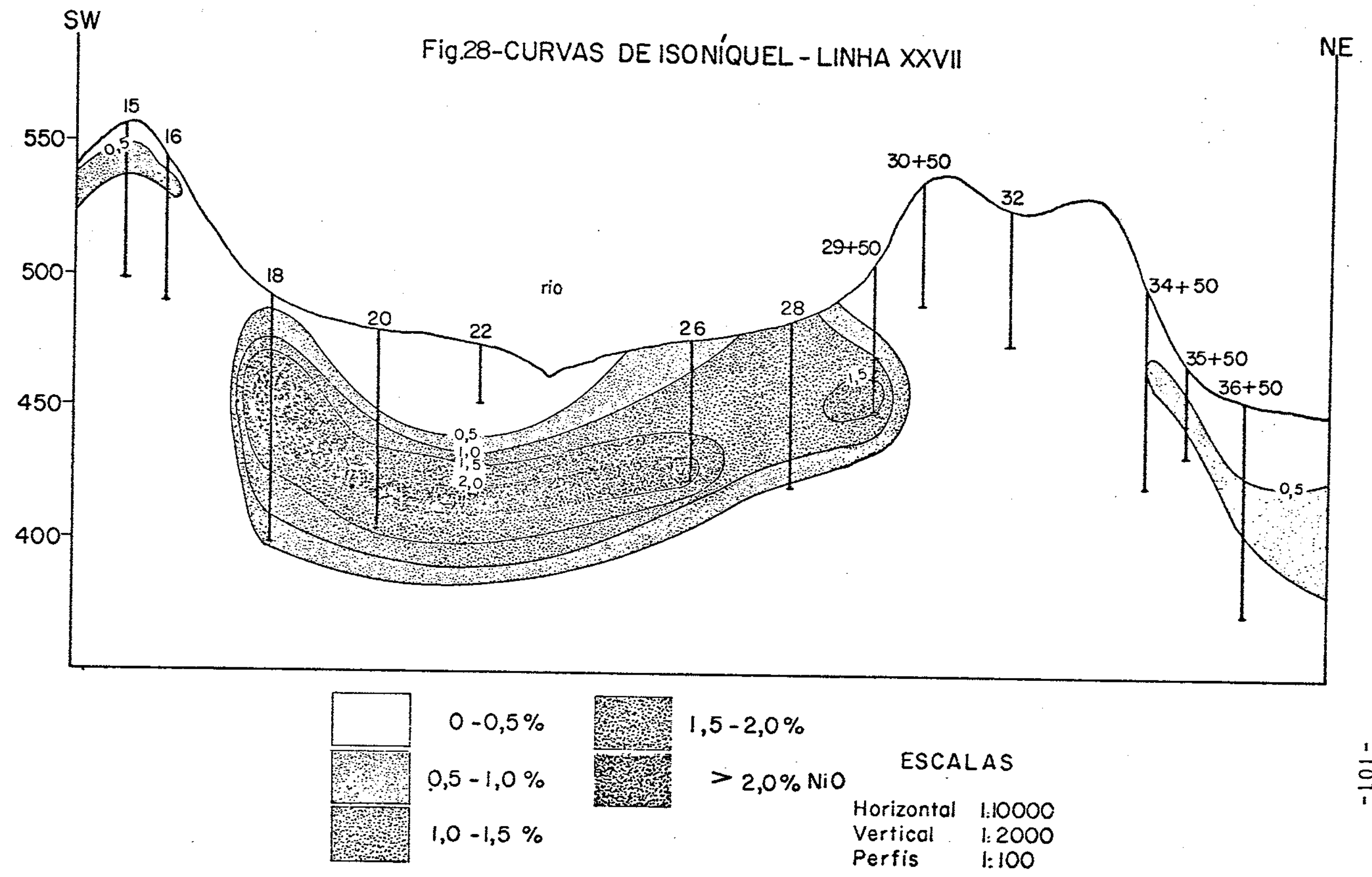




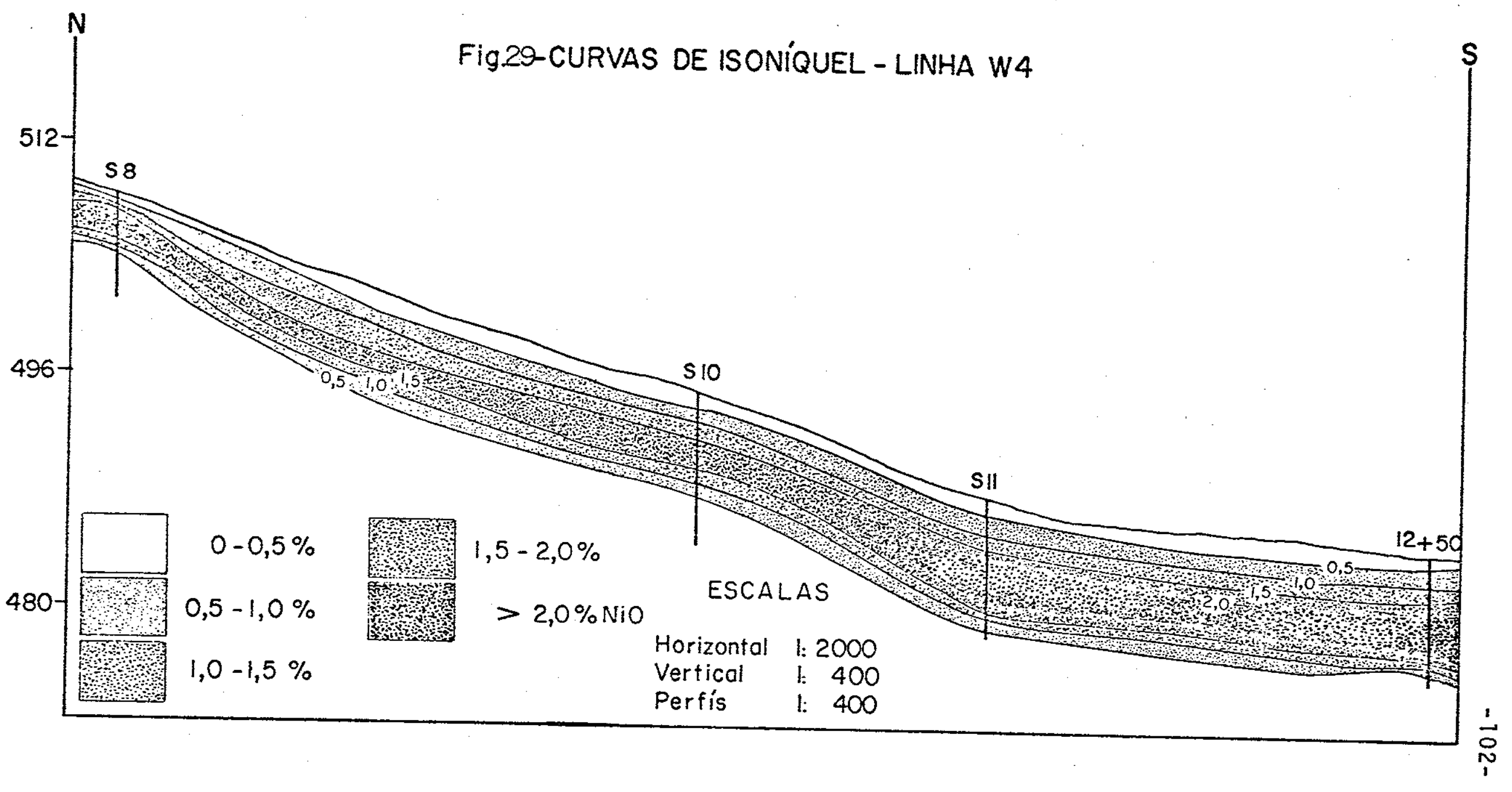


alteração sobre as mesmas topossequências, fica evidente que :

- as concentrações de $\mathrm{Ni}$ estão associadas aos perfis de alteração mais desenvolvidos, dando-se portan to nos sopés e principalmente nas baixadas;

de baixada;

- o teor de $\mathrm{NiO}$ excede $2 \%$ apenas em região

- os valores mäximos alcançados pelo $\mathrm{Ni}$ situam-se no topo do $S G$ e na $L A$;

- a LV pode apresentar-se enriquecida em $\mathrm{Ni}$, principalmente em sua parte basal, como ē bem evidente nos perfis de baixada da topossequencia XXVII; trata-se aĩprovavelmente, de material coluvionar proveniente das zonas mais altas, em vias de sofrer nova pedogênese;

- teores de NiO que ultrapassam $1 \%$ começam a ser encontrados a partir de uma profundidade mēdia de $2 \mathrm{~m}$; 0 limite inferior para a curva isoni de $1 \%$ varia de 4 a $10 \mathrm{~m}$.

a.2.2. Distribuição dos elementos quĩmicos nos mine rais

As anālises quĩmicas efetuadas sobre amostra total deram informações a respeito da evolução geral do com portamento dos elementos químicos no perfil de alteração. No entanto, o problema da repartição dos elementos químicos nas diferentes fases mineralögicas sō póde ser abordado com a realização de anālises dos minerais; quando isto não foi possĩvel, tentou-se deduzí-la indiretamente,pela anālise de misturas de minerais, de certas frações granulométricas, e por ataques quimicos parciais. 
a.2.2.1. Anāitise quĩmica dos minerais

\section{Minerais Hipögenos}

As composições quĩmicas e as förmulas estruturais, calculadas segundo Deer et al. 1963, de alguns minerais hipógenos constam da tabela 12. A olivina e o piroxe् nio foram analisados por microssonda eletrōnica (Souza 1978). A composição da serpentina foi calculada a partir da anālise de uma mistura de serpentina e vermiculita (66 am), sendo que todo o Al foi atribuỉdo a este ültimo mineral. A ver miculita teve sua composição quĩmica determinada a partir da anālise de 2 amostras de veios (T9-am e T9-ve).

Comparando o teor em NiO da olivina $(0,35 \%)$ com o da serpentina $(0,27 \%)$, percebe-se que a razão entre esses dois valores ē muito prōxima da razão entre as densidades desses dois minerais $(3,3 / 2,6)$. Isto parece indicar que não houve perda de $\mathrm{Ni}$ durante a serpentinização (Edel' shtein 1960).

A vermiculita e o piroxênio apresentam teores de $\mathrm{Ni}$ sensivelmente mais baixos que os da olivina ou da serpentina.

\section{Produtos de Alteração}

Em geral, os materiais que constituem os pro dutos de alteração ocorrem associados entre si ou a minerais hipögenos. Pelo fato de se apresentarem finamente divi didos, è muito dificil separā-los num grau de pureza razoāvel. Porisso, muitas amostras analisadas são misturas. E en tão necessārio o estabelecimento de algumas hipōteses, basea das no conhecimento da composição mineralógica da misturá, para poder deduzir a förmula quîmica dos minerais. 
TABELA 12

COMPOSIÇAO QUTMICA (E EM PESO) E FORAULA ESTRUTURAL DOS MINERAIS HIPUGENOS

\begin{tabular}{|c|c|c|c|c|c|c|c|c|c|c|c|c|c|c|}
\hline & $\mathrm{H}_{2} \mathrm{O}^{+}$ & $\mathrm{SiO}_{2}$ & $\mathrm{MSO}_{5}$ & $\mathrm{FeO}$ & $\mathrm{Fe}_{2} \mathrm{O}_{3}$ & $A_{i}{ }_{2} C_{3}$ & $\mathrm{Cr}_{2} \mathrm{O}_{3}$ & NiO & 000 & CuO & $\mathrm{MnO}_{2}$ & $\mathrm{CaO}$ & $\mathrm{TiO}_{2}$ & Total \\
\hline Oivina & 0 & 40,50 & 45,12 & 10,71 & - & 0,24 & 0,03 & 0,35 & - & - & 0,27 & 0,32 & 0,01 & 97,55 \\
\hline Piroxēnio & 0 & 51,69 & 15,45 & 5,24 & - & 1,85 & 0,05 & 0,06 & - & - & 0.03 & 23,12 & 1,47 & 98,95 \\
\hline Serpentina & 14,0 & 40,8 & 36.5 & 6,40 & - & 0,00 & 0,06 & 0,27 & 0,01 & 0,010 & 0,07 & 0,08 & - & 98,20 \\
\hline $\begin{array}{l}\text { Vermicutita } \\
\text { (en veios) }\end{array}$ & 16,0 & 35,70 & 30,85 & - & 7,8 & 10,40 & 0,04 & 0,08 & 0,01 & 0,025 & 0,04 & 1,00 & - & 101,95 \\
\hline
\end{tabular}

\begin{tabular}{|c|c|}
\hline Oivina & 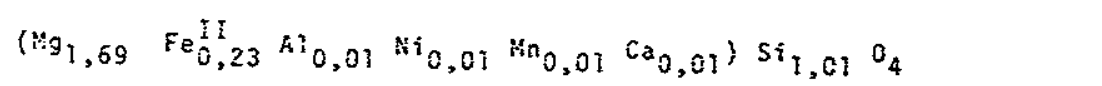 \\
\hline Piroxērio & $\left(\mathrm{M}_{\mathrm{S}_{0,43}} \mathrm{Fe}_{0,08}^{\mathrm{II}} \mathrm{Ca}_{0,45}{ }^{\mathrm{II}} \mathrm{i}_{0,02}\right)\left(S \mathrm{Si}_{0,96} \mathrm{AI} \mathrm{I}_{0,04}\right) \mathrm{O}_{3}$ \\
\hline Veraic & 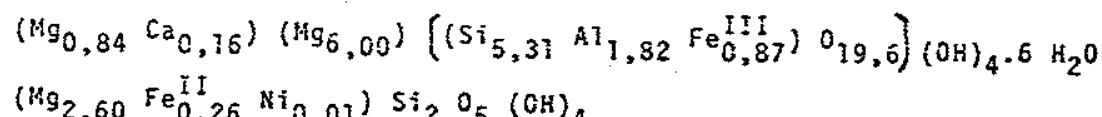 \\
\hline
\end{tabular}


Foram analisadas amostras contendo as seguin tes associações: kerolita e serpentina (amostra 54-br), quartzo, kerolita e serpentina (amostra Gl04-br), carbona tos, kerolita e serpentina (amostra XXVII-17), dolomita e serpentina (amostra $A 1-b r$ ), pimelita e serpentina (amostra 107-ve) e quartzo e pimelita (amostra Al-ve). A vermiculita niqueliffera corresponde às amostras $G$ veio, $105 \mathrm{~B}$ e 106, coletadas de veios de um material fino e esverdeado que cortam a rocha mais ou menos alterada, no perfil do poço $G$. Tra ta-se de vermiculita de granulação fina, um pouco evoluĩda e com teores de $\mathrm{NiO}$ da ordem de $3,5 \%$. A tabela 13 apresenta a composição química das amostras acima mencionadas.

Parece provāvel que o Ni das vermiculitas não pertence ao retĩculo cristalino, mas se encontra, talvez,precipitado como $\mathrm{Ni}(\mathrm{OH})_{2}$ nas microfissuras deste mineral. Esta hipötese serā testada pelo mëtodo dos ataques quĩ micos parciais, como exposto adiante.

Na pimelita, O $\mathrm{Ni}$ deve ocupar os sitios do $\mathrm{Mg}$ no reticulo, como efeito de semelhança de carga e de raio iônico. Assim como no caso das vermiculitas, a sustentação desta hipötese serā fornecida pelo mētodo dos ataques quĩmi cos parciais.

As razöes moleculares $\mathrm{SiO}_{2}$ sol/MgO+NiO, calculadas para algumas misturas, mostram que as amostras $54-b r$ e G104-br são compostas por kerolita e serpentina em quanti dades aproximadamente iguais, sendo que na primeira,predom na ligeiramente a serpentina,e,na segunda, a kerolita. A amostra AT-ve é composta de uma mistura de quartzo, calcedônia e pimelita. Atribuindo todo o $\mathrm{Ni}$ e Mg a este ültimo mineral, é possível calcular a quantidade de sĩlica correspon dente e sua förmula estrutural:

$$
\left(\mathrm{Mg} 1,86^{\mathrm{Ni}}{ }_{1,14}\right)\left(\mathrm{Si}_{3,83^{\mathrm{Al}}}, 066_{0,11}^{\mathrm{Fe}}\right)^{\mathrm{III}} \mathrm{O}_{10}(\mathrm{OH})_{2} \mathrm{H}_{2} \mathrm{O}
$$


TABELA 13

COMPOSIÇAO QUTMICA (\% PESO) E RAZOES MOLECULARES DOS PRODUTOS DA ALTERACÇAO

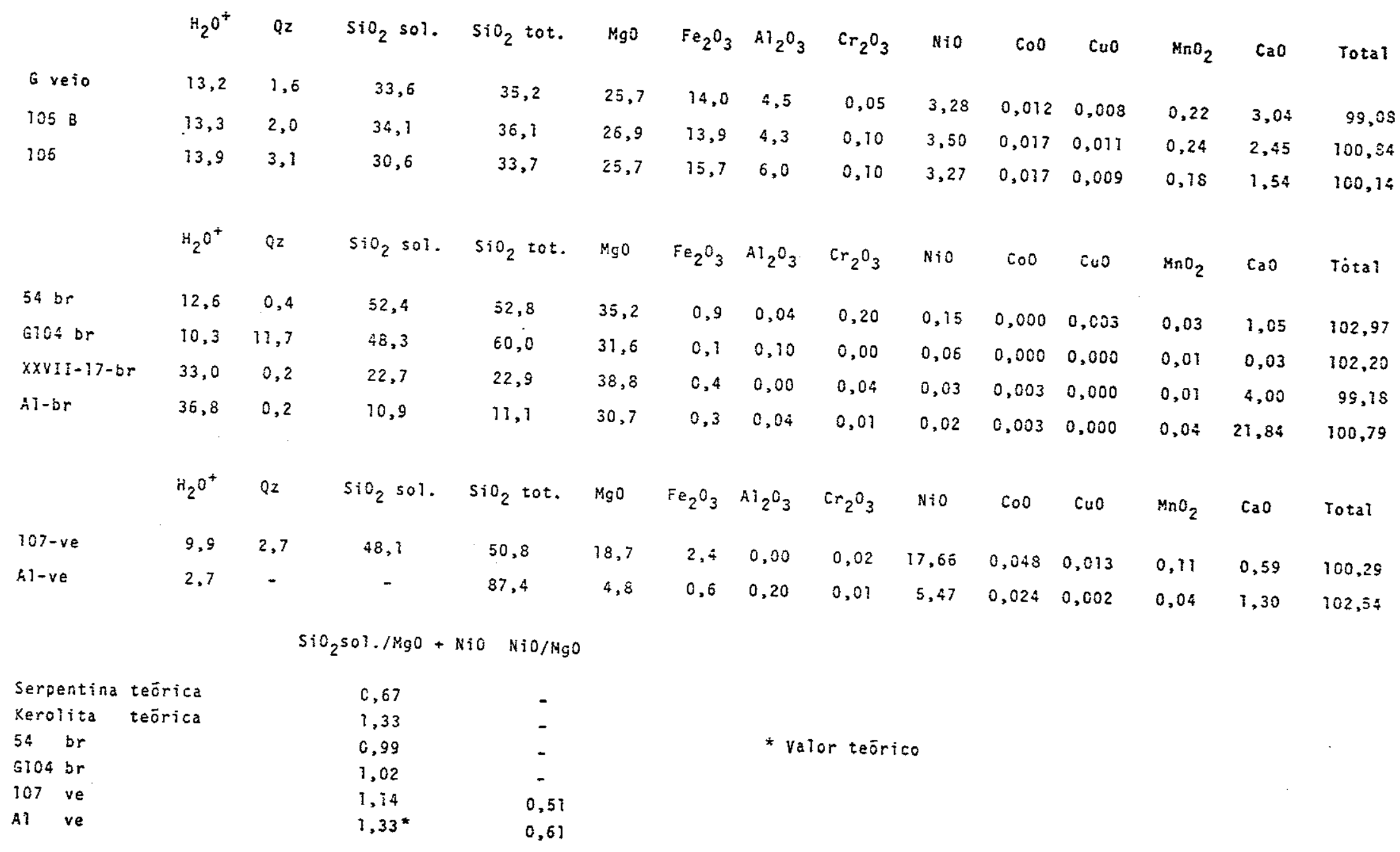


Assim, a pimelita pura conteria cerca de $20 \%$ em peso de $\mathrm{NiO}$ e apresentaria uma razão molecular $\mathrm{NiO} / \mathrm{Mg} 0=$ 0,61. O fato de a amostra 10.7-ve conter $17,7 \%$ de NiO e NiO/ $\mathrm{MgO}=0,51$ vem corroborar a hipötese, levantada quando do tra tamento da evolução mineralögica, segundo a qual o silicato niquelifero seria apenas a pimelita neoformada, sendo a ser pentina dos veios herdada da fase hipógena,e pouco enrique cida de $\mathrm{Ni}$.

\section{a.2.2.2. Ataques quimicos parciais}

Os ataques quimicos parciais para extração de amorfos segundo o mëtodo Segalen 1968 (Apēndice II) fornecem não sō a proporção de amorfos, mas sua composição. A maior ou menor cristalinidade das espēcies minerais ē refle tida na maior ou menor linearidade de suas curvas de disso1 ução. Assim, este mëtodo serā empregado com a finalidade de fornecer melhores subsidios ao conhecimento do modo de inserção dos elementos no retĩculo cristalino.

As amostras $A 1-v e$ e 107-ve revelam curvas de dissolução do $\mathrm{Mg}$ e $\mathrm{Ni}$ sensivelmente pröximas de uma reta (figura 30), o que indica que praticamente a totalidade des tes elementos encontra-se no retīculo cristalino da pimelita. Tão somente cerca de $4 \%$ do NiO contido em ambas as amos tras teria uma lixiviação mais räpida, correspondendo, talvez, a material adsorvido. A semelhança das curvas para ambas as amostras é outra indicação de que o mineral de $\mathrm{Ni}$ neo formado da amostra 107-ve, a exemplo da amostra Al-ve, e pimelita.

As amostras 105B e 106 (figura 31), compostas por vermiculita niqueliffera, apresentam curvas de disso lução com características interessantes: Fe e Mg dissolvemse linearmente e o $\mathrm{Ni}$ dissolve-se irregularmente. Este comportamento vem corroborar a hipōtese de que a vermiculita $\overline{\mathrm{e}}$ 
$\%$ NiQ, MgO extraido em reloçōo ao $\mathrm{NiO}, \mathrm{MgO}$ to tal

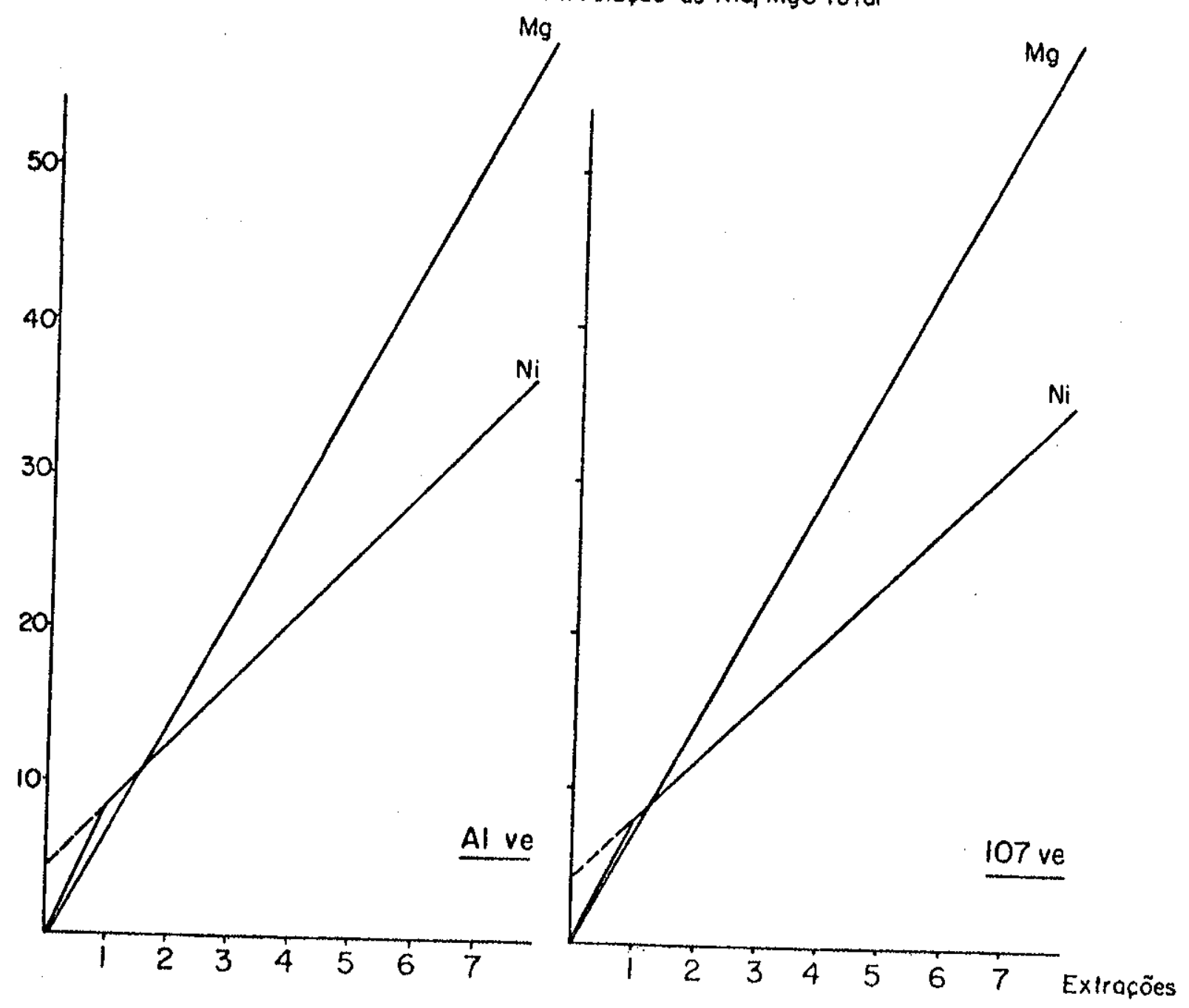

Fig.30 - Curvas de extracăo - Método Segalen - Minerais de Ni 
$\% \mathrm{NiO}, \mathrm{MgO}$ extroido em reloçõo ao $\mathrm{NiO}, \mathrm{MgO}_{9}$ total

$\% \mathrm{Fe}_{2} \mathrm{O}_{3}$ extroido em reloção oo $\mathrm{Fe}_{2} \mathrm{O}_{3}$ total

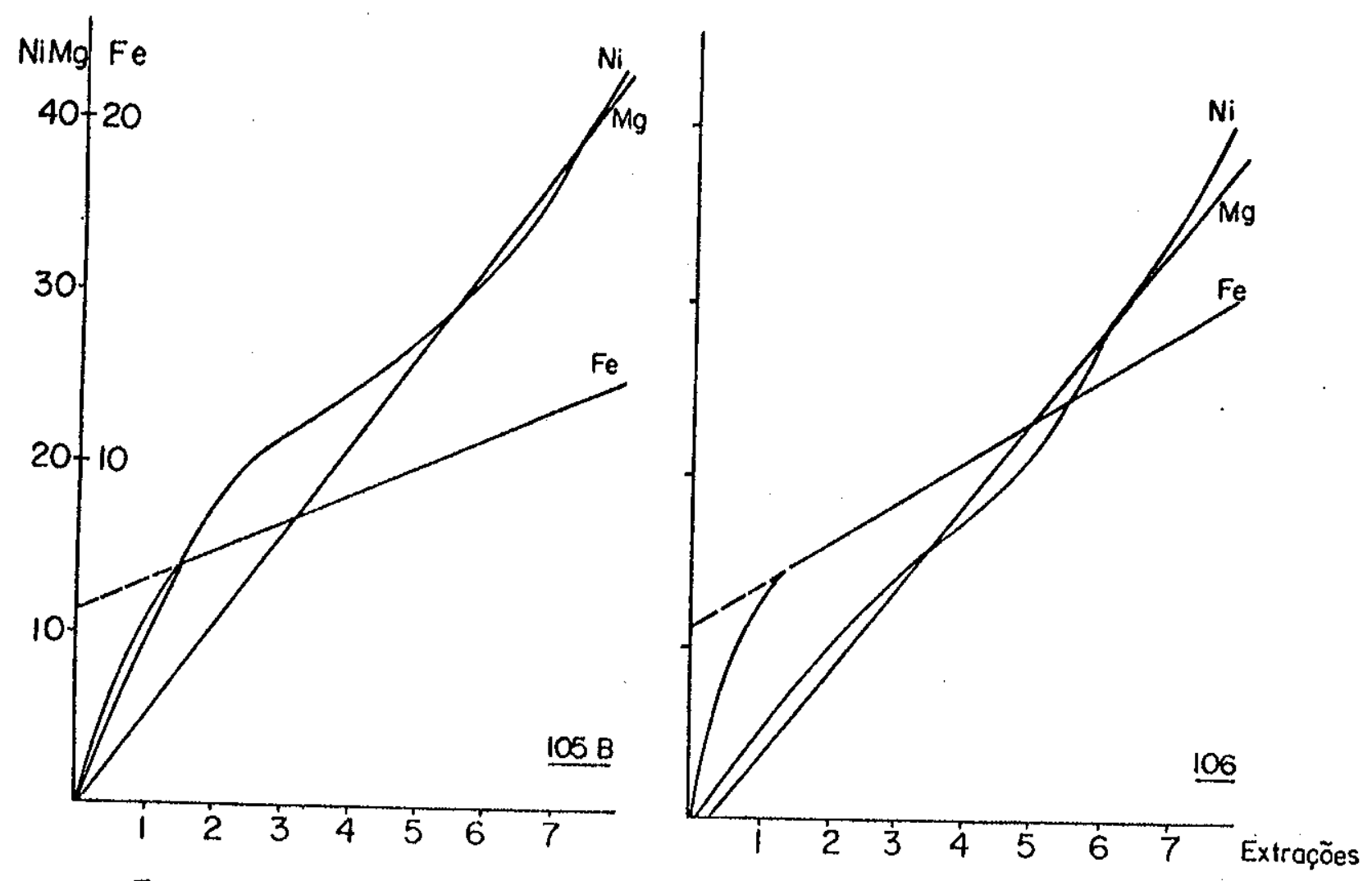

Fig 31-Curvas de extração - Método Segalen - Vermiculifas niqueliferas 
uma fase bem cristalizada; ē tambēm evidēncia de que o $\mathrm{Ni}$, talvez sob forma de $\mathrm{Ni}(\mathrm{OH})_{2}$, mais bem cristalizado no caso da amostra 106, menos bem cristalizado na amostra 105B, não faça parte do retīculo dos silicatos, mas se encontre adsor vido aos cristais, ou em suas fissuras. A curva do Fe, ao contrārio da do $\mathrm{Mg}$, não passa pela origem, e isto pode ser interpretado como uma dissolução inicial do Fe amorfo, produto do estado de alteração incipiente da vermiculita.

O mëtodo de extração de amorfos foi usado ainda para fornecer informações importantes a respeito do comportamento do $\mathrm{Fe}$ e do $\mathrm{Ni}$ em estāgios intermediārios da a 1 teração (figuras 32 e 33 ). Com este fim, foram analisadas as amostras 123,124 e 125 , que representam uma transição de $S G$ a LV, sem chegar propriamente a esses extremos. A amostra 123 é um saprolito grosseiro bem alterado, jā com alguma goethita; a 124 ē LA típica, enquanto a 125 é uma transi ção para LV, evidenciando alto teor em Fe e início de concrecionamento (vide Apêndice I). A amostra 109 lat represen ta uma LV pouco evoluida e rica em $\mathrm{Ni}$.

A tabela 14 mostra a proporção dos óxidos a-
morfos sobre sua quantidade total na amostra, calculada partir das figuras 32 e 33 .

A diminuição de $\mathrm{Fe}$ amorfo e mal cristalizado em direção às amostras mais alteradas confirma a hipōtese a diantada anteriormente: a 01 ivina e a serpentina alteram-se, deixando, no inïcio, um resíduo ferruginoso amorfo, que pas sa gradativamente a goethita. $0 \mathrm{Mg}$ è evacuado na medida em que ē liberado dos silicatos primārios: a extração linear significa a existencia de Mg apenas no reticulo cristalino. o Ni parece acompanhar o comportamento do Fe, concentrandose inicialmente como compostos mal cristalizados e incorporando-se, em seguida, ao retículo da goethita. 
$\% \mathrm{NiO}, \mathrm{MgO}, \mathrm{Fe}_{2} \mathrm{O}_{3}$ extraido em relação oo $\mathrm{NiO}, \mathrm{MgO}, \mathrm{Fe}_{2} \mathrm{O}_{3}$ tolal.

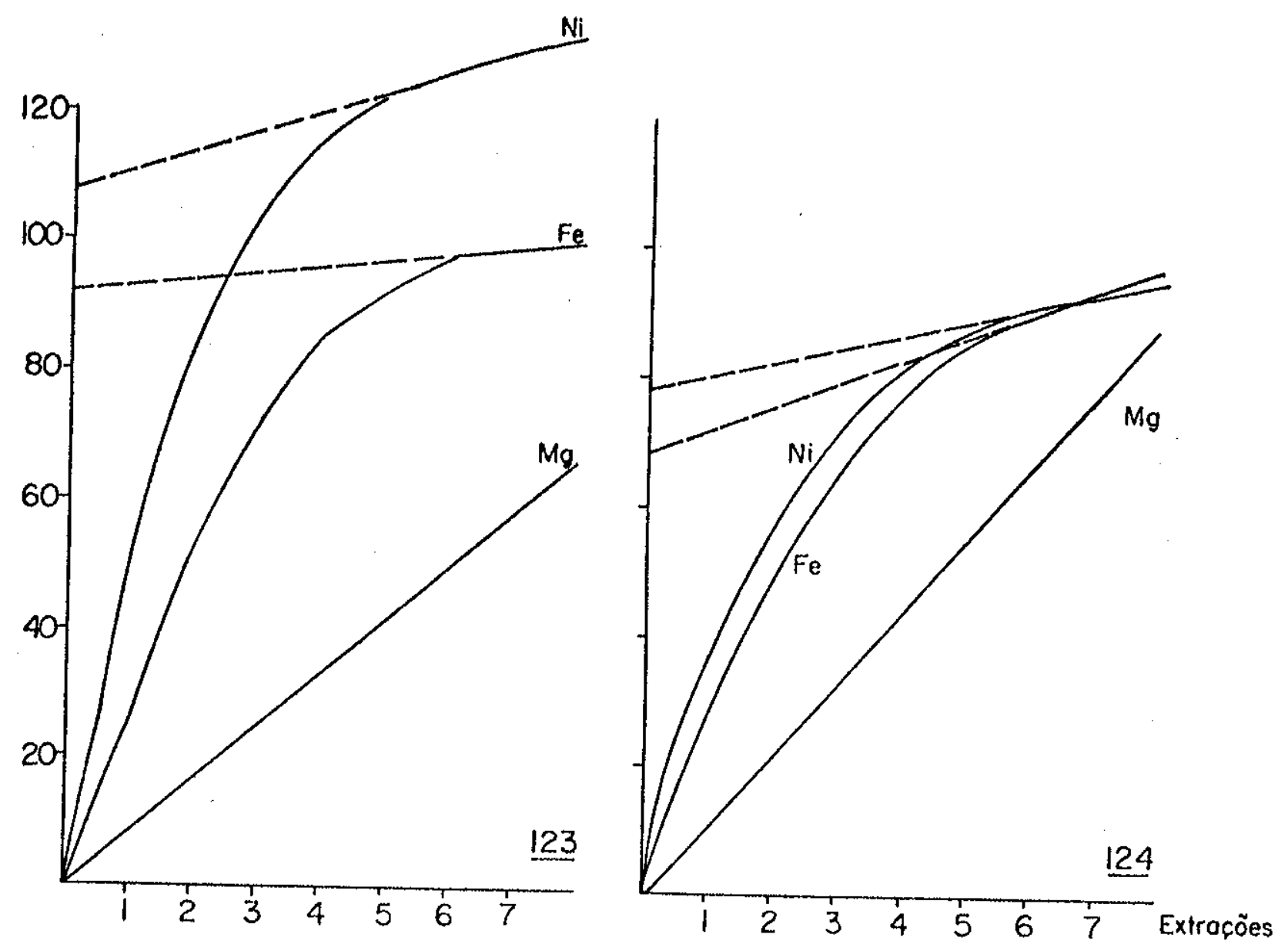

Fig32-Curvas de extração - Método Segalen - SG e LA 
$\% \mathrm{NiO}, \mathrm{MgO}, \mathrm{Fe}_{2} \mathrm{O}_{3}$ extraido em relaçöo ao $\mathrm{NiO}, \mathrm{MgO}, \mathrm{Fe}_{2} \mathrm{O}_{3}$ totol.
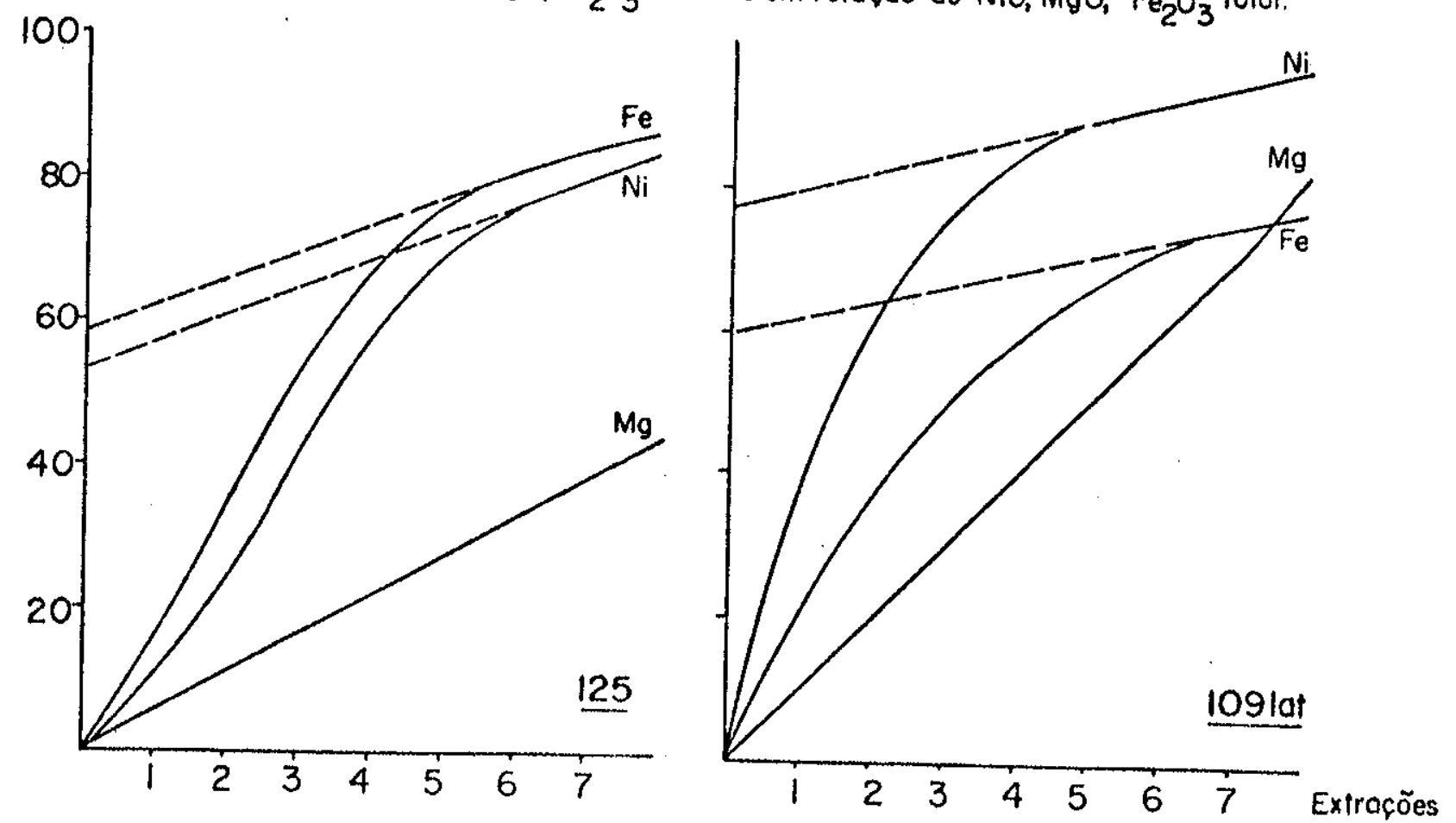

Fig 33-Curvas de extração - Método Segalen - Lateritas Vermethas 


\section{TABELA 14}

PROPORÇAO DOS OXIDOS AMORFOS E MAL CRISTALIZADOS EM RELAÇAO A SUA QUANTIDADE TOTAL NA AMOSTRA

$\begin{array}{lcc} & \mathrm{Fe}_{2} \mathrm{O}_{3} & \mathrm{NiO} \\ 123 & 92 \% & 108 \% * \\ 124 & 68 \% & 78 \% \\ 125 & 62 \% & 57 \% \\ 109 \text { lat } & 60 \% & 77 \%\end{array}$

* Este valor de $108 \%$ resulta do fato de a anälise total da amostra ter indicado um teor em NiO menor que a quantida de extraída pelo mëtodo Segalen. Isto pode ser atribuido à grande heterogeneidade do material, mas não invalida as conclusões. 
a.2.2.3. Anälise das frações granulomētricas

A anälise das frações granulomētricas fornece, indiretamente, informações sobre a composição quĩmica dos constituintes mineralögicos. No inīcio da alteração, os minerais mais resistentes acumulammse nas frações grosseiras, e os produtos neoformados ficam nas frações mais finas. Em estāgios mais avançados, com o concrecionamento, mate riais de origem supërgena podem acumular-se nas frações mais grosseiras.

Para o estudo quĩmico de 3 frações granulometricas $(A-\phi>0,25 \mathrm{~mm} ; B-0,062 \mathrm{~mm}<\phi<0,25 \mathrm{~mm} ; C-\phi<0,062 \mathrm{~mm})$, foram escolhidas as amostras 121, 122, 123, 124, 127, representativas de 5 estägios da alteração. Suas composições quïmicas e granulomëtricas constam da tabela 15; a granulometria encontra-se tambëm representada na figura 6 .

A amostra $121 \vec{e}$ de rocha dura, apresentando sinais incipientes de alteração, somente discerniveis ao mi croscōpio. A amostra 122 de rocha pouco alterada $\bar{e}$ constituĩda, em sua maior parte, por fração grosseira. Esta apresenta composição quĩmica semelhante à amostra 121, bem como as frações $B$ e $C$, o que indica que a alteração começa principalmente por simples desagregação mecānica do reticulado de serpentina e olivina. O conteūdo em $N i$ jā $\bar{e}$ um pouco mais elevado do que na rocha fresca, principalmente na fração C. 0 SG, representado pela amostra $123, \vec{e}$ bastante evoluĩdo. A fração mais grosseira, representando apenas $10 \%$ da amostra, ainda tem composição quỉmica semelhante às amostras 121 e 122, apresentando, porëm, significativa perda em $\mathrm{MgO}$ e ganho em $\mathrm{Fe}_{2} \mathrm{O}_{3}$, o que deve corresponder à dissolução da olivina. Estes aspectos acentuam-se nas frações $B$ e $C$, sendo esta ültima de composição bem ferruginosa, embora ain da conserve serpentina, como indica o teor de $17,8 \%$ de $\mathrm{Mgo}$. $0 \mathrm{Ni}$ mostra-se fortemente concentrado em relação à rocha fresca nas 3 frações granulometricas, especialmente na fra- 
TAEELA 15

ANALISE QUTMICA DAS FRAÇOES GRANULOMETRICAS ( $\%$ EM PESO)

\begin{tabular}{|c|c|c|c|c|c|c|c|c|c|c|c|c|c|c|c|}
\hline & & $\mathrm{H}_{2} \mathrm{O}+$ & $\mathrm{Qz}$ & $\mathrm{SiO}_{2} \mathrm{50}$ & $\mathrm{MgO}$ & $\mathrm{Fe}_{2} \mathrm{O}_{3}$ & $\mathrm{Al}_{2} \mathrm{O}_{3}$ & $\mathrm{Cr}_{2} \mathrm{O}_{3}$ & NiO & CoO & CuO & $\mathrm{MnO}_{2}$ & $\mathrm{CaO}$ & Total & $\frac{\mathrm{CON}_{2}}{\mathrm{COO}}$ \\
\hline 1212 & $(100)^{*}$ & 12,3 & 0,2 & 37,5 & 37,3 & 13,2 & 0,2 & 0,26 & 0,27 & 0,017 & 0,011 & 0,36 & 0,35 & 101,7 & 9,4 \\
\hline $122 \mathrm{~A}$ & $(70)$ & 12,0 & 1,2 & 36,8 & 34,5 & 16,5 & 0,2 & 0,58 & 0,45 & 0,024 & 0,003 & 0,21 & 0,10 & 102,6 & $s, s$ \\
\hline $122 B$ & $(10)$ & 11,8 & 1,4 & 39,0 & 31,6 & 15,0 & 1,2 & 7,62 & 0,60 & 0.029 & 0,003 & 0,22 & 0,35 & 102,8 & 7,6 \\
\hline $122 c$ & $(20)$ & 13,1 & 1,5 & 38,3 & 30,7 & 15,8 & 0,8 & 0,52 & 0,69 & 0.058 & 0,025 & 0,42 & 0,45 & 102,4 & 7,2 \\
\hline$i 23 \hat{A}$ & $(10)$ & 12,3 & 3,0 & 34,0 & 24,6 & 22,9 & 0,3 & $0,3\}$ & 1,78 & 0,038 & 0,004 & 0,29 & 0,07 & 100,1 & 7,6 \\
\hline 1238 & $(15)$ & 8,2 & 3,3 & 23,2 & 20,0 & 34,8 & $i, 1$ & 9,48 & 1,44 & 0,041 & 0,011 & 0,34 & 0,07 & 101,9 & $s, 3$ \\
\hline 1236 & $(74)$ & 13,6 & 0,9 & 22,9 & 17,8 & 43,0 & 0,3 & 0,46 & 2,57 & 0,081 & 0,053 & 0,60 & $0,5 \bar{c}$ & 101,9 & 7,4 \\
\hline$i 2 \% A$ & (3) & 10,5 & 14,8 & $2 \varepsilon, 6$ & 20,8 & 23,3 & 0,4 & 1,32 & 2,39 & 0,029 & 0,006 & 0,27 & $0,: 3$ & 100,5 & 9,3 \\
\hline$: 248$ & (9) & 1.6 & \multicolumn{2}{|c|}{$-15,44-$} & 6.0 & 57,9 & 2,0 & 23,54 & 1,25 & 0.076 & 0,004 & 0.59 & 0,04 & 102,4 & 7,5 \\
\hline $124 C$ & $\{88\}$ & 11,1 & 5,3 & 12,5 & 6,6 & 56,5 & 0,8 & 0.92 & 3,37 & 0,076 & 0,086 & 0,52 & - & 97.8 & 6,9 \\
\hline $127 \AA$ & $(10)$ & 4,3 & 7,3 & 4,3 & 1,0 & 63,0 & 5,8 & 7,02 & 0,80 & 0,239 & 0,012 & 1,19 & 4,45 & 99,4 & 5,0 \\
\hline 1278 & $(44)$ & 2,1 & 8,4 & 0,4 & 1,6 & 75,3 & 3,6 & 6,09 & 0,79 & 0,720 & 0,008 & 0,63 & - & 99,0 & 5,3 \\
\hline $127 c$ & $(46)$ & 3,1 & 8,7 & 2,3 & 1,7 & 74.5 & 3,3 & 6.31 & 0,72 & 0,068 & 0,036 & 0,35 & - & 101,1 & 5,1 \\
\hline
\end{tabular}

* Os nümeros entre parēnteses correspondem à porcentagem da fração granulamētrica considerada 
ção mais fina.

A medida que a alteração prossegue (124), a fração grosseira diminui em quantidade, porēm conserva composição quĩmica que reflete conteüdo ainda rico em serpenti na. A fração B e, em maior grau, a fração $C, j \bar{a}$ mostram com posição predominantemente ferruginosa. Os valores de são elevados, principalmente nas frações $A$ e $C$.

No horfzonte de LV, o concrecionamento è evidente: a fração $B$ e sobretudo a fração A tornam-se mais abundantes. São todas elas predominantemente ferruginosas; quase totalmente desprovidas de $\mathrm{MgO}$ e bastante desidratadas. E o estägio correspondente à passagem goethita-hematita,mar cado por empobrecimento em $\mathrm{NiO}$.

o comportamento dos elementos menores fica muito bem evidenciado atravēs da anälise quimica das frações granulomëtricas. $\mathrm{O} \mathrm{Al}_{2} \mathrm{O}_{3}$ e $\mathrm{O}_{\mathrm{Cr}_{2} \mathrm{O}_{3}}$ apresentam evolução semelhante, concentrando-se, desde o inĩcio da alteração, na fração $B$, que representa o tamanho dos grãos de cromita e vermiculita. Com o concrecionamento, ambos passam a predomi nar na fração A. A presença significativa desses 2 elementos nas frações $C$ das amostras 124 e 127 indica que eles de vem tambëm estar associados à goethita. O Co e Mn tambëm têm comportamento correlacionāvel: sofrem, de modo geral, concentração, sendo que, nos primeiros estägios (122 e 123), mostram mais altos teores na fração $C$. Na LA, começa um deslocamento do enriquecimento para as frações mais grosseiras e, finalmente, na $L V$, encontram-se principalmente na fração A, o que reflete o concrecionamento dos öxidos de $\mathrm{Mn}$ e Co. As razões $\mathrm{MnO}_{2} / \mathrm{CoO}, \mathrm{calculadas}$ para as värias frações granulomētricas das vārias amostras,apresentam-se em torno do valor 8 para a RD, SG e SF, caindo para cerca de 5 na LV.IS so indica que nos estägios finais de alteração parece haver perda de $M n$ em relação ao $C_{0}$, o que jă havia sido constatado pela anälise da tabela 8 . 0 fato de as razóes serem mais. 
ou menos constantes para as frações granulomëtricas de cada amostra ē uma evidência de que estes elementos encontram-se estreitamente associados (Schellmann 1978). O Cu, de inserção mineralögica incerta, concentra-se sempre nas frações mais finas.

Resumindo, o resultado do estudo químico das frações granulomētricas dä suporte às seguintes hipōte ses:

- no inicio da alteração predomina a desagregação mecânica, mas o incipiente ataque quỉmico jā leva a um ligeiro enriquecimento em $\mathrm{Ni}$;

- segue-se a destruição da olivina e, mais tarde, a da serpentina; O Ni concentra-se como hidrōxido mais ou menos cristalizado associado à serpentina em vias de alteração,e incorpora-se à goethita à medida de sua for mação;

- nos estāgios mais evoluĩdos, com a passagem, por desidratação, da goethita a hematita, e com o con crecionamento, há eliminação parcial de $\mathrm{Ni}$;

- na rocha fresca, o Al e o Cr predominam, respectivamente, na vermiculita e na cromita; com a altera ção, passam, parcialmente, a integrar o retículo da goethi ta;

- o Co e o Mn associam-se em concreções de tamanho crescente em direção aos horizontes mais evoluĩdos.

b. A evolução das rochas portadoras de piroxênio b.1. Perfis sobre peridotito: Pe e S10W4 
Na tabela 16 estä indicada a composição qui mica de amostras de 2 perfis de alteração sobre peridotito. 0 perfil slow4 corresponde a um peridotito que contēm menos piroxēnio que o peridotito do perfil Pe.

Nesta rocha, o comportamento dos elementos quĩmicos durante a alteração è essencialmente o mesmo que nos dunitos: perda de sĩlica e magnësia e enriquecimento em $\mathrm{Fe}_{2} \mathrm{O}_{3}, \mathrm{Al}_{2} \mathrm{O}_{3}, \mathrm{Cr}_{2} \mathrm{O}_{3}, \mathrm{COO}$ e $\mathrm{MnO}_{2} \cdot 0 \mathrm{CaO}$, presente nestas rochas em quantidade tanto maior quanto major o teor em pi roxēnio, comporta-se como o Mgo, sofrendo diminuição nos horizontes mais alterados.

A perda do $\mathrm{CaO}$, mais räpida que a do Mgo,re flete a precoce dissolução do piroxênio com relação à serpentina. Ambos os ōxidos são evacuados à medida de sua liberação. A $\mathrm{SiO}_{2}$ fica, em parte, inicialmente retida como material amorfo, ou no retīculo das esmectitas ferriferas, derivadas da alteração dos piroxēnios. Pode tambëm acumuTar-se na base do perfil sob forma de veios de quartzo. 0 Fe, liberado tambēm quando da alteração dos silicatos hipọ genos, ē fixado,seja como amorfo, juntamente com a silica, seja como elemento integrante da nontronita. A posterior dessilicificação dos amorfos leva à cristalização do Fe em goethita e finalmente em hematita. Reflexo de todo esse processo ē a variação do teor em $\mathrm{H}_{2} \mathrm{O}^{+}$nos diferentes fäcies de alteração:aumento no saprolito fino (formação de goethi ta) e diminuição na laterita vermelha (formação de hematita).

O teor de NiO è tanto maior quanto menor for a porcentagem de piroxēnio no peridotito, jä que este elemento estä inicialmente situado principalmente na oli vina (tabela 12). Com a alteração, concentra-se no horizon te de saprolito grosso e principalmente no saprolito fino, sofrendo perda na laterita vermelha. E essencialmente o - mesmo processo que ocorre nos dunitos, mas em menor escala. 
TABELA 16

COMPOSIÇAO QUYMICA DOS FACIES DE ALTERAÇAO SOBRE PERIDOTITO (\% PESO)

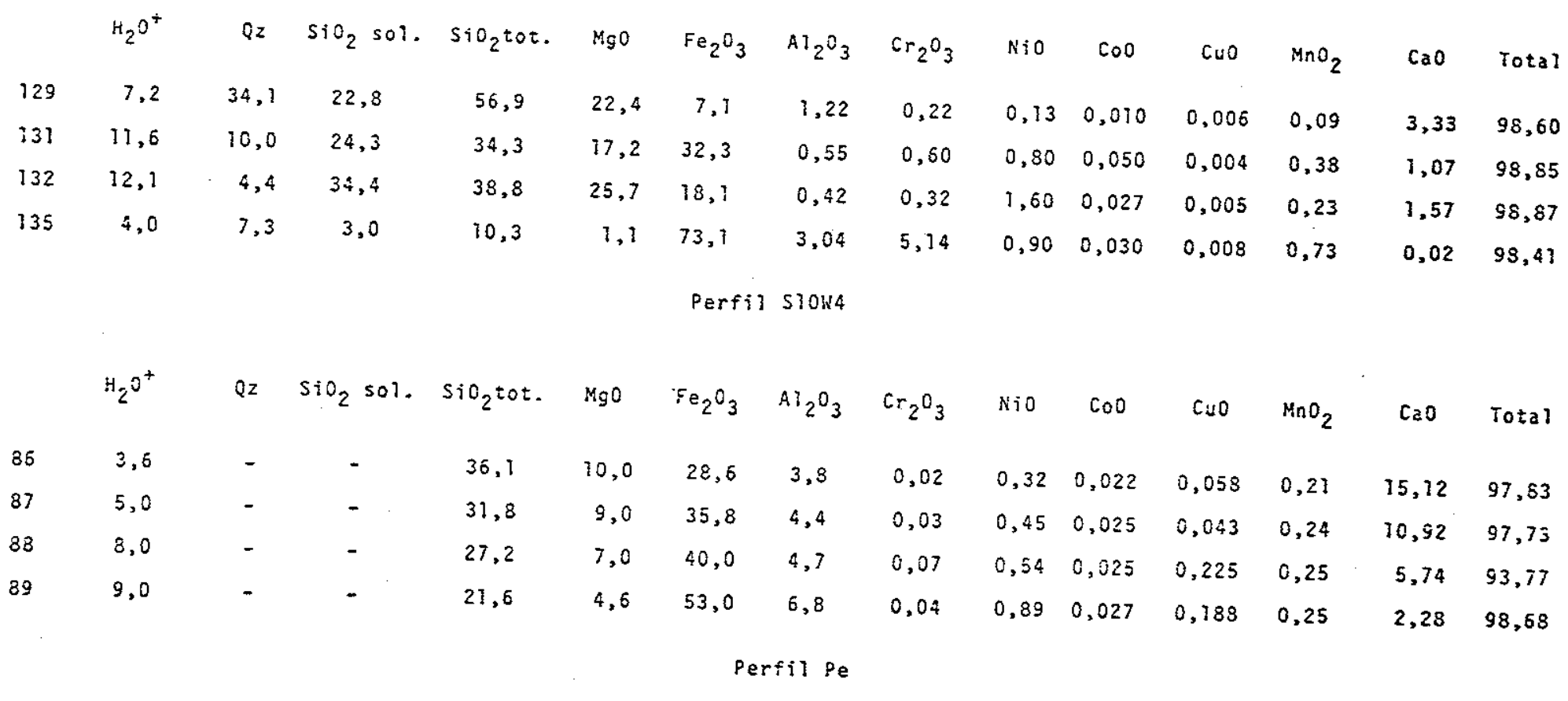




\section{b.2. Perfil sobre piroxenito: Py}

Embora chegando a $10 \mathrm{~m}$ de profundidade, o per fil Py não alcança a rocha, terminando num material saproli tico jă bem alterado. As amostras 93, 95, 97 correspondem a um saprolito verde que se torna amarelado (98) e passa para saprolito amarelo na amostra 99. As amostras 100 e 102 são lateritas vermelhas que apresentam sinais de ter sofrido al gum transporte.

Comparando os dados da tabela 17 coma anälise quimica da rocha fresca (tabela 2), percebe-se que, nos estāgios de alteração representados pelas amostras 93,95 e 97, hă uma certa perda relativa de $\mathrm{SiO}_{2}, \mathrm{MgO}$ e CaO, e aumento em $\mathrm{Fe}_{2} \mathrm{O}_{3}, \mathrm{Al}_{2} \mathrm{O}_{3}, \mathrm{Cr}_{2} \mathrm{O}_{3}$ e $\mathrm{CoO}$. Nas amostras 98 e $99, j \bar{a}$ mais evoluidas, este comportamento $\bar{e}$ ligeiramente acentuado,prin cipalmente no que diz respeito ao $\mathrm{Fe}$.

0 CuO e $\mathrm{OnnO}_{2}$ não apresentam comportamento sistemātico.A quantidade de $\mathrm{H}_{2} \mathrm{O}^{+} \overline{\mathrm{e}}$ variāvel no saprolito, mantendo-se ao redor de $10 \%$, e cai à metade na LV.

Nas amostras de saprolito verde, a composição quỉmica reflete a neoformação de nontronita (concentração de $S i$, Fe e um pouco de $A T$ e $M g$ ) e a concentração res $i$ dual de "mica". A anälise quimica destes minerais consta da
tabela 17 .

o saprolito amarelo representa uma transição, no sentido de destruição do silicato secundārio, eliminação de $\mathrm{SiO}_{2}$ e $\mathrm{MgO}$ e concentração de Fe (goethita e hematita) e do Al (boehmita). 0 alto teor de $\mathrm{SiO}_{2}$ das amostras 100 e 102 é atribuido ao quartzo de origem coluvionar.

$0 \mathrm{NiO}$, presente na rocha fresca em pequena quantidade $(0,06 \%)$, sofre ligeiro enriquecimento, mas não atinge valores interessantes economicamente. Seu processo. 
TABELA IT

COMPOSIÇAO QUIHICA DE AMOSTRAS PROVENIENTES DO PERFIL PY (\% EM PESO)

\begin{tabular}{|c|c|c|c|c|c|c|c|c|c|c|c|}
\hline & $\mathrm{H}_{2} \mathrm{O}^{+}$ & $\mathrm{SiO}_{2}$ tot & $\mathrm{HgO}$ & $\mathrm{Fe}_{2} \mathrm{O}_{3}$ & $\mathrm{Ai}_{2} \mathrm{O}_{3}$ & $\mathrm{Cr}_{2} \mathrm{O}_{3}$ & Nio & 600 & CuO & $\mathrm{MnO}_{2}$ & $\mathrm{CaO}$ \\
\hline 93 & 14,7 & 45,8 & 11,8 & 17,9 & 6,8 & 0,12 & 0,14 & 0,015 & 0,011 & 0,17 & 2,80 \\
\hline 95 & 9,5 & 47,7 & 13,8 & $14, i$ & 4,3 & 0,09 & 0,06 & 0,008 & 0,070 & 0,08 & 7,28 \\
\hline 97 & 4,9 & 45,5 & 14,8 & 13,3 & 4,3 & 0,23 & $c, 09$ & 0,019 & 0,008 & 0,17 & 13,56 \\
\hline 98 & 10,7 & 46,9 & 12,9 & 17,2 & 5,3 & 0,20 & 0,10 & 0,017 & 0,005 & 0.16 & 8,12 \\
\hline 99 & 11,4 & 42,3 & 10,1 & 24,7 & 6,4 & 0,29 & 0,18 & 0,019 & 0,009 & 0,26 & 3,73 \\
\hline 120 & 4,7 & 59,5 & 0,60 & 29,3 & 5,3 & 0,65 & 0,32 & 0,030 & 0,010 & 0,14 & - \\
\hline \multirow[t]{8}{*}{102} & 6,3 & 35,9 & 0,99 & 40,1 & 10,9 & 1,45 & 0,38 & 0,035 & 0,019 & 0,22 & 0,15 \\
\hline & & $\mathrm{H}_{2} \mathrm{O}^{+}$ & $\mathrm{SiO}_{2}$ & $\mathrm{Al}_{2} \mathrm{O}_{3}$ & $\mathrm{Fe}_{2} \mathrm{O}_{3}$ & $\mathrm{TiO}_{2}$ & $\mathrm{CaO}$ & $\mathrm{MgO}$ & $\mathrm{Na}_{2} \mathrm{O}$ & $k_{2} 0$ & Total \\
\hline & 934 & 6,2 & 41,5 & 11,2 & 9,6 & 5,9 & 0,6 & $i 8,6$ & 0,2 & 3,5 & 99,4 \\
\hline & 95.4 & 6,4 & 42,2 & 11,9 & $n, I$ & 6,4 & 0,0 & 16,4 & 0,3 & 5,0 & 100,3 \\
\hline & S8M & 10,0 & 41,4 & 11,5 & 10,0 & $E, 7$ & 0,7 & 15,9 & 0,2 & 2,3 & 99,1 \\
\hline & s9ix & 13,0 & 35,8 & 11,1 & 11,1 & 5,6 & 0,5 & 16,9 & 0,9 & 4,3 & 99,2 \\
\hline & $100 \mathrm{M}$ & 8,7 & 38,9 & 34,6 & 11,9 & 7,1 & 0,3 & 13,5 & 0,2 & 4,0 & 99,2 \\
\hline & 955 & 15,2 & 54,2 & 3,2 & 19,3 & 1,8 & 0,3 & 4,5 & $0 ; 2$ & 0,1 & 98,8 \\
\hline
\end{tabular}

$93,95,98,99,100 \mathrm{M}$ - "Micas" separadas das amostras 93,95,98,99,100 (01iveira 5 Mel:i 1979) 
- de concentração pode estar ligado à precipitação da nontro nita e, mais provavelmente, à formação da goethita, jä que parece que seu teor cresce com o aumento de $\mathrm{Fe}_{2} \mathrm{O}_{3}$. A quantidade de NiO contida nas amostras 100 e 102 é de dificil interpretação, dado o caräter coluvionar deste material.

0 estudo de detalhe da evolução das "micas" contidas nos piroxenitos de Santa Fë (Oliveira $\xi$ Melfi 1978) mostrou que, apesar destes minerais serem bastante estāveis, apresentam, nos níveis mais alterados, leve dimi nuição de $\mathrm{Mg}$ e aumento em $\mathrm{Fe}$ (tabela 17). Este fato pode ser reflexo da incipiente transformação mica $\rightarrow$ esmectita, perceptivel apenas ao microscōpio eletrōnico.

c. Um perfil extremamente silicificado (Perfil C)

Trata-se de um perfil de alteração de $9 \mathrm{~m}$ de profundidade, intensamente silicificado, constituído por um reticulado de quartzo e calcedonia preenchido e envolvido por laterita avermelhada, que aumenta em quantidade em direção ao topo do perfil. Foram analisadas as amostras 111 , 114 e 118 , correspondendo respectivamente às profundidades de 9,6 e $2 \mathrm{~m}$, sendo que a amostra 114 foi analisada para 3 frações granulomëtricas (tabela $18 \mathrm{~A}$ ). Neste caso, foi dosada a sĩlica total, jă que o ataque perciörico-sódico não discriminaria a silica dos silicatos da sîlica contida no boxwork, cuja composição, alëm do quartzo, inclui uma certa quantidade de sîlica mal cristalizada (calcedonia). Esta passa em solução juntamente com a silica dos silicatos.

A anālise dos dados referentes às amostras 111 e 118 mostra que estas são constituĩdas, em sua maior parte, por um arcabouço silicoso, preenchido por material saprolitico jä bem laterizado. Assumindo-se, por aproximação, que toda a sĩiica seja quartzo ou calcedonia, resulta que, tanto a amostra 111 como a 118 são compostas, em sua 
TABELA IBA

COMPOSICAO QUTMICA DAS MMOSTRAS DO PERFIL C (\% EM PESO)

$\begin{array}{llllllllllll} & \mathrm{H}_{2} \mathrm{O}^{+} & \mathrm{SiO}_{2} & \mathrm{MgO} & \mathrm{Fe}_{2} \mathrm{O}_{3} & \mathrm{Al}_{2} \mathrm{O}_{3} & \mathrm{Cr}_{2} \mathrm{O}_{3} & \mathrm{NiO} & \mathrm{COO} & \mathrm{CHO} & \mathrm{MnO} 2 & \text { Total } \\ 111 & 5,1 & 56,4 & 0,7 & 34,7 & 1,6 & 1,23 & 0,73 & 0,081 & 0,009 & 0,38 & 100,9 \\ 118 & 2,4 & 78,6 & 0,3 & 15,3 & 0,5 & 0,66 & 0,29 & 0,025 & 0,004 & 0,15 & 98,2 \\ 114 \mathrm{~A} & 3,0 & 73,9 & 0,5 & 20,2 & 0,7 & 0,33 & 0,37 & 0,100 & 0,007 & 0,37 & 100,1 \\ 1148 & 6,1 & 43,4 & 1,0 & 41,7 & 3,6 & 2,38 & 0,78 & 0,050 & 0,046 & 0,26 & 99,3 \\ 114 C & 6,8 & 28,4 & 1,2 & 57,7 & 3,6 & 3,66 & 0,81 & 0,007 & 0,021 & 0,32 & 96,5\end{array}$

\section{TABELA 18B}

TEORES EM $\mathrm{Fe}_{2} \mathrm{O}_{3}$, MgO E NIO DA FRAÇAO LATERITICA DAS AMOSTRAS DO PERFIL C (\% EM PESO)

$\begin{array}{lccc} & \mathrm{Fe}_{2} \mathrm{O}_{3} & \mathrm{MgO} & \mathrm{NiO} \\ 111 & 79 & 1,6 & 1,6 \\ 118 & 72 & 1,4 & 1,4 \\ 114 \mathrm{~A} & 77 & 1,9 & 1,4 \\ 114 \mathrm{~B} & 74 & 1,8 & 1,4 \\ 114 \mathrm{C} & 72 & 1,7 & 1,1\end{array}$

TABELA $1 B C$

COMPOSICXO QUTMICA DA CROSTA FERRUGINOSA (\% EM PESO)

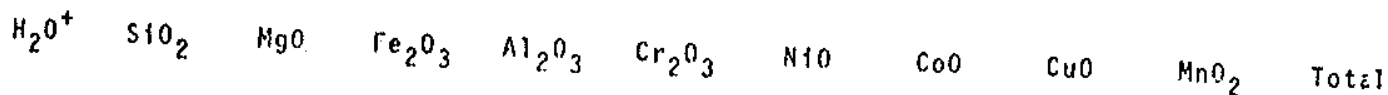
$\begin{array}{llllllllllll}B G 0-4 & 12,8 & 10,3 & 0,8 & 64,9 & 3,16 & 5,26 & 1,15 & 0,387 & 0,006 & 2,38 & 101,14\end{array}$ 
fração não silicosa, por mais de $70 \%$ de $\mathrm{Fe}_{2} \mathrm{O}_{3}$ e por quantidades muito subordinadas de Mgo, correspondentes à serpentj na remanescente. 0 teor em $\mathrm{NiO}$ nesta laterita $\overline{\mathrm{e}}$ de cerca de $1,5 \%$ (tabela 18B).

A anälise das frações granulomētricas confir ma a enorme quantidade de silica, concentrada principalmente na fração mais grosseira. 0 saprolito laterizado passa, em sua major parte, para a fração $C$. A concentração de Al e $\mathrm{Cr}$ nas fraçōes mais finas parece indicar que esses elementos não estariam mais, pelo menos parcialmente, associados à cromita, mas principalmente à goethita. Os teores de Mgo e $\mathrm{NiO}$ situam-se ao redor de $1,5 \%$, e o de $\mathrm{Fe}_{2} \mathrm{O}_{3}$ em mais de $70 \%$, no material laterizado das 3 frações granulomëtricas.

Devido ao aumento relativo de material silicoso nos niveis mais superficiais e ao fato de ser este material de granulação grosseira, as amostras mais evoluĩdas (118) têm composição semeinante ã da fração A de uma amostra menos evoluída. Em qualquer nivel, como em qualquer fra ção, a composição do saprolito laterizado é a mesma (tabela 18B). Daj̃ conclui-se que neste perfil a evolução se dä a partir de um serpentinito muito silicificado que sofre perda quimica de parte de seus componentes, resultando num arcabouço silicoso preenchido por saprolito laterizado. 0 material da parte superior do perfil e mais erodido, tendo es te processo tendido a esvaziar as cavidades do boxwork, car reando parte da laterita e deixando um arcabouço mais ou menos intacto.

d. Composição química da crosta ferruginosa

Foi analisado um fragmento de crosta ferrug $\underline{i}$ nosa (amostra BG0-4), encontrado pröximo a um eixo de drena gem, no sope da Serra do Tira-pressa. Os componentes minera lögicos principais desta amostra são goethita, hematita e 
quartzo. Sua composição quĩmica, constante da tabela 18C, as semelha-se à composição mëdia da LV (tabela 8) quanto aos teores em $\mathrm{SiO}_{2}, \mathrm{MgO}, \mathrm{Fe}_{2} \mathrm{O}_{3}, \mathrm{Al}_{2} \mathrm{O}_{3}, \mathrm{Cr}_{2} \mathrm{O}_{3}, \mathrm{CuO}$ e $\mathrm{NiO}$.

A crosta ferruginosa apresenta teor em $\mathrm{H}_{2} \mathrm{O}^{+}$ bem mais alto que a LV, indicando que ocorre hidratação durante o processo de concrecionamento.

Os altos valores de MnO e CoO na crosta ferruginosa parecem mostrar que estes elementos têm tendência de se concentrar nas concreções e no cimento que as solda.A razão $\mathrm{MnO}_{2} / \mathrm{CoO}=6,2$ vem, mais uma vez, indicar que, com 0 avanço da alteração, o enriquecimento em $M n \vec{e}$ relativamente menor que o enriquecimento em co.

e. Conclusões

o estudo químico realizado sobre as amostras representativas dos vārios estägios de alteração das rochas ultrabāsicas de Santa Fē permitiu definir o comportamento de cada elemento durante o processo superficial, aprofundan do, assim, a compreensão das filiaçōes mineralögicas.

os cälculos das mëdias de teores por horizon te, das correlações e das taxas de concentração evidenciaram o comportamento quantitativo de cada öxido e levaram ä distinção de 3 grupos de elementos, bem caracterizados:

- elemento möveis (Si, Mg e Ca), cujos teores vão decrescendo gradativamente atē o nĩvel de saprolito grosseiro para, a partir da $\bar{i}$, cair brutalmente;

- elementos residuais (Fe, Cr, Co, Cu, Al, Mn), cujos teores crescem à medida que a alteração prossegue; 
- Ni, que apresenta enriquecimento crescente ate o nível de laterita amarela, decrescendo nos horizon tes mais alterados.

As anālises químicas executadas sobre frações mineralögicas e granulomëtricas e a extração dos produtos mal cristalizados levaram ao detalhamento o estudo da repartição dos elementos entre os minerais (tabela 19), e possibilitou a discussão sobre seu modo de inserção no reticulo cristalino.

Durante a alteração dos dunitos serpentiniza dos, a contĩnua evacuação do $\mathrm{Si}$ e do $\mathrm{Mg}$, mais pronta deste e mais lenta daquele, reflete, num primeiromomento, a dis solução dos carbonatos e da brucita e, em seguida, dos silicatos hipōgenos. Acaba havendo eliminação praticamente total do $\mathrm{Mg}$ e parcial do $\mathrm{Si}$, que permanece, transitoriamen te, como constituinte dos compostos sílico-ferruginosos e, residualmente, sob forma de quartzo e calcedōnia. Os per fis de alteração situados nas baixadas, representantes de uma evolução mais ou menos atual (vide. Cap.I), indicam que este fenōmeno de retenção de parte da sīlica não $\bar{e}$ inten so, sendo relativamente pequena a quantidade de quartzo e calcedōnia que permanece. Não parece ter sido assim no pas sado, como indicam as amostras do poço $C$, no alto de um morrote, que devem representar a base de um antigo perfil. Aĭ a silicificação foi certamente muito mais intensa, resultando, apōs a laterização, num material composto por ate $80 \%$ de quartzo. Restos erodidos deste boxwork são encontrados nas baixadas.

Alëm da precipitação da sîtica sob forma de quartzo ou calcedonia, nas fissuras da rocha em vias de al teração, hä vestigios de um processo que levou tambëm $\vec{a}$ precipitação de silicatos de Mg enriquecidos ou não em $\mathrm{Ni}$ (sērie kerolita-pimelita). Estes, ao conträrio do quartzo, representam uma retenção apenas passageira do $\mathrm{Si}$ e $\mathrm{Mg}$, de- 
REPARTIÇAO DOS ELEMENTOS QUTMICOS ENTRE OS MINERAIS

$\mathrm{H}_{2} \mathrm{O}^{+}$ Si

serpentina

R

brucita

olivina

verniculita

serpentin

vermiculita

piroxênio

olivina

serpentina

brucita $+\mathrm{CO}_{3}^{--}$

vermiculita

piroxēnio

$\begin{array}{lll}\text { serpentina } & \text { olivina } & \text { olivina } \\ \text { verniculita } & \text { serpentina } & \text { serpentina } \\ \text { amorfos Si fe } & \text { vermiculita } & \text { vermiculita } \\ \text { esmectita } & \text { piroxênio } & \text { piroxênio } \\ & \text { amorfos si fe esmectita } \\ & \text { quartzo } & \text { pimelita } \\ & \text { esmectita } & \\ & \text { pimelita }\end{array}$

serpentina

verniculita

serpentina

vermiculita

amerfos $\mathrm{Si} F \mathrm{Fe}$ piroxento

amorfos $\mathrm{Si} F \mathrm{Fe}$

goethita

quartzo

esmectita

pimelita

vermiculita

verniculita

quartzo

esmectita

goethita

vermiculita

Lv goethita

\section{vermiculita}

quartzo serpentina

vermiculita

piroxênio

\section{vermiculita \\ esmectita}

magnetita

cromita

amorfos Si $\mathrm{Fe}$

esmectita

smectita

pinelita

vermiculita magnetita

cromita

amorfos Si $\mathrm{Fe}$

esmectita

goethita

goethita

cromita

vermiculita

esmectita

goethita

cromita

hematita

vermiculita
AI

$\mathrm{Cr}$

$\mathrm{Co}_{0} \mathrm{Mn}$

$\mathrm{Ca}$

$N i$

vermiculita cromita

piroxēnio

cromita

piroxênio

$\mathrm{CO}_{3}^{--}$

olivina

serpentina

\section{vermiculita cromita}

piroxénio

piroxēnio

serpentina

pinelita

anorfos $\mathrm{Si} \mathrm{Fe}$ piroxênio

piroxēnio goethita

cromita

esinectita

goethita

vermiculita cromita

cromita goethita

esmectita

goethita

verniculita

cromita

cromita

goethita

goethita serpentina

pimelita

amorfos $\mathrm{Si} F \mathrm{Fe}$

goethita

goethita 
saparecendo nos nĩveis mais alterados.

Nas rochas portadoras de piroxēnio, a altera ção deste mineral tambëm acaba levando a uma evacuação mais ou menos completa dos elementos solüveis (Si, $\mathrm{Mg}$ e $\mathrm{Ca}$ ). No entanto, existe uma fase transitöria de retenção de parte do $\mathrm{Si}$ e Mg, que,juntamente com o Fe e um pouco de Al, leva à formação de nontronita, principal constituinte de certos horizontes de alteração do piroxenito.

Uma pequena parte do Si e Mg permanece at $\overrightarrow{\mathrm{e}}$ os niveis mais alterados de laterita vermelha, sob forma de vermiculita nos dunitos e de "mica" da sērie hidrobiotita vermiculita nos piroxenitos.

A perda dos elementos solüveis traz, por si sō, como consequéncia, a relativa concentração dos elementos menos möveis. O $\mathrm{Fe}$, que, com o si e o $\mathrm{Mg}$, perfaz $90 \%$ do dunito serpentinizado, apresenta um comportamento simëtrico ao desses dois, isto $\vec{e}$, seu teor aumenta à medida que os teores deles diminuem. Liberado pela dissolução da olivina, fica retido inicialmente nos buracos então formados, como amorfo associado ao Si; deposita -se tambēm sobre as fibras de serpentina, o que Thes atribui um colorido caracteristico. A alteração prosseguindo, a serpentina acaba por dissol ver-se e o Fe cristaliza-se em goethita e, finalmente, em hematita, na laterita vermelha. Neste horizonte, $\bar{e}$ comum o concrecionamento, resultando num solo constituído por nödulos sub-milimëtricos soltos, dispersos numa matriz fina,fer ruginosa, contendo concreções pisoliticas dispersas (Barbour 1976).

Alēm da concentração quỉmica do Fe por evacuação dos demais constituintes da rocha, ocorre, nas baixadas, uma concentração de Fe devida a fatores mecãnicos: a erosão dos perfis de alteração dos sittios mais elevados car - rega o saprolito e o deposita nas zonas mais baixas. A 1 ate 
rita vermelha, concrecionada e muito rica em fe atinge ai suas maiores espessuras. Devido a oscilações do nivel d'ägua, prōximo aos cōrregos, ocorre cimentação das concreções, formando crostas ferruginosas continuas.

Uma parcela do Fe permanece sob sua forma or $\underline{j}$ ginal, nos minerais que resistiram à alteração, como restos de cromita e vermiculita.

Nos piroxenitos, o Fe tem essencialmente 0 mesmo destino que nos dunitos, concentrando-se residualmente,principalmente sob forma de goethita e hematita. Aqui,po rēm, participa da formação das esmectitas ferrifferas.

$0 \mathrm{Cr}$, elemento que, aparentemente, apresenta os mais altos niveis de concentração nos horizontes de LV, está originalmente na cromita. Este mineral sofre dissolu ção incipiente, de modo que a maior parte do $c r$ permanece na cromita atē os nĩveis mais evoluîdos. Parece provāvel que esta parte do $\mathrm{Cr}$ que entra em solução incorpora-se no retículo da goethita.

$0 \mathrm{Al}$, elemento menor nas rochas ultramäficas, esta principalmente concentrado na vermiculita e nas "micas", ocorrendo, secundariamente nos piroxēnios. Ocorre tam bëm, em pequena quantidade, na cromita. Com a alteração,par te deste Al permanece retido nos minerais residuais, e parte, correspondendo à dissolução da cromita, è solubilizada e incorporada à goethita, apresentando o mesmo destino do Cr. Nos piroxenitos, o Al participa da formação da nontroni ta, quando liberado do piroxēnio, e hä indícios de que, a alteração prosseguindo, ele possa constituir seu prōprio mi neral, a boehmita (vide Ev.Mineralógica).

0 Mn e o co não foram encontrados individuali zados em minerais. Apresentam comportamento correlacionāvel, e as seguintes caracterĩsticas: 
- maior abundância nos dunitos que nos piro xenitos e, portanto, em provāvel associação primāria com a olivina;

- enriquecimento continuo durante a alteração, major do Co que do $M n$;

- concrecionamento nos niveis mais evoluídos, juntamente com o"Fe.

$0 \mathrm{Cu}$, o menos abundante dos elementos citados, estä mais concentrado nos dunitos que nos piroxenitos e sofre enriquecimento não muito acentuado no decorrer da meteorização. Não foi possĩvel determinar em que mineral e como ele se encontra.

A ägua, presente originalmente na serpentina, brucita, vermiculita e "micas", e, portanto, em muito major quantidade no dunito serpentinizado que no piroxenito, acaba sendo encontrada tambem em quase todos os minerais secundärios. Apenas os horizontes mais evoluĩdos são relativamente desidratados, como consequência da passagem goethita $(\alpha \mathrm{FeOOH})$ para hematita $\left(\alpha \mathrm{Fe}_{2} \mathrm{O}_{3}\right)$.

o ciclo mais complexo è o do $\mathrm{Ni}$. Liberado pela dissolução da olivina, precipita provavelmente como hidröxido mais ou menos cristalizado nas fissuras ou descontinuidades da serpentina, ou juntamente com os compostos amorfos silico-ferruginosos. O estudo experimental da a)teração da olivina (Perruchot1971). mostrou que a maior parte do $\mathrm{Ni}$ fica retida nos residuos de sua dissolução. Quando da dissolução da serpentina, o Ni incorpora-se ao retīculo da goethita, do que resulta que os niveis mais ri cos nesta fase tambëm são os mais ricos em Ni. Na LV, a transformação goethita-hematita parece ser acompanhada de uma perda de $\mathrm{Ni}$, o que concorda com os dados experimentais (Nalovic 1971, Nalovic $\xi$ Pinta 1972 e Nalovic $\xi$ Segalen 
1973). Hă, assim, lixiviação vertical do Ni a partir dos horizontes mais evoluĩdos de LV, causando um aporte per descensum, em beneficio dos niveis inferiores do perfil.

Eventualmente, as soluções ricas em $\mathrm{Ni}$ que percolam o perfil podem deixar parte de seu conteüdo em armadilhas constituidas por veios de vermiculita em vias de alteração. Nestes casos, o $\mathrm{Ni}$ estaria, provavelmente, ad sorvido na superficie dos cristais de vermiculita. No passado, quando havia condições mais favoráveis para a neofor mação de silicatos magnesianos tipo talco, o $\mathrm{Ni}$ incorporoú se a este retĩculo. Os vestigios deste processo são as belas ocorrências de garnierita, geralmente associadas a materiais silicificados.

$0 \mathrm{Ni}$, assim como o Fe e os demais elementos residuais, sofre tambëm concentração mecānica, a partir dos antigos perfis erodidos, em direção às baixadas. Este apor te soma-se ao enriquecimento quimico e faz com que seja nestes sîtios topogräficos que se encontrem os majores teo res em $\mathrm{Ni}$.

Nos piroxenitos, o processo de concentração de $\mathrm{Ni}$ ocorre em menor escala, mas basicamente pelo mesmo mecanismo: liberação dos silicatos hipögenos por dissolução e incorporação no retīculo da goethita neoformada. 0 quadro abaixo mostra o teor mëdio de $\mathrm{NiO}$ (\% em peso) em cada fäcies de alteração, para os 2 extremos litolögicos das ultramäficas de Santa $F \vec{e}$.

$$
\text { dunito serp. piroxenito }
$$

$\begin{array}{lll}R & 0,23 & 0,06 \\ S G & 0,91 & 0,10 \\ S F & 1,40 & 0,14 \\ \text { LV } & .1,19 & 0,35\end{array}$




\section{B. Dados Volumëtricos}

Havendo conservação da estrutura do material durante a alteração, $\vec{e}$ possível calcular a quantidade, em peso, de cada öxido por unidade de volume, e comparä-la com a quantidade no mesmo volume de rocha fresca (Bonifas $\xi$ Mi] lot 1955). Assim, foram calculadas as quantidades absolutas de cada componente para cerca de 100 amostras, a partir da anälise quîmica e da medida da densidade aparente. os valo res extremamente baixos de cu impediram uma avaliação adequada de suas perdas e ganhos. $0 \mathrm{Ca}$ e o Mn foram dosados apenas em algumas poucas amostras e, porisso, não foi possível estabelecer mëdias significativas. As variações de $\mathrm{H}_{2} \mathrm{O}^{+}$ não ilustram bem as características do processo pois, como jä foi assinalado anteriormente, ocorrem perdas e ganhos mais ou menos simultāneos que tendem à compensação. A evolu ção dos demais öxidos será tratada para cada tipo litológico e, no caso dos dunitos, para cada sitio topogräfico.

a. Perdas e ganhos no perfil de alteração

\section{a.1. Sobre dunito}

As figuras 34,35 e 36 apresentam as varia ções de teores absolutos em função de um indice de alteração (densidade aparente) para cerca de 60 amostras das topossequencias XXVII e W4. Ressalta imediatamente das figuras que $\mathrm{SiO}_{2}$ e MgO sofrem perda continua e que os outros oxidos permanecem em quantidades mais ou menos constantes, com exceção do $\mathrm{NiO}$, que apresenta um comportamento menos regular.

A evolução do Mgo parece dar-se de maneira mais ou menos linear, isto é, com a diminuição da densidade aparente hä perda continua de $\mathrm{Mg}$ a taxa aproximadamente constante. A sîlica solüvel segue, em grandes traços, a evo 
FIGURA 34

VARIAÇAOO DOS TEORES ABSOLUTOS DE $\mathrm{SiO}_{2}, \mathrm{MgO}_{\mathrm{E}} \mathrm{NIO},:$ EM FUNÇAOO DA DENSIDADE APARENTE
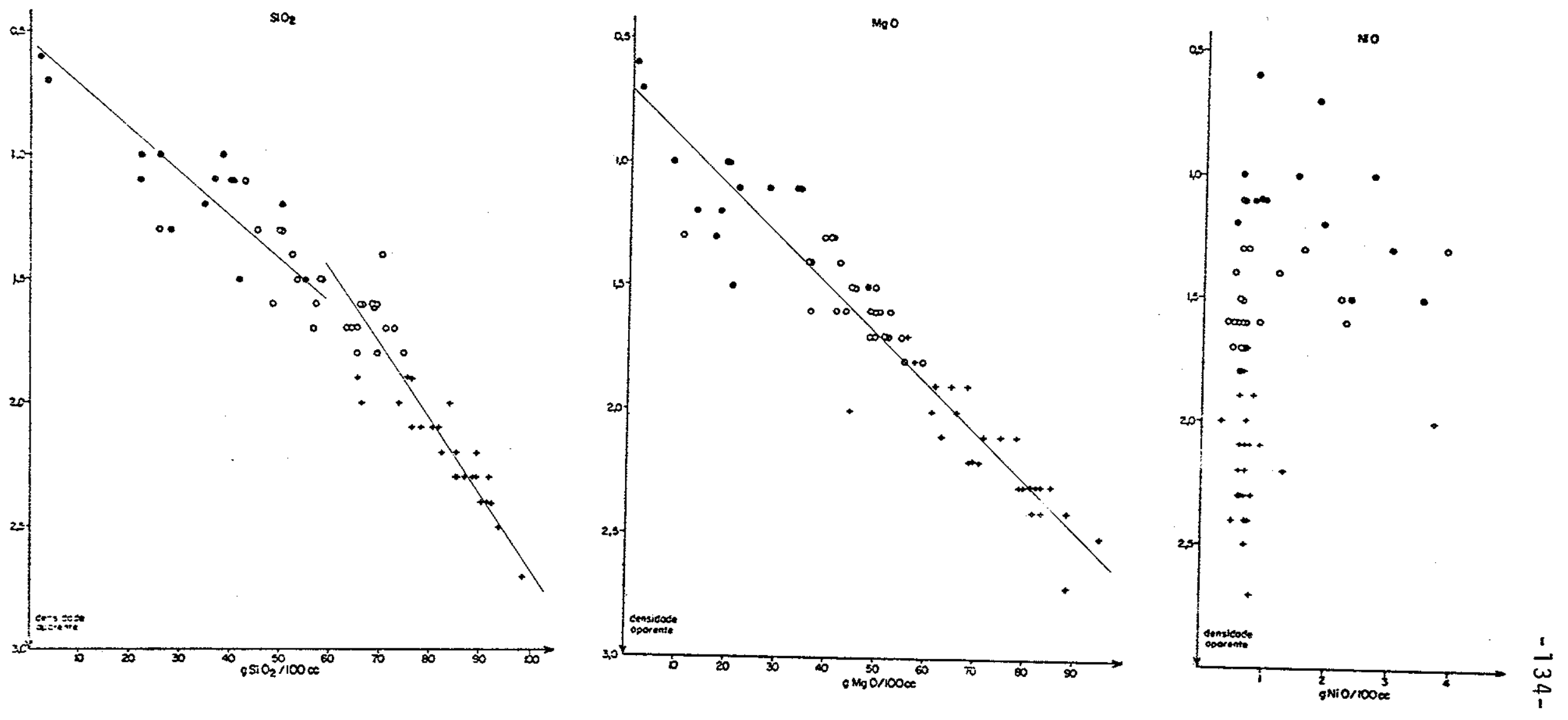


\section{FIGURA 35}

VARIAÇAO DOS TEORES ABSOLUTOS DE $\mathrm{Cr}_{2} \mathrm{O}_{3}$ E $\mathrm{Fe}_{2} \mathrm{O}_{3}$, EM FUNÇAO DA DENSIDADE APARENTE
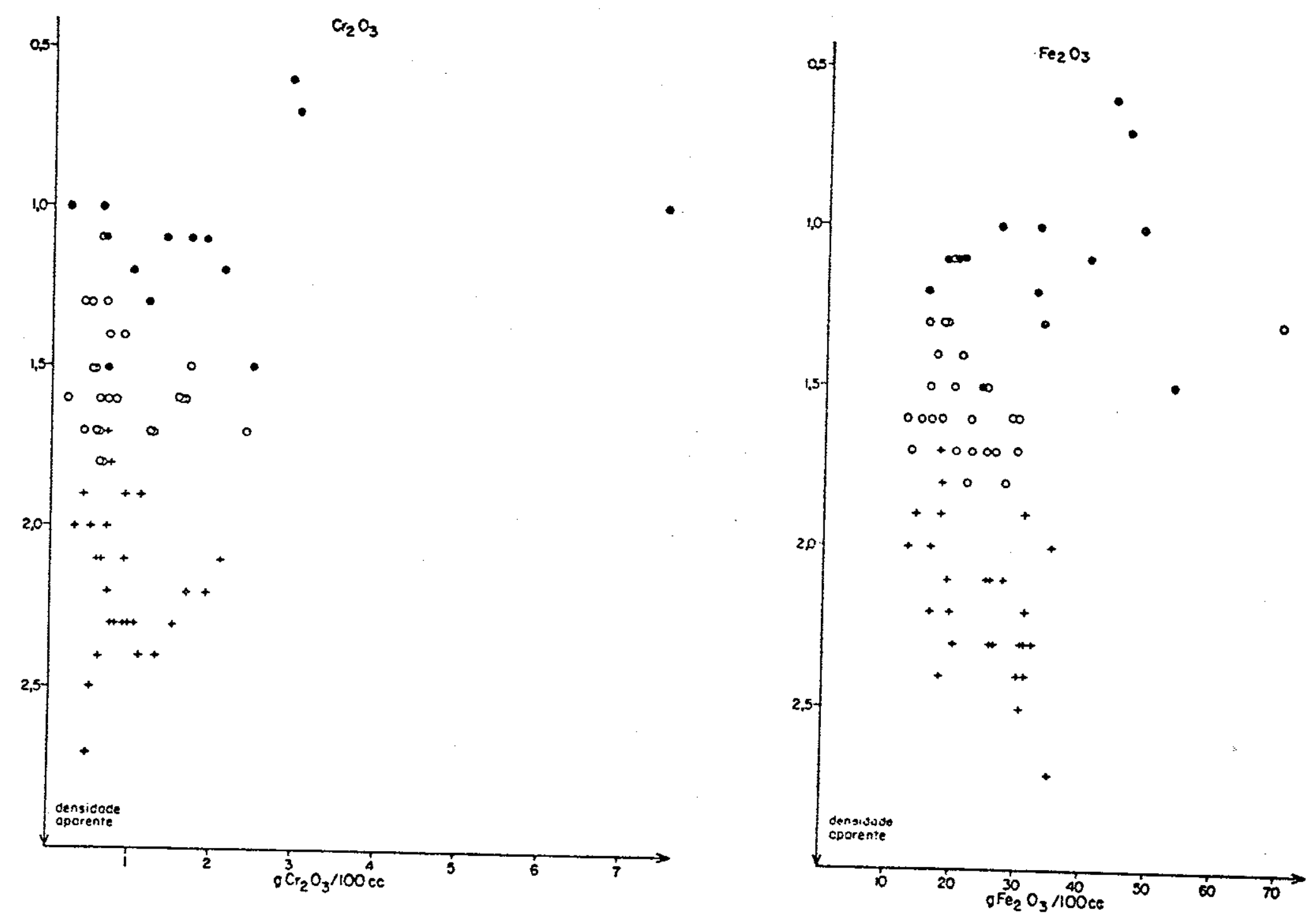
VARIAÇAO DOS TEORES ABSOLUTOS DE AT $2^{\circ}{ }^{\circ} \mathrm{E}$ COO, EM FUNÇAO DA DENSIDAdE APARENTE
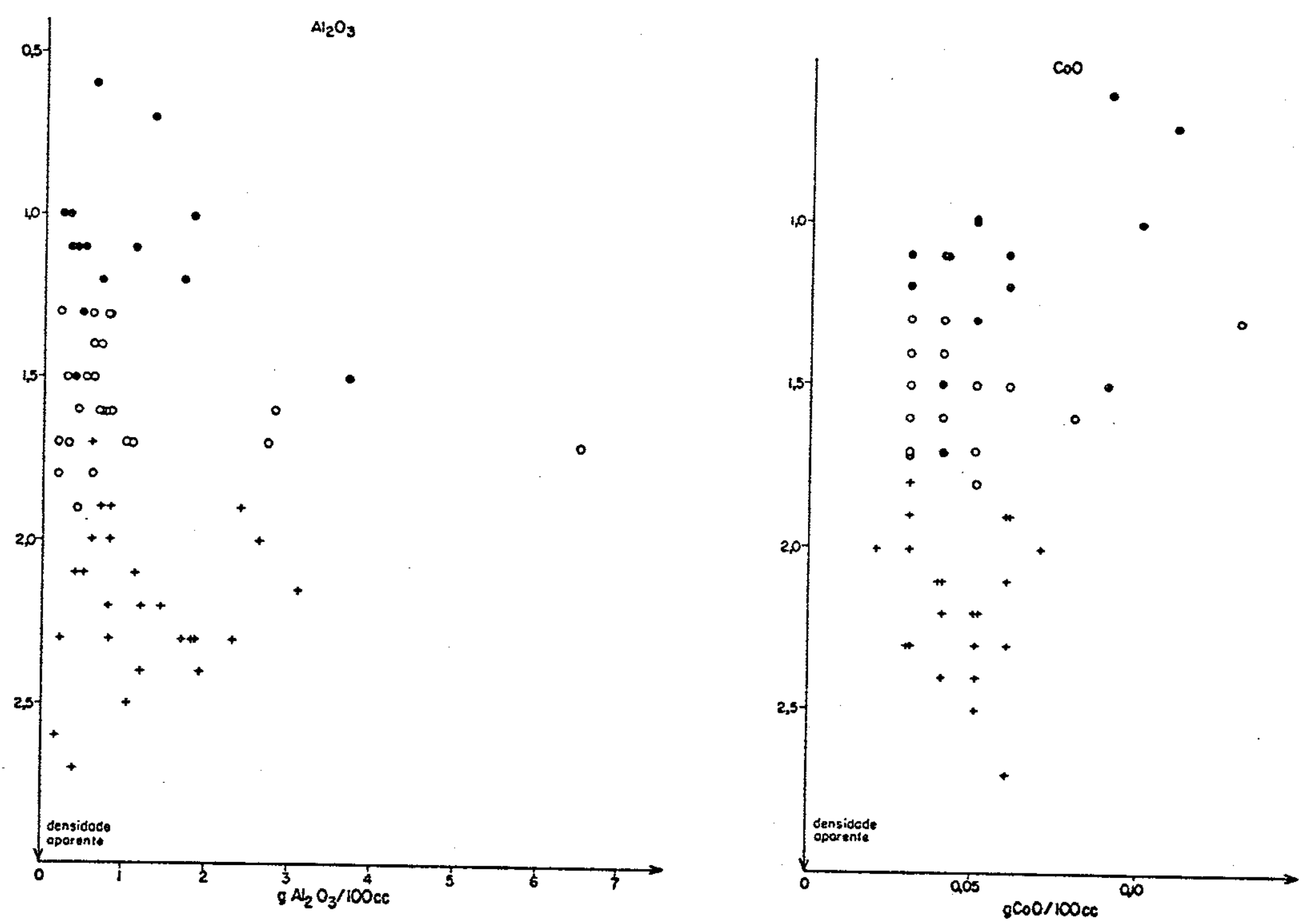
1 ução do Mgo, mostrando gradativa redução em sua quantidade absoluta, à medida que a alteração prossegue. Parece,po rēm, que essa redução ocorre a uma taxa menor que a do $\mathrm{MgO}$ atē densidades prōximas a $1,6, e$, a partir da 7 , a taxas semelhantes às de perda de Mgo, o que é evidenciado pela inclinação das curvas médias (figura 34 ).

A evolução conjunta dos elementos solüveis durante a alteração é representada na figura 37 . Logo no inicio, hā perda apenas de Mgo (cerca de $4 \%$ do Mgo total), - que corresponde à dissolução da brucita e dos carbonatos. Em seguida, dä-se a alteração da olivina, deixando um resỉduo silicoso (perda de Mgo proporcionalmente maior que perda de $\mathrm{SiO}_{2}$ com relação à olivina); a alteração prossegue pela dissolução aproximadamente congruente da serpenti na, em meio de drenagem mais eficiente, devida aos buracos deixados pela olivina. Pode-se dizer que, em mëdia, a sîli ca livre (quartzo $+\mathrm{SiO}_{2}$ mal cristalizada), formada residualmente no inicio do processo e que constitui cerca de $10 \%$ da silica total, permanece até o fim (vide figura 37), onde $B C=D E)$, de modo que o quartzo e a calcedónia encontra dos nos fácies mais alterados correspondem a material herdado dos horizontes menos alterados. Os pontos à esquerda e à direita da reta mēdia que exprime a alteração da serpentina representam, respectivamente, amostras empobreci das e enriquecidas em sîlica livre em relação à mëdia. Mes mo nos casos de grande enriquecimento em relação à média, a quantidade de sīlica total è sempre bem menor que a quan tidade inicial, o que indica que nunca hä enriquecimento absoluto em silica.

A alteração da olivina, estudada experimentalmente (Pedro $\xi$ Delmas 1971 e Delmas 1972), pode levar a uma evacuação preferencial do $\mathrm{Mg}$ em relação ao Si para as drenagens lentas. No caso de drenagem intensa, passa-se o conträrio. Quanto à serpentina, o estudo de sua alteração no laboratōrio (Luce et al. 1972) mostrou que no inỉcio do. 


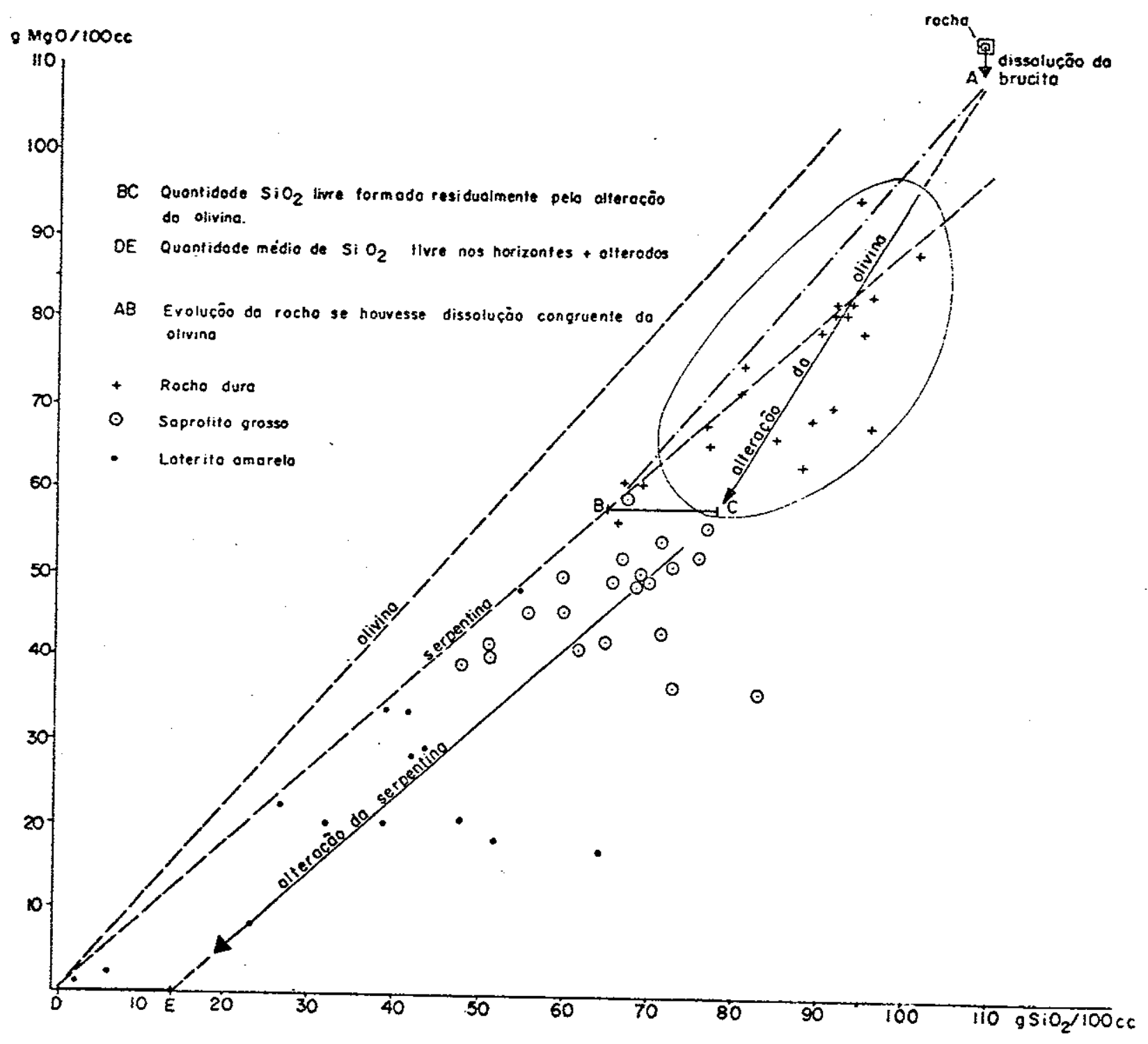

Fig 37 - EVQLUCÃ̃o dOS ELEMENTOS SOLÚVEIS NA ALTERACÃo dOS DUNITOS SERPENTINIZADOS. 
processo pode haver retenção de $S i$, mas que a tendência $\vec{e}$ logo no sentido de uma dissolução congruente.

A tabela 20 mostra o balanço geoquímico du rante a alteração, tomando como material inicial a rocha fresca de referência (tabela 10) e fazendo os cälculos usando quantidades médias dos öxidos dentro de intervalos de densidade aparente. As perdas totais de massa em relação à rocha fresca são, aproximadamente:

$$
\begin{array}{rr}
\text { densidade aparente } & \text { perdas } \\
0,6-1,0 & 66 \% \\
1,1-1,5 & 52 \% \\
1,6-2,0 & 38 \% \\
2,1-2,7 & 20 \%
\end{array}
$$

Na tabela 20 aparecem perdas mais intensas para o MgO que para o $\mathrm{SiO}_{2}$, o que confirma a interpretação da figura 37. A diferença entre a quantidade da silitica solüvel e sĩlica total varia de 2 a $6 \%$ da sillica inicial e corresponde ao quartzo.

A alteração mais recente, portanto, conduz à uma silicificação incipiente e não leva a aumento absolu to na quantidade de sỉjica, mas tão somente a uma perda re 1 ativamente menor desse ōxido em relação ao Mgo. No passado, ao conträrio, houve silicificação bastante intensa, cu jos vestígios são representados pelas crostas silicificadas (amostras 111, 118 e BG0-13). As duas primeiras amos tras correspondem ao boxwork in situ, no alto de um morrote, e a ūitima é um fragmento rolado encontrado na baixada. A tabela $21 \mathrm{~A}$ indica que,para as amostras 111 e 118 , houve retenção praticamente completa da sîlica inicial,e,para a amostra $\mathrm{BGO}-13$, um certo enriquecimento absoluto. $0 \mathrm{Fe}_{2} \mathrm{O}_{3}$ mantëm-se praticamente constante para as amostras $118^{2} \mathrm{e}$ 

BALANÇO GEOQUIMICO PARA AS AMOSTRAS DAS TOPOSSEQUENCIAS XXVII E W4 (CALCULO ISOVOLU
ME: \% DA QUANTIDADE INICIAL DO OXIDO)

$\begin{array}{cccccccccc}\text { D.A. } & \mathrm{MgO} & \mathrm{SiO}_{2} \text { sol. } & \mathrm{SiO}_{2} \text { tot. } \mathrm{NiO} & \mathrm{Fe}_{2} \mathrm{O}_{3} & \mathrm{Cr}_{2} \mathrm{O}_{3} & \mathrm{CoO} & \mathrm{Al}_{2} \mathrm{O}_{3} & \mathrm{n} \\ 0,6-1,0 & -91 & -83 & -81 & +131 & +62 & +69 & +46 & -28 & 5 \\ 1,1-1,5 & -72 & -60 & -54 & +166 & -9 & +13 & -13 & -9 & 18 \\ 1,6-2,0 & -54 & -37 & -35 & +33 & -12 & -6 & -25 & -13 & 23 \\ 2,1-2,7 & -32 & -20 & -17 & +13 & +8 & +5 & -16 & +2 & 18 \\ R^{*} & 41,98 & 39,65 & 39,65 & 0,23 & 8,91 & 0,35 & 0,020 & 0,42 & -\end{array}$

* Dados expressos em \% em peso 
BALANÇO GEOQUIMICO PARA O BOXWORK SILICOSO (CALCULO ISOVOLUME: \% DA QUANTIDADE INICIAL DO OXIDO)

$\begin{array}{cccc}\text { AMOSTRA } & \mathrm{MgO} & \mathrm{SiO}_{2} \text { tot. } & \mathrm{Fe}_{2} \mathrm{O}_{3} \\ 111 & -99 & +1 & +183 \\ 118 & -100 & +1 & -13 \\ \mathrm{BGO-13} & -99 & +48 & -26 \\ R^{*} & 41,98 & 39,65 & 8,91\end{array}$

* Dados expressos em \% em peso

BALANÇO GEOQUTMICO PARA A AMOSTRA 118 EM RELAÇXO A AMOSTRA 111 (CALCULO ISOVOLUME : \% DA QUANTIDADE DO OXIDO EM RELAÇAO A AMOSTRA 113 )

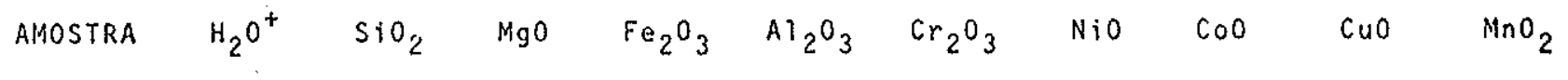
$\begin{array}{lllllllllll}118 & -67 & -2 & -70 & -69 & -80 & -63 & -72 & -75 & -69 & -72\end{array}$ 
BG0-13 e sofre enriquecimento absoluto na amostra 111, certamente devido ao fenōmeno de iluviação de goethita dos niveis superiores. Essas crostas, devem, portanto, representar produto de alteração sob um clima majs antigo, provavelmente mais seco que o atual e de condições de drenagem dificul tadas.

A fim de testar a hipōtese de um esvaziamento progressivo das cavidades do boxwork, devido a processos erosivos, foram calculadas as perdas em valor absoluto para os diversos componentes da amostra 118 em relação à amos tra 111, o que figura na tabela 21B. Fica claro que a hipotese è confirmada: permanência da sijlica e perda de cerca de $2 / 3$ de todos os demais componentes.

Os elementos que sofrem enriquecimento relativo durante a alteração ( $F e, A l$, Co e $\mathrm{Cr}$ ) parecem, na verdade, apenas manter sua quantidade inicial mais ou menos fi xa. Uma avaliação mais precisa do balanço desses elementos fica dificultada pelo fato de apresentarem teores variäveis na rocha fresca. A quantitade inicial de Fe na rocha fresca, por exemplo, vai variar em função do aumento de volume e perda de massa (vide capitulo I), ocorridos durante a ser pentinização. A repartição do $C r$ e do $A l \vec{e}$ heterogênea na rocha-mãe, pois os minerais que principalmente os contēm (cromita e vermiculita) podem concentrar-se ao longo de fra turas. Apesar dessas ressalvas, os cālculos da tabela 20 mostram muito bem que, para os primeiros estägios da alteração, hä realmente conservação da quantidade inicial desses e lementos. Apenas nos niveis mais alterados com densidades aparentes entre 0,6 e 1,0 parece haver para o Fe, $\mathrm{Cr}$ e Co um certo enriquecimento, que pode ser interpretado como re.. sultante de um processo que não se deu estritamente a volu me constante. Assim, um inïcio de compactação nos horizon tes mais superficiais levaria a um falso aumento na quantidade absoluta dos elementos residuais. Uma interpretação al ternativa de aporte mecãnico por iluviação seria possível a 
penas para o Fe,que se encontra sob forma de um mineral fi namente cristalizado, a goethita, mas não explicaria o enriquecimento em $\mathrm{Cr}$ e Co, contidos em partículas de maior tamanho (cromita e concreções, respectivamente).

$0 \mathrm{Ni} \overrightarrow{\mathrm{e}}$ o ünico elemento que apresenta enriquecimento absoluto em todos os niveis de alteração (tabela 20). Sua quantidade absoluta permanece aproximadamente a, mesma na rocha dura, cresce um pouco no saprolito grosseiro e atinge valores máximos no limite SG-LA, para decrescer ligeiramente na laterita amarela bem alterada. Se aceitarmos a hipötese de compactação neste nível, certas a mostras de laterita amarela poderiam mostrar-se at $\vec{e}$ ligeiramente empobrecidas em $\mathrm{Ni}$.

os dados relativos ao perfil G (tabela 22), tratados aqui separadamente por apresentarem grande quant dade de garnierita, revelam a mesma tendência observada pa ra a mëdia das amostras, com a diferença de que as taxas de enriquecimento em Nio são muito altas, chegando a ultrapas sar $1000 \%$. A interpretação desses valores serā discutida $\underline{a}$ diante.

Em resumo, pode-se afirmar que as quantidades absolutas de $\mathrm{MgO}$ e $\mathrm{SiO}_{2}$ decrescem durante a alteração, - $\mathrm{Fe}_{2} \mathrm{O}_{3}, \mathrm{Cr}_{2} \mathrm{O}_{3}, \mathrm{CoO}$ e $\mathrm{Al}_{2} \mathrm{O}_{3}$ permanecem aproximadamente constantes, sendo o $\mathrm{NiO}$ o ünico oxido que sofre enriquecimento absoluto. Como o balanço para o $\mathrm{Ni}$ é positivo ao lon go de todo o perfil de alteraçäo in situ, conclui-se que excedente desse metal provenha de camadas superiores jä erodidas.

a.2. Sobre peridotito e piroxenito

As tabelas 23 e 24 mostram o balanço geoqui mico calculado para perfis sobre piroxenito e sobre perido 
TABELA 22

BALANÇO GEOQUIMICO PARA O PERFIL G (CALCULO ISOVOLUME: \% DA QUANTIDADE INICIAL DO OXIDO)

$\begin{array}{lrrrr}\text { AMOSTRA } & \text { SiO } t \text { tot. } & \text { MgO } & \mathrm{NiO} & \mathrm{Fe}_{2} \mathrm{O}_{3} \\ 108(1,7) * & -39 & -55 & +458 & +2 \\ 105 \mathrm{~A}(1,7) & -43 & -52 & +147 & +9 \\ 109(1,9) & -39 & -47 & +481 & +28 \\ 107(2,4) & -19 & -41 & +1340 & +81 \\ 104(2,3) & -13 & -31 & +30 & -18\end{array}$

* Dados entre parênteses: densidade aparente 
TABELA 23

BALANÇO GEOQUIMICO PARA O PERFIL SOBRE PIROXENITO (CALCULO ISOVOLUME: \% DE QUANTIDADE INICIAL DO OXIDO)

\begin{tabular}{|c|c|c|c|c|c|c|c|c|c|c|}
\hline AMOSTRA & $\mathrm{SiO}_{2}$ & $\mathrm{MgO}$ & $\mathrm{Fe}_{2} \mathrm{O}_{3}$ & $\mathrm{~A}]_{2} \mathrm{O}_{3}$ & $\mathrm{Cr}_{2} \mathrm{O}_{3}$ & NiO & CoO & CuO & $\mathrm{MnO}_{2}$ & $\mathrm{CaO}$ \\
\hline $99(0,9)^{*}$ & -77 & -83 & -12 & -9 & -28 & -18 & -53 & -45 & -35 & -95 \\
\hline $98(1,0)$ & -72 & -76 & -32 & -77 & -45 & -49 & -53 & -40 & -56 & -88 \\
\hline $93(1,3)$ & -64 & -71 & -8 & +39 & -57 & -8 & -46 & $-7 \cdot 3$ & -39 & -95 \\
\hline $97(1,4)$ & -62 & -61 & +1 & -7 & -11 & -36 & -27 & -32 & -34 & -71 \\
\hline$R \div \div(3,3)$ & 50,57 & 16,17 & 7,68 & 1,93 & 0,11 & 0,06 & 0,011 & 0,005 & 0,11 & 20,54 \\
\hline
\end{tabular}

* Densidade aparente

** Dados expressos em \% em peso 
TABELA 24

BALANCO GEOQUIMICO PARA OS PERFIS SOBRE PERIDOTITO (CALCULO ISOVOLUME: \% DA QUANTIDADE DE OXIDO NO FACIES MENOS ALTERADO)

$\begin{array}{cccc}\text { AMOSTRA } & \mathrm{SiO}_{2} & \mathrm{MgO} & \mathrm{NiO} \\ 131(1,9) * & -58 & -46 & +334 \\ 129 * *(2,7) & 56,9 & 22,4 & 0,13\end{array}$

Perfil Slow4

\begin{tabular}{cccc} 
AMOSTRA & $\mathrm{SiO}_{2}$ & $\mathrm{MgO}$ & $\mathrm{NiO}$ \\
$89(1,3)$ & -65 & -73 & +66 \\
$88(1,4)$ & -52 & -55 & +9 \\
$87(1,7)$ & -32 & -30 & +10 \\
$86 * *(2,2)$ & 36,1 & 10,0 & 0,32 \\
& \multicolumn{4}{c}{ Perfil Pe }
\end{tabular}

* Densidade aparente

** Dados expressos em \% en peso 
tito. As amostras referentes ao perfil pe contëm grande quantidade de piroxënio, enquanto que as do perfil slow4 estão mais prōximas de um dunito. Para o perfil py, a rocha de referēncia é aquela mencionada na tabela 2. Apresen ta razão $\mathrm{MgO} / \mathrm{SiO}_{2}=0,32$, praticamente coincidente com a do piroxēnio $(0,33)$. A anālise modal jă havia, aliās, revelado que este constituinte perfaz $90 \%$ da rocha. Para os peri dotitos, que variam na composição numa ampla faixa, não $\overline{\mathrm{e}}$ adequado propor os dados de anāilise de uma rocha fresca co mo referēncia. Porisso, apenas para fins comparativos, rea lizou-se o balanço para as amostras mais alteradas em função da amostra menos alterada do perfil.

Nos piroxenitos, a alteração leva a uma dis soluçăo intensa do piroxênio e à neoformação de nontronita. As anālises mostram perda intensa e progressiva de $S i$, $\mathrm{Mg}$ e $\mathrm{Ca}$, perda moderada de $\mathrm{Cr}, \mathrm{Co}, \mathrm{Cu}$ e $\mathrm{Mn}$ e perda menor em $\mathrm{Ni}, \mathrm{Al}$ e $\mathrm{Fe}$, o que resulta num enriquecimento relativo

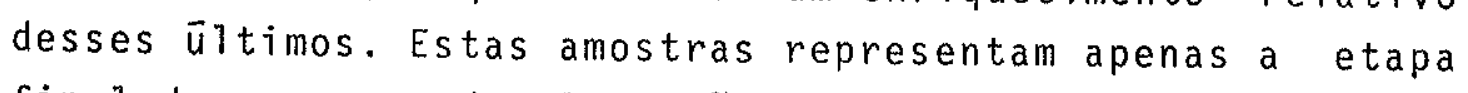
final do processo de alteração com conservação de estruturas, quando a rocha ja perdeu cerca de $2 / 3$ de sua massa $i-$ nicial. o caräter expansivo das esmectitas pode levar a um certo aumento de volume das amostras alteradas, de modo que, de fato, as perdas seriam um pouco menos importantes.

Os peridotitos têm comportamento intermedia rio entre dunitos e piroxenitos: as amostras do perfil pe aproximam-se mais dos piroxenitos, e as do perfil slow4, menos ricas em piroxënio, assemelham-se aos dunitos. 0 cā] culo do balanço relativo à amostra mais fresca indica que a alteração prossegue com perda de $\mathrm{MgO}$ e $\mathrm{SiO}_{2}$, mas com enriquecimento em $\mathrm{NiO}$, embora os produtos de alteração de pe ridotito não cheguem a constituir-se em minērio.

A figura 38 mostra a evolução de $\mathrm{MgO}$ e $\mathrm{SiO}_{2}$ na fase final de alteração dos peridotitos e piroxenitos. os pontos relativos às amostras do perfil pe e do perfil 


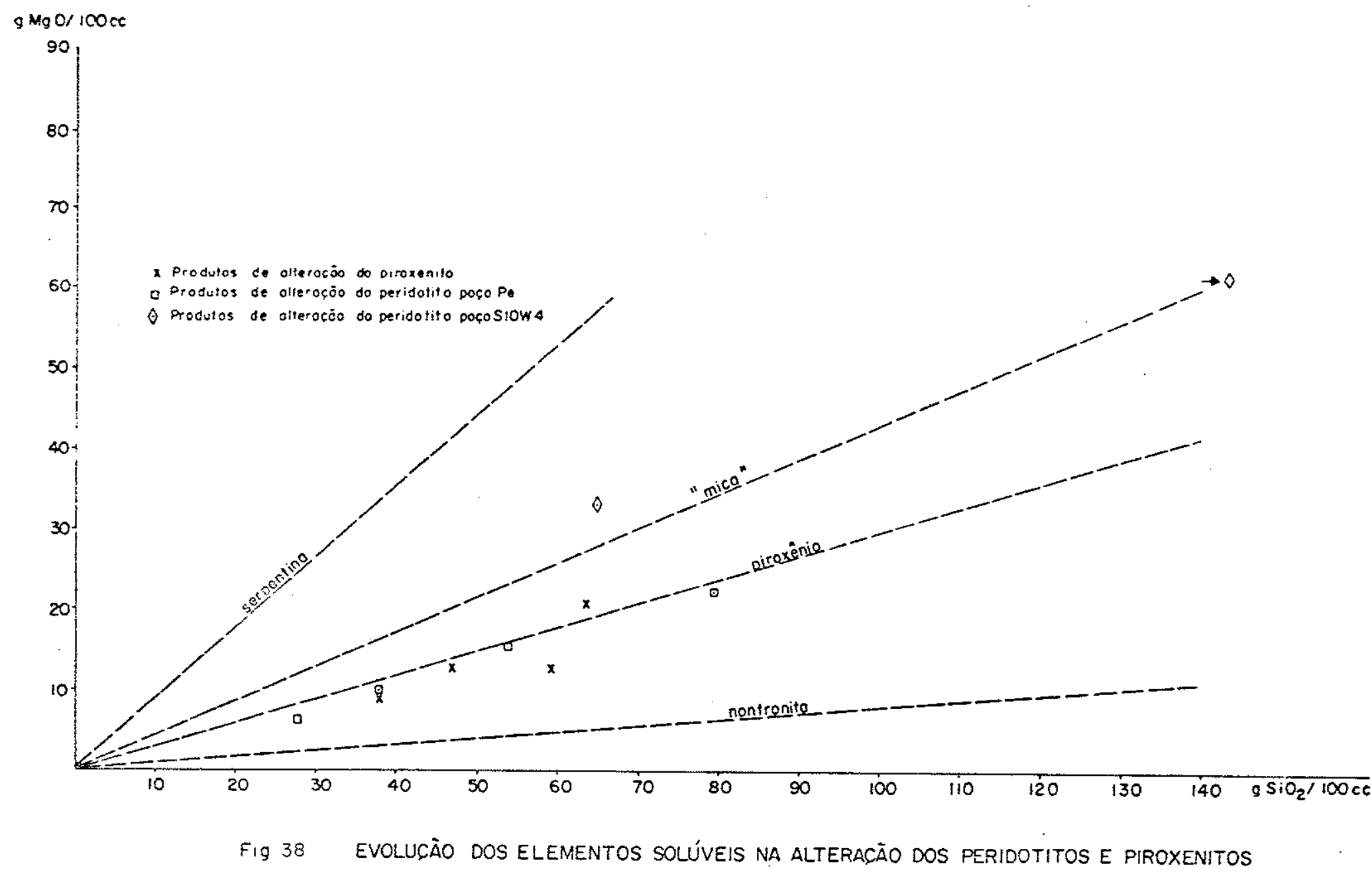


Py situam-se aproximadamente em torno da reta de dissolução do piroxênio. E que esta reta ē intermediāria às da mica e da nontronita, principais constituintes destas amostras. Por outro 1ado, embora a quantidade de nontronita seja significativa nestas amostras, ela não o è em rela ção à rocha fresca, de densidade 3 vezes maior. Assim, a a)teração do piroxenito fica caracterizada muito mais por uma forte dissolução do piroxênio que pela quantitativa mente discreta formação de nontronita.

\section{b. Perdas e ganhos na topossequência}

A investigação do comportamento dos elemen tos quimicamente möveis no perfil de alteração $(\mathrm{Mg}, \mathrm{Si}$ e $\mathrm{Ni}$, , a longo da topossequência, poderā trazer informações sobre a possibilidade de aportes laterais e verticais. Pa ra atingir esses objetivos, o cālculo do balanço desses $\overline{3}$ elementos para as amostras das topossequencias XXVII e W4 foi desdobrado pelos 4 sitios topogräficos jä definidos: topo, encosta, sope e baixada.

Quanto ao Mg e ao Si, o cälculo do balanço em cada setor da paisagem mostra que as perdas ocorrem sempre aproximadamente nas mesmas proporções, qualquer que seja o setor considerado (tabela 25). O estudo da evo lução mineralögica jă havia, aliäs, demonstrado que näo hä neoformações sílico-magnesianas nos pontos mais baixos do relevo, para onde, naturalmente, convergem as äguas ricas em elementos solubilizados das partes mais altas. Da mesma forma, tambēm não se encontra uma maior quantidade de quartzo nas baixadas. Estes dados detalham e confirmam a afirmação de que o fenömeno da silicificação não ë significativo atualmente. Assim, não sö os dados relativos ao balanço da sîlica tomados em conjunto indicam que, durante a alteração, não se dã aumento na quantidade absoluta deste öxido, mas, tambëm, os dados considerados por segmento 
TABELA 2.5

BALANÇO GEOQUIMICO DA SiO${ }_{2}$, MgO E NIO, POR SETOR DA TOPOSSEQUENCIA (CALCULO ISOVOLUME: \% DA QUANTIDADE INICIAL. DE OXIDO)

$\begin{array}{ccccc} & \text { TOPO } & \text { ENCOSTA } & \text { SOPE } & \text { BAIXAOA } \\ \text { LA } & - & -78 & -86 & -84 \\ \text { SG } & -59 & -60 & -59 & -66 \\ \text { RD } & -34 & -39 & -34 & -40\end{array}$

MgO

TOPO

ENCOSTA

SOPE

BAIXADA

$\begin{array}{ll}\text { LA } & - \\ S G & -35 \\ \text { RD } & -15\end{array}$

$-68$

$\begin{array}{ll}-72 & -71\end{array}$

$-44$

$-39$

$-44$

$-23$

$-19$

$-27$

$\mathrm{SiO}_{2}$

$$
\text { D. A. }
$$

TOPO

ENCOSTA

SOPE

$B A I X A D A$

$0,6-1,0$

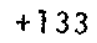

$+70$

$+314$

$1,1-1,5$

$-22$

$+11$

$+155$

$+436$

$1,6-2,0$

$-22$

$2,1-2,7$

$+9$

$+6$

$-9$

$+373$

$+8$

$+2$

$+45$

NiO 
da topossequencia confirmam essa tendēncia. Nem mesmo perdas relativamente menores de $\mathrm{SiO}_{2}$ ocorrem na baixada.

Com relação ao Ni, a tabela 20 jä havia mos trado que o balanço ë sempre positivo, isto $\bar{e}$, desde a RD atē a LA, o volume unitärio da amostra apresenta maior quantidade de NiO que o mesmo volume de rocha fresca. 0 desdobramento do balanço pelos värios setores da paisagem. indica, entretanto, que esse acrëscimo não se dä igualmen te em cada setor. A figura 39 mostra a quantidade absolum ta de NiO de cada amostra, em função de sua densidade aparente, para os 4 sitios topogräficos considerados; a ta bela 25 resume esses dados, exprimindo as perdas e ganhos mëdios em porcentagem.

Nos topos, onde os perfis são decapitados, a florando apenas a rocha pouco alterada, parece não haver perdas nem ganhos significativos. 0s valores utilizados na figura 39 excluem as amostras do poço $G$, tambēm em posição de topo e que são extremamente enriquecidas em Ni (tabela 22). Este enriquecimento, devido ao movimento des cendente do $\mathrm{Ni}$ no antigo perfil de alteração e à consequente precipitação de garnierita nas descontinuidades da rocha na base do perfil, deve ter ocorrido durante a fase de laterização Sul-americana e, talvez, tenha sido retoma da de maneira incipiente no ciclo Velhas. Esses depösitos de $\mathrm{Ni}$ correspondem, portanto, assim como o boxwork de $\mathrm{SiO}_{2}$, a vestigios de processos de um passado remoto e que não estão mais ocorrendo atualmente; hoje, em pleno perïo do erosivo, a tendēncia nos topos não e no sentido de én riquecimento em $\mathrm{NiO}$.

Nas encostas, apenas amostras bem alteradas de LA mostram enriquecimento absoluto. 0 movimento räpido das äguas descendentes, percolando o perfil mais intensamente em seus niveis mais porosos, permitiu que a goethita em vias de formação incorporasse o $\mathrm{Ni}$ nelas contido. Os 

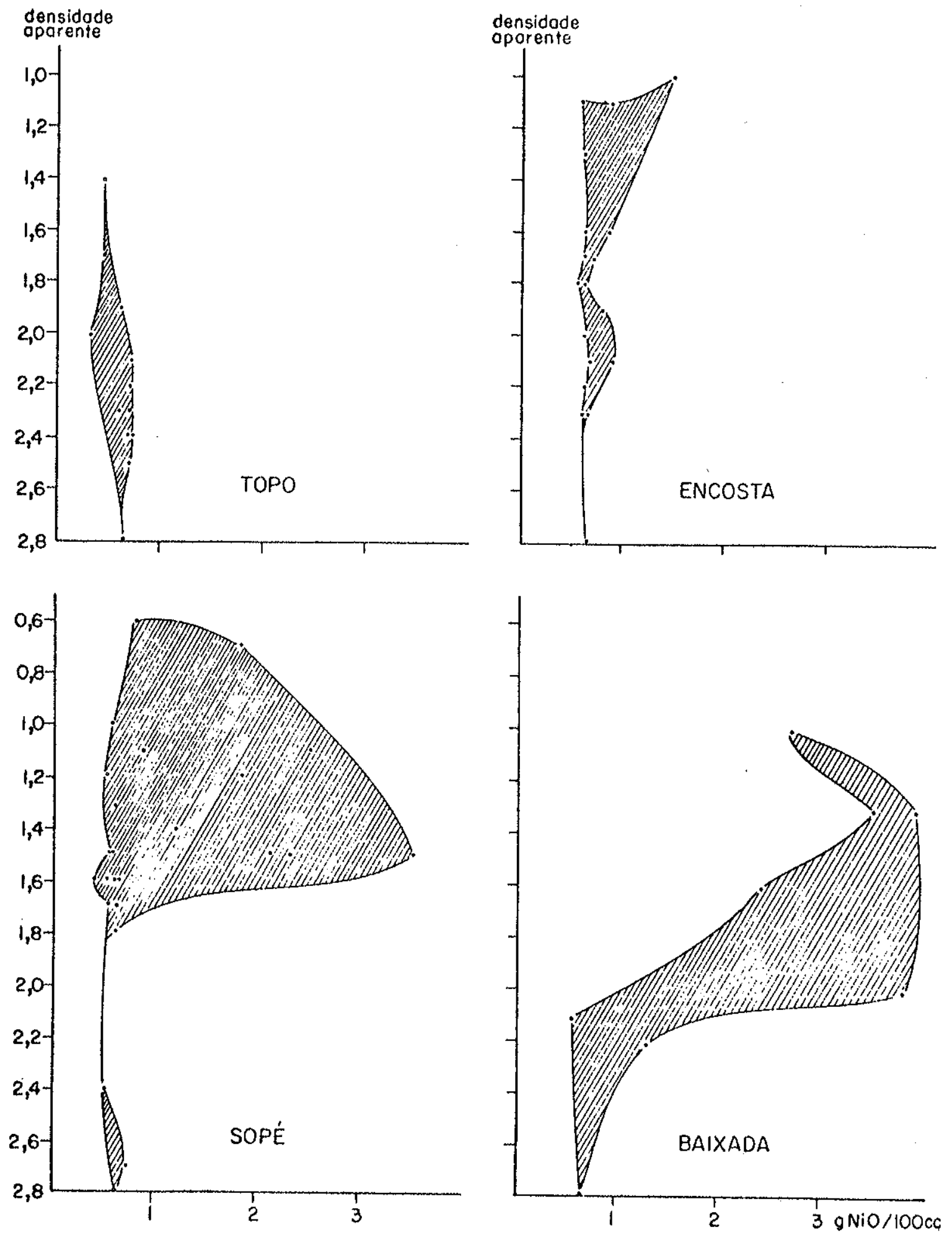

Fig 39- BALANCYO DO NIO POR SETOR DA TOPOSSEQUÊNCIA CALCULO ISOVOLUME gNiO/100 cC. 
fäcies de rocha pouco alterada e saprolito grosseiro perma necem com a quantidade de $\mathrm{Ni}$ aproximadamente igual à origi nal.

Em direção aos segmentos mais planos da pai sagem, onde a circulação das äguas se faz mais lentamente, a alteração conduz à acumulação de Ni tambēm no saprolito grosso e na rocha dura. Assim è que, no sope dos morros, amostras com densidade aparente acima de $1,5 \mathrm{j} \bar{a}$ são enrique cidas e, nas baixadas, esse processo atinge mesmo a rocha pouco alterada. Nestes sitios, o perfil de alteração ë coberto por uma camada de cerca de $3 \mathrm{~m}$ de espessura de lateri ta vermelha, com teores relativamente elevados em NiO (cerca de $1 \%$ em peso). Esta laterita $\bar{e}$, em parte, produto da erosão dos antigos perfis de topo, depositados e compactados nas āreas mais baixas, e vem sofrendo atualmente empobrecimento em $\mathrm{NiO}$, em benefício dos horizontes de alteração subjacentes.

Em suma, o $\mathrm{Ni}$ contido no perfil de altera ção in situ dos segmentos mais baixos da paisagem represen ta uma soma de 3 parcelas:

- Ni contido no material de origem;

- Ni trazido por aporte lateral, atravēs das äguas que o dissolveram dos antigos perfis de topo;

- Ni trazido por aporte vertical, a partir da laterita vermelha.

Na LV das baixadas, o Ni tem origem dupla, como a pröpria LV:

- uma parte foi trazida mecanicamente a par tir dos antigos perfis sul-americanos; 
ção da LA.

- uma parte ē residual, formada pela altera c. Conclusões

0 cālculo isovolume permitiu quantificar os ganhos e perdas no perfil de alteração e estabelecer hipoteses explicativas a respeito do movimento dos elementos quỉmicos pelos värios setores da topossequência.

Como jä foi visto, o processo dominante atualmente em Santa $\vec{F} \vec{e}$ a laterização, que se caracteriza pela lixiviação mais ou menos completa do Si e do $\mathrm{Mg}$, e pela retenção do $\mathrm{Fe}$.

Dentre os solüveis, o Mg è totalmente leva do pelas äguas de drenagem, enquanto que cerca de $10 \%$ da quantidade inicial de si fica retida, sob forma de quartzo e calcedonia. E o que acontece, de modo geral, em qualquer sítio topogräfico, dos topos às baixadas.

No passado, as condições de clima e de drenagem permitiram a evacuação do $\mathrm{Mg}$, mas não a do Si, que ficou retido, praticamente em sua totalidade, no perfil de alteração. Testemunham este processo as crostas silicifica das in situ no alto de alguns morrotes,e seus fragmentos remanejados pela erosão e espalhados pelas baixadas. Algumas dessas estruturas silicosas em boxwork podem mesmo mos trar enriquecimento absoluto em sĩlica.

Os elementos residuais, Fe, Cr, Co e Al não migram quimicamente, permanecendo no perfit, aproximadamen te em suas quantidades iniciais. Sofrem, porëm, transporte mecānico em direção aos nĩveis inferiores da paisagem. Assim, um manto coluvionar lateritico recobre toda a baixada. Nos sopēs, acumulam-se concreções formadas nos horizon 
tes superiores do perfil de alteração e roladas morro aba xo. Quando atingem a planicie, pröximo aos eixos de drenagem e, portanto, sujeitas mais intensamente às oscilações do nīvel hidrostático, acabam por soldar-se, constituindose em crostas ferruginosas.

Uma escala de mobilidade dos elementos quimicos pode ser proposta, a partir do cálculo isovolume e do cālculo das taxas de concentração. Para as rochas de Santa $\vec{F} \vec{e}$ a seguinte:

$$
\mathrm{Ca}>\mathrm{Mg}>\mathrm{Si}>\mathrm{Ni}>\mathrm{Mn}>\mathrm{Co}, \mathrm{Fe}, \mathrm{Al}, \mathrm{Cr}
$$

Não $\vec{e}$ muito diferente da escala proposta por. Trescases 1969, para a mobilidade dos elementos do maciço ultrabāsico da Nova Caledōnia. A diferença mais marcante $\vec{e}$ que, neste caso, a mobilidade do Mg em relação ao Si podia ser maior ou menor dependendo da estação do ano considerada. 0 nivel de detalhe deste resultado so $\overrightarrow{0}$ póde ser obtido atraves do estudo sistemätico das äguas que dre nam o maciço.

Os serpentinitos do Alto Volta tambēm apresentam uma escala de mobilidade semelhante (Pion 1979), com exceção da ordem $\mathrm{Ca}>M g$, que $\mathrm{T} \bar{a} \bar{e}$ invertida.

Apesar de o processo de alteração ser essen cialmente o mesmo para todas as variedades de rochas ultra mäficas, nos pormenores, hä pequenas variações. As rochas portadoras de piroxēnio alteram-se retendo transitoriamente parte do Si, $\mathrm{Mg}$ e $\mathrm{Fe}$, sob forma de nontronita, enquanto que,para os dunitos serpentinizados, a tendēncia $\vec{e}$ no sentido da retenção inicial de $S i$ e Fe como amorfos. Os horizontes mais evoluidos, desenvolvidos sobre os 2 tipos 1ito1ögicos, indicam uma convergēncia dos processos para a formação de öxidos e hidröxidos de Fe. 
$0 \mathrm{Ni}$, de comportamento intermediārio entre os elementos solüveis e residuais, sofre movimentos quīmicos e mecãnicos na superficie. Na base do perfil de altera ção, entra em solução quando do ataque da olivina; sob a influëncia do meio fortemente alcalino aí existente, preci pita sob forma de hidrōxido mais ou menos mal cristaliza do, ou juntamente com o Si e o Fe amorfos, colorindo as fibras de serpentina, ou em suas descontinuidades. Dai um ligeiro enriquecimento absoluto na rocha pouco alterada.

Quando a serpentina se dissolve, esse $\mathrm{Ni}$ e mais aquele contido em seu retículo são liberados, uma par te e levada em solução, e a outra permanece incorporada ao retĩculo da goethita em vias de formação. Na passagem goethita-hematita hä novamente liberação de $\mathrm{Ni}$.

As soluções que percolam lateralmente os perfis são, portanto, ricas em Ni. Essas äguas alteram os silicatos hipögenos a juzante, e deixam parte de seu conteu do em Ni na goethita, o que eleva a quantidade absoluta de $\mathrm{Ni}$ nesses horizontes. Na baixada, o manto coluvionar laterîtico,trazido pela erosão dos antigos perfis de topo, $\bar{e}$ ou tra fonte de $\mathrm{Ni}$. As äguas que o atravessam verticalmente carregam o $\mathrm{Ni}$ liberado pela passagem goethita-hematita e vão depositā-lo nas camadas subjacentes. Esses fatores são os responsäveis por taxas de enriquecimento absoluto em $\mathrm{Ni}$ que chegam atē a 500\%, na região de baixada, situando-se em torno de um valor mëdio de $150 \%$, nos niveis mais enriquecidos.

Os jazimentos de $\mathrm{Ni}$ formados do modo acima descrito são resultado de uma evolução sub-atual a atual, relacionada ao ciclo Velhas, e vem ocorrendo a partir do Quaternärio inferior. No passado, durante o periodo de laterização sul-americano, quando da formação das crostas si licosas, alëm da retenção do si sob forma de quartzo ou calcedōnia, precipitaram tambëm, na base do perfil, silica 
tos magnesianos do tipo "talco" hidratado que puderam incor porar o $\mathrm{Ni}$ lixiviado das camadas superiores, levando a taxas de enriquecimento absoluto neste elemento a mais de $1000 \%$. Os vestigios deste processo, veios de garnierita associados ou não ao quartzo, que tambēm pode incorporar algum $\mathrm{Ni}$ (crisopräsio), encontram-se na base dos perfis sul-a mericanos (alto dos morrotes) ou rolados pelas baixadas. Ain da durante a laterização sul-americana, deve ter ocorrido, no perfil, migração do $\mathrm{Ni}$ per descensum, o que levou a uma certa concentração deste elemento, nos horizontes inferio res. E porisso que as lateritas vermelhas coluvionares que ocupam as baixadas, e que nada mais são senäo as lateritas sul-americanas remanejadas, apresentam teores relativamente elevados em NiO (cerca de $1 \%$ ). 
CAPITULO III

A EVOLUÇAO GEOQUIMICA AO NIVEL DA PAISAgEM E A GENESE DA JAZIDA DE NI

Neste capĩtulo, serä feita a integração dos dados quimicos e mineralögicos relativos às rochas ultramä ficas de Santa $F \vec{e}$ e seus produtos de alteração, ao nivel da paisagem. Esta sîntese sō serā completa, se compreender tambēm a dimensão temporal, visto que a repartição espacial dos fãcies de alteração atualmente encontrada é fruto de uma sērie de eventos que vem se sucedendo desde a época em que o maciço aflorou na superficie. E neste contexto que serā discutida a gênese da jazida de $\mathrm{Ni}$ de Santa Fé.

De modo geral, vārios são os fatores que con trolam a formação de jazidas lateriticas de Ni (Norton 1973, Lelong 1976):

- Rocha-mãe - As lateritas niquelïferas formam-se apenas a partir de rochas originalmente ricas em $\mathrm{Ni}$, isto $\vec{e}$, rochas ultrabäsicas, e, entre elas, especialmente o dunito $(0,2$ a $0,3 \%$ de NiO, segundo Vinogradov 1962 e Kuhn 1968). Um certo grau de serpentinização e fraturamento são fatores positivos para o enriquecimento de $\mathrm{Ni}$.

- clima - Sob clima seco, o intemperismo $\vec{e}$ incipiente, e não se desenvolvem jazidas. Em clima quente e muito úmido, a alteração avança mais, e todo o Mg e o Si são prontamente evacuados, formando-se jazidas apenas por enriquecimento residual. Os climas subtropicais ou tropicais de estações contrastadas são os ideais para o enrique cimento em $\mathrm{Ni}$, pois permitem que se desenvolva, na base do 
perfil, um horizonte silicatado, onde o $\mathrm{Ni}$ pode ser aprisio nado.

$$
\text { - Tempo - Sob climas agressivos, em pouco }
$$

tempo formam-se espessos perfis de alteração. Se o clima for muito seco, o intemperismo è menos räpido, e a formação de grandes concentrações de $\mathrm{Ni}$ implica numa longa duração de tempo. Se a erosão for intensa, facilitada por uma vegetação não muito desenvolvida, o depösito pode ser destruĩdo mais rapidamente do que $\vec{e}$ formado.

- Relevo e atividade tectônica - Nas encos tas ingremes, a erosão remove as lateritas antes que o $\mathrm{Ni}$ possa ser concentrado. Sobre regiões planas, os perfis têm mais chance de se desenvolver. Uma atividade tectónica mode rada, que provoque o rejuvenescimento do relevo, é positiva para o enriquecimento em $\mathrm{Ni}$, pois um primeiro estoque de $\mathrm{Ni}$ acumulado pode ser remobilizado pela retomada da erosão, me 1horando assim as concentrações.

Em Santa $F \ddot{e}$, todas essas condições são mais ou menos preenchidas e o peso relativo de cada uma delas se rä examinado a seguir.

\section{RECONSTITUIÇAO HISTORICA DOS EVENTOS}

No Cretāceo Superior, em consequëncia da rea tivação Wealdeniana, ocorreram, por toda a borda da bacia do Paranā, intrusões de natureza ultrabāsico-alcalina, entre as quais a de Santa Fé.

Este corpo,predominantemente duntico, diferenciado nas bordas em wehrlito e alcalinas, ao ser levado a niveis mais superficiais da crosta, sofreu serpentiniza ção, transformação mineralōgica tĩpica da retromorfose. Este processo transformou uma grande parte da olivina em serpen- 
tina, carbonatos, brucita e magnetita, e deve ter se dado com uma certa remoção de $\mathrm{Si}$ e Mg, em solução. Nesta ocasião, houve a primeira remobilização do $N i$, que, sempre substituindo o $\mathrm{Mg}$, passou do reticulo da olivina para o retĩculo da serpentina, e conservou nela aproximadamente 0 mesmo teor do $\mathrm{Ni}$ do mineral primärio $(0,3 \% \mathrm{NiO})$.

0 domo ultramäfico foi exumado quando da peneplanização generalizada ocorrida no continente, na fase de agradaçäo do ciclo sul-americano (Terciārio inferior).E impossivel reconstituir todos os mecanismos que intervie ram nesta ëpoca, mas parece provävel que dois fenómenos, cu ja cronologia não foi bem estabelecida, prevaleceram: a si licificação e a laterização.

Durante um periodo de certa estabilidade, quando o relevo jā estava bem aplainado, o intemperismo conduziu à formação de uma cobertura de alteração. Na base dos perfis sobre dunito, a rocha sofreu silicificação: em suas fraturas depositou-se a silica sob forma de quartzo e calcedōnia, ou associada ao $\mathrm{Mg}$ e ao $\mathrm{Ni}$, formando filossili catos da sērie pimelita-kerolita. Este processo pode ser atribuĩdo a um episōdio de clima mais seco, durante o Terciärio inferior.

Posteriormente, sob clima mais agressivo, ocorreu laterizaçăo generalizada e, na parte superior do perfil lateritico então formado, o $\mathrm{Ni}$ concentrou-se residualmente por evacuação intensa do Si e Mg; assim tambēm se comportaram os demais elementos pouco soluveis ou insoTüveis, $\mathrm{Fe}, \mathrm{Cr}, \mathrm{Co}, \mathrm{Mn}$ e Cu.

Um novo levantamento do continente, por arqueamento, no Terciärio superior, trouxe como consequëncia a retomada da erosão (ciclo Velhas). A superficie Sul-americana foi sendo desmantelada e entalhada, mais profundamente onde a silicificação era menos intensa ou inexisten- 
te. Resultou daí a formação de relevos sustentados pela ca mada de sillica mais resistente, em contraste com as regiões de baixada, onde se acumularam os produtos laterizados dos antigos perfis.

Assim, quando, no Quaternärio inferior, a fase de agradação do ciclo velhas elaborou uma nova super ficie de aplainamento, uma parte do maciço escapou ao nivé lamento e permaneceu como relevo-testemunho.

A partir desta época, a superficie Velhas vem sofrendo meteorização, sob a ação de um clima tropical de estações contrastadas. 0 fato de haver alternāncia entre perĩodos mais secos e mais umidos impede a destruição brutal dos minerais hipögenos, permitindo a permanēncia transitöria de um horizonte silicatado, composto essencial mente por serpentina, na base do perfil.

A evolução se dä, no inĩcio, pela dissolução da olivina e precipitação, nas fissuras e descontinuidades da rocha quase fresca, de $\mathrm{Si}$ como quartzo e calcedōnia, ou associado ao $\mathrm{Mg}$ e $\mathrm{Ni}$ como "talco" hidratado, num processo semelhante ao que aconteceu durante a fase mais seca do ciclo sul-americano, mas com muito menor intensida de. A hidrölise incongruente da olivina deixa como residuo uma massa amorfa constituida por si e Fe. A serpentina,ain da não atacada, ē recoberta por uma película ferruginosa riginada pelo $\mathrm{Fe}$ liberado da olivina. O pH reinante na base do perfil $\vec{e}$ alcalino, o que propicia a precipitação do $\mathrm{Ni}$ como hidrōxido mal cristalizado.

Com o aumento da porosidade, a drenagem tor na-se mais eficiente e a alteração prossegue, acabando por dissolver a serpentina e dessilicificar os amorfos silico ferruginosos, Tiberando novamente o Ni. Neste estāgio, hä evacuação praticamente completa de Si e Mg, restando apenas o quartzo formado no inicio. O Fe permanece no perfil, 
assim como os demais elementos pouco solüveis ou insolüveis: $\mathrm{Cr}, \mathrm{Co}, \mathrm{Mn}, \mathrm{Al}$ e Cu. A goethita cristaliza-se e, em seu retículo, ē capaz de abrigar uma certa quantidade de $A 1, C r$ e Ni. O termo ültimo da evolução ē a hematita, com nova liberação do Ni.

Se a rocha-mãe for portadora de piroxēnio, quando da alteração, forma-se uma fase silicatada transitoria, representada pela nontronita, que ē capaz de abrigar um pouco de $\mathrm{Ni}$ em sua estrutura. Com o decorrer do proces so, a nontronita $\bar{e}$, por sua vez, destruĩda, e o Fe 1 iberado cristaliza-se na forma de goethita e hematita. Como o meio é mais rico em Al que no caso dos dunitos, pode haver formação incipiente de boehmita.

Nas encostas e sopēs, o processo é essencial mente o mesmo, mas, nesses sitios, principalmente nos primeiros, a erosão prevalece sobre a alteração e o perfil não se desenvolve. No topo, a camada silicificada protege a rocha subjacente da ação intempērica e erosiva.

Durante o ciclo Velhas, os elementos möveis, $\mathrm{Si}, \mathrm{Mg}$ e $\mathrm{Ni}$, foram mobilizados quimicamente em direção às baixadas. $0 \mathrm{Si}$ e o $\mathrm{Mg}$ sofreram evacuação continua, e foram drenados para fora do maciço. $0 \mathrm{Ni}$, ao conträrio, dissolvido em āguas que percolaram os perfis em vias de formação, mais intensamente nas suas zonas mais porosas e mais demora damente nas regiões de relevo plano, ficou parcialmente retido no reticulo da goethita, enriquecendo mais ainda este mineral. A nontronita pôde tambēm, eventualmente, reter uma parcela do $\mathrm{Ni}$ descendente, e chegar a teores interessante e conomicamente. Esse processo foi mais eficiente nas baixadas, mas ocorreu tambëm nos sopës e nas encostas.

A erosão dos antigos perfis sul-americanos trouxe para as baixadas as lateritas formadas durante a pri meira fase de aplainamento. Esse material, composto essen 
cialmente por $\mathrm{Fe}$ e demais constituintes menos möveis, entre os quais o $\mathrm{Ni}$, sofreu lixiviação, resultando, por aporte vertical, num enriquecimento desse elemento nas camadas subjacentes. Assim como no caso das äguas de movimento lateral, estas percolam com mais facilidade as zonas mais po rosas de laterita ferruginosa, contribuindo principalmente para a formação de goethita niquelifera. 
CAPITULO IV

IMPORTANCIA ECONŌMICA DA JAZIDA DE SANTA FE E COMPARAÇAO COM OUTRAS JAZIDAS DO MUNDO

\section{A Jazida de Santa Fé}

Em vista do exposto no capitulo precedente, fica claro porque são os sopés e, principalmente, as baixa das desenvolvidas sobre o nücleo de dunito serpentinizado, as zonas de maior interesse mineiro em Santa $F \bar{e}$. Barbour 1978, mostrou que tão somente $10 \%$ das äreas mineralizadas encontram-se sobre peridotito e apenas 1\% sobre piroxenito.

A partir do estudo de tres topossequencias (XV, E6 e parte da XXVII), pode-se afirmar que são tres os horizontes enriquecidos:

- saprolito grosso, com espessura entre 2 e $4 \mathrm{~m}$ e teores entre 0,4 e $1,6 \% \mathrm{Ni}$;

- Taterita amarela, variando de 0 a $2 \mathrm{~m}$ de espessura, com teores entre 0,7 e $2,1 \% \mathrm{Ni}$;

- laterita vermelha, de 1 a $4 \mathrm{~m}$ de espessura, com teores de 0,4 a $1 \% \mathrm{Ni}$.

Os dois primeiros horizontes constituem minērio, jā que o limite de explorabilidade para jazidas des se tipo está em torno de $1 \% \mathrm{Ni}$. A laterita vermelha como um todo não se apresenta muito interessante economicamente. Entretanto, como sua parte basal é enriquecida em relação a sua parte superior, a remoçâo de um capeamento estēril de cerca de $2 m$ de espessura, permite que tambëm este hori 
zonte seja explorado como minērio.

A figura 40 , que mostra a composição das amostras com mais de $1 \% \mathrm{Ni}$, em termos de seus principais cons tituintes, $\mathrm{SiO}_{2}, \mathrm{MgO}$ e $\mathrm{Fe}_{2} \mathrm{O}_{3}$, indica que o minērio apresenta gradação continua entre o polo silicatado e o polo oxidado. Indica ainda que os dois polos têm pesos equivalentes, e que nenhum deles ē privilegiado com relação aos maiores teores de $\mathrm{Ni}$ encontrados.

Esses dados concordam com os apresentados por Barbour 1978, segundo os quais cerca da metade do minērio ē tipo silicatado e metade do tipo oxidado. Ainda segundo este autor, a partir de dados coletados sobre toda a ärea do maciço, a espessura mëdia da camada mineralizada ē de cerca de $3 \mathrm{~m}$ e a relação estēril/minērio ē de $1 / 1$.

Para avaliação das reservas de minērio de $\mathrm{Ni}$ de Santa Fë, considerou-se:

- uma ārea de aproximadamente $15 \mathrm{~km}^{2}$ sobre dunito $+10 \%$ correspondendo ao peridotito

- espessura média da camada mineralizada como sendo de $3 \mathrm{~m}$

- densidade mëdia do minërio como 1,3

0 cälculo fornece um valor de $64 \times 10^{6}$ ton, não muito longe do que consta do relatörio do Ministērio das Mi nas e Energia 1978, que atribui a Santa Fë 61.10 ${ }^{6}$ ton de minerio como reservas provada e provāvel.

\section{Comparaçäo com Outras Jazidas de Niquel}

Distinguem-se, classicamente, dois tipos de 


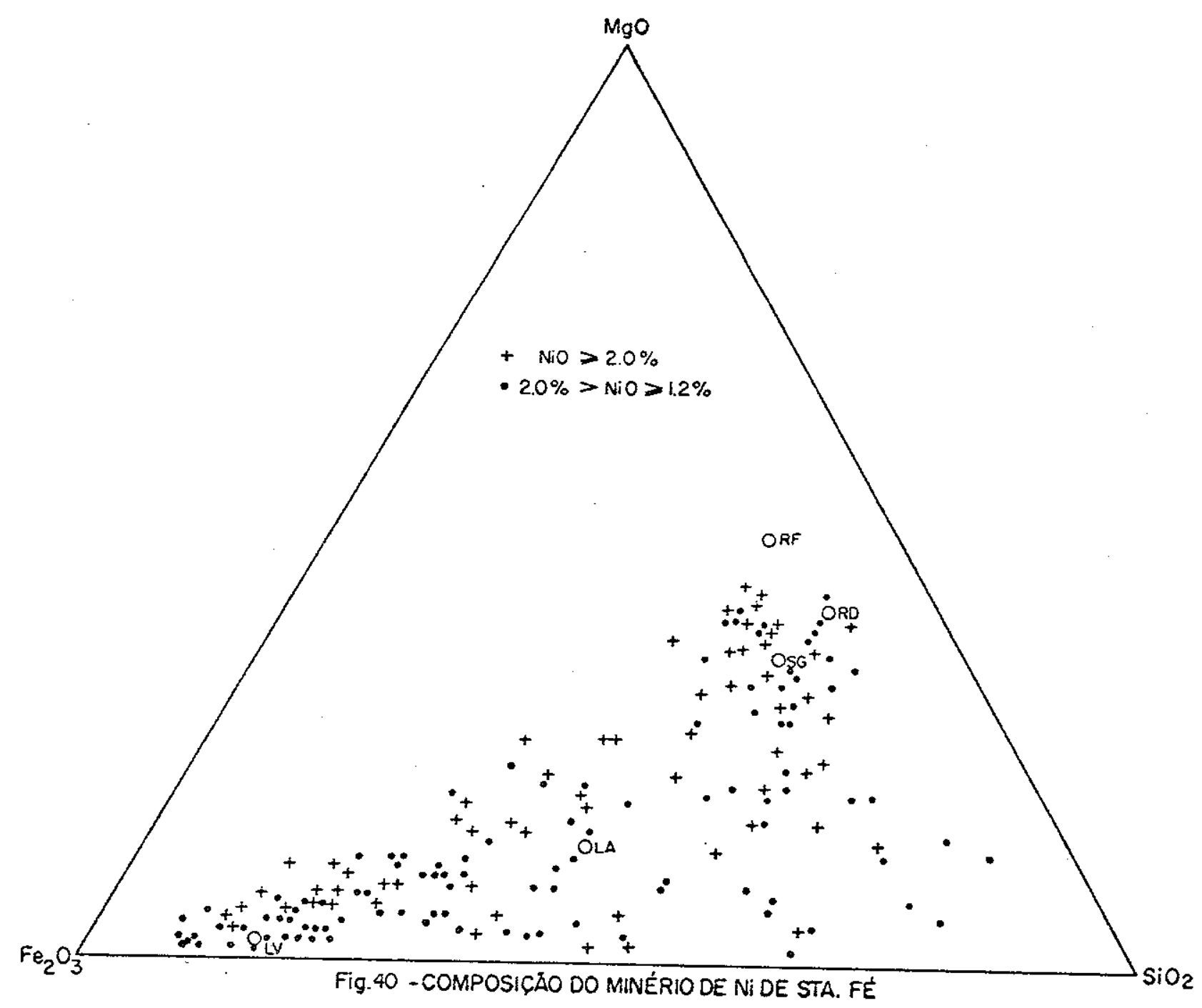


acumulaçăo de $\mathrm{Ni}$, segundo as condições de formação (Lombard 1956 e Avias 1972):

- jazidas sulfetadas de origem hipōgena, geneticamente relacionadas a intrusões noriticas, peridotiticas, ou a veios hidrotermais;

- jazidas laterīticas de origem supērgena, re sultantes da alteração intempērica de rochas ultrabäsicas, sob influência de clima tropical.

A jazida de Santa $F \bar{e}$, sendo do segundo tipo, serä comparada com suas congēneres no Brasil e no mundo.

\section{A. As Jazidas Brasileiras}

No Brasil, são conhecidas lateritas niqueliferas de interesse econōmico principalmente no estado de Goiās (Godoy 1968, Vasconcellos et al. 1973, Andrade $\xi$ Botelho 1974, Berbert 1977 e 1978): Niquelāndia (Pecora 1944, Pecora $\xi$ Barbosa 1944, Araujo et al. 1972, Barbosa 1968, Cos ta 1970, Schmaltz et al. 1976), Barro Alto (Figueiredo et al. 1972 e 1975, Melfi 1974, Souza 1973, Stache 1974), Santa Fë (Barbour 1976, Lessa Sobrinho et az. 1971, Lages et al. 1975), Serra Agua Branca (Lages et al. 1975, Justo 1973), Mor ro do Engenho (Chaban 1973, Lages et al. 1975) e alguns outros maciços menores e menos conhecidos. Em Minas Gerais, es tão as ūnicas jazidas que foram exploradas atē hoje: os pequenos maciços de Morro do Nìquel (Griffon $\xi$ Richter 1976 , Langer 1969, Santivanez 1961, Trescases $\xi 01$ iveira 1978), Li berdade e Ipanema (Ferran 1974, Lages et al. 1975 e 1976 , Esson $\xi$ Santos 1978).

Alēm destas jazidas, situadas todas em região de clima tropical de estações contrastadas, encontramse outras ocorrëncias de $\mathrm{Ni}$ laterítico em clima semi-ärido: 
São João do Piauí (Santos 1974), Serra das Marrecas no estado da Bahia (Bruni et al. 1976) e Catingueira na Paraíba (Farina 1969).

Em regiões mais ümidas, podem ser citadas as jazidas de Jacupiranga em São Paulo (Felicíssimo 1968, Ferran 1974) e as jazidas de Quatipuru (Cordeiro e McCandless 1976) e São Fēlix do Xingu (Lages et al. 1976), recentemente descobertas na Amazōnia e muito mal conhecidas.

Um esquema geral de compreensão da gēnese das jazidas niquelíferas brasileiras foi proposto por Mel $f i$ et al. em 1979. Segundo esses autores, o caräter comum a todas elas ē desenvolverem-se sobre rochas ultrabāsicas que sofreram duas fases de aplainamento, sul-americana e Vethas.

Durante a primeira fase, sob a influência de um clima semi-ārido, a alteração intempērica levou à formação, na base dos perfis, de um nivel silicificado. A evolução do clima para condições mais ūmidas provocou a la terização desses perfis, com uma primeira concentração residual de $\mathrm{Ni}$. Esses mecanismos tiveram atuação generalizada sobre toda a plataforma brasileira, o que explica a pre sença constante de produtos da silicificação nos perfis. Pa rece apenas não terem atuado ao sul da latitude 250̣, 1 imi te de ocorrência de crostas silicificadas sobre rochas ultrabāsicas e de jazidas lateriticas de $\mathrm{Ni}$.

No Terciärio superior, um novo ciclo erosivo começou, desmantelando a antiga superfície, da qual puderam resistir as rochas ultrabāsicas protegidas pela cama da silicificada. A partir de então, atē hoje, a alteração prossegue, tendendo à laterização e consequente acumulação relativa de $\mathrm{Ni}$, nas regiões de clima tropical de estações contrastadas, e a uma evolução do tipo esmectïtica nas regiões semi-āridas. No atual periodo erosivo, os morros tes 
temunhos da superfĩcie SuT-americana vão desaparecendo. Nas regiões de clima tropical, como em Goiäs, o Ni vai sendo transferido das regiões altas para as baixas, enriquecendo mais ainda os novos perfis. Em regiões semi-äricias, alguns maciços jă foram mais ou menos arrasados pela erosão ( Cati gueira na Paraíba e Andorinha na Bahia). Outros, como São João do Piauĩ, formam jazidas por enriquecimento de $\mathrm{Ni}$ trazido pelas soluções descendentes, que percolaram os perfis enriquecidos na primeira fase de aplainamento. Esse $\mathrm{Ni}$ foi aprisionado pelas esmectitas desenvolvidas sobretudo nas franjas de piedmont que circundam o maciço.

Em ambos os casos, o minério ē predominantemente silicātico, e encontra-se principalmente nas partes baixas do relevo; as dimensões e teores das jazidas não são muito grandes. Isto ê consequéncia de o clima não ser mais suficientemente agressivo, como no Nordeste, ou do fato de a Taterização não ter atuado por tempo suficiente (Goiàs).

Dentro desse quadro, a jazida de Santa Fé si tua-se entre as que sofreram duas fases de laterização, ou seja, as jazidas de Goiás e as de Minas Gerais.

0 perfil de alteração tĩpico de Santa Fè, de senvolvido sobre os dunitos serpentinizados da superficie Velhas $\vec{e}$, de modo geral, semelhante aos perfis de baixada em Niquelândia, sendo a única diferença marcante a maior es pessura do horizonte de laterita amarela em Santa Fē. Sobre rochas portadoras de piroxênio, tanto em Santa Fë como em Barro Alto ou Niquelāndia, os perfis são mais espessos, for mados principalmente por um saprolito fino de natureza nontronitica e não costumam apresentar silicificação. Em Santa $\mathrm{Fe}$, em geral, não são significativamente enriquecidos em $\mathrm{Ni}, j \bar{a}$ que a rocha de partida possui teor muito baixo neste elemento. Em Niquelândia, ao contrārio, a nontronita pode chegar a possuir teores de Ni atë 4\% (Bosio et az.1975). 
Isso se explica pelo fato de os perfis se desenvolverem sobre piroxenitos que ocupam fundos de vales suspensos, borde jados por cristas duniticas, permitindo, assim, que o sapro lito esmectitico aprisione o $\mathrm{Ni}$ trazido pelas soluções descendentes que o lixiviaram dos dunitos.

Com relação às zonas altas, em Santa Fë não existe nada de comparāvel ao perfil de Morro do Nĩquel ou aos perfis de platō, em Barro Alto e Niqueländia. Nestas jazidas, por debaixo da crosta silicificada, muito espessa em Morro do Niquel e menos espessa em Niqueländia e Barro Alto, encontra-se um perfil de alteração predominantemente si Ticatado, com desenvolvimento incipiente ou mesmo inexisten te de um horizonte de saprolito fino. Em Santa Fè, ao conträrio, nos topos dos morrotes quase não hä mais indīcios de silicificação e, em geral, aflora a rocha quase fresca, recoberta diretamente por alguns decimetros de laterita ver melha.

As semelhanças e diferenças apontadas podem ser explicadas, considerando que santa Fé, tendo conhecido $\underline{u}$ ma evolução essencialmente idëntica à dos outros maciços, encontra-se em um estagio de erosão mais avançado. Assim,os topos com alteraçöes relacionadas às duas fases de lateriza ção jä foram bem erodidos e rebaixados, e as baixadas ocupam a maior parte da ärea do maciço.

Tanto em Santa $F \vec{e}$ como nas outras jazidas, trēs horizontes constituem o minërio de $\mathrm{Ni}$ : saprolito grosso, saprolito fino (laterita amarela) e laterita vermelha.0 primeiro é tipicamente silicatado, com teores mëdios de 1 a $2 \%$ de $\mathrm{Ni}$. 0 terceiro ë oxidado com baixos teores (1\%) e 0 saprolito fino, transiçäo entre os dois tipos acima mencionados, possui os teores mais elevados, embora com espessuras sempre muito limitadas. Em termos de reservas, o tipo silicatado è mais importante. 
Em Barro Alto (Andrade $\xi$ Botelho 1974) minērio silicatado representa cerca de $70 \%$ das reservas, restando $20 \%$ para o saprolito fino e $10 \%$ para o minērio oxidado. Em Niquelāndia (Berbert 1978), a espessura do minērio oxidado è variāvel entre 1 e $5 \mathrm{~m}$ e seu teor mëdio $\vec{e}$ de $1 \%$, enquanto que o silicatado apresenta espessura media de $15 \mathrm{~m}$, com teores de 1 a $4 \%$, podendo chegar atē $20 \% .0$ caso extremo é representado por Morro do Niquel, onde todo - perfil é essencialmente silicatado (Trescases $\xi 01$ iveira $1978)$.

A jazida de Santa $F \vec{e}$ parece ser a mais late rizada entre as jazidas brasileiras. E a ünica que possui um horizonte de saprolito fino relativamente desenvolvido e, como consequência da intensa erosão que sofreu, apresen ta suas extensas baixadas recobertas por um manto laterit co,remobilizado a partir dos antigos perfis de topo e enri quecido em nĩquel. A figura 40 mostra que o minērio de niquel apresenta, em termos dos três elementos mais abundantes (ferro, silīcio e magnēsio), uma composição que varia desde a rocha pouco alterada ate a laterita vermelha, numa gradação contĩnua entre o polo silicatado e o polo oxidado.

Em resumo, Santa $\mathrm{Fe}$ representa um extremo e volutivo com relação às demais jazidas brasileiras desen volvidas sobre rochas ultrabäsicas, intemperizadas em condições de clima tropical. E, entre elas, a que se encontra em estägio de erosão mais avançado, talvez porque sua capa protetora silicosa tivesse sido menos espessa que nas ou tras jazidas. Em consequencia, suas planicies são mais desenvolvidas e os perfis de alteração a i formados são mais laterizados, por terem começado a evoluir mais cedo. Ainda em consequéncia da erosão, suas baixadas são recobertas por lateritas coluvionares.

Erosão e laterização săo, no caso, fatores que convergem no sentido de um major enriquecimento em $n \vec{i}-$ 
que 1.

Desde o pleistoceno, um novo ciclo erosivo vem entalhando a superficie Velhas, desmantelando as crostas ferruginosas que a recobrem prōximo aos cursos d'ägua. A travēs deste estudo, não foi possivel determinar se a tendência atual $\vec{e}$ da alteração prevalecer sobre a erosão (es pessamento dos horizontes de alteração) ou vice versa (destruição da jazida).

Com reserva estimada de $61.10^{6}$ ton de mine-rio de teor mëdio de $1,5 \%$, Santa $F \vec{e}$ coloca-se entre as prin cipais jazidas do Brasil (tabela 26), que ocupa o sētimo 1u gar no mundo em reservas de minērio de niqquel, com $4.10^{6}$ ton de niquel (Lages et al. 1975 e 1976).

B. Jazidas no Resto do Mundo

São conhecidas reservas laterïticas de $\mathrm{Ni}$ principalmente em regiões de clima tropical ou sub-tropical. No continente americano, alëm das brasileiras, destacam-se as de Cuba (de Vletter 1955), Venezuela (Jurcovic 1963) e Porto Rico (Schellmann 1976). Na Africa, foram descritas as ocorrências de Etiōpia (Clark 1978). Africa do Sul (De Wal 1971) e Madagascar (Schel1mann 1976). Distribuidas pelas iThas do oceano Pacifico, a literatura refere as reservas das Filipinas (Santos-Ynigo 1964, Santos-Ynigo $\xi$ Esguerra 1961), Nova Caledonia (Lacroix 1943, de Chetelat 1947, Trescases 1975), Bornēu(Schellmann 1964, Eswaran $\xi$ Sys 1972), Nova Gui nē (Bonifas $\xi$ Millot 1955, Percival 1964, Davies 1969) e Aus trälia (Zeissink 1969 e 1971).

Entre as lateritas niqueliferas antigas, que hoje ocorrem em clima temperado, podem ser citadas as do oeste dos Estados Unidos (Hotz 1964, Pecora $\xi$ Hobbs 1942, Pe cora et al. 1949), URSS (Betekhtine 1968, apud Trescases - 
AS JAZIDAS DE NIQUEL DO BRASIL (CPU⿺ MELFI et az.1979)

ESTAOO

JAZIOA
Niqueländia
Barro Alto
Carabrava
Santa Fe
Serra F̈gua Branca
Morro do Engenho
Morro dos Macacos
Pric dos Bois
Montes Claros (Saiobinha)
São Luis Montes Belos

Morro do Niquel

Minas Gerais

\section{Liberdade}

Ipanera

$\begin{array}{ll}\text { Săo Pauto } & \text { Jacupiranga } \\ \text { Piaui } & \text { Sāo joão do Piauí } \\ \text { Bahia } & \text { Serra das Marrecas } \\ \text { Parā } & \begin{array}{l}\text { São Felix do Xingu } \\ \text { Quatipuru } \\ \text { Carajas }\end{array}\end{array}$

TAMANHO APROXIMADO
DO MACICO ULTRABASICO
$100 \mathrm{~km}^{2}(39 \times 2,6 \mathrm{~km})$
$\left.45 \mathrm{~km}^{2}(24 \times], 9 \mathrm{~km}\right)$
$?$
$38 \mathrm{~km}^{2}$
$35 \mathrm{~km}^{2}$
$12 \mathrm{~km}^{2}$
$30 \mathrm{~km}^{2}$
$?$
$12 \mathrm{~km}^{2}$

$0,5 \mathrm{~km}^{2}$
$0,2 \mathrm{~km}^{2}$
$4 \mathrm{~km}^{2}$

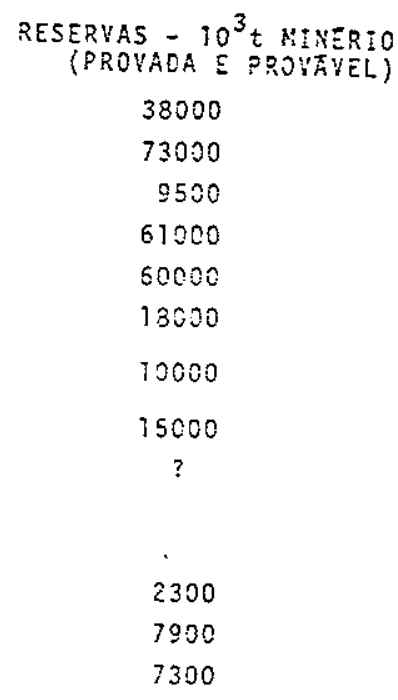

Fo:ites$$
+
$$

$\begin{array}{cc}1,7 & (1) \\ 1,7 & (1) \\ 1,24-1,59 & (1)\end{array}$

$$
6 \times m^{2}
$$

3200

1,47

$$
6 \mathrm{~km}^{2}
$$$$
?
$$$$
\text { ? }
$$$$
\begin{gathered}
90 \times m^{2} \\
?
\end{gathered}
$$

20000

1,57

900

1,5

13000 13000

(1) M.M.E. 1978

(2) LAGES et a. 1976

(5) BERBERT, C.o. H78 (Conferència no Instytuto de Geociencias de Rio claro)

(4) BRUx: et c2.1975

(5) CQROEZRO 5 MCCAMDLESS 1976 
1975, Grécia (Mossoulos 1964, Wilson 1972), Iugosiāvia (Ma ksimovic 1969), e Polónia (Wieviora 1978).

Do ponto de vista genētico, classificam- se os depösitos lateríticos de $\mathrm{Ni}$ em trēs tipos( Schellmann 1971):

- Tipo A: o enriquecimento em $N i$ ë relativo, determinado pela evacuação do $\mathrm{Si}$ e $\mathrm{Mg}$, de modo que os valo res de $\mathrm{Ni}$ acompanham os de $\mathrm{Fe}$ e o teor mäximo de $\mathrm{Ni}$ encontra-se na parte superior do perfil. Exemplo: Greenvale,Aus trāilia.

- Tipo B: hä enriquecimento absoluto em $\mathrm{Ni}$ por soluções descendentes e os maiores teores estão na laterita ferruginosa. Exemplo: Nonoc, nas Filipinas, Madagas car e Nova Guine.

- Tipo C: hã enriquecimento absoluto de $\mathrm{Ni}$ por soluções descendentes e os maiores teores estão na zona silicatada, ainda pouco alterada. Exemp10: Nova Caledōnia, Estados Unidos, Venezuela, Cuba, Brasil, e Bornēu.

A maior parte das ocorrências são mistas en tre $B$ e $C$, ora com predomináncia de um, ora de outro tipo. Em Nova Caledónia, por exemplo, ocorrem veios de garnierita e quartzo na base do perfil de alteração, e o horizonte de saprolito grosso é muito rico em $\mathrm{Ni}$. Mas, alēm deste fá cies que ē o ünico explorado atualmente, existe um espesso horizonte de saprolito fino, essencialmente ferruginoso, que constitui uma imensa reserva de mais baixo teor. Os de pósitos do oeste americano, principalmente o de Nickel Mountain no Oregon, são muito semelhantes aos da Nova Cale dônia. Como aqueles, estes contēm um horizonte silicáticó mais rico em $\mathrm{Ni}$ que as camadas sobrejacentes. Outros exemplos de depōsitos portadores de um horizonte silicatado de espessura significativa são os depósitos da Africa do Sur, 
Bornēu, Porto Rico, Etiōpia e os depōsitos brasileiros.

Contrastando com estes, outros depōsitos a presentam o horizonte de saprolito grosso, na base do perfil, pouco espesso ou mesmo praticamente inexistente. Assim, em alguns casos, apesar de os mais altos teores estarem nos fäcies silicatados, este $\bar{e}$ muito pouco desenvolvido e o minērio ë essencialmente do tipo oxidado, como na Venezuela e em Cuba.

Os depösitos da Iugosiāvia, Polônia, URSS e Grëcia são pouco evoluĩdos, apresentando apenas horizontes de alteração silicatados compostos por uma mistura de filossiticatos neoformados e herdados da rocha fresca.

A jazida de Santa $F \bar{e}$ apresenta caracterīsticas do tipo $B$ e $C$, em proporções mais ou menos equivalentes, resultando num minērio que vai desde uma fase sili catada atē uma fase oxidada, sem predominância de nenhuma delas. Em termos de espessura, com seus 3 ou $4 \mathrm{~m}$ de horizon te mineralizado, Santa $F \bar{e}$ não se compara com as grandes jazidas, como Nova Caledônia e Cuba (mais de $20 \mathrm{~m}$ de espes sura de minērio).

Atualmente, a produção de $\mathrm{Ni}$ a partir de mi nërios laterīticos contribui com apenas um terço da produ ção mundial de $\mathrm{Ni}$ e, dessa parcela, a metade vem da Nova Caledōnia (Lelong et al. 1976). No entanto, em termos de reservas, o minério laterïtico perfaz $85 \%$ da reserva de $\mathrm{Ni}$ do mundo (Schellmann 1971), constituindo, assim, promissoras fontes para o futuro. 
CONCLUSOES

No final deste trabalho, convēm ressaltar os principais resultados obtidos, bem como as liçöes mais importantes tiradas deste estudo.

1. Antes de serem expostas à superficie, as rochas ultramäficas de Santa $\overrightarrow{F e}$ sofreram serpentinização, que atingiu intensamente as olivinas: e muito discretamente os piroxēnios.

2. A rocha fresca ë constituida principalmen te por olivina magnesiana, serpentina, cromita e quantidades variāveis de clinopiroxēnio. E frequentemente cortada por veios de serpentina, brucita e carbonatos de $\mathrm{Mg} \mathrm{e} \mathrm{Ca.}$

3. A ordem de alteração supērgena dos silica tos ē olivina, piroxēnio e serpentina, reflexo da estabilidade crescente de suas estruturas cristalinas em meio super ficial.

4. A hidrölise incongruente da olivina deixa um residuo amorfo sijlico-ferruginoso que, posteriormente, volui em goethita. A partir da olivina, ocorre neoformação incipiente de esmectita, de natureza não determinada.

5. 0 piroxênio altera-se em nontronita que acaba sendo dissolvida, dando lugar à cristalizaçăo de goethita e de boehmita.

6. A serpentina sofre dissolução com evacua çăo completa de Si e Mg. O Fe nela contido evolui para goethita.

7. A cromita sofre dissoluçäo nas bordas. 
ferruginosos $\bar{e}$ a hematita.

8. 0 termo final da evolução dos produtos

9. Nos veios, a brucita e os carbonatos dis solvem-se prontamente; neles podem precipitar quartzo e calcedônia, associados ou não a filossilicatos do tipo"tal co" hidratado, com distancia interplanar de cerca de $10 \AA$.

10. Os minerais hipōgenos que permanecem nos horizontes mais alterados são cromita, magnetita e o inter estratificado vermiculita-clorita. Os neoformados são quartzo, goethita e hematita.

11. $0 \mathrm{Ni}$ encontra-se sob as seguintes formas :

- hidroxido precipitado nas descontinuidades da rocha alterada ou adsorvido às fibras de serpenti na;

sos;

- associado aos amorfos sîlico-ferrugino

- pimelita'("ta1co" $10 \AA$, niquelïfero);

- goethita.

12. A mobilidade relativa dos elementos pode ser assim escalonada:

$$
\mathrm{Ca}>\mathrm{Mg}>\mathrm{Si}>\mathrm{Ni}>\mathrm{Mn}>\mathrm{Co}, \mathrm{Fe}, \mathrm{Al}, \mathrm{Cr} \text {. }
$$

13. o cälculo isovolume, nos värios setores da topossequēncia, mostrou que:

tica;

- Si e Mg são evacuados da paisagem dunï

- Fe, Al, Cr e Co permanecem no perfil de alteração e podem apenas sofrer deslocamentos mecânicos; 
- Ni permanece, pelo menos em parte, na paisagem dunitica, devido a sua relativa solubilidade.

14. E necessäria a hipōtese de 2 perĩodos de laterização para explicar a gēnese da jazida. $0 \mathrm{Ni}$ sofreu uma prë-concentração no primeiro período; os produtos des se processo foram uma importante fonte de $\mathrm{Ni}$, durante a se gunda etapa de laterizaçăo.

15. O Ni contido na LV tem 2 origens:

- residual, a partir da alteração da LA;

- coluvionar, trazido na laterita sul-americana, erodida para as baixadas.

16. O Ni contido nos fäcies saprolïticos das baixadas e soma de 3 parcelas:

- Ni contido no material de origem;

- Ni trazido por aporte latera1, dissolvido nas āguas que o dissolveram dos antigos perfis a montante;

- Ni trazido por aporte vertical, a partir da laterita vermelha.

17. 0 minērio de $N i$ de Santa $F \vec{e}$ encontra- se em situação intermediāria entre polo oxidado e o polo si licatado.

18. As crostas silicificadas encontradas nos topos dos morrotes sáo vestígios do periodo Sul-americano de laterização. Fragmentos rolados delas são encontrados nas baixadas.

19. As crostas ferruginosas encontradas nas baixadas săo resultantes de um processo mais recente: ci- 
mentação dos ō̄litos e pisōlitos residuais e coluvionares nas regiões prōximas aos cursos d'ägua, sob influência das oscilaçöes do nïvel hidrostätico.

valecem:

20. Atualmente dois processos antagönicos pre

- aprofundamento dos perfis de alteração por laterização, sob clima tropical de estações contrastadas;

perfis de alteração.

- erosão e consequente destruição dos

As värias questões respondidas por este estu do, resumidas nos 20 itens acima, suscitaram outras tantas, que permanecem em aberto. Entre estas, as mais importantes dizem respeito a:

- detalhamento da repartição dos elementos quĩmicos nos minerais (a ser estudado por mëtodos analiticos mais refinados como, por exemplo, microssonda eletrōn ca ) ;

- equilibrios atuais (a serem investigados por meio do estudo termodināmico da fase solūvel da altera (̧ão);

- balanço atual da erosão $x$ intemperismo(tam bëm a ser investigado pelo estudo do material em soluçäo e em suspensão, nas äguas que drenam o maciço). 


\section{B I BL I OGRAF I A}

AB'SABER, A.N. $\xi$ COSTA JR, M. - 1948 - "0 sudoeste goiano" An. Ass. Geogr. Bras. III (I): 143-219.

ALMEIDA, F.F.M. de - 1948 - "Reconhecimento geomörfico nos planaltos divisores das bacias Amazōnica e do prata en tre os meridianos 510 e 560 W"-Rev. Bras. Geogr. ano $x, 3: 395-440$.

ALMEIDA, F.F.M. de - 1967 - "Observações sobre o prë-Cam briano na regiäo central de Goiäs"-XXI Congr. Bras. Geol., Bol. Paranaense de Geoc., 26:19-22.

ALMEIDA, F.F.M. de - 1971 - "Geochronological division of the precambrian of South America"-Rev. Bras. Geoc.1(1): 13-21.

ANDRADE, M.R. $\xi$.BOTELHO, L.C. - 1974 - "Perfil analitico do Nique1"-Bo1. DNPM-33-Rio de Janeiro $90 \mathrm{p}$.

ANGEIRAS, A.G. - 1968 - "A faixa de serpentinitos da região central de Goiäs"-An. Ac. Br. Cienc., 40: 129-136.

AVIAS, J. - 1978 - "L'èvolution des idēes et des connais sances sur la genèse et sur la nature des minerais de nickel, en particulier latëritiques, de leur dēcouverte à nos jours"- Bul1. BRGM., sect II, 3:165-172.

BARBOSA, A.L.M. - 1968 - "Ambiente geolögico das jazidas ni quelîferas de Niquelândia, GO."- Bol. SICEG. Ouro Preto, $6: 79-89$.

BARBOUR, A.P. - 1976 - "Geologia do maciço ultramāfico de Santa Fè (GO)" - Tese de Livre Docência IGUSP, 138 p. 
BARBOUR, A.P. - 1978 - "Maciço ultramäfico Ni-laterĩtico de Santa Fē, Goiäs, Brasil" - Apresentado no VII Congresso Geolögico Argentino - Neuquen (no prelo).

BARBOUR, A.P., GIRARDI, V.A.V., KAWASHITA, K. . SOUZA, A.M.S. de - 1979 - "Geocronologia do complexo māfico-ultramāfí co alcalino de Santa Fē, Goiās" - Bo1. IGUSP, 10:11-18.

BESSET, F. - 1978 - "Localisations et rēpartitions sucessives du nickel, au cours de l'altëration lateritique des péridotites de Nouvelle-Calëdonie" - Th.Un.Sc.Tech.Languedoc. Montpelijer. $129 \mathrm{p}$.

BESSET, F. $\xi$ COUDRAY, J. - 1978 - "Le comportement du nickel dans les processes d'altēration des pēridotites de Nouvelle calëdonie" - Bul1. BRGM,sect. II, 3: 207-223.

BERBERT, C.0. - 1970 - "Geologia geral dos complexos bās $\underline{i}$ cos e ultrabāsicos de Goiäs". An XXIV Congr. Br. Geol. Brasitia: $41-50$.

BERBERT, C.0. - 1977 - "Rochas bäsico-ultrabäsicas no Brasil e suas potencialidades econōmicas" - Bol.II SEG. Pa ranä- CEGEP-UF Paranä: 1-51.

BERBERT, C.0. - 1978 - "Depósitos de nĩquel do Brasil Centra 1." Aula proferida no I.G.UNESP (mimeografado).

BETEKHTINE, A. - 1968 - "Manuel de minēralogie descriptive":E ditions Mir-Moscou, 736p.

BLOT, A., LEPRUN, J.C. G PION, J.C. - 1976 - "Action de 1" altēration mētēorique sur le complexe ultrabasique de Koussane (Sënëgal oriental). Les diverses accumulations et migrations de matiēre"-Bul1. Soc. Geol.France, XVIII (1): $51-54$. 
BLOT, A., CARN, M., LEPRUN, J.C. G PION, J.C. - 1976 - "Pre mier bilan des ētudes gëlogiques et pëdologiques d'un corps ultrabasique et de son contexte: Koussane au Sēnēgal Oriental"-Cah. Orstom, sēr.Gēologie,VIII (2): $113-145$.

BONIFAS, M. $\xi$ MILLOT, G. - 1955 - "Transformation isovolumëtrique dans les phēnomènes de latērisation et de bauxitisation" - Bull.Serv. Cart. Geol. Als.Lorr., 8, (1): 3-20.

BONIFAS, M. - 1959 - "Contribution à 1'ëtude gëochimique de altëration latēritique" - Mem.Serv. Cart. Geol. Als. Lorr., Strasbourg, $17,159 \mathrm{p}$.

BOSI0, N.J., HURST, V.J. G SMITH, R.L. - 1975 - "Nickeliferous nontronite, a $15 \&$ garnierite, at Niquelāndia, Goiās, Brasil" - Clay Miner. Bull, 23: 400-403.

BRAUN, 0.P.G. - 1971 - "Contribuição à geomorfologia do Brasil Central"- Rev. Bras. Geogr. ano XXXII, 3:3-40.

BRINDLEY, G.W. $\xi$ HANG, P.T. - 1973 - "The nature of garnie rites - I. Structures, chemical composition and color characteristics"- Clay and Clay Min. 21:27-40.

BRINDLEY, G.W. $\xi$ MAKSIMOVIC, Z. - 1974 - "The nature and nomenclature of hydrous $\mathrm{Ni}$-containing silicates" -Clay minerals, 10: 271-277.

BRINDLEY, G.W. - 1978 - "The structure and chemistry of hy drous nickel-containing silicate and aluminate minerals" - Bu11. BRGM, sect II, 3: 233-245.

BROOKS, R.R. - 1972 - "Geobotany and biogeochemistry in mi neral exploration"- Harper and Row Publishers, New York, $299 \mathrm{p}$. 
BROWN, G. - 1961 - "The X-ray identification and crystal structures of clay minerals"- Mineralogical Society. London, $544 \mathrm{p}$.

BRUNI, M.A.L. - 1976 - "Carta geolögica do Brasil ao milionësimo. Folha Aracaju (SC-24)", 226 p. DNPM. Brasīia.

CAILLERE, S., HENIN, S. G ESqueVIN, J. - 1956 - "Etude expërimentale du mëcanisme de la formation des antigori tes nickëliféres"- Soc. Fr.Min.Crist. Bull.,79 (7-9): $408-420$.

CERRI, C.C. - 1974 - "Contribuição ao estudo das arenas graniticas"- Tese de Mestrado IGUSP, $130 \mathrm{p}$.

CHABAN, N. G SANTOS, J.F.dos - 1973 - "Intrusiva do Morro do Engenho (GO): consideraçöes sobre geologia e pesquisa" - XXVII Congr. Br. Geo1. Aracaju - Resumos 1: $57-58$.

CHANTRET, F., DESPRAIRIES, A., DOUILLET, P., JACOB, C., STEINBERG, M. $\xi$ TRAUTH, N. - 1971 - "Rëvision critique de l'utilisation des méthodes thermiques en sëdimento logie: cas des smectites (montmorillonites)"- Bull. Groupe Franç. Argiles, XXIII: 141-172.

CHAYES, F. - 1960 - "On correlation between variables of constant sum" - J. Geophys. Res. 65: 4185-4193.

CHETELAT, E.de - 1947 - "La genēse et 1'ēvolution des gisements de $\mathrm{Ni}$ de la Nouvelle Calëdonie"-Soc.Geol. Fr. Bu11. sērie 5, 17: 105-159.

CLARK, A.M.S. - 1978 - "Chemical and mineralogical develop ment of the Sidamo nickeliferous serpentinites(Ethio pia)"- Miner.Deposita, 13 (2): 221-234. 


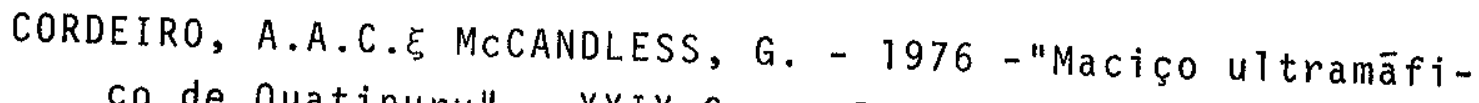
co de Quatipuru" - XXIX Congr.Bras.Geol. Ouro Preto- Re
sumos: 238 .

Costa, J.L.G. - 1970 - "Jazidas de Niquel do maciço de São Jose do Tocantins - Notas sobre a geologia econômica e pesquisas pela Cia. Nĩquel Tocantins".- XXIV Congr.Bras. Geol. Brasilia - Bol. Esp. 1: 140-141.

DANNI, J.C.M. - 1974 - "Gëologie des complexes ultrabasiques alcalins de la rëgion d'Iporä, Goiäs, Brēsil". Tese Universidade de Paris-Sud, $95 \mathrm{p}$.

DAVIES, H. L. - 1969 - "Notes on Papuan Ultramafic Belt Mineral Prospects. Papua \& New Guinea"-- Record nọ 1969/ 67. Bureau of Min. Res. Geol. and Geophysics. Austrälia $20 \mathrm{p}$.

DEER, W.A., HOWIE, R.A. $\xi$ ZUSSMAN, 4. - 1963 - "Rock forming minerals"- 5 volumes - Longmans-Londres.

DE KIMPE, C.R. $\xi$ ZIZKA, J. - 1973 - "Weathering and clay formation in a dunite deposit at Asbestos" - Can J.Earth Sci, 10, (10): 1533-1540.

DELMAS, A.B. - 1972 - "Sur les rôles respectifs de la tempē rature et du dēbit au cours de l'altēration expērimenta le de T'olivine par lessivage a l'eau" - C.R. AC. SC.Pa ris, 274: $2413-2415$.

DE VLETTER, D.R. - 1955 - "How Cuban ore was formed: a lesson in lateritic genesis" - Eng. and Min. Jaurnal, 156 (10): $84-87$.

DE WAAL, S.A. - 1971 - "South African nickeliferous serpentinites" - Miner. Sc. Engeneering, Pretoria 3 (2): 32 45. 
EDEL'SHTEIN, I.I. - 1960 - "The geochemistry of nickel"-Geo chemistry, $1:$ 718-729.

ESSON, J. E SANTOS, L.C.S.dos - 1978 - "Chemistry and minera logy of section through lateritic nickel deposit at Liberdade, Brasil"- Instn. Min. Metall.,sect.B,Appl.Earth Sc., $87 \mathrm{p}$. (in press).

ESSON, J. G SANTOS, L.C.S.dos - 1978 - "The occurrence, mineralogy and chemistry of some garnierites from Brazij" Bu11. BRGM, sect.II, 3: 263-274.

ESWARAN, H. $\xi$ SYS, C. - 1972 - "Clay mineralogy of soils on ultrabasic rocks from Sabah, Borneo" - Int. Clay.Conf., Madrid, I: 125-225.

FARINA, M. - 1969 - "Ultrabasitos niqueliferos de Catinguei ra, Paraíba. Considerações sobre a geoquĩmica e geologia económica". - Bol. SUDENE, Depto.Rec.Nat., sērie Geo logia Econômica, 7, 53 p.

FAUST, G.T. - 1966 - "The hydrous nickel-magnesium silica tes-The garnierite group" - The American Mineralogist, $51,(3): 279-298$.

FELICISSIMO Jr.,J. - 1968 - "Distritos ultrabäsicos-alcä7icos da bacia tectónica do baixo Ribeira e seus aspectos econômicös." - Bol. SICEG-0uro Preto - 6: 90-134.

FERRAN, A.de - 1974 - "Panorama do Ni no Brasil"- Geol. e Met., IV Simp. Mineração, 1a. parte, 35: 103-124.

FRITZ, B. $\xi$ TARDY, Y. - 1973 - "Etude thermodynamique du sy $\underline{s}$ tème gibbsite, quartz, kaolinite, gas carbonique. Appli cations à la genēse des podzols et des bauxites" - Sc. Gēol. Bu11.,4: 339-367. 
GALVAO, M.V. - 1960 - "Geografia do Brasi1. Grande Região Cen tro-oeste". IBGE vol. II sērie A. Rio de Janeiro, 452 p.

GODOY, A.C. - 1968 - "Mapa das ocorrēncias minerais do Estado de Goiăs, com a localização dos principais maciços bāsicos elou ultrabāsicos".- An. XXII Congr.Bras.Geo1., Belo Horizonte: $223-229$.

GRIFFON, J.C. $\xi$ RICHTER, H. - 1976 - "Geologia, mineração e tratamento do minério de níquel do Morro do Niquel -MG". Geo1. Met., VII Simp. Br. Mineração, 4: 387-405.

GUIMARAES, D., GLASER, I. G MARQUES, V.J. - 1968 - "Sobre a ocorrēncia de rochas alcalinas na região de Iporä, GO" Min. Met., 48 (283): 11-15.

HANG, P.T. $\xi$ BRINDLEY, G.W. - 1973 - "The nature of garnier $\underline{i}$ tes III - Thermal transformations" - Clay and Clay Min., $21: 51-57$.

HENIN, S. $\xi$ ROBICHET, 0. - 1953 - "Sur les conditions de formation des minéraux argileux par voie expērimentale à basse tempērature"-- C.R.AC.SC. Paris.,236: 517-519.

HENIN, S. छ CAILLËRE, S. - 1963 - "Synthēse des minēraux argi leux à basse tempērature: essai de mise au point."- clay Min. Bul1, 30: 265-271.

HOTZ, P.E. - 1964 - "Nickeliferous laterites in Southwestern. Oregon and Northwestern California".- Ec.Geology,59(3): $335-396$.

HYPOLITO, R. - 1972 - "Estudo experimental de alteração intem përica de diabásios". Tese de doutoramento-IGUSP, 103 p.

JURKOVIC, I. - 1963 - "Some geochemical aspects about the ge" nesis of the nickel deposit Loma de Hierro(Venezuela)!" Geoloski Vjesnik-17: 103-112. 
JUST0, L.J.E.C. - 1973 - "Maciço ultramäfico de Agua Branca, Goiās: um corpo tabular". XXVII Congr.Bras.Geo1. Aracaju. Resumos, 1: 56-57.

KING, L.C. - 1956 - "A geomorfologia do Brasil oriental". Rev. Br.Geogr., 2:147-265.

KRAUSKOPF, K.B. - 1956 - "Dissolution and precipitation of silica at low temperatures". Geoch.Cosm.Acta., 10:1-26.

KUHNEL, R.A., VAN HILTEN, D. छ ROORDA, H.J. - 1974 - " The cristallinity of minerals in alteration profiles: an example on goethite in laterite profiles". - Delft Pro gress Report. Series $E, I(1): 1-32$.

KUHNEL, R.A., ROORDA, H.J. G STEENSMA, J.J.S. - 1978 - "Dis tribution and partitioning of elements in nickeliferous laterites". BuT1. BRGM, Sect II, 3: 191-206.

LACROIX, A. - 1943 - "Les pēridotites de Nouvelle Calëdonie, leus serpentinites et leurs gites de $\mathrm{Ni}$ et de $\mathrm{Co}^{\prime \prime}$. AC. Sc. Mem. Paris.,66, 143 p.

LAGES, S.M., ANDRADE, M.R. G OLIVA, L.A. - 1976 - "Economia mineral do nĩquel". XXIX Congr. Br. Geol. Ouro Preto-Re sumos: $394-395$.

LELONG, F., TARDY, Y., GRANDIN, G., TRESCASES, J.J. $\xi$ BOULANGE, B. - 1976 - "Pedogenesis, chemical weathering and processes of formation of some supergene ore deposits". in"Handbook of strata-bound and stratiform deposits"R.H. WOLF edit. - Elsevier - Amsterdan.,3: 93-173.

LEPRUN, J.C. - 1979 - "Les cuirasses ferrugineuses des pays cristallins de l'Afrique occidentale sēche.Genèse. Trans formations. Dëgradations". Thèse U.L.P.- Strasbourg $222 p$. 
LEVI, F. $\xi$ MELFI, A.J. - 1972 - "Geochemical and mineralogical studies of the first stages of weathering of basic and related rocks. Part II - Geochemical study." Rev.Br. Geoc., 2(1): 1-7.

LESSA So, M., ANDRADE, R.S.de $\xi$ BERBERT, C.0. - 1971 -"Pro jeto Jussara - Geologia das quadrículas de Britânia, Santa Fé, Araguapaz e Jussara, Estado de Goiās"- DNPM (Executado pela CPRM), Goiānia - Inēdito.

LINDENMAYER, D.H. $\xi$ LINDENMAYER, Z.G. - 1971 - "Intrusõesultrabāsicas-alcalinas e suas mineralizações a nĩquel". An. XXV Congr.Bras.Geol. São Paulo - Bol.Esp., 1:35.

LOMBARD, J. - 1956 - "Sur 1 a gëochimie et les gisements de nickel". Chron.Min.d'Outre Mer, 244, $20 \mathrm{p}$.

LUCAS, J., CAMEZ, T. $\xi$ MILLOT, G. - 1959 - "Dëtermination pratique aux rayons $X$ des minëraux argileux simples et interstratifiēs". Bu11. Serv.Cart.Geol.A1s.Lorr.,12(2): 21-31.

LUCE, R.W., BARTLETT, R.W. G PARKS, G.A. - 1972 - "Dissolu tion kinetics of magnesium silicates".- Geoch. Cosm. Acta., 36(1): 35-50.

MACKENZIE, R.C. - 1957 - "The differential thermal investi gation of clays".- Mineralogical Society. London.456p.

MAKSIMOVIC, Z. - 1966 - "B-kerolite-pimelite series from Goles Mountain, Yugoslavia". Proc. Int. Clay. Conf., I: $97-105$.

MAKSIMOVIC, Z. - 1969 - "Nickeliferous minerals found in the fossil crust of weathering in Goles (Yugoslavia)". An. Geol. Pen. Balcanica, tomo XXXIV: 577-596. 
MARINI, 0.J., BARBOSA, G.V., DARDENNE, M.A., FARIA, A. $\xi$ FUCK, R.A. - 1974 - "Projeto Serra Dourada". - Un.Brasilia, Depto. Geoc., Convênio DNPM/FUB, 1(7). Relatōrio final inëdito.

MATHESON, J.D. - 1967 - "Notes on the formation and geological setting of chrysoprase in the Marlborough deposits" Queensland Govern. Mining Journal: 495-497.

MELFI, A.J. - 1971 - "Influência da sîlica na evolução dos geles amorfos de Fe ${ }^{I I}$ : estudo experimental simulando condições tropicais ümidas e bem drenadas". Tese de Livre Docência IGUSP, $90 \mathrm{p}$.

MELFI, A.J. G LEVI, F. - 1971 - "Geochemical and mineralogi cal studies of the first stages of weathering of basic and related rocks. Part I - Mineralogical study".Rev. Br. Geoc., 1(1): 22-28.

MELFI, A.J. - 1974 - "Caracteristicas geoquímicas e minera lögicas dos estädios iniciais de alteração superficial das rochas ultrabäsicas de Barro Alto (GO)".Bol.IGUSP, 5: 117-128.

MELFI, A.J., TRESCASES, J.J. $\xi$ OLIVEIRA, S.M.B.de - 1979 "Les "laterites" nickēlifēres du Brēsil". Apresentado no Int.Sem.on Lat. Processes. Trivandrum, India.

MILLER, R. - 1953 - " The Webster - Addie uttramafic ring, Jackson Country, North Carolina, and secondary alteration of its chromite". Am.Min. 38:1134-1147.

M.M.E. - 1978 - Ministērio das Minas e Energia da Repüblica Federativa do Brasil - Balanço Mineral Brasileiro"-Bra silia, $212 \mathrm{p}$.

MOREIRA, A.A.N. - 1977 - "Geografia do Brasil-Regiăo Centro0este"-Fund.IBGE, 4, 364 pp, Rio de Janeiro. 
MOSSOULOS, L. - 1964 - "Les gisements latēritiques de fer chromonickēlifëre de Grēce.Mëthodes de prospection de la chromite." OCDE, Paris.

NAHON, D. - 1979 - "Accumulation supergēne de quartz par altēration de roches ultrabasiques en Cóte d'Ivoire". Sc. Geol. vol.4 (in press).

NALOVIC, L. - 1971 - "Comportement du fer en présence des êlements de transition dans la nature". C.R.Ac.SC.Paris, 273: 1664-1667.

NALOVIC, L. G PINTA, M. - 1972 - "Comportement du fer en prēsence des ēlēments de transition. Etude expërimenta le: lessivage des hydroxydes hydratēs par de l'eau, à l'air libre". C.R.Ac.Sc.Paris, 275: 153-756.

NALOVIC, L. $\xi$ SEGALEN, P. - 1973 - "Relations entre le fer et les ēlëments traces de transition dans un certain nombre de minēraux ferrifēres". Cah. ORSTOM, sér. Pēdo logie, $X I$ (2): 181-191.

NORTON, S.A. - 1973 - "Laterite and Bauxite formation".-EC. Geo1. 68, (3): 353-361.

OLIVEIRA, S.M.B.de. $\xi$ MELFI, A.J. - 1979 - "Considerações sobre a origem das esmectitas nos niveis de alteração dos piroxenitos de Santa Fē (G0)".- Bol.IGUSP, 10:9196.

PECORA, W.T. $\xi$ HOBBS, S.W. - 1942 - "Ni deposit near Riddle, Douglas County, Oregon.USGS" Bu11.931-I: 205-226.

PECORA, W.T. G BARBOSA, A.L.M. - 1944 - "Jazidas de niquel e cobalto de São Josë do Tocantins, Estado de Goiās".-Bol. DNPM-DFPM, 64, $69 \mathrm{p}$. 
PECORA, W.T., HOBBS, S.W. E MURATA, K.J. - 1949 - "Varia tions in garnierite from the $N i$ deposit near Riddle, Oregon".- Ec.Geol., 44:12-23.

PEDRO, G. छ BITAR, K.E. - 1966 - "Contribution à l'étude de la genēse des sols hyper-magnēsiens: recherches expērimentales sur l'altēration chimique des roches ultrabasi ques (serpentinites)". Ann.Agron. Versailles, 17 (6). : $611-651$.

PEDRO, G. $\xi$ DELMAS, A.B. - 1971 - "Sur l'aliērātion expērimentale de l'olivine par lessivage à l'eau et la mise en ëvidence de trois grands domaines d'évolution gëoch $\underline{i}$ mique".- C.R.Ac. Sc. Paris, 273: 1543-1546.

PEDRO, G. $\xi$ DELMAS, A.B. - 1973 - "Roches ultrabasiques" in Encyclopaedia Universalis, 16: 453-457.

PENA, G.S. G Figueired0, A.J.de - 1973 - "Geologia da qua drīcula de Iporā (GO)" - XXVII Congr.Br.Geol. Aracaju. Resumos 1: 106-108.

PERCIVAL, F.G. - 1964 - "The lateritic iron deposit of Cona kry" - Trans. Inst. Min. Metallurgy, 74, part 8: 429462 .

PERRUCHOT, A. - 1971 - "Reproduction an laboratoire des phe nomēnes de concentration du nickel au cours de l'altéra

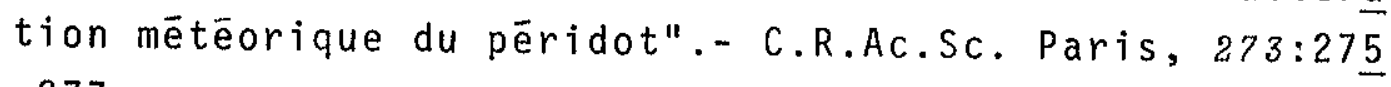
-277 .

PICKERING, R.J. - 1962 - "Some leaching experiments on three quartz-free silicate rocks and their contribution to an understanding of laterization".-Ec.Geol., 57:118 -1206 . 
PION, J.C. - 1979 - "L'altération des massifs cristallins ba siques en zone tropicale sēche. Etude de quelques topossēquences en Haute Volta".- Thèse U.L.P.- Strasbourg, $220 \mathrm{p}$.

ROBERT, M. $\xi$ TESSIER, D. - 1974 - "Mēthode de prēparation des argiles des sols pour des ētudes minëralogiques". Ann. Agr., 25 (6): 859-882.

ROSENBURG, J.P. - 1972 - "Estudo de vermiculitas brasileiras". Tese de Doutoramento IQUSP, $157 \mathrm{p}$.

ROSS, C.S. G EARL, V.S. - 1926 - "Nickeliferous vermiculite and serpentine, North Caroline". Am.Minera1, 11: 90-93.

ROSS, C.S., SHANNON, E.V. GONYER, F.A. - 1928 - "The origin of nickel silicates at Webster North Caroline". Ec. Geol., 23 (5): $528-552$.

SANTIVANEZ, A.0. - 1965 - "As serpentinitas niqueliferas do "Morro do Nīquel" em Pratāpolis, M.G."- Eng.Min.Met.,XLII (248): $61-65$.

SANTOS, J.F.dos - 1974 - "Fatores de controle na concentração do niquel lateritico condicionado pela evolução geolögica e geomorfolögica do complexo bäsico-ultrabāsico de são João do Piauĩ (PI)". An. XXVIII Congr.Br.Geol., 6: 25-32.

SANTOS-Y.,L. E ESGUERRA, F.D. - 1961 - "Gëologie et gëochimie des latērites nickelifēres de NONOC et Province de Surigao (Philippines)".- Philippines Bur. of Mines-Manille. Spec.Proj.Ser,Publ:18.

SANTOS-Y.,L. - 1964 - "Distribution of iron, alumina and sili ca in Pujada Laterite of Mati, Davao Province, Mindanao Island (Philippines)".- XXII Int.Geol. Congress New Delhi, sect. $14: 126-141$. 
SCHMALTZ, W.H., FIGUEIREDO, A.M.de छ CUNHA, C.A.B.R.-1976"Pesquisa de sulfetos de $\mathrm{CU}-\mathrm{Ni}$ no maciço de Niquelāndia." XXIX Congr.Br.Geo1. Ouro Preto. Resumo: 263.

SCHELLMANN, W. - 1964 - "Zur laterischen Verwitterung von Serpentinit". Geo1. Jb., 81: 645-678.

SCHELLMANN, W. - 1971 - "Uber Beziehungen lateritischer Ei sen-Nickel-Aluminium-und Manganerze zu ihren Ausgangsgesteinen".- Miner.Deposita, 6(4): 275-291.

SCHELLMANN, W. - 1976 - "Distribution, fixation and chemical mobilization of nickel in iron-rich lateritic nickel ores". Concluding Report. Federal Institute of Geosciences and Raw Materials. Unpublished Report.

SCHELLMANN, W. - 1978 - "Behavior of nickel, cobalt and chromium in ferruginous lateritic nickel ores".- Butl. BRGM, sect II, 3: 275-282.

SCHOBBENHAUS FILHO, C. - 1975 - "Carta geolögica do Brasil ao milionēsimo" Folha Goiās (SD-22) e Folha Goiānia(SE -22). DNPM, Brasilia.

SEGALEN, P. - 1968 - "Note sur une mēthode de dētermination de produits minēraux amorphes dans certains sols à hydroxydes tropicaux".- Cah.ORSTOM, sēr.Pēd., 6 (1):105126 .

SEGALEN, P. - 1970 - "Extraction du fer libre de sols à sesquioxydes par la mëthode de De Endredy par irradiation $\bar{a}$ ultraviolet des solutions oxaliques".Cah.ORSTOM, sër.Pëdol., VIIT (4): 483-496.

SMITH, J.W. $\xi$ GREEN, D.H. - 1961 - "The geology of the Musa River Area, Papua"- Keport nọ 52. Bureau of Min. Res.Geol. and Geophysics. Austrālia, 41 p. 
SOUZA, A.M.S.de - 1978 - "Mineralogia e petrologia do comple xo ultramāfico e alcalino de Santa Fë, Goiäs". Tese de Mestrado, Univ.Fed.do Parā, $122 \mathrm{p}$.

SOUZA, J.V.de., SANTOS, P.de S. छ SANTOS, H.de.S. - 1973-"Ca racterização mineralögica de algumas argilas niquelíferas brasileiras". Apresentado no 20 Col. Soc.Br.Micr.ET., Rio de Janeiro.

STACHE, G.A. - 1974 - "Untersuchen zur Geologie,Petrographie, Metamorphose und Genese des basich-ultrabasichen Massivs von Barro Alto, Goiäs (Brasilien). These Techn. Univ. Clausthal, $198 \mathrm{p}$.

TARDY, Y. - 1969 - "Gēochimie des altērations. Etude des arē nes et des eaux te quelques massifs cristallins d'Europe et d'Afrique". Mem.Serv.Cart.Geol.Als e Lorr, 31, 199 p.

TEX; E. den - 1955 - "Secondary a 7 teration of chromite" - Am. Min., 40: $353-355$.

THAYER, T.P. - 1972 - "Some observations and problems concer ning the peridotites and peridotite-gabro complexes of the Goiās belt"- An. XXVI Congr.Br.Geol. Belëm, 1:37.

TRESCASES, J.J. - 1969 - "Gëochimie des altërations et des eaux de surface dans le massif ultrabasique du sud de la Nouvelle-Calédonie".- Büll. Serv.Cart.Geol.Als.Lorr,22 (4): $329-354$.

TRESCASEȘ, J.J. - 1975 - "L'ēvolution gēochimique supergēne des roches ultrabasiques en zone tropicale. Formation de gisements nickëlifëres de Nouvelle-Calēdonie. Mem. ORSTOM, 78,259 p. Paris.

TRESCASES, J.J. $\xi$ OLIVEIRA, S.M.B.de - 1978 - "Alteração dos serpentinitos de Morro do Niquel (MG)". -An.XXX Congr.Br. Geol., 4: 1655-1669. 
TURNER, F.J. $\xi$ VERHOOGEN, J.- 1960 - "Igneous and metamorphic petrology" - McGraw Hill Book Company, Inc.,694 p.

VASCONCELLDS, J.B. et al. - 1973 - "Ocorrēncias minerais das folhas Goiăs e Goiānia".-DNPM 60 distr. Goiânia (inēdi to).

WACKERMANN, J.M. - 1975 - "L'altēration des massifs cristallins basiques en zone tropicale semi-humide. Etude mineralogique et gēochimique des arēnes du Sēnēgal oriental. Consëquences pour la cartographie et la prospection".Th. U.L.P. Strasbourg, $373 \mathrm{p}$.

WHITTAKER, E.J.W. $\xi$ ZUSSMAN, J. - 1956 - "The characterization of serpentine minerals by X-ray diffraction". The Min.Mag., 31(233): 107-126.

WIEWIORA, A. - 1978 - "Ni-containing mixed-layer silicates from Szklary, Lower Silesia, Poland". Bull. BRGM, sect II, 3: 247-261.

WILSON, H.D.B. - 1972 - "Ultramafic rocks and related nickel deposits".- An.XXVI Congr.Br.Geol.Belēm, $1: 38$.

UYEDA; N., HANG,P.T. $\xi$ BRINDLEY,G.W. - 1973- "The nature of gar nierites-II - Electron-optical study". Clay and Clay Min, 21: 41-50.

ZEISSINK, H.E. - 1969 - "The mineralogy and geochemistry of a nickeliferous laterite profile (Greenvale,Queensiand, Australia). Miner.Deposita, 4(2): 132-152.

ZEISSINK, H.E. - 1971 - "Trace elements behavior in two ni ckeliferous laterite profiles". Chem.Geol., $7(1): 25-36$. 


\section{APENDICE I}

DADOS BRUTOS

Constam deste apēndice a descrição dos perfis de alteraçäo estudados, o resultado da anālise granulomētrica das amostras da topossequencia $W 4$ e, finalmente, os dados de anălise quĩmica de 159 amostras, correspondentes a amostras totais e a frações granulomëtricas ou mineralōgicas.

sim representada:

A descrição dos perfis de alteração estä as-

Figura A - Distribuição dos fãcies de altera ção nos diferentes perfis da topossequência XXVII (1-85).

Figura B - Distribuiçăo dos fācies de altera ção nos diferentes perfis da topossequência W4 (121-153).

Figura C - Distribuiçäo dos fäcies de altera ção nos diferentes perfis de poços esparsos:

$$
\begin{aligned}
& \text { Poço G }(104-110) \\
& \text { Poço C }(111-120) \\
& \text { Poço Pe }(86-92) \\
& \text { Poço Py }(93-103)
\end{aligned}
$$

Os dados brutos referentes à anālise granulo mētrica das amostras dos 4 perfis da topossequência w4 encontram-se na figura $D$. São histogramas de frequência relativa, cujas classes são representadas por 4 intervalos de granulação. 

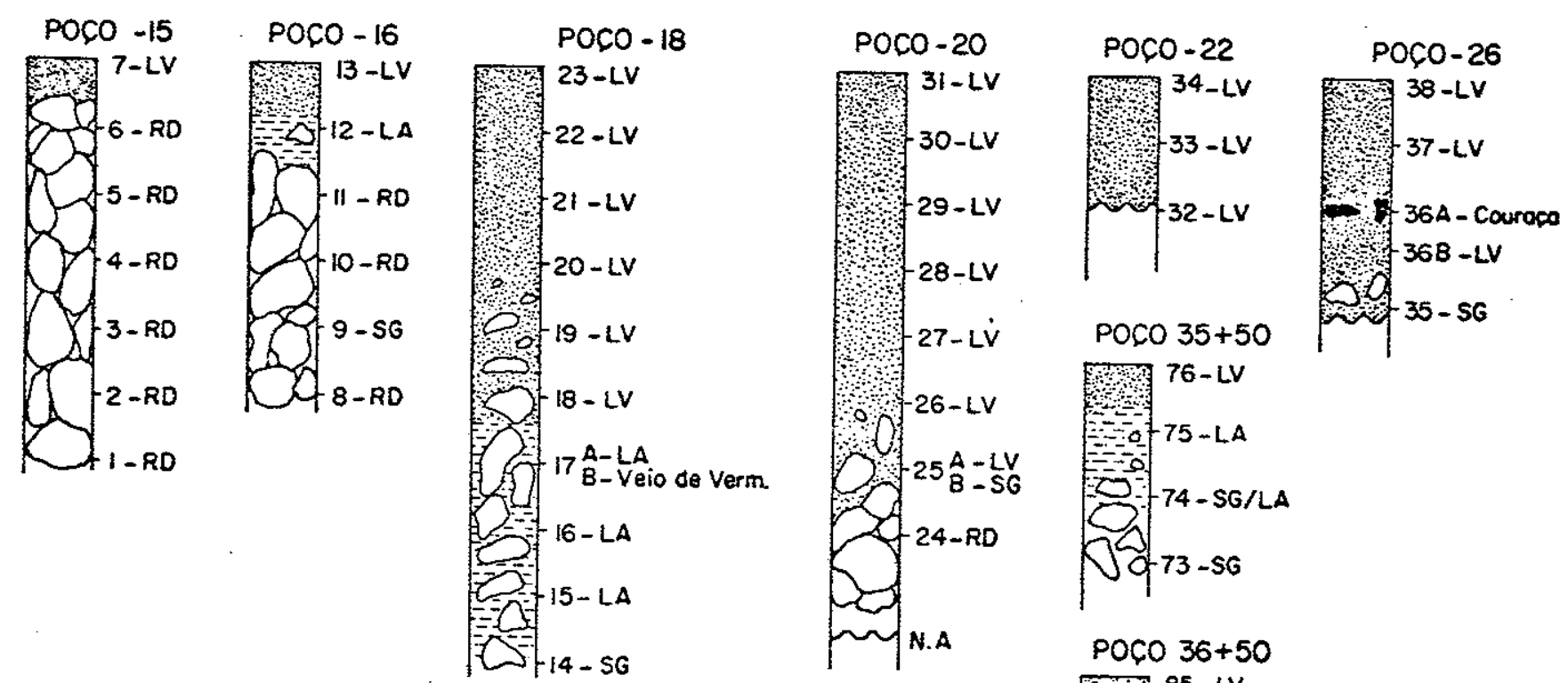

POCO- 28

POCO $35+50$
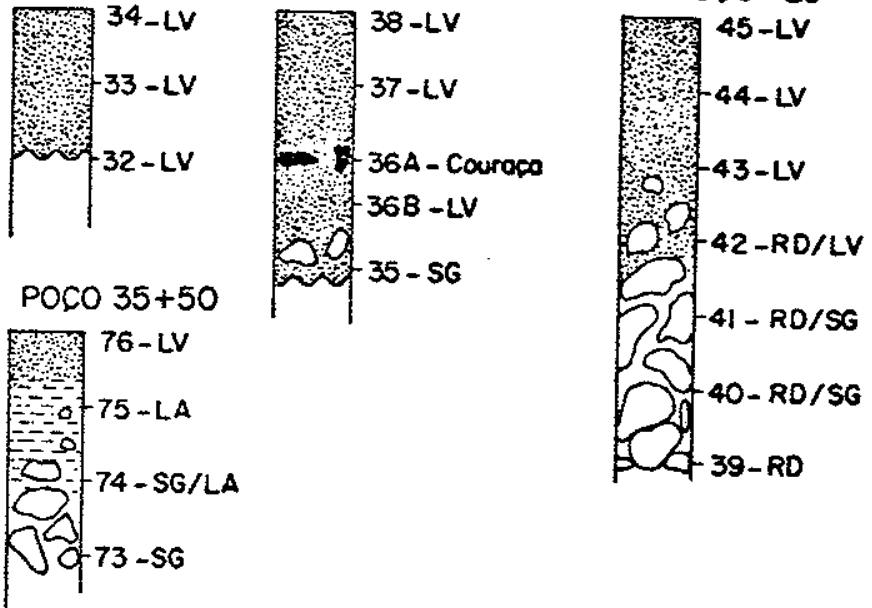

POCO $29+50 \quad$ POCO $30+50$

POCO - 32
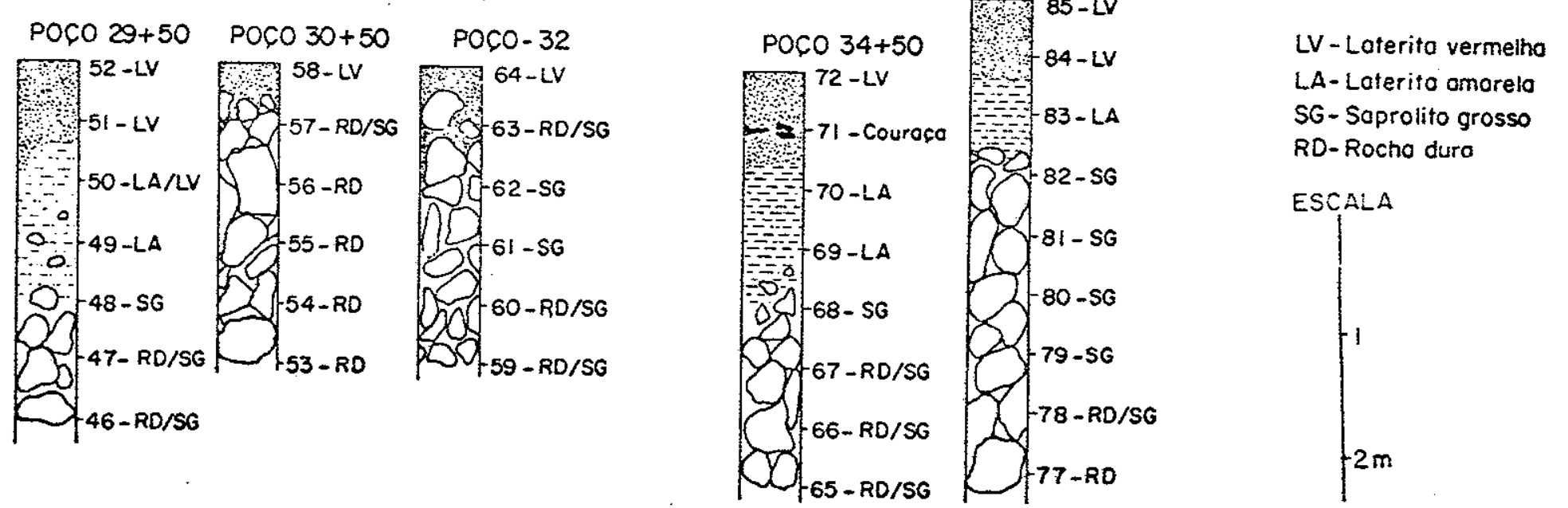

FIGURA A - DISTRIBUIÇÃO DOS FÁCIES DE ALTERAÇAOO NOS

DIFERENTES PERFIS DA TOPOSSEQUENCIA XXVII 

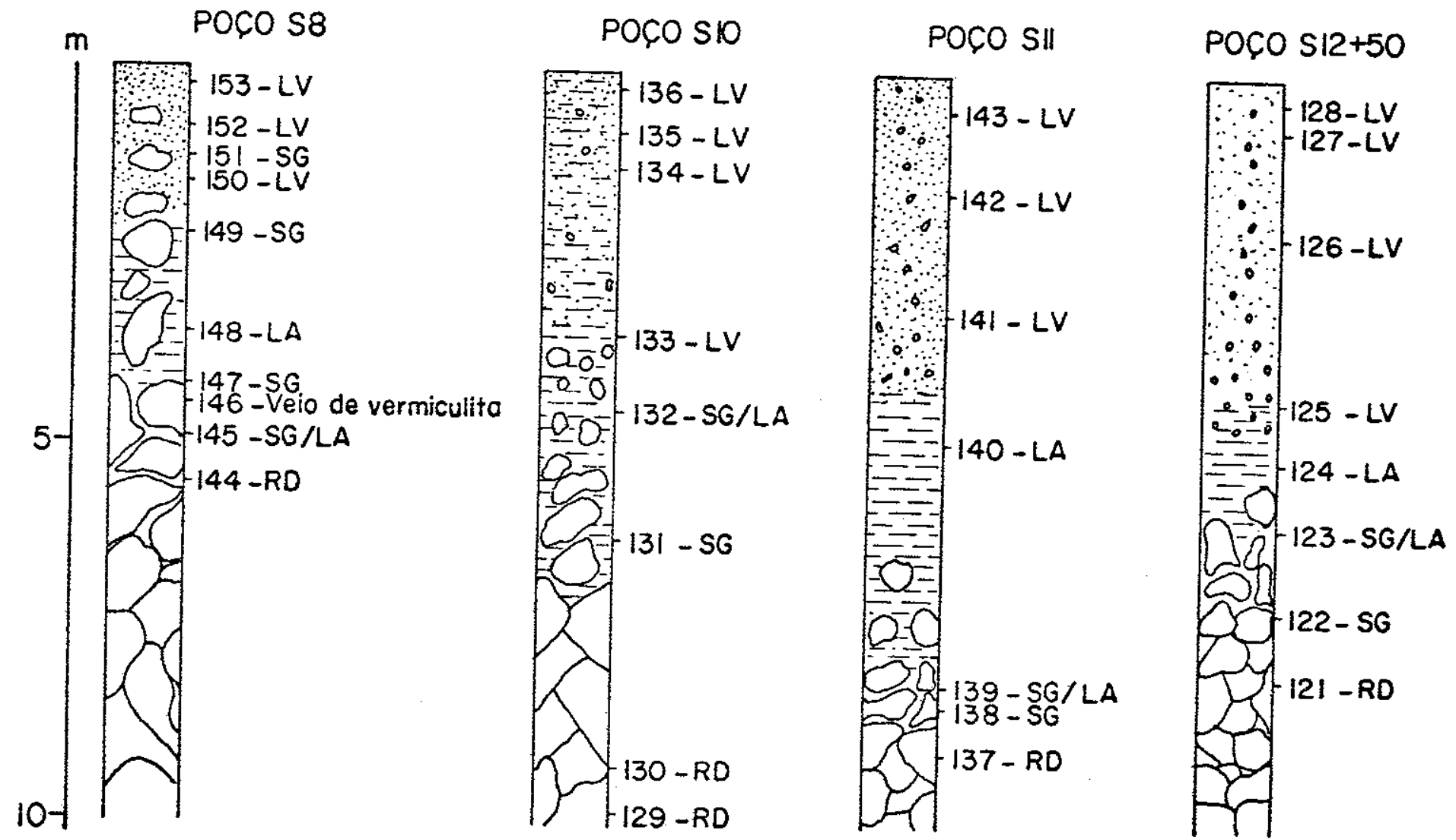

LV-Laterita vermetho LA-Laterito amarelo

SG-Saprolito grosso RD-Rocha dura 

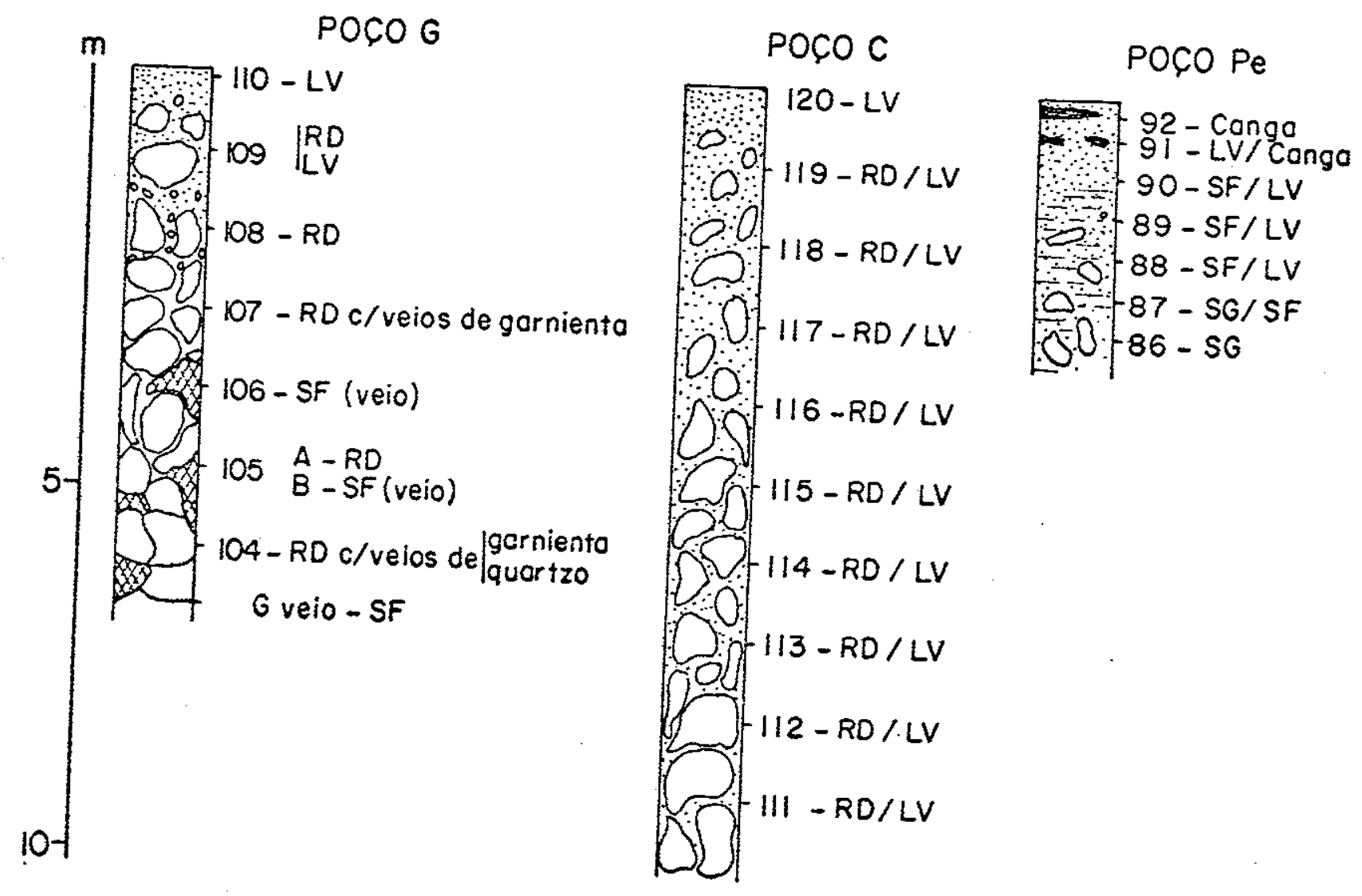

LV-Loterito vermelho SF-Soprolito fino

SG-Saprolito grosso

RD-Rocho duro

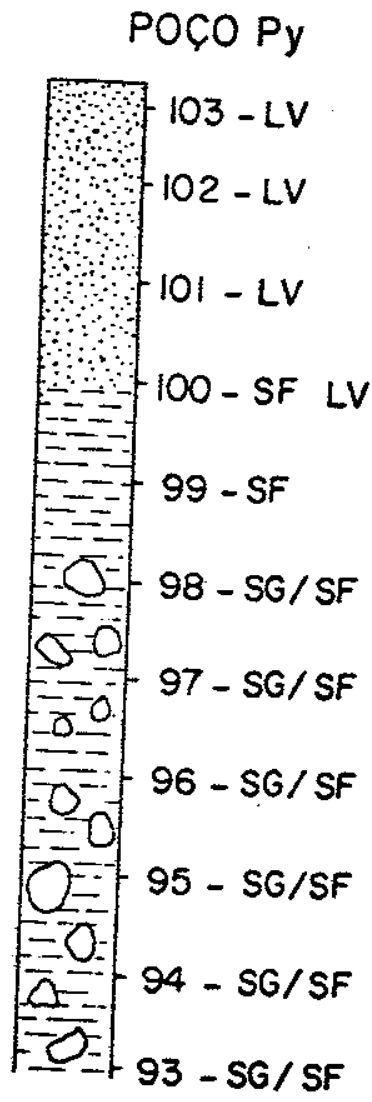

FIGURA C - DISTRIBUIÇÃO DOS FACIES DE ALTERAÇAO NOS DIFERENTES PERFIS DE POÇOS ESPARSOS 


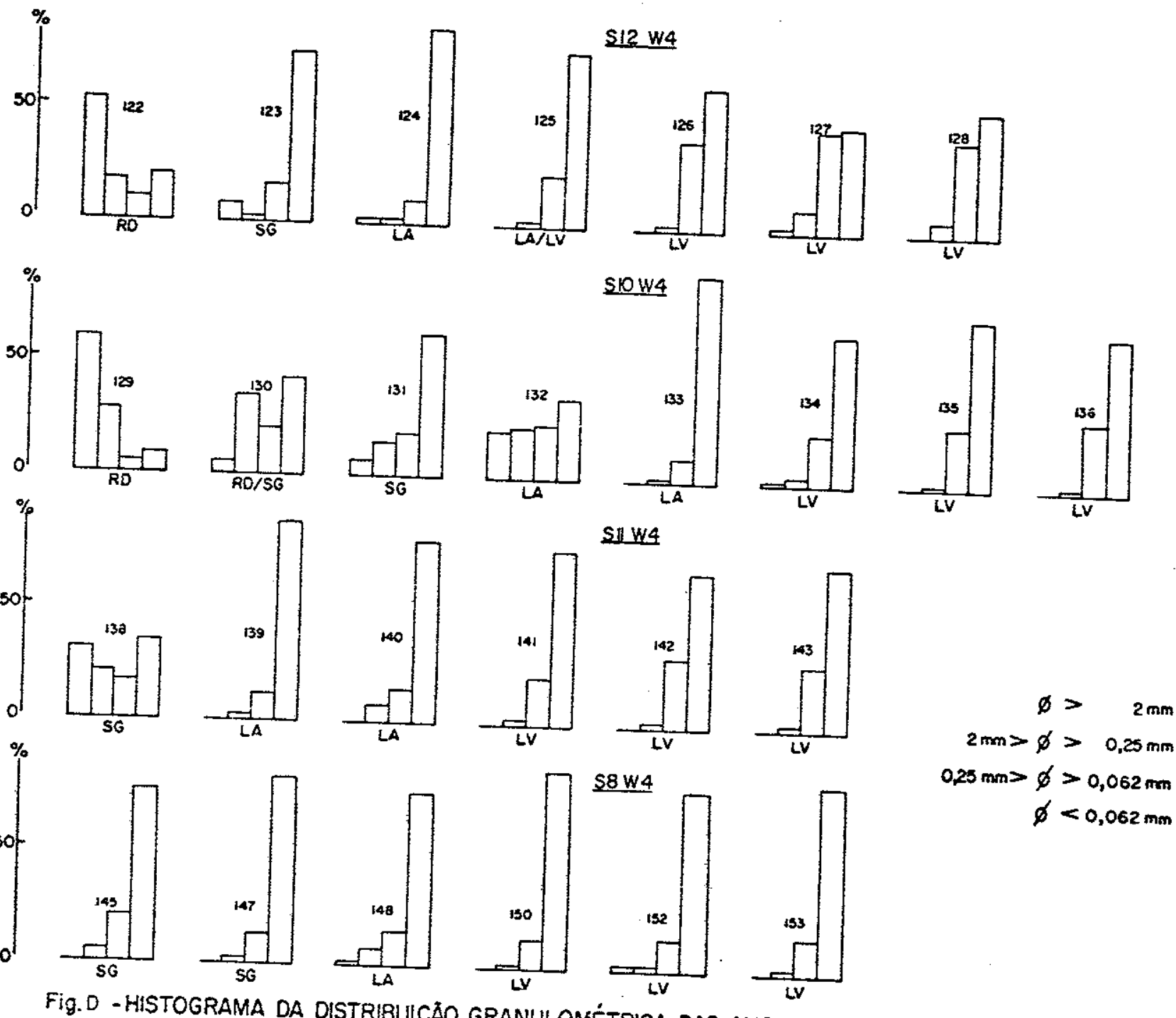


Quanto às anälises quỉmicas, as tabelas que se seguem dizem respeito a:

- anälises de amostras totais dispostas em perfis isolados ou em perfis de topossequencias (1-153)

- analises de minerais ou misturas:

G veio - saprolito verde de um veio do poço $G$

T9-am - vermiculita amarela em grandes placas

T9-ve - vermiculita verde em grandes placas

66-am - serpentina e vermiculita separadas da am 66

33-bo - ö̈Titos separados da am.33

54-br - filme branco recobrindo a am.54: kerolita e serpentina

107-ve - vênula de garnierita cortando a am.107: pimelita, serpentina e quartzo

Ar-a8 - saprolito contido no boxwork silicoso: quartzo, serpentina, vermiculita e pimelita

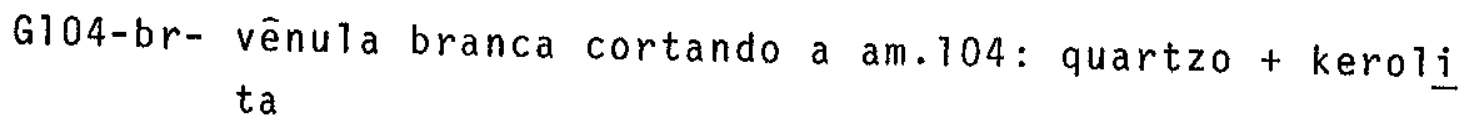

XXVII-17-br - filme branco recobrindo amostra de rocha dura do poço 17 (topossequência XXVII): magnesita, dolomita, kerolita e serpentina

Al-ve - veio de garnierita centimëtrico: quartzo e pimeli ta (amostra cedida pelo Prof. Barbour)

A1-br - vēnula branca cortando rocha dura: dolomita e ser pentina (amostra cedida pelo Prof. Barbour)

- anālises de 3 frações granulomētricas das amostras $114,122,123,124$ e $127:$

$$
\begin{aligned}
A B & =\phi>0,25 \mathrm{~mm} \\
C & =0,25 \mathrm{~mm}>\phi>0,062 \mathrm{~mm} \\
D & =\phi<0,062 \mathrm{~mm}
\end{aligned}
$$


- anālises da sērie BGO:

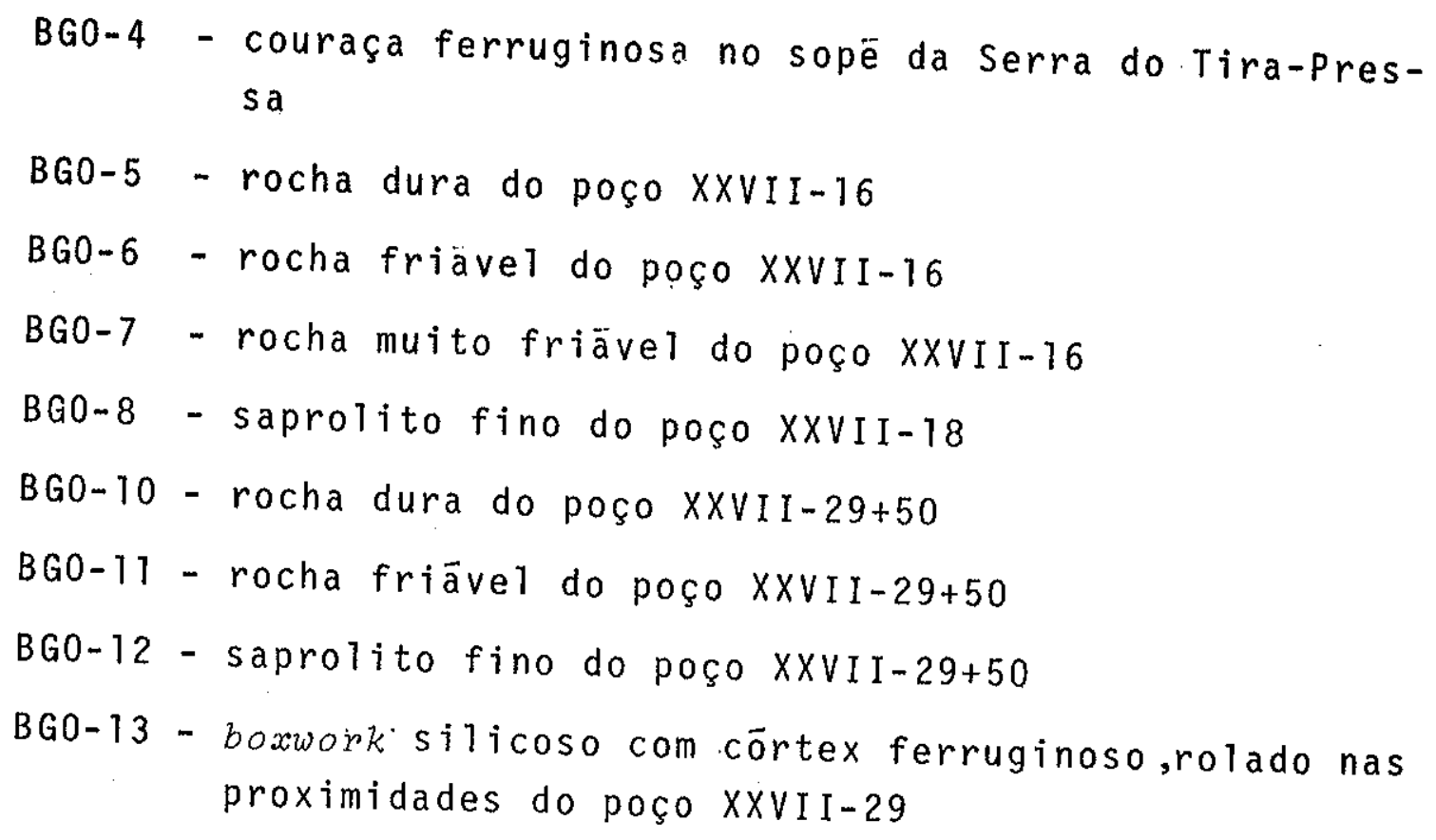


AMOSTRAS TOTAIS

\begin{tabular}{|c|c|c|c|c|c|c|c|c|c|c|c|c|c|c|}
\hline AMOSTRA & $\mathrm{H}_{2} \mathrm{O}^{+}$ & $Q z$ & $\mathrm{SiO}_{2} \mathrm{sol}$ & $\mathrm{SiO}_{2}$ tot. & $\mathrm{MgO}$ & $\mathrm{Fe}_{2} \mathrm{O}_{3}$ & $\mathrm{~A}^{1}{ }_{2} \mathrm{O}_{3}$ & $\mathrm{Cr}_{2} \mathrm{O}_{3}$ & NiO & $\mathrm{CoO}$ & CuO & $\mathrm{MnO}_{2}$ & $\mathrm{CaO}$ & Total \\
\hline 1 & 8,4 & 2,1 & 38,1 & 40,2 & 35,6 & 13,8 & 0,73 & 0,44 & 0,30 & 0,025 & 0,010 & - & - & 99,51 \\
\hline 2 & 10,3 & 2,0 & 37,9 & 39,9 & 34,6 & 13,1 & 0,80 & 0,45 & 0,29 & 0,022 & 0,016 & - & - & 99,48 \\
\hline 3 & 10,7 & 1,8 & 37,3 & 39,1 & 34,5 & 13,2 & 1,00 & 0,53 & 0,29 & 0.025 & 0,018 & - & - & 99,45 \\
\hline 4 & 11,1 & 1,1 & 38,8 & 39,9 & 35,3 & 11,5 & 0,79 & 0,32 & 0,27 & 0,025 & 0,013 & - & - & 99,22 \\
\hline 5 & 10,5 & 0,3 & 37,5 & 37,8 & 35,2 & 12,2 & 0,41 & 0,20 & 0,28 & 0,020 & 0,012 & - & - & 99,52 \\
\hline 6 & 12,0 & 1,7 & 35,6 & 38,3 & 34,1 & 12,3 & 1,50 & 0,42 & 0,35 & 0,029 & 0,031 & - & - & 99,03 \\
\hline 7 & 12,4 & 1,3 & 20,4 & 21,9 & 13,3 & 43,8 & 2,69 & 2,88 & 0,85 & 0,053 & 0,010 & 0,53 & - & 98,32 \\
\hline 3 & 10,4 & 2,1 & 38,5 & 40,6 & 36,1 & 71,0 & 0,80 & 0,39 & 0,27 & 0,020 & 0,013 & - & - & 99,59 \\
\hline 9 & $i 1,4$ & 1,0 & 41,9 & 42,9 & 30,9 & 12,3 & 0,33 & 0,37 & 0,35 & 0,025 & 0,005 & - & - & 93,58 \\
\hline 10 & 6,3 & 1,0 & 36,8 & 37,8 & 42,3 & 31,2 & 0,16 & 0,45 & 0,29 & 0,022 & 0,003 & 0,12 & 0,08 & 98,73 \\
\hline 11 & 12,3 & 1,0 & 35,8 & 37,8 & 38,3 & 11,0 & 0,26 & 0,34 & 0,33 & 0,023 & 0,003 & 0,15 & 0,03 & 100,54 \\
\hline 12 & 10,5 & 1,0 & 37,3 & 38,3 & 30,5 & 17,8 & 0,30 & 0,55 & 0,80 & 0,027 & 0,001 & 0,21 & - & 99,00 \\
\hline 13 & - & - & - & - & - & - & - & - & $\therefore$ & - & - & - & - & - \\
\hline 14 & 11,5 & 1,1 & 43,5 & 44,6 & 27,2 & $i 4,0$ & 0,52 & 0,98 & 0,39 & 0,027 & 0,007 & - & - & 99,22 \\
\hline 15 & 11,1 & 1,2 & 44,4 & 45,6 & 25,5 & 14,9 & 0,39 & 0,67 & 0,87 & 0,032 & 0,004 & - & - & 99,21 \\
\hline 15 & 10.4 & 1.2 & 42.0 & 43,2 & 15,1 & 27,7 & 0.58 & 0,84 & 1,55 & 0,049 & 0.009 & - & - & $.98,83$ \\
\hline 17 & 9,5 & 4,3 & 27,9 & 32,2 & 13,6 & 35,7 & 2,48 & 1,64 & 2,36 & 0,057 & 0,010 & 0,53 & - & 98,08 \\
\hline$i 8$ & 7,8 & 3,3 & 13,5 & 17,4 & $8, ?$ & 56,5 & 1,73 & 3,27 & 2,53 & 0,093 & 0,010 & 0,85 & - & $9 \varepsilon, 88$ \\
\hline 19 & 4,5 & 7,9 & 13,8 & 21,7 & 4,6 & 55,7 & 3,41 & $E, 38$ & 2,22 & 0,097 & 0,008 & 0,93 & - & 99,53 \\
\hline 20 & 2,7 & 5,8 & 3,0 & 8,8 & 2,0 & 72,9 & 2,54 & 8,10 & 1,05 & 0,099 & 0,007 & 1,06 & - & 99,25 \\
\hline 21 & 2,8 & 6,1 & 2,5 & 8,6 & 2,2 & 73,4 & $2,7 i$ & 6,90 & 0,98 & 0,098 & 0,013 & 1,04 & - & 99,00 \\
\hline 22 & 3,8 & 5,9 & 2,7 & 8,6 & 2,0 & 74,7 & 2,91 & 6,55 & 1,16 & 0,108 & 0,018 & - & - & 99,95 \\
\hline 23 & 5,4 & 5,7 & 4,4 & 10,3 & 2,0 & 69,7 & 2,30 & 7,25 & 1,05 & 0,100 & 0,009 & 1,74 & - & 99,05 \\
\hline 24 & 13,6 & 0,8 & 33,6 & 34,4 & 30,6 & 17,4 & 0,41 & 0,23 & 1,85 & 0,035 & 0,003 & - & - & 98,54 \\
\hline $25 A$ & 5,7 & 7,0 & 7,2 & 14,2 & 4,3 & 63,9 & 5,28 & 3,80 & 1,96 & 0,092 & 0,012 & - & - & 99,24 \\
\hline 258 & 9.9 & 15.2 & 30.7 & 45.9 & 22.8 & 18.0 & 0,41 & 0.33 & 3.45 & 0,023 & 0.003 & 0.25 & - & 33,73 \\
\hline 26 & 2,5 & 5,1 & 4,5 & 9,6 & 1,8 & 70,8 & 3,08 & 8,20 & 1,09 & 0,090 & 0,012 & 0,88 & - & 98,05 \\
\hline 27 & - & - & - & - & - & - & - & - & - & - & - & - & - & - \\
\hline
\end{tabular}




\begin{tabular}{|c|c|c|c|c|c|c|c|c|c|c|c|c|c|c|}
\hline AMOSTRA & $\mathrm{H}_{2} \mathrm{O}^{+}$ & $Q z$ & $\mathrm{SiO}_{2} \mathrm{SOl}$ & $\mathrm{SiO}_{2}$ tot. & $\mathrm{MgO}$ & $\mathrm{Fe}_{2} \mathrm{O}_{3}$ & $\mathrm{Al}_{2} \mathrm{O}_{3}$ & $\mathrm{Cr}_{2} \mathrm{O}_{3}$ & NiO & $\mathrm{CoO}$ & cuo & $\mathrm{MnO}_{2}$ & $\mathrm{CaO}$ & Total \\
\hline 28 & 2,1 & 6,6 & 2,3 & 8,9 & 1,5 & 73,3 & 3,42 & 8,28 & 0,83 & 0,091 & 0,011 & 0,86 & - & 99,29 \\
\hline 29 & 2,0 & 6,2 & 2,1 & 8,3 & 3,5 & 73,5 & 3,46 & 8,25 & 0,80 & 0,090 & 0,010 & 0,88 & - & 98,79 \\
\hline 30 & 2,1 & 6,9 & 2,7 & 9,6 & $2,0$. & 72,7 & 3,34 & 7,17 & 0,83 & 0,084 & 0,015 & 0,82 & - & 98,66 \\
\hline 31 & 3,0 & 3,7 & 5,7 & 9,4 & 1,5 & 73,4 & 3,27 & 7,05 & 0,86 & 0,095 & 0,011 & 0,95 & - & 99,55 \\
\hline 32 & 4,4 & 35,2 & 6,6 & 41,8 & 2,2 & 35,2 & 4,09 & 9,45 & 0,79 & 0,040 & 0,010 & 0,21 & 0,01 & 98,20 \\
\hline 33 & $5, ?$ & 35,5 & 7,3 & 42,8 & 2,6 & 35,7 & 3,90 & 7,37 & 0,72 & 0,027 & 0,014 & 0,28 & - & 92,51 \\
\hline $3:$ & 10,1 & 31,1 & 7,2 & 38,3 & 2,2 & 33,9 & 4,18 & 8,83 & 0,75 & 0,028 & 0,016 & $.0,14$ & 0.80 & 99,30 \\
\hline 35 & 13,4 & 1,5 & 35,2 & 36,7 & 30,0 & 14,7 & 0,42 & 0,39 & 2,99 & 0,029 & 0,002 & - & - & 98,63 \\
\hline $35 \mathrm{~A}$ & 5,2 & 4,7 & 2,7 & 7,4 & 1,2 & 71,5 & $5,6 !$ & 4,30 & 1,50 & 0,458 & 0,012 & 2,05 & 0,01 & $10 ?, 34$ \\
\hline 353 & 5.0 & 10,9 & 4,0 & 14,9 & $i, 7$ & 62.8 & 6,62 & 8,21 & 1,30 & 0,253 & 0,010 & 1,11 & 0,02 & 101,92 \\
\hline 37 & 4,4 & 12,8 & 3,9 & 16,7 & 1,8 & 62,9 & 5,70 & 8,58 & 1,17 & $0,1 \div 0$ & 0,010 & 0,63 & 0,01 & 102,04 \\
\hline 38 & - & - & - & - & - & - & - & - & - & - & - & - & - & - \\
\hline 39 & 5,9 & 20,9 & 37,4 & 58,3 & 5,2 & 25,8 & 1,27 & 1,04 & 0,74 & 0,041 & 0,012 & - & - & 98,30 \\
\hline 40 & 4,9 & 42,9 & 30,0 & 72,9 & 7,4 & 12,6 & 0,57 & 0,45 & 0,49 & 0,025 & 0,005 & - & - & 99,35 \\
\hline 41 & 7,2 & 39,3 & 24,6 & 63,9 & 14,2 & 11,1 & 0,83 & 0,54 & 0,70 & 0,018 & 0,028 & - & - & 98,51 \\
\hline 42 & 4,7 & 18,9 & 20,8 & 39,7 & 3,2 & 40,9 & 3,95 & 5,50 & 1,35 & 0,074 & 0,008 & - & - & 99,38 \\
\hline 43 & 4,4 & 19,9 & 7,6 & 27,5 & 2,7 & 49,1 & 4,72 & 8,62 & $.1,27$ & 0,110 & 0,008 & 0,63 & 0,06 & 99,10 \\
\hline 44 & - & - & - & - & - & - & - & - & - & - & - & - & - & - \\
\hline 45 & 7,4 & 15,6 & 9,1 & 24,7 & 3,7 & 47,8 & 4,23 & 9,85 & 1,37 & 0.085 & 0,003 & 0,47 & 0.52 & 99,15 \\
\hline 46 & 13,5 & 2,0 & 39,3 & 41,3 & 30,0 & 12,0 & 0,50 & 1,03 & 0,43 & 0,029 & 0,031 & - & - & 98,92 \\
\hline 47 & 15,2 & $0, i$ & 39,0 & 39,1 & 32,8 & 10,5 & 0,37 & 0,43 & 0,42 & 0,022 & 0,003 & - & - & 98,94 \\
\hline 48 & 14,3 & 0,5 & 39,0 & 39,5 & 31,0 & 12,3 & 0,59 & 0,54 & 0,50 & 0,026 & 0,002 & - & - & 98,56 \\
\hline 49 & 13,1 & 1,2 & 33,7 & 34,9 & 30,3 & 17,2 & 0,43 & $i, 71$ & 0,73 & 0,032 & 0,004 & 0,24 & - & 99,15 \\
\hline 50 & 11,6 & 1,9 & 18,2 & 20,1 & 9,1 & 50,8 & 2,99 & 1,94 & 1,60 & 0,085 & 0,017 & 0,76 & - & 98,99 \\
\hline 51 & 9,3 & 7.7 & 10,9 & 18,6 & 5,8 & 56,9 & 3.17 & 5,08 & 1,60 & 0,104 & 0,012 & 0,47 & 0,05 & 101.02 \\
\hline 52 & - & - & - & - & - & - & - & - & - & - & - & - & - & - \\
\hline$\$ 3$ & 15.4 & 0,2 & 39,9 & 40,1 & 35.9 & 7.5 & 0,11 & 0.14 & 0,32 & 0.015 & 0.003 & - & - & 100,03 \\
\hline
\end{tabular}




\begin{tabular}{|c|c|c|c|c|c|c|c|c|c|c|c|c|c|c|}
\hline AMOSTRA & $\mathrm{H}_{2} \mathrm{O}^{+}$ & $Q z$ & $\mathrm{SiO}_{2} \mathrm{SOI}$. & $\mathrm{SiO}_{2}$ tot. & Mgo & $\mathrm{Fe}_{2} \mathrm{O}_{3}$ & $\mathrm{AI}_{2} \mathrm{O}_{3}$ & $\mathrm{Cr}_{2} \mathrm{O}_{3}$ & $\mathrm{NiO}$ & 000 & CuO & $\mathrm{MnO}_{2}$ & CaO & Total \\
\hline 54 & 14,0 & 0,2 & 38,6 & 38,8 & 35,8 & 7,5 & 0,49 & 0,56 & 0,31 & 0,017 & 0,003 & - & - & 98,48 \\
\hline 55 & 14,9 & 0,4 & 39,9 & 40,3 & 35,6 & 7,3 & 0,33 & 0,31 & 0,33 & 0,017 & 0,002 & - & - & 99,14 \\
\hline 56 & 14,2 & 0,5 & 40,0 & 40,5 & 33,9 & 8,4 & 0,45 & 0,30 & 0,38 & 0,017 & 0,004 & - & - & 98,15 \\
\hline 57 & 14,5 & 0,3 & 40,3 & 40,8 & 35,7 & 7,3 & 0,35 & 0,20 & 0,33 & 0,018 & 0,003 & - & - & 99,00 \\
\hline 58 & - & - &.- & - & - & - & - & - & - & - & - & - & - & - \\
\hline $5 \& L A$ & 14,4 & 0,8 & 35,7 & 36,5 & 33,8 & 14,9 & 0.26 & 0,34 & 0.84 & 0,029 & 0,004 & 0,21 & 0,01 & 101,29 \\
\hline 59 & 9,7 & 21,1 & 37,2 & 58,3 & 22,2 & 6,3 & 1,31 & 0,15 & 0,17 & 0,012 & 0,010 & - & - & 98,15 \\
\hline 60 & 13,1 & 0,2 & 45,2 & 45,4 & 30.5 & 9,7 & 0,46 & 0,29 & 0,31 & 0,018 & 0,004 & - & - & 99,78 \\
\hline $6 i$ & 13,2 & 3,7 & 37,8 & 41,5 & 30,2 & 12,3 & 0,51 & 0,52 & 0,32 & 0,021 & 0,003 & - & - & 98,57 \\
\hline 52 & 13,7 & 1,4 & 43,2 & 44,6 & 30,6 & 7,9 & 0,62 & 0,35 & 0,32 & 0,016 & 0,003 & - & - & 98,11 \\
\hline 63 & 14,1 & 5,9 & 37,8 & 43,7 & 31,1 & 7,5 & 0,37 & 0,88 & 0,33 & 0,015 & 0,002 & - & - & 98,00 \\
\hline 64 & 12,7 & - & - & 22,6 & 6,2 & 44,5 & 3,53 & 5,69 & 1,69 & 0,078 & 0,008 & 0,38 & - & 97,60 \\
\hline 55 & 14,3 & 0,7 & 40,9 & 41,6 & 32,7 & 8,8 & 0,55 & 0,76 & 0,28 & 0,024 & 0,002 & - & - & 98,43 \\
\hline 55 & 14,2 & 0,2 & 42,2 & 42,4 & 32,9 & 8,4 & 0,31 & 0,33 & 0,33 & 0,073 & 0,002 & - & - & 98,89 \\
\hline 67 & 14,2 & 0,5 & 40,2 & 40,7 & 34,1 & 9,0 & $0,4 i$ & 3,45 & 0,41 & 0,029 & 0,002 & - & - & 99,30 \\
\hline 68 & 14,4 & 0,3 & 41,6 & 41,9 & 32,7 & 8,0 & 0,28 & 0,37 & 0,39 & 0,019 & 0,003 & - & - & 98,06 \\
\hline 69 & 12,9 & 3,3 & 37,6 & 40,9 & 28,5 & 13,4 & 7,60 & 1,43 & 0,37 & 0,025 & 0,004 & 0,20 & - & $99,<3$ \\
\hline 70 & 12,1 & 2,2 & 36,5 & 38,7 & 25,9 & 18,7 & 1,76 & 0,92 & 0,54 & 0,027 & 0,003 & 0,26 & - & 98,91 \\
\hline 71 & - & - & - & - & - & $\sim$ & - & - & - & - & - & - & - & - \\
\hline 72 & 12,1 & 8,6 & 16,5 & 25,2 & 7,1 & 45,8 & 4,42 & 3,57 & 1,30 & 0,074 & 0,003 & 0,32 & 0,05 & 100,06 \\
\hline 73 & 13,1 & 0,5 & 42,3 & 43,4 & 31,4 & 10,7 & 0,42 & 0,33 & 0,27 & 0,025 & 0,007 & - & - & 99,05 \\
\hline 74 & 12.9 & 0,7 & 42,7 & 42,8 & 30,3 & 11,1 & 0,49 & 0,59 & 0,34 & 0,024 & 0,008 & - & - & 98,35 \\
\hline 75 & 14,1 & 0,7 & 39,0 & 39,7 & 33,0 & 10,9 & 0,34 & 0,35 & 0,42 & 0,018 & 0,003 & - & - & 98,83 \\
\hline 76 & 13,4 & 8,2 & 25,6 & 34,3 & 20,7 & 24,0 & 1,69 & 4,60 & 0,74 & 0,036 & 0,004 & 0,21 & 0,70 & 100,88 \\
\hline 77 & 13,2 & 0,7 & 42,2 & 42,9 & 30,1 & 10,5 & 0,56 & 0,72 & 0,38 & 0,019 & 0,002 & 0,13 & - & 98,51 \\
\hline 78 & 15,1 & 0,7 & 38,1 & 38,8 & 29,0 & 11,9 & 3,92 & 0,23 & 0,32 & 0,016 & 0,004 & 0,75 & - & 99,44 \\
\hline 79 & 14.0 & 0.9 & 39.0 & 39,9 & 30,3 & 13.1 & 0.41 & 1.34 & 0.33 & 0,038 & 0.005 & - & - & 33,27 \\
\hline
\end{tabular}




\begin{tabular}{|c|c|c|c|c|c|c|c|c|c|c|c|c|c|c|}
\hline AMDSTRA & $\mathrm{H}_{2} \mathrm{O}^{+}$ & $Q z$ & $\mathrm{SiO}_{2} \mathrm{SOl}^{\circ}$ & $\mathrm{SiO}_{2}$ tot. & $\mathrm{MgO}$ & $\mathrm{Fe}_{2} \mathrm{O}_{3}$ & $\mathrm{Al}_{2} \mathrm{O}_{3}$ & $\mathrm{Cr}_{2} \mathrm{O}_{3}$ & NiO & 100 & CuO & $\mathrm{MnO}_{2}$ & $\mathrm{CaO}$ & Total \\
\hline $\begin{array}{l}80 \\
81\end{array}$ & $\begin{array}{l}14,1 \\
14,5\end{array}$ & $\begin{array}{l}0,8 \\
0,8\end{array}$ & 40,0 & 40,8 & 32,3 & 10,8 & 0,59 & 0,91 & 0,45 & 0,019 & 0,002 & - & - & 99,97 \\
\hline $\begin{array}{l}81 \\
82\end{array}$ & $\begin{array}{l}14,5 \\
14,0\end{array}$ & 0,8 & 38,7 & 39,5 & 37,9 & 10,2 & 1,35 & 0,40 & 0,35 & 0,018 & 0,005 & - & - & 98,22 \\
\hline $\begin{array}{l}82 \\
83\end{array}$ & $\begin{array}{l}14,0 \\
13,2\end{array}$ & 0,5 & 44,2 & 44,8 & 30,6 & 9,5 & 0,51 & 0,13 & 0,42 & 0,053 & 0,005 & - & - & 100,02 \\
\hline $\begin{array}{l}83 \\
84\end{array}$ & $\begin{array}{r}13,2 \\
8,4\end{array}$ & 1,5 & 37,0 & 38,5 & 25,2 & 19,1 & 1,00 & 1,50 & $0,8 i$ & 0.037 & 0,005 & - & - & 99,35 \\
\hline & $\begin{array}{l}8,4 \\
-\end{array}$ & 4,5 & 12,6 & 17,1 & 8,0 & 49,4 & 4,06 & 8,75 & 1,24 & 0,067 & 0,008 & 0,36 & 0,57 & 95,97 \\
\hline 83 & - & $\cdots$ & - & - & - & - & - & - & - & - & - & - & - & - \\
\hline 86 & 3,6 & - & - & 36,7 & 10,0 & 28,6 & 3,78 & 0,02 & 0,32 & 0,022 & 0,058 & 0.21 & 15,12 & 97.83 \\
\hline 87 & 5,0 & - & - & 31,8 & 9,0 & 35,8 & 4,42 & 0,03 & 0,45 & 0,025 & 0,043 & 0,24 & 10,92 & 97,73 \\
\hline 83 & 8,0 & - & - & 27,2 & 7,0 & 40,0 & 4,72 & 0,07 & 0,54 & 0,025 & 0,225 & 0,25 & 5,74 & 93,77 \\
\hline$s 9$ & 9,0 & - & - & 21,6 & 4,6 & 53,0 & 6,80 & 0,04 & 0,89 & 0,027 & 0,188 & 0,25 & 2,28 & 98,58 \\
\hline 90 & - & - & - & - & - & - & - & - & - & - & - & - & - & - \\
\hline 91 & - & - & - & - & - & - & - & * & - & - & - & $\rightarrow$ & + & - \\
\hline 92 & & - & & - & - & - & - & - & - & - & - & $\therefore$ & - & - \\
\hline 93 & 14,7 & - & - & 45,8 & 11,8 & 17,9 & 6,80 & $0, i 2$ & 0,14 & 0,015 & 0,011 & 0,17 & 2,80 & 100,25 \\
\hline 94 & - & - & - & - & - & - & - & - & - & - & - & - & $=$ & - \\
\hline 95 & 9,5 & - & - & 47,7 & 13,8 & 14,7 & 4,34 & 0,09 & 0,05 & 0,008 & 0,070 & 0,08 & 7,28 & 97,63 \\
\hline 96 & - & - & - & - & - & - & - & - & - & - & - & - & - & - \\
\hline 97 & 4,9 & - & - & 45,5 & 14,8 & 18,3 & 4,25 & 0,23 & 0,09 & 0,019 & 0,008 & 0,17 & 13,85 & 102,13 \\
\hline 98 & 10,7 & - & - & 46,9 & 12,9 & 17,2 & 5,29 & 0,20 & 0,10 & 0,017 & 0,005 & 0,16 & 8,12 & 101,59 \\
\hline 99 & $i i, 4$ & - & - & 42,3 & 10,1 & 24,7 & 5,43 & 0,29 & 0,18 & 0,019 & 0,009 & 0,20 & 3,78 & 99,47 \\
\hline 100 & 4,7 & - & - & 59,5 & 0,60 & 29,3 & 5,34 & 0,65 & 0,32 & 0,030 & 0,010 & 0,14 & - & 100,52 \\
\hline 101 & - & - & - & - & - & - & - & - & - & - & - & - & - & - \\
\hline 102 & 6.3 & - & - & 35,9 & 0,99 & 40,1 & 10,9 & 1,45 & 0,38 & 0,035 & 0,019 & 0,22 & 0,15 & 96,45 \\
\hline 103 & - & - & - & - & - & - & - & - & - & - & - & - & - & - \\
\hline 104 & 12,9 & 1,3 & 39,9 & 41,2 & 34,4 & 8,7 & 0,36 & 0,35 & 0,36 & 0,014 & 0,003 & 0,11 & 0,85 & 99,24 \\
\hline $105 \mathrm{~A}$ & 13,7 & 1,6 & 34,9 & 36,5 & 32,3 & 15,7 & 0,11 & 0,36 & 0,93 & 0,039 & 0,002 & 0,19 & 0,13 & 99,34 \\
\hline $105 B$ & 13,3 & 2,0 & 34,1 & 36,1 & 26,9 & 13,9 & 4,33 & 0,10 & 3,50 & 0.017 & 0,011 & 0,24 & 2,45 & 100,84 \\
\hline 106 & 13,9 & 3.1 & 30,6 & 33,7 & 25.7 & 15,7 & 6,04 & 0,10 & 3.27 & 0.017 & 0,003 & 0.18 & 1.54 & 100.14 \\
\hline
\end{tabular}




\begin{tabular}{|c|c|c|c|c|c|c|c|c|c|c|c|c|c|c|}
\hline AMOSTRA & $\mathrm{H}_{2} \mathrm{O}^{+}$ & $Q z$ & $\mathrm{SiO}_{2} \mathrm{SOI}$ & $\mathrm{SiO}_{2}$ tot. & $\mathrm{MgO}$ & $\mathrm{Fe}_{2} \mathrm{O}_{3}$ & $\mathrm{~A}_{2} \mathrm{O}_{3}$ & $\mathrm{Cr}_{2} \mathrm{O}_{3}$ & Nio & $\mathrm{COO}$ & CuO & $\mathrm{MnO}_{2}$ & $\mathrm{CaO}$ & Totar \\
\hline 107 & 10,8 & 3,6 & 33,0 & 36,5 & 28,2 & 18,5 & 0,36 & 0,54 & 3,84 & 0,090 & 0,003 & 0,28 & 1,30 & 100,51 \\
\hline 108 & 10,8 & 5,9 & 33,5 & 39,4 & 30,7 & 14,7 & 0,19 & 0,70 & 2,10 & 0,025 & 0,002 & 0.18 & 0,74 & 99.53 \\
\hline 109 & 13,0 & 0.8 & 34.8 & 35,5 & 32,3 & 16,5 & 0,19 & 0,58 & 1,96 & 0,034 & 0,002 & 0,20 & 0,03 & 100,39 \\
\hline $109 L Y$ & 9,5 & 11,5 & 15,8 & 27,3 & 12,5 & 43,8 & 1,00 & 2,80 & 2,86 & 0,038 & 0,002 & 0,57 & 0,18 & 100,55 \\
\hline $1: 0$ & 11.4 & 20,8 & 9,3 & 30.1 & 4.0 & 45,9 & 1,63 & 3,10 & 2,43 & 0,064 & 0,002 & 0,63 & 0,03 & 100,29 \\
\hline 111 & 5,1 & 21,5 & 34,9 & 56,4 & 0,7 & 34,7 & 1,51 & 1.23 & 0,73 & 0,021 & 0,009 & 0,38 & 0,04 & 100,98 \\
\hline 112 & - & - & - & - & - & - & - & - & - & - & - & - & - & - \\
\hline 113 & $\begin{array}{l}- \\
-\end{array}$ & - & - & - & -. & - & - & - & - & - & - & - & - & - \\
\hline 114 & - & - & - & - & - & - & - & $*$ & - & - & - & - & - & - \\
\hline 115 & - & - & $=$ & - & - & - & - & - & - & - & - & - & - & - \\
\hline 116 & - & - & - & - & - & - & - & - & - & - & - & - & - & - \\
\hline 117 & - & - & - & - & - & - & - & - & - & - & - & - & - & - \\
\hline 118 & 2,4 & 29.2 & 49,4 & 78,6 & 0,3 & 15,3 & 0,47 & 0,66 & 0,29 & 0,025 & 0,004 & 0,15 & 0,03 & 98,23 \\
\hline 113 & - & - & $\cdot$ & - & - & - & - & - & - & - & - & - & - & - \\
\hline 120 & - & - & - & - & - & - & - & - & - & - & - & - & - & - \\
\hline 121 & 12,3 & 0,2 & 37,5 & 37,7 & 37,3 & 13,2 & 0,17 & 0,25 & 0,27 & 0,017 & 0,011 & 0,15 & 0,35 & 101,72 \\
\hline 122 & 12,8 & 1,2 & 39,3 & 40,5 & 37,2 & 14,1 & 0,65 & 0,33 & 0,59 & 0,022 & 0,003 & 0,19 & 0,16 & 300,51 \\
\hline 123 & 11,8 & 5,4 & 25,3 & $3 i, 7$ & 19,9 & 32,9 & 0,27 & 0,60 & 2,65 & 0,050 & 0,003 & 0,44 & 0,32 & 100,34 \\
\hline 124 & 8,9 & 28,2 & $2 i, 5$ & 49,7 & 13,0 & 25,8 & 0,39 & 0,91 & 2,29 & 0,038 & 0,003 & 0,31 & 0,03 & 101,35 \\
\hline 125 & $i, 3$ & 3,2 & 4,3 & 7,5 & 1,4 & 73,7 & 2,25 & 4,87 & 1,93 & 0,104 & 0,010 & 0,63 & $0,0 i$ & 99,70 \\
\hline 126 & - & - & - & - & - & - & - & - & - & - & - & - & - & - \\
\hline 127 & 4,6 & 8,3 & 2,5 & 10,8 & 1,0 & 74,5 & 3,44 & 4,87 & 0,79 & 0,055 & 0,005 & 0,44 & 0,00 & 100,50 \\
\hline 328 & - & - & - & - & - & - & - & - & - & - & - & - & - & - \\
\hline 129 & 7,2 & $34, ?$ & 22,8 & 56,9 & 22,4 & 7,1 & 1,22 & 0,22 & 0,13 & 0,010 & 0,006 & 0.03 & 3,33 & 98,60 \\
\hline 130 & - & - & - & - & - & - & - & - & - & - & - & - & - & - \\
\hline 131 & 11.6 & 10,0 & 24,3 & 34,3 & 17,2 & 32,3 & 0,55 & 0,60 & 0,80 & 0,050 & 0,004 & 0,38 & 1.07 & 98,85 \\
\hline 132 & 12,1 & 4,4 & 34,4 & 38,8 & 25,7 & 18,1 & 0,42 & 0,32 & 1,60 & 0,027 & 0,005 & 0,23 & 1,57 & 38,87 \\
\hline 133 & - & - & - & - & - & - & - & - & - & $\cdot$ & - & - & & \\
\hline
\end{tabular}




\begin{tabular}{|c|c|c|c|c|c|c|c|c|c|c|c|c|c|c|}
\hline ANOSTRA & $\mathrm{H}_{2} \mathrm{O}^{+}$ & $Q z$ & $\mathrm{SiO}_{2} \mathrm{SOI}$ & $\mathrm{SiO}_{2}$ tot. & $\mathrm{MgO}$ & $\mathrm{Fe}_{2} \mathrm{O}_{3}$ & $\mathrm{~A}] 2{ }_{2}, 3$ & $\mathrm{Cr}_{2} \mathrm{O}_{3}$ & NiO & CoO & CuO & $\mathrm{NnO}_{2}$ & $\mathrm{CaO}$ & Total \\
\hline $\begin{array}{l}134 \\
135\end{array}$ & 4,0 & 7,3 & 3,0 & 10,3 & - & - & - & - & - & - & - & - & - & - \\
\hline 136 & - & $\begin{array}{l}7,3 \\
-\end{array}$ & $\begin{array}{c}3,0 \\
-\end{array}$ & 10,3 & 1,1 & 73,1 & 3,04 & 5,14 & 0,90 & 0,090 & 0,008 & 0,73 & 0,02 & 98,41 \\
\hline & & & - & - & - & - & - & - & - & - & - & - & - & - \\
\hline 137 & 14,1 & 1,0 & 36,6 & 37,6 & 32,8 & 12,9 & $0,1.3$ & 0,17 & 0,28 & & & & & \\
\hline 138 & 13,0 & 1,2 & 36,1 & 37,3 & 29,8 & 16,5 & 0,73 & 0,34 & $\begin{array}{l}0,28 \\
1,44\end{array}$ & 0,022 & 0,007 & 0,18 & 0,01 & 98,19 \\
\hline 139 & 13,4 & 4,1 & $19,9$. & 24,0 & 19,7 & 37,0 & 0,34 & 1,28 & & 0,032 & 0,004 & 0,27 & 0,11 & 98,98 \\
\hline 140 & 9,3 & 3,5 & 5,5 & 9,1 & 2,8 & 66,5 & 1,90 & 4,36 & 2,29 & 0,056 & 0,005 & 0,37 & 0,02 & 98,45 \\
\hline 141 & - & - & - & - & - & - & - & - & 2,62 & 0,152 & 0,006 & 1,09 & 0,42 & 98,34 \\
\hline 142 & 12,1 & 7,8 & 2,8 & 10,6 & 0,9 & 70,3 & 3,56 & & - & - & - & - & - & - \\
\hline $1 \leqslant 3$ & - & - & - & - & - & - & - & $\begin{array}{l}3,24 \\
-\end{array}$ & 0,83 & 0,090 & 0,010 & 0,60 & 0,02 & 102,30 \\
\hline & & & & & & & & & & & & & & \\
\hline 145 & 12,3 & 0,1 & & & & 12,5 & 0,06 & 0,26 & 0,22 & $0,02\}$ & 0,005 & 0,16 & 0,12 & 99,93 \\
\hline 145 & - & - & & $\begin{array}{c}38,9 \\
-\end{array}$ & 19,9 & 27,1 & 0,21 & 0,23 & 0,58 & 0,049 & 0,011 & 0,37 & 0,14 & 99,78 \\
\hline 147 & 13,7 & 0,8 & 20,3 & 21,1 & - & - & - & - & - & - & - & - & - & - \\
\hline 148 & 5,3 & 35,2 & 29,2 & $\begin{array}{l}21,1 \\
64,4\end{array}$ & $8, ?$ & $54, ?$ & 0,60 & 0,33 & $i, 25$ & 0,095 & 0,020 & 0,63 & 0,03 & 97,36 \\
\hline 149 & 13,1 & 0,0 & 36,7 & $\begin{array}{l}64,4 \\
36,7\end{array}$ & 11,2 & 13,2 & 1,40 & 1,75 & 0,44 & 0,021 & 0,008 & 0,16 & 0,75 & 98,61 \\
\hline 150 & - & - & - & 36,7 & 32,1 & 16,5 & 0,25 & $0,44$. & 1,57 & 0,029 & 0,005 & 0,22 & 0,13 & 101,01 \\
\hline 151 & - & - & - & - & - & - & - & - & - & - & - & - & - & - \\
\hline 152 & 5,6 & 0,1 & 33,3 & 13,4 & $\therefore$ & - & - & - & - & - & - & - & - & - \\
\hline 153 & - & - & - & $\begin{array}{l}13,4 \\
-\end{array}$ & $\begin{array}{l}1,2 \\
-\end{array}$ & $\begin{array}{c}73,3 \\
-\end{array}$ & $\begin{array}{c}2,68 \\
-\end{array}$ & 2,20 & 1,50 & $0,1 T 2$ & 0,016 & 0,63 & 0,01 & 100,53 \\
\hline
\end{tabular}


FRAÇOES GRANULOMETRICAS

\begin{tabular}{|c|c|c|c|c|c|c|c|c|c|c|c|c|c|c|c|}
\hline AMOS & STRA & $\mathrm{H}_{2} \mathrm{O}^{+}$ & $Q z$ & $\mathrm{SiO}_{2} \mathrm{SOI}$ & $\mathrm{SiO}_{2}$ tat. & $\mathrm{MgO}$ & $\mathrm{Fe}_{2} \mathrm{O}_{3}$ & $\mathrm{~A}^{\mathrm{A}} \mathrm{O}^{\mathrm{O}} 3$ & $\mathrm{Cr}_{2} \mathrm{O}_{3}$ & NiO & CoO & CuO & $\mathrm{MnO}_{2}$ & $\mathrm{CaO}$ & Tota? \\
\hline 114 & $A B$ & 3,0 & 37,3 & 36,6 & 73,9 & 0,5 & 20,2 & 0,72 & 0,93 & 0,37 & 0,100 & 0,007 & 0.37 & 0.08 & 100,18 \\
\hline 114 & $c$ & 6,1 & 36,3 & 7,1 & 43,4 & 1,0 & 41,7 & 3,60 & 2,38 & 0,78 & 0,050 & 0,046 & 0,26 & - & 99,32 \\
\hline 114 & 0 & 5.8 & 22,9 & 5,5 & 28,4 & 1,2 & 51,7 & 3.55 & 3.66 & $0,81^{\circ}$ & 0,057 & 0,021 & 0,32 & - & 96,53 \\
\hline 122 & $A B$ & 12,0 & 1.2 & 36,8 & 38,0 & 34,5 & 15,5 & 0.17 & 0,58 & 0,46 & 0,024 & 0,003 & 0,21 & 0,10 & 102,55 \\
\hline 122 & $c$ & 11,8 & $\mathrm{~T}, 4$ & 39,0 & 40,4 & 31,6 & 15,0 & 1,20 & 1,62 & 0,50 & 0,029 & 0,003 & 0,22 & 0,35 & 102,82 \\
\hline 122 & $D$ & 13,1 & 1,5 & 38,3 & 39,8 & 30,7 & 15,8 & 0,83 & 0,52 & 0,69 & 0,058 & 0,025 & 0,42 & 0,45 & 102,39 \\
\hline 123 & $A B$ & 12,3 & 3,0 & 34,0 & 37,0 & 24.6 & 22,9 & 0,25 & 0,31 & 1,78 & 0,038 & 0.004 & 0,29 & 0,07 & 100,14 \\
\hline 123 & $c$ & 8,2 & 3,3 & 23,2 & 26,5 & 20,0 & 34,8 & 1,05 & 9,48 & 1,44 & 0,043 & 0,011 & 0,34 & 0,07 & 101,93 \\
\hline 123 & $D$ & 13,8 & $0,9$. & 22,9 & 23,8 & 17,8 & 43,0 & 0,29 & 0,45 & 2,51 & 0,081 & 0,053 & 0,60 & 0,55 & 101,85 \\
\hline 124 & $A 3$ & 10,5 & 14,8 & 26,6 & 41,4 & 20,8 & 23,3 & 0,39 & 1,32 & 2,39 & 0,029 & 0,006 & 0,27 & 0,13 & 100,54 \\
\hline 124 & $c$ & 1,5 & - & - & 15,4 & 5,0 & 51,9 & 1,98 & 23,54 & $\mathrm{I}, 25$ & 0,076 & 0,004 & 0.59 & 0,04 & 102.35 \\
\hline 124 & 0 & 11,1 & 5,3 & 12,5 & 17,8 & 6,6 & 56,5 & 0,79 & 0,92 & 3,37 & 0,076 & 0.086 & 0,52 & - & 27,75 \\
\hline 127 & $A B$ & 4,3 & 7,3 & 4,3 & $1 i, 6$ & 1,0 & 63,0 & 5,78 & 7,02 & 0,80 & 0,239 & 0.012 & 1,19 & 4,45 & 99,39 \\
\hline 127 & $c$ & 2,1 & 8,4 & 0,4 & 8,8 & 1,6 & 75,3 & 3,56 & 5,09 & 0,79 & 0,120 & 0,008 & 0,63 & - & 99,00 \\
\hline 127 & D & 3,1 & 8,7 & 2,3 & 11,0 & 1,7 & 74,5 & 3,29 & 6,31 & 0,72 & 0,058 & 0,036 & 0,35 & - & 101,07 \\
\hline
\end{tabular}


MINERAIS OU MISTURAS

\begin{tabular}{|c|c|c|c|c|c|c|c|c|c|c|c|c|c|c|}
\hline AMOSTRA & $\mathrm{H}_{2} \mathrm{O}^{+}$ & $Q z$ & $\mathrm{SiO}_{2} \mathrm{SOl}$ & $\mathrm{SiO}_{2}$ tot. & $\mathrm{MgO}$ & $\mathrm{Fe}_{2} \mathrm{O}_{3}$ & $\mathrm{~A}_{2} \mathrm{O}_{3}$ & $\mathrm{Cr}_{2} \mathrm{O}_{3}$ & No & .000 & cuo & $\mathrm{MnO}_{2}$ & $\mathrm{CaO}$ & Total \\
\hline G-veio & 13,2 & 1,6 & 33,6 & 35,2 & 25,7 & 14,0 & 4,53 & 0,05 & 3,28 & 0,012 & 0,008 & 0,22 & 3,04 & 99,08 \\
\hline T9-am & 15,5 & 0,3 & 36,2 & 36,5 & 29,4 & 8,2 & 10,20 & 0,04 & 0,08 & 0,010 & 0.036 & 0,03 & 1,40 & 101,43 \\
\hline TS-ve & 16.5 & 0,1 & 35,2 & 35,3 & 32,3 & 7,4 & 10,58 & 0,03 & 0,07 & 0,010 & 0,014 & 0,04 & 0,55 & 102,89 \\
\hline 65-am & 14,2 & 0,6 & 41,3 & 41,9 & 36,9 & 7,2 & 0,15 & 0,06 & 0,27 & 0,009 & 0,006 & 0,07 & 0,08 & 100,84 \\
\hline $33-60$ & 3.5 & 15,0 & 3,9 & 18,9 & 2,0 & 57,9 & 4,31 & 12,70 & 0,74 & 0,052 & 0,026 & 0,35 & 0,15 & 100,63 \\
\hline $54-b r$ & 12,5 & 0,4 & 52,4 & 52,8 & 35,2 & 0,9 & 0,04 & 0,20 & 0,15 & 0,000 & 0,003 & 0,03 & 1,05 & 102,97 \\
\hline $19 i-v e$ & 9,9 & 2,7 & 48,7 & 50,8 & 18,7 & 2,4 & 0,00 & 0,02 & 17,65 & 0,048 & 0,013 & 0,11 & 0,59 & 100,24 \\
\hline$A r-x 3$ & 10,6 & 15,2 & 39,9 & 51,7 & 25,3 & 5,8 & 0,15 & $c, 30$ & 4,45 & 0,011 & 0,001 & 0,06 & 0,12 & 101,90 \\
\hline Glo4-br & 10,3 & 11,7 & 48,3 & 60,0 & 31,6 & 0,1 & 0,10 & 0,00 & 0,06 & 0,000 & 0,000 & 0,01 & 0,03 & 102,20 \\
\hline$X X Y I I-17 b r$ & 33,0 & 0,2 & 22,7 & 22,9 & 38,8 & 0,4 & 0,00 & 0,04 & 0,03 & 0,003 & 0,000 & 0,01 & 4,00 & 39,18 \\
\hline A1-ve & 2,7 & 9,5 & 77,9 & 87,4 & 4,8 & 0,6 & 0,20 & 0,01 & 5,47 & 0,024 & 0,002 & 0,04 & $i, 30$ & 102,54 \\
\hline$A i-b r$ & 35,8 & 0,2 & 10,9 & 11,1 & 30,7 & 0,3 & 0,04 & 0,01 & 0,02 & 0,003 & 0,000 & 0,04 & 21,84 & 100,79 \\
\hline
\end{tabular}

SERIE BGO

$\begin{array}{rrrrrrrrrrrrrrr}360-4 & 12,8 & 6,8 & 3,5 & 10,3 & 0,8 & 64,9 & 3,15 & 5,26 & 1,15 & 0,382 & 0,006 & 2,38 & - & 101,14 \\ 360-5 & 9,2 & 0,7 & 37,6 & 38,3 & 36,9 & 13,3 & 0,09 & 0,38 & 0,28 & 0,020 & 0,002 & 0,16 & 0,04 & 98,57 \\ 560-5 & 11,1 & 0,6 & 35,9 & 37,5 & 32,8 & 15,7 & 0,12 & 0,37 & 0,31 & 0,030 & 0,002 & 0,19 & 0,01 & 98,13 \\ 360-7 & 12,3 & 0,5 & 39,6 & 40,2 & 26,1 & 17,9 & 0,43 & 0,55 & 0,53 & 0,032 & 0,003 & 0,31 & - & 98,37 \\ 560-3 & 11,5 & 0,5 & 4,0 & 4,5 & 1,7 & 73,8 & 1,07 & 4,83 & 1,37 & 0,146 & 0,009 & 0,79 & - & 99,82 \\ 360-10 & 14,4 & - & - & 38,7 & 35,7 & 9,2 & 0,21 & 0,27 & 0,32 & 0,018 & 0,003 & 0,13 & - & 98,95 \\ 360-11 & 12,2 & 1,0 & 38,6 & 39,6 & 31,5 & 14,4 & 0,17 & 0,47 & 0,48 & 0,027 & 0,001 & 0,18 & 0,01 & 99,04 \\ 860-12 & 8,8 & 0,6 & 22,1 & 22,7 & 8,3 & 48,8 & 1,76 & 7,78 & 1,49 & 0,097 & 0,008 & 0,47 & 0,03 & 100,24 \\ 860-13 & 2,2 & 64,5 & 20,4 & 84,9 & 1,0 & 9,5 & 0,94 & 0,58 & 0,64 & 0,049 & 0,005 & 0,43 & 0,02 & 100,26\end{array}$




\title{
TECNICAS ANALITICAS
}

\author{
estā esquematizada na figura $E$. \\ A organização dos trabalhos de laboratörio \\ 1. Medida de Densidade Aparente
}

A densidade aparente foi determinada em a mostras recobertas por parafina, pesadas ao ar e dentro d'àgua, em balança analîtica, com precisão de $0,01 \mathrm{~g}$.

\section{Lâmina Delgada}

No caso de amostras friāveis, antes da laminação, foram submetidas a cozimento no bālsamo do Canadā, com a finalidade de endurecê-las.

\section{Separação Granulomētrica}

Foi realizada atravēs de um jogo de 3 :peneiras $(0,062,0,25$ e $2 \mathrm{~mm})$, sob fluxo d'ägua.

\section{Separaçäo Mineralögica}

Efetuou-se sobre amostra de granulação ade quada, pelo uso de liquidos pesados e do separador magnētico Franz. No caso de ser possível, a separação mineralö gica pôde ser feita à lupa, por catação.

5. Anälise Mineralögica

As tēcnicas utilizadas para a anälise mine 
FIGURA E

ORGANOGRAMA DOS TRABALHOS DE LABORATORIO

DURA

AMOSTRA

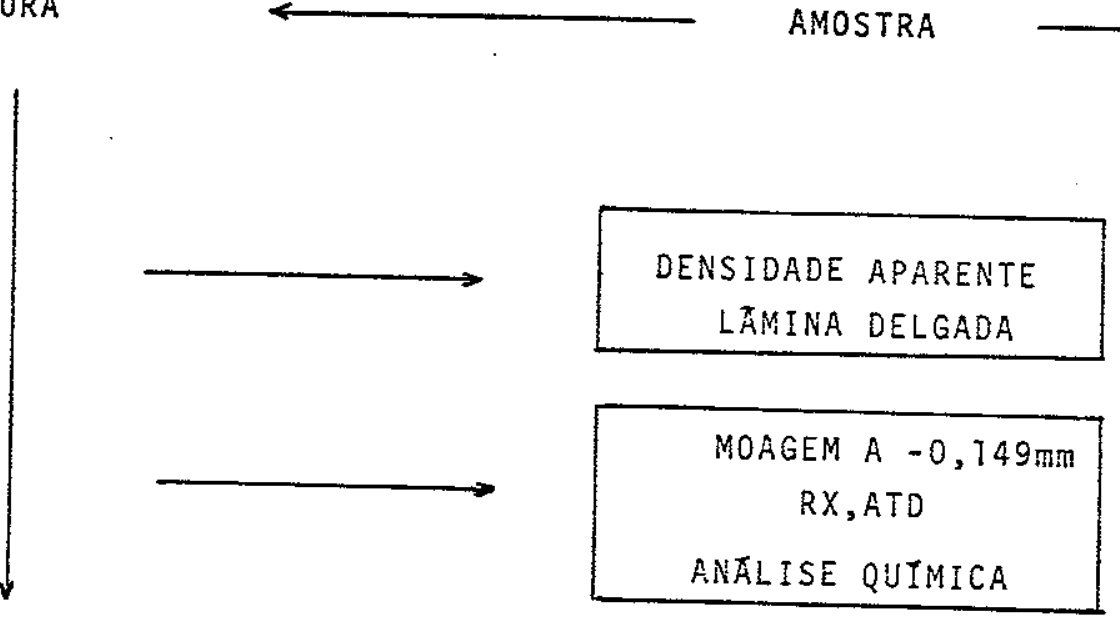

MOAGEM PARA LIBERAÇAO

DOS MINERAIS
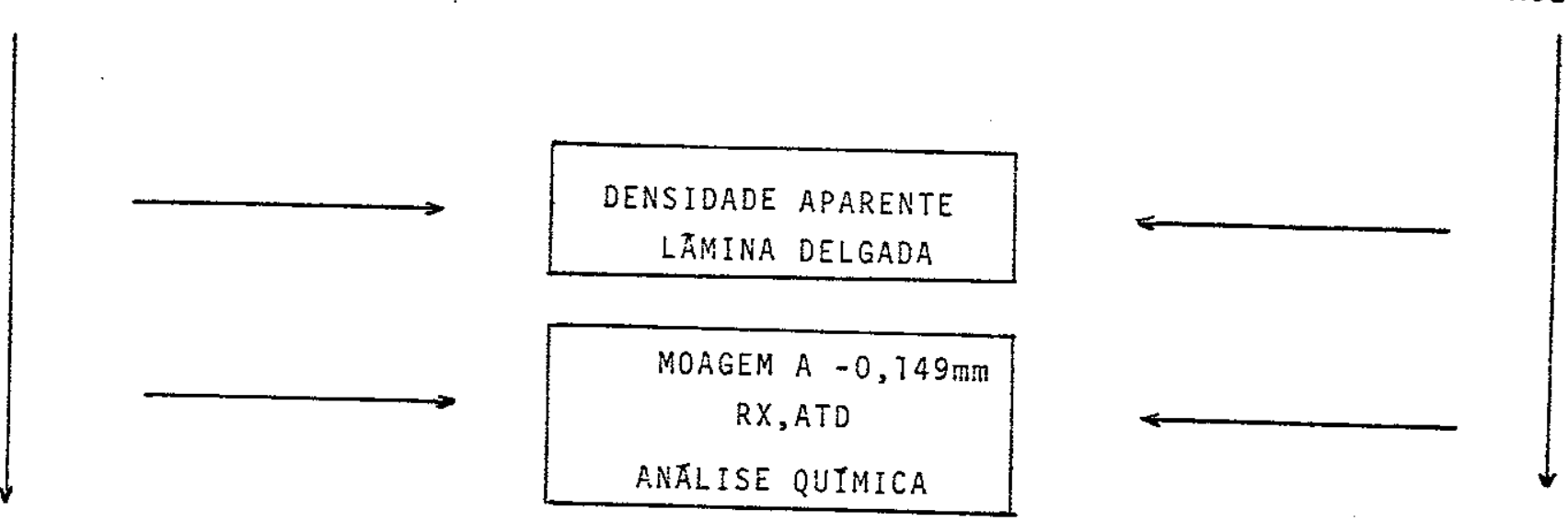

NOLE

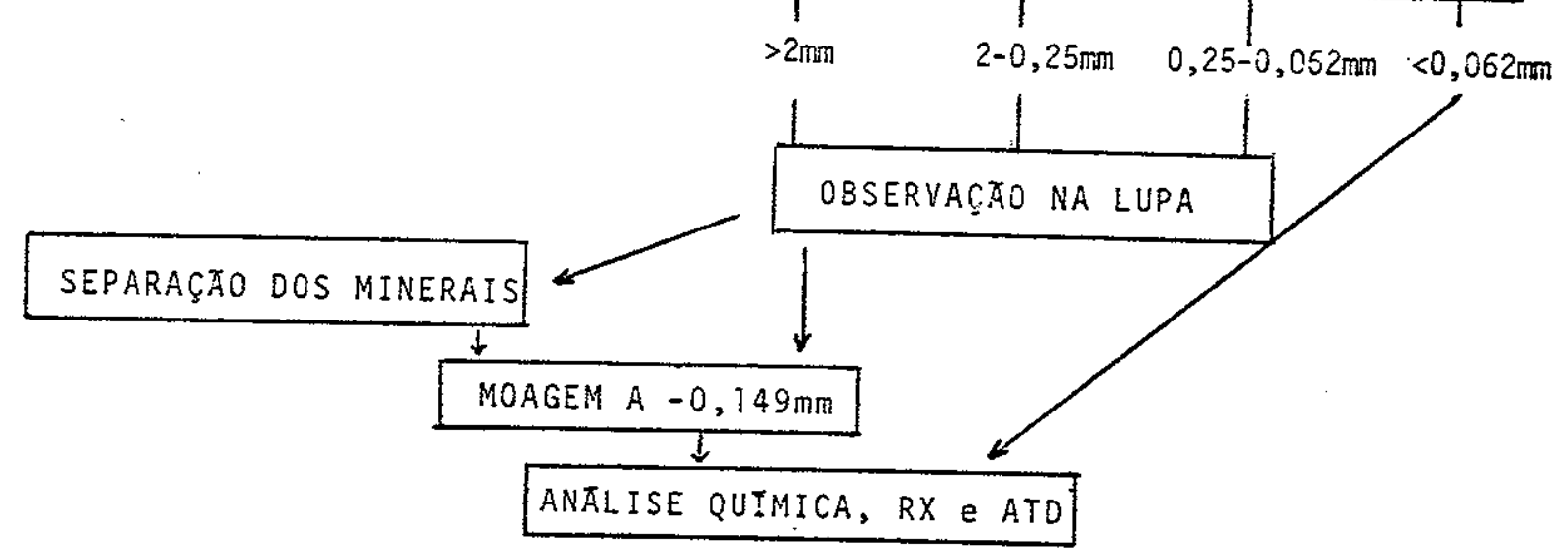


ralōgicas sao as seguintes:

a) Lupa Binocular e Microscópio Petrogrāfico

b) Anālise Tërmica Diferencial:

- velocidade de aquecimento da amostra: 200/min

- velocidade do papel: 5mm/min

Literatura consultada:Chantret et al. 1971 e Macken zie 1957.

c) Difração de Raios X:

- radiação - k $\alpha$ do Cu

- velocidade do goniōmetro- $40 / \mathrm{min}$

- velocidade do papel - $2 \mathrm{~cm} / \mathrm{min}$

Para o estudo dos filossilicatos, as amostras foram submetidas a värios tipos de tratamento prëvio:

- deferrificação (Segalen 1970)

- glicolagem

- aquecimento a $5000 \mathrm{C}$

Literatura consultada:Robert $\xi$ Tessier 1974, Lucas et al. 1959 e Brown 1961,

6. Anālise Química

a) Ataque Tota 1

Para as rochas desprovidas de piroxēnio o a taque pode ser assim esquematizado:

$\mathrm{am}+\mathrm{H}_{4} \mathrm{Cl} \mathrm{O}_{4} \longrightarrow$ solução I solução II

resĩduo II+ $\mathrm{HF}, \mathrm{HCl} \mathrm{O}_{4} \rightarrow$ solução III

solução I - dosagem de $\mathrm{Mg}, \mathrm{Fe}, \mathrm{Al}, \mathrm{Cr}, \mathrm{Ni}, \mathrm{Co}, \mathrm{Cu}, \mathrm{Mn}$ e $\mathrm{Ca}$ 
solução II - dosagem de $\mathrm{Cr}$

solução III - dosagem de $\mathrm{Mg}, \mathrm{Fe}, \mathrm{Cr}$ e $\mathrm{Ni}$

Resultados: $\mathrm{SiO}_{2}$ solüvel $=$ resīduo $\mathrm{I}$-residuo II

Quartzo=resĩduo II- Mg, Fe, $\mathrm{Cr}$ e $\mathrm{Ni}$ dosados na solução I I I

$M g=M g$ sol I $+M g$ sol III

$\mathrm{Fe}=\mathrm{Fesol} \mathrm{I}+\mathrm{Fe}$ sol III

$A]=A 1$ sol $I$

$\mathrm{Cr}=\mathrm{Cr}$ sol I+Crsol II $+\mathrm{Cr}$ sol III

$\mathrm{Ni}=\mathrm{Ni}$ sol I $+\mathrm{Ni}$ sol III

$\mathrm{CO}=\mathrm{CO}_{0}$ sol I

$\mathrm{Cu}=\mathrm{Cu}$ sol I

$M n=M n$ sol I

$\mathrm{Ca}=\mathrm{Ca}$ sol I

No caso de amostras portadoras de piroxênio, passa-se diretamente à fluorização:

$\mathrm{am}+\mathrm{HF}, \mathrm{HCl} \mathrm{O}_{4} \rightarrow$ solução I

sados na soluçäo I.

$0 \mathrm{Mg}, \mathrm{Fe}, \mathrm{Al}, \mathrm{Cr}, \mathrm{Ni}, \mathrm{Co}, \mathrm{Cu}, \mathrm{Mn}$ e Ca säo do

O Si $\overline{\mathrm{e}}$ dosado numa alîquota à parte:

$\mathrm{am}+\mathrm{Na}_{2} \mathrm{CO}_{3} \frac{9000 \mathrm{C}}{\Delta}$ fusão $+\mathrm{HCl}+\mathrm{HClO}_{4} \longrightarrow$ solução

0 peso do residuo I e o peso da silica conti da .

b) Ataque Parcial

Fazem-se ataques parciais com a finalidade 
de determinar a quantidade e a composiçäo de materiais amor fos ou criptocristalinos (Segalen 1968). 0 esquema geral $\overline{\bar{e}}$ o seguinte:

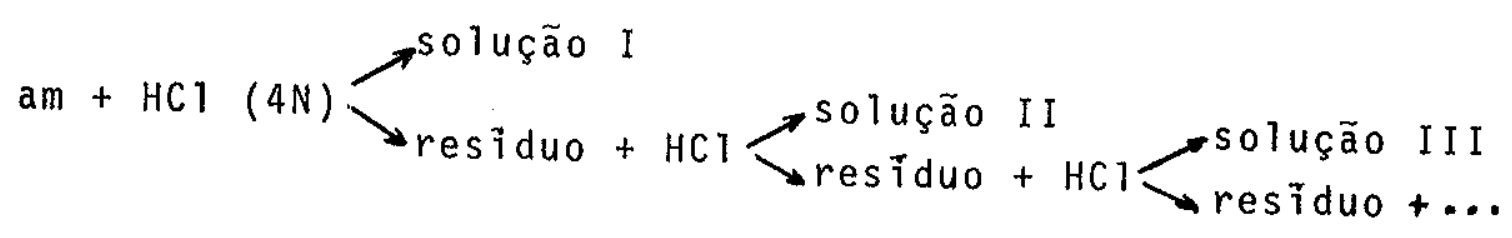

Foram dosados o $\mathrm{Mg}$, Si e Fe em 8 soluções ob tidas: segundo o esquema acima. A curva acumulada dos produtos extraĩdos permite avaliar a cinētica da extraçäo, e sua forma depende do grau de cristalinidade do material. As sim, curvas de extração retilinneas refletem boa cristalinidade, isto $\vec{e}$, o elemento extraijo provëm do reticulo crista 1 ino dos minerais. Quando hä produtos amorfos ou criptocris talinos, a curva de extração ē inicialmente cōncava em relá ção a abscissa. E possivel avaliar a quantidade do elemento em estado amorfo ou criptocristalino extrapolando o segmento retilinio da curva até a intersecção com o eixo das orde nadas.

c) Dosagem

A perda ao fogo foi dosada em uma aliquota seca a $1050 \mathrm{C}$ e, posteriormente queimada a $9000 \mathrm{C}$.

$0 \mathrm{Mg}, \mathrm{Fe}, \mathrm{Al}, \mathrm{Cr}, \mathrm{Ni}, \mathrm{Co}, \mathrm{Cu}, \mathrm{Mn}$ e $\mathrm{Ca}$ foram dosados em solução, no espectrofotömetro de absorçăo atômica marca Varian Techtron (modelo 1250). Os parämetros utili zados para cada elemento constam da tabela que se segue.

Os padrões utilizados foram 2 soluções- mãe de composiçoes semelhantes a soluçöes de rocha pouco altera da e de laterita. A partir dessas soluções-mãe obtiveram-sé os padrões nas diluições adequadas. 
PARAMETROS UTILIZADOS NAS MEDIDAS REALIZADAS NO ESPECTROFOTŌMETRO DE ABSORÇAO ATŌMICA

$\begin{array}{llrl} & \text { Chama } & \text { Comprimento de onda }(\mathrm{nm}) & \text { Faixa de Concentração } \\ \mathrm{Mg} & \text { oxidante } & 285,2 & 0,1-0,4 \\ \mathrm{Fe} & \text { oxidante } & 248,3 & 2,5-10 \\ \mathrm{Al} & \text { redutora } & 309,3 & 40-200 \\ \mathrm{Cr} & \text { redutora } & 357,9 & 2-8 \\ \mathrm{Ni} & \text { oxidante } & 232,0 & 3-12 \\ \mathrm{Co} & \text { oxidante } & 240,7 & 3-12 \\ \mathrm{Cu} & \text { oxidante } & 324,7 & 2-8 \\ \mathrm{Mn} & \text { oxidante } & 279,5 & 1-4 \\ \mathrm{Ca} & \text { (emissão) } & 422,7 & 1-4\end{array}$


DOCUMENTAÇAO FOTOGRAF ICA 
Foto 1 - Visão geral do maciço ultrabäsico.

Foto 2 - Serra do Tira-Pressa, intensamente silicificada.

Foto 3 - Olivina ocupando o centro reticulado de serpentina. Veio de carbonato. Nicōis cruzados. Aumen to aproximado: 110 vezes. 


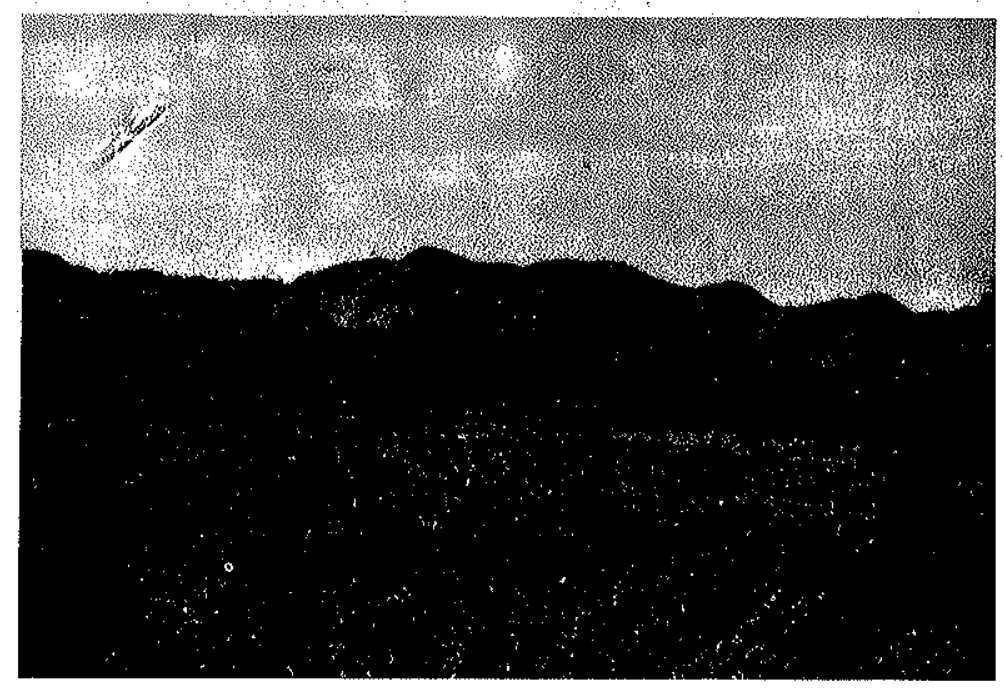

FOTO I

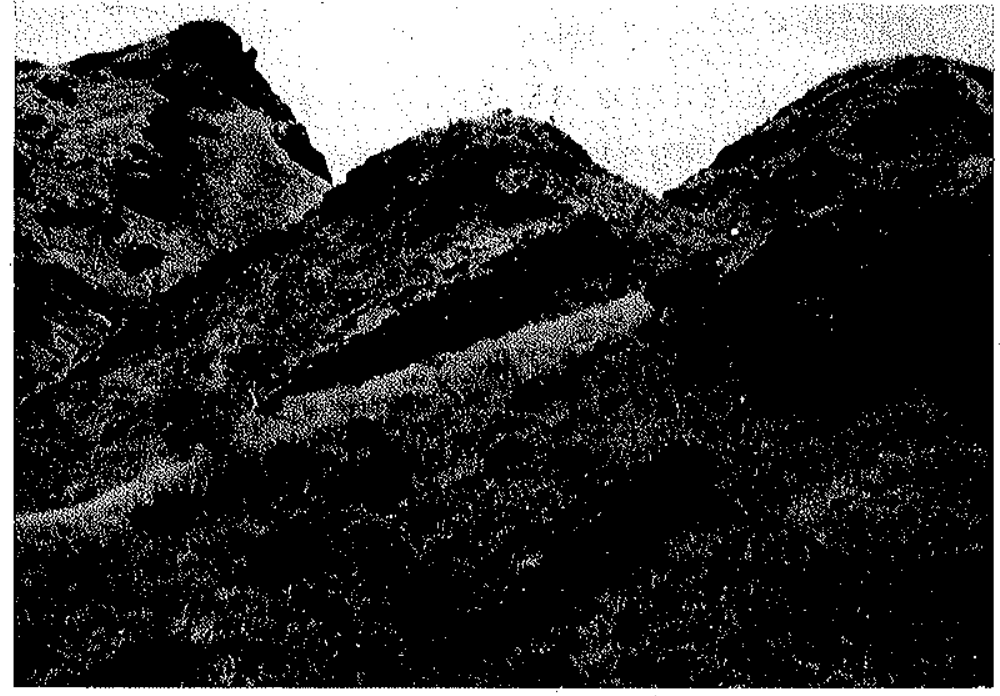

FOTO 2

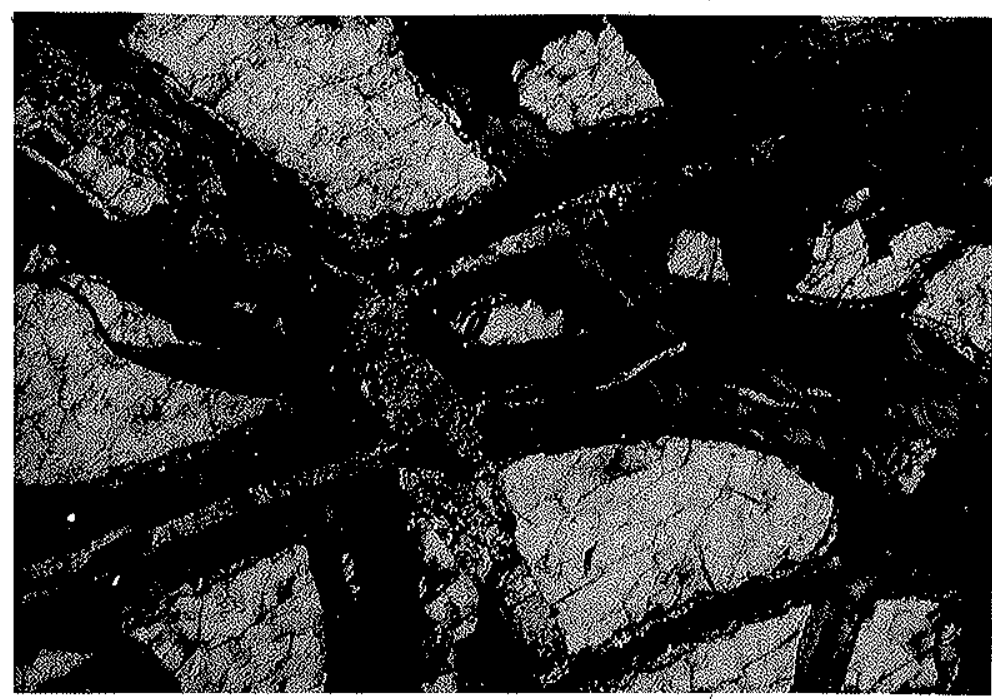

FOTO 3 
Foto 4 - Cristais de cromita circundados por vermiculitaclorita. Nicóis cruzados. Aumento aproximado: 90 vezes.

Foto 5 - Magnetita entre as bandas de serpentina. Nicöis paralelos. Aumento aproximado: 90 vezes.

Foto 6 - Veio de quartzo, mais bem cristalizado quando livre de Fe. Nicóis cruzados. Aumento aproximado: 110 vezes. 


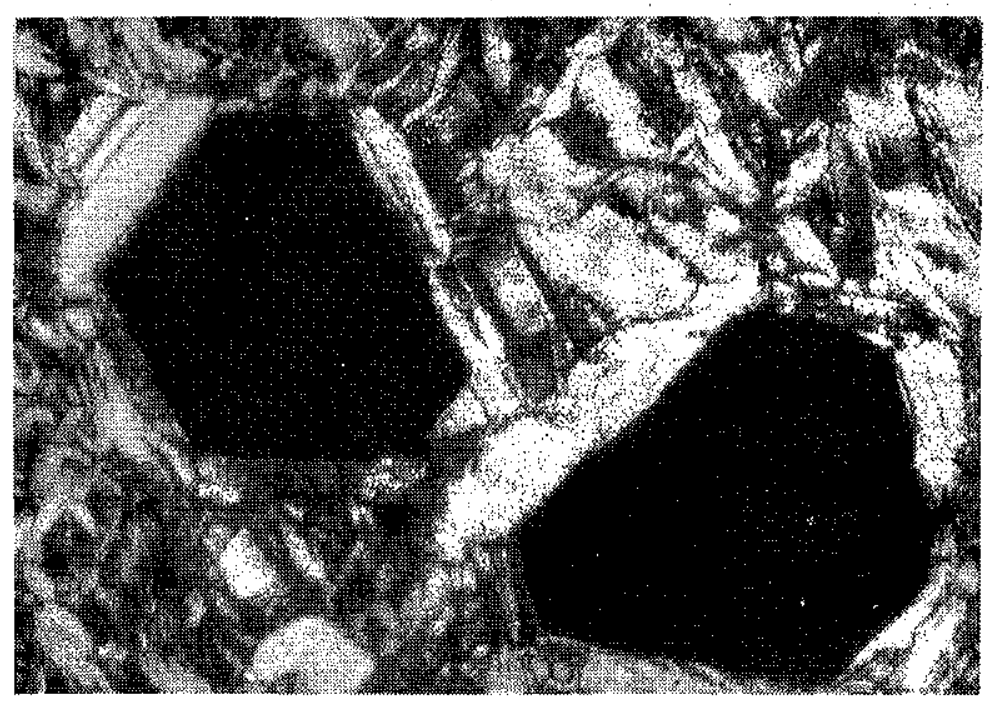

FOTO 4

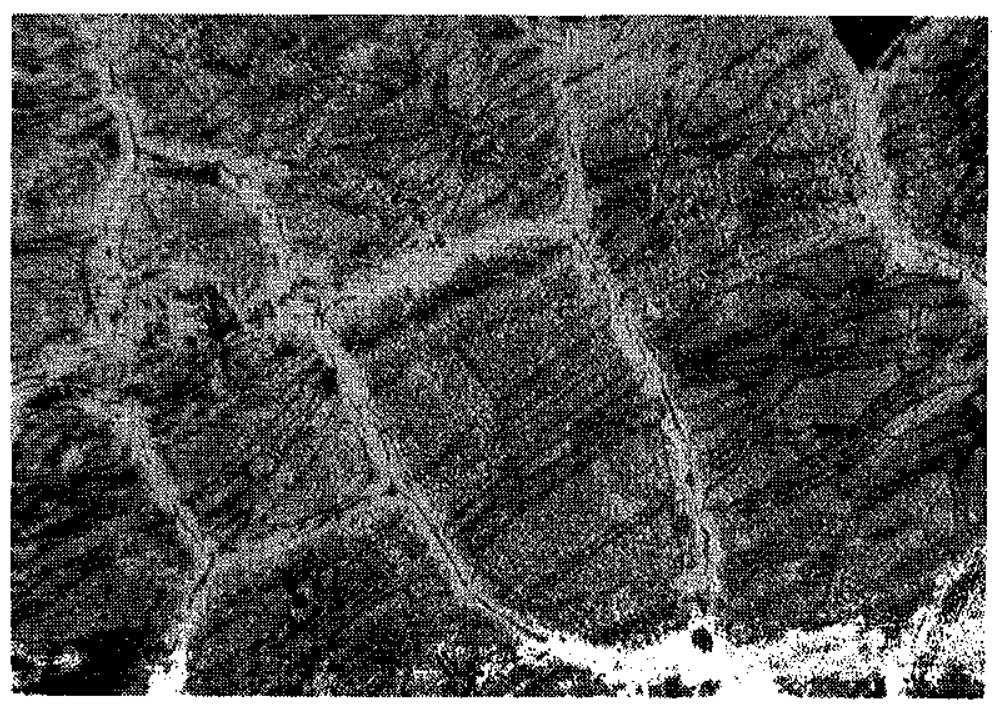

FOTO 5

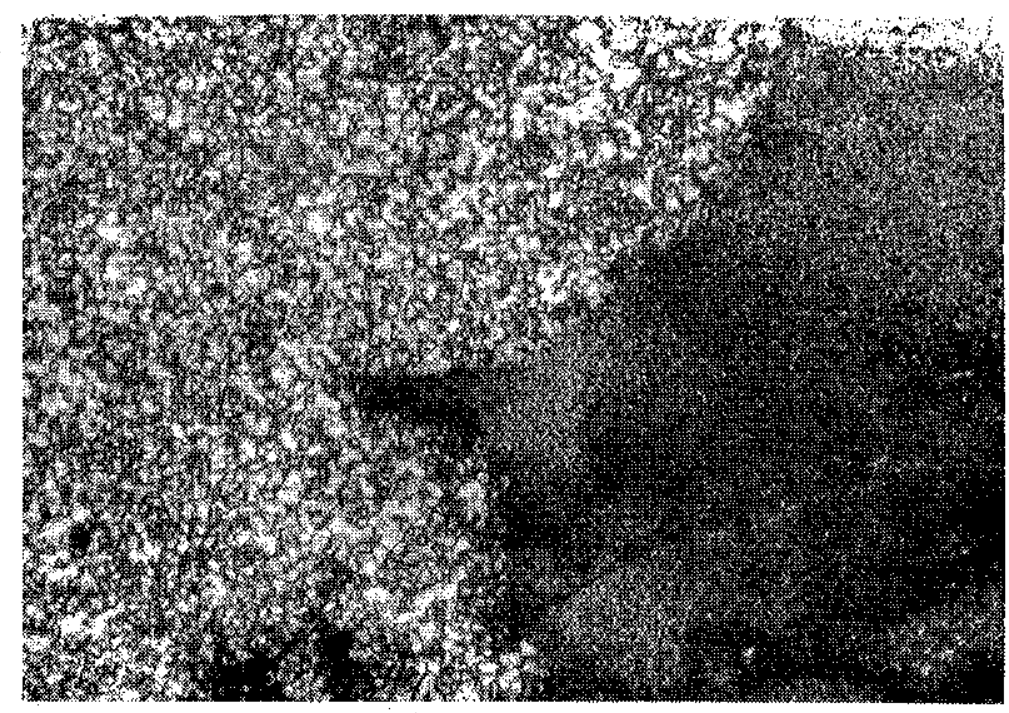

FOTO 6 
Foto 8 - Serpentina placōide (II), ocupando o centro do re ticulo. Fe depositado no contato da serpentina I e da serpentina II. Nícōis cruzados. Aumento apro ximado: 220 vezes.

Foto 7 - Fantasma de olivina, preenchido por quartzo microcristalino. Nicóis cruzados. Aumento aproximado: 90 vezes.

Foto 9 - Fantasma de olivina, preenchido por amorfos ferru ginosos. Nicōis cruzados. Aumento aproximado: $11 \overline{0}$ vezes. 


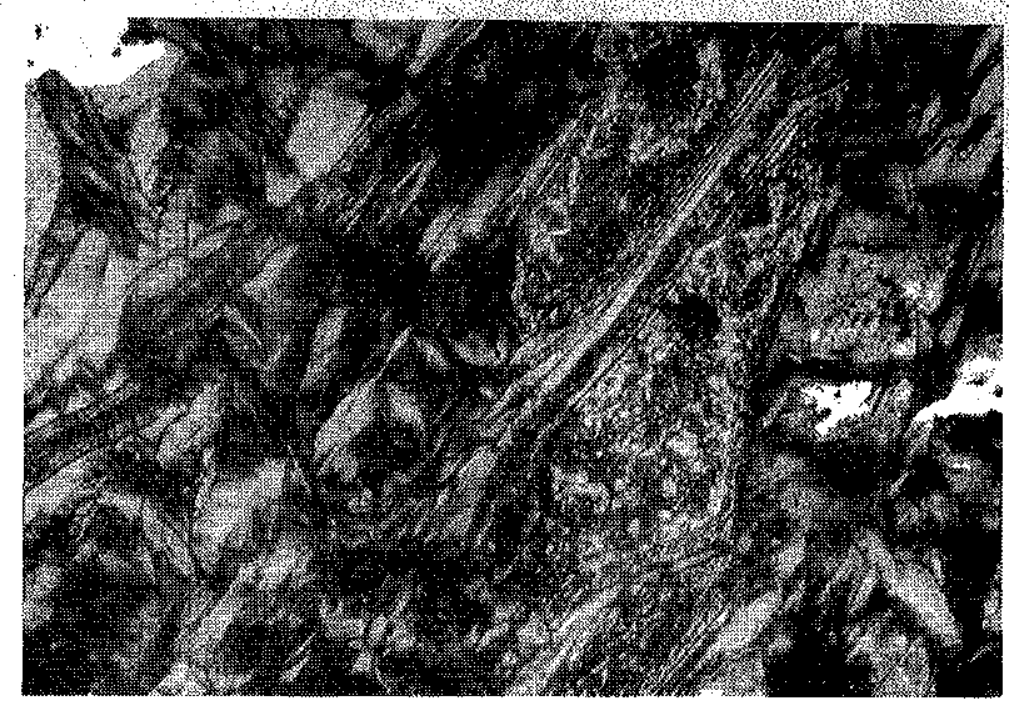

FOTO 7

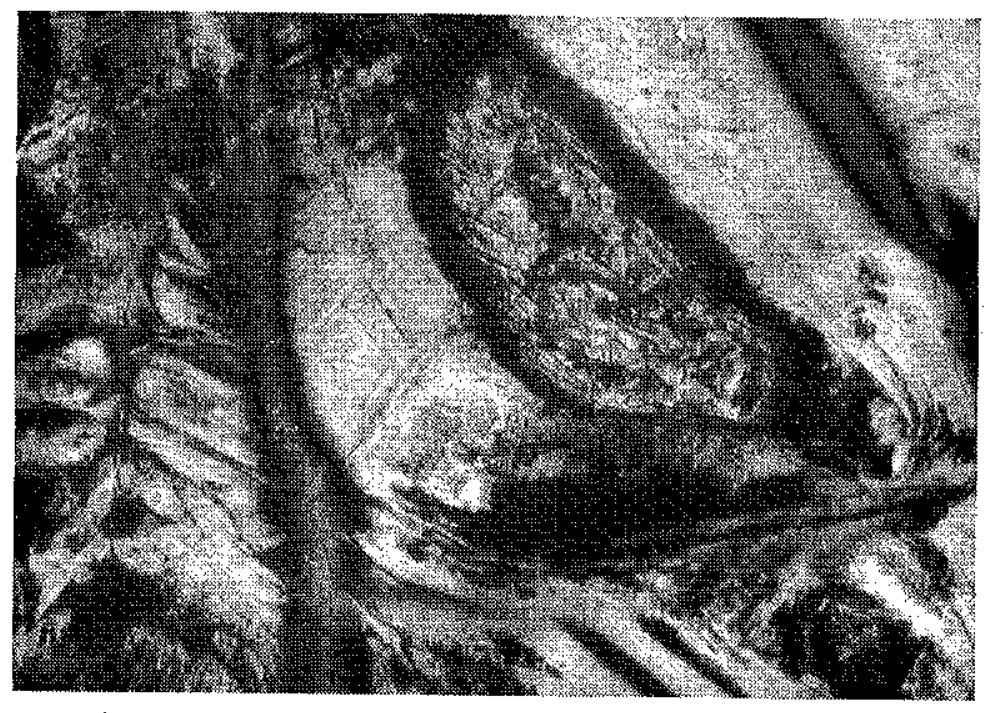

FOTO 8

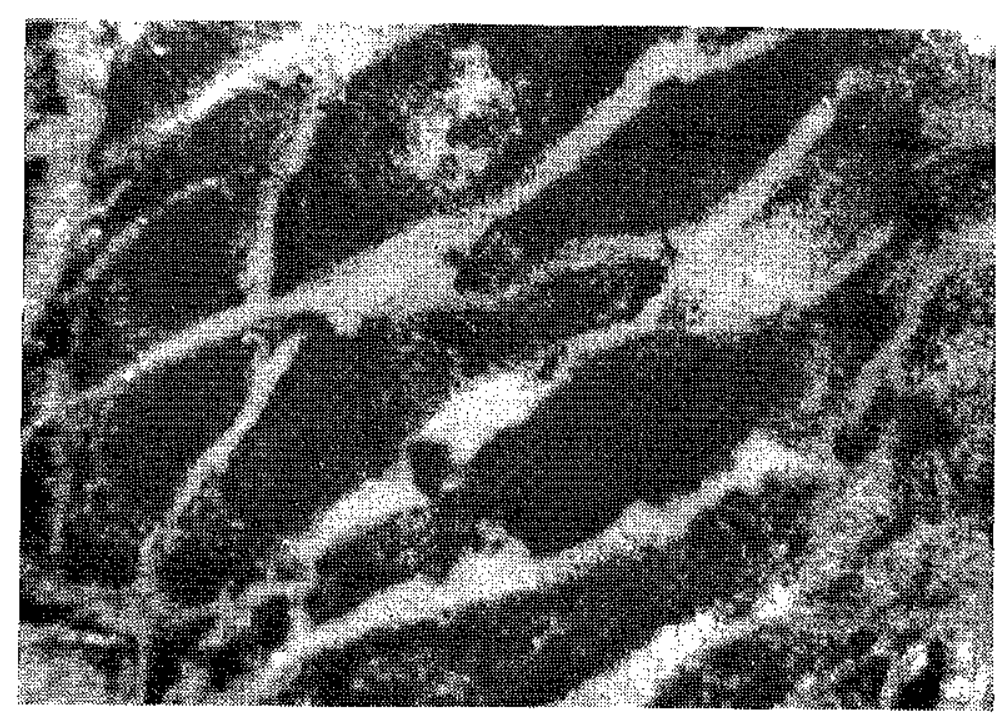

FOTO 9 